Universidade de São Paulo

Faculdade de Arquitetura e Urbanismo

Programa de Pós-graduação em Arquitetura e Urbanismo

Área de Concentração: Paisagem e Ambiente

\title{
ALTO E MÉDIO SAPUCAÍ: CENÁRIOS PARA O PLANEJAMENTO AMBIENTAL
}

\author{
Helena Mendonça Faria
}

Tese apresentada à Faculdade de Arquitetura e Urbanismo da Universidade de São Paulo (FAU-USP) para a obtenção do título de Doutor em Arquitetura e Urbanismo.

Orientadora: Profa. Dra. Maria Assunção Ribeiro Franco.

São Paulo, outubro de 2007. 
AUTORIZO A REPRODUÇÃO E DIVULGAÇÃO TOTAL OU PARCIAL DESTE TRABALHO, POR QUALQUER MEIO CONVENCIONAL OU ELETRÔNICO, PARA FINS DE ESTUDO E PESQUISA, DESDE QUE CITADA A FONTE.

ASSINATURA:

E-MAIL:fm_helena@yahoo.com.br

\section{Faria, Helena Mendonça}

F224a Alto e Médio Sapucaí: cenários para o planejamento ambiental / Helena Mendonça Faria. - - São Paulo, 2007. 203 p. : il.

Tese (Doutorado - Área de Concentração: Paisagem e Ambiente) - Faculdade de Arquitetura e Urbanismo da Universidade de São Paulo.

Orientadora: Maria Assunção Ribeiro Franco.

1.Planejamento ambiental 2.Bacia hidrográfica 3.Rio Sapucaí (MG) 4. Desenvolvimento sustentável 5.Turismo I.Título 
Para minha mãe Victoria (in memorian), que sempre esteve ao meu lado e que de certa forma ainda está. 


\section{AGRADECIMENTOS}

A lista de agradecimentos seria imensa se fosse pensar em todos que de alguma forma contribuíram para este trabalho. Quero agradecer a todos que passaram ou estão passando pela minha vida e que de alguma forma também são responsáveis pela conclusão deste trabalho. Vou começar então de dentro para fora, daqueles que dividem os dias comigo, que estão mais presentes.

Agradeço todo apoio que tive de minha mãe, seja através de incentivos, ou de ações, que não têm preço, e não têm fim. Serei eternamente grata. Agradeço a meu pai (in memorian) pelo despertar que me trouxe à vida de pesquisadora. Agradeço minha irmã Izabel, o apoio, as observações como socióloga, e a certeza de contar com toda sua dedicação, amor, carinho e atenção, sempre. Agradeço a meu companheiro Paulo Vinícius pelo carinho, paciência e compreensão, e pelo bom humor que trouxe para minha vida e para este trabalho. Agradeço a Elaine Cristina que além de cunhada querida ajudou muito com mapas e diagramações do trabalho e ao Henrique, meu irmão que sempre traz algo novo para minha vida. Agradeço a tia Bel por sempre estar do nosso lado.

Agradeço toda a atenção, as observações, idéias, pensamentos e incentivos da Professora Maria Assunção Ribeiro Franco, que mesmo antes de conhecer já me inspirava na produção deste trabalho. Agradeço sua amizade e apoio em horas difíceis, mesmo em um mundo sem tempo e espaço para conversas e devaneios.

Agradeço imensamente ao Professor Dr. Paulo Renato Mesquita Pellegrino pelas observações extremamente importantes na banca de qualificação e também por me inspirar com suas idéias a respeito da paisagem e do ambiente. Agradeço 
também à Profa $^{\mathrm{a}} \mathrm{Dr}^{\mathrm{a}}$ Cíntia Maria Afonso pelas observações, comentários e incentivos a conclusão deste trabalho.

Agradeço a todos os funcionários da Pós-Graduação da FAU-USP, às bibliotecárias, e aos professores com os quais gostaria de ter aproveitado mais tempo, especialmente aqueles com os quais pude conviver em disciplinas: Catharina Pinheiro Cordeiro dos Santos Lima, Maria Ângela Faggim Pereira Leite, Júlio Katinsky, Mario Henrique Simão D’ Agostino e Luiz Américo de Souza Munari.

Sou muito grata também aos colegas da FAU-USP que permitiram a troca de experiências e a solução de dúvidas no decorrer desta pesquisa.

Agradeço aos amigos queridos Fernando, Cristiane, Cléo, José Paulo e Ricardo, que sempre me ouviram e apoiaram. Ao imenso apoio da Armelinda e do Carlos Gomes, e de tantos outros amigos de caminhada.

Agradeço a meus alunos do curso de Geografia e Meio Ambiente da Fundação de Ensino e Pesquisa de Itajubá, em especial à Fernanda. Também aos meus orientandos de iniciação científica, que sem imaginar contribuíram para as questões desenvolvidas neste trabalho. Aos meus colegas de trabalho, em especial a Liane Pinheiro com quem me identifico na vida de pesquisadora. Enfim, agradeço a imensa energia criadora para qual existem vários nomes e crenças. E também agradeço a terra de encantamentos e descobertas formadas pelas florestas, rios, cidades e pessoas de Minas Gerais. 


\section{RESUMO}

O estudo das características da Bacia Hidrográfica do Sapucaí em Minas Gerais permitiu compreender que esta região rica em potencial humano e natural deve ser tratada como uma região estratégica, por seu potencial hídrico e paisagístico, por sua riqueza cultural e por sua proximidade às regiões metropolitanas mais significativas do país. Entretanto o modelo de desenvolvimento adotado não tem privilegiado o potencial existente de maneira satisfatória em planos e programas que efetivamente se tornem realidade. Partindo-se de uma discussão ampla da questão ambiental e do papel real e imaginado para o planejamento ambiental, urbano e regional buscou-se um entendimento de quais seriam os caminhos de desenvolvimento mais indicados para a região estudada, entendendo que, neste caso, são pressupostos primordiais a valorização da paisagem, da cultura e do desenvolvimento humano.

\section{Assunto: Planejamento da Paisagem, Planejamento Ambiental}

Palavras-Chave: Ambiente, Planejamento Ambiental, Bacias Hidrográficas, Desenvolvimento Regional, Sustentabilidade, Rio Sapucaí, Turismo. Caminhos Cênicos. Cenários Ambientais. 


\section{ABSTRACT}

The application about the characteristics of Sapucai's Hydrographic Basin, in Minas Gerais permitted to understand that this region, rich in human potential and natural, must be viewed as strategic, for his hydro and landscape potential, for his cultural riches and for his proximity of the most metropolitan regions of the country. However, the development model used didn't favored the existed potential in a satisfactory manner into projects and programs that effectively made them real. Starting from a discussion about the environmental subject and the real and imagined role for the urban, regional and environmental planning we have looked for an agreement of what would be the most indicated ways of development, understanding that, in this case, the valorization of the landscape, the culture and the human development are prime assumed.

Subject: Landscape planning, Environmental planning.

Key Words: Environment, Environmental Planning, Hydro graphics Basin, Regional Development, Sustainability, Sapucai River, Parkways, Environmental Scenery. 


\section{SUMÁRIO}

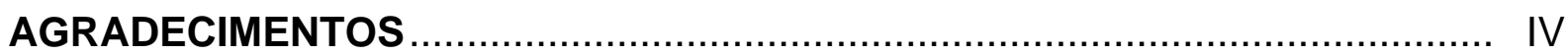

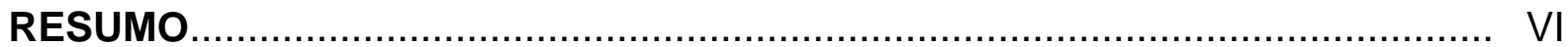

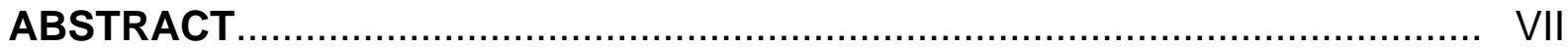

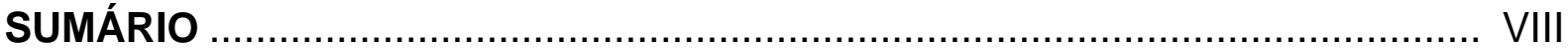

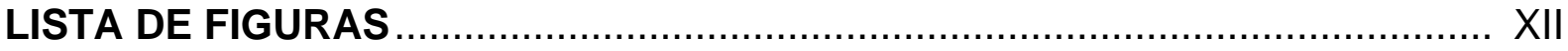

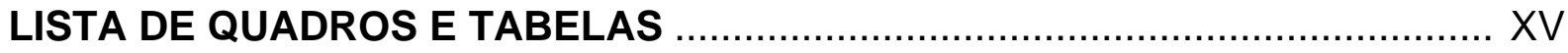

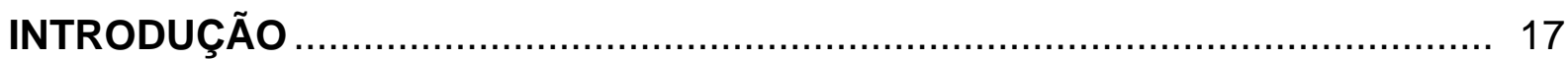

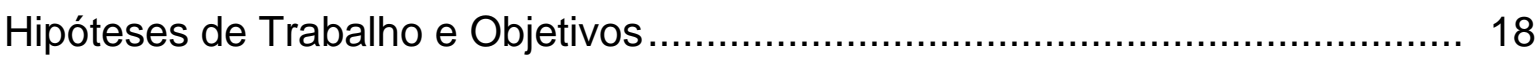

\section{PARTE I}

FUNDAMENTAÇÃO TEÓRICA E METODOLÓGICA ................................. 21

CAPÍTULO 1

AMBIENTE E PAISAGEM: ORIGEM E CONCEITOS CONTEMPORÂNEOS ....... 22

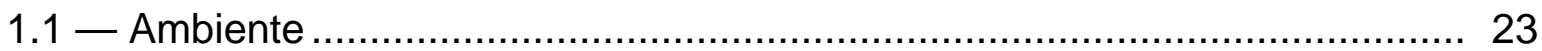

1.1.1 - Conceituação de Meio Ambiente e as evidências das ciências físicas e biológicas........................................... 25

1.1.2 - Conceituação de Ambiente segundo perspectivas da crítica ao modelo capitalista de desenvolvimento ............................. 27

1.1.3 - Conceituação de Ambiente em uma perspectiva histórica ............... 30

1.1.4 - Antropocentrismo e Biocentrismo ......................................... 33

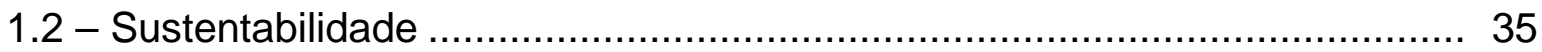

1.2.1 — Os impasses da Sustentabilidade.......................................... 36

1.2.2 - Propostas de solução para os impasses da Sustentabilidade........... 40

1.3 - Paisagem, Urbanismo e a Idéia de Ambiente ................................. 42

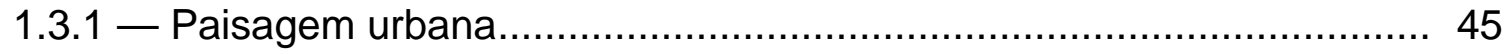

1.4 - Turismo e Cultura como Fator Indutor de Sustentabilidade .................. 48 
1.5 - Ambiente, Paisagem e Sustentabilidade na

Bacia Hidrográfica do Sapucaí

FUNDAMENTAÇÃO METODOLÓGICA

\section{CAPÍTULO 2}

PLANEJAMENTO AMBIENTAL: CONCEITOS E MÉTODOS.

2.1 — Cidade e Planejamento Ambiental ........................................ 54

2.2 — Planejamento e Gestão Ambiental ................................................. 61

2.3 - A Bacia Hidrográfica, a Cidade e as Unidades de

Conservação: Espaço e Tempo no Planejamento Ambiental .................. 63

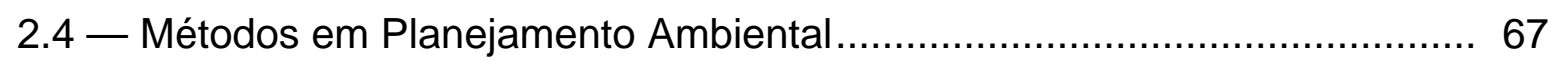

2.5 - Metodologia de Criação de Cenários Ambientais ............................. 71

\section{PARTE II}

MONTANHAS E VALE: A SUSTENTABILIDADE NA

BACIA HIDROGRÁFICA DO SAPUCAÍ.

\section{CAPÍTULO 3}

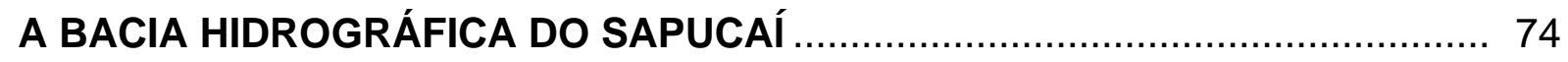

3.1 - Caracterização da Bacia Hidrográfica: o Alto e Médio Sapucaí ............... 76

3.1.1 - Impactos Ambientais ao longo da Bacia Hidrográfica do Sapucaí: equilíbrio ambiental ameaçado

3.1.1.1 - Vegetação e Fauna: a Sapucaia que deu origem ao nome do rio não existe mais em suas margens

3.1.2 - Gestão da Bacia Hidrográfica no Alto e Médio Sapucaí a partir da legislação referente aos recursos hídricos existentes.

3.1.3 - História

3.2 - Áreas protegidas na Serra da Mantiqueira e Alto Sapucaí. 94

3.2.1 - A Serra da Mantiqueira 95

3.2.2 - Relevo, Clima e Vegetação na Mantiqueira e no Alto Sapucaí 97

3.2.3 - Breve História da ocupação e dos caminhos da Mantiqueira 101 
3.2.3.1 - Mantiqueira: dos Sertões proibidos à industrialização 104

3.2.4 - A APA da Serra da Mantiqueira 107

3.3 - Breve caracterização social e econômica da região do Alto e Médio Sapucaí

3.3.1 - O Alto Sapucaí e a APA da Serra da Mantiqueira 112

3.3.2 - O Médio Sapucaí: crescimento econômico e urbano 120

3.3.2.1 - Crescimento Urbano e Qualidade de Vida no vale do Sapucaí.. 125

3.3.2.2 - Potencial Econômico e riscos de impactos ambientais crescentes ao longo do Vale do Sapucaí 129

\section{CAPÍTULO 4}

OS CIRCUITOS TURÍSTICOS COMO PROJETOS DE DESENVOLVIMENTO PARA O ALTO E MÉDIO SAPUCAÍ. 130

4.1 - História, Cultura e Preservação Ambiental no Alto e Médio Sapucaí 130

4.1.1 - Referências históricas de Minas Gerais, da Estrada Real e da Região do Alto e Médio Sapucaí.

4.1.1.1 - Estrada Real 131

4.2 - Circuitos Turísticos ao longo da Estrada Real e na Região do Alto e Médio Sapucaí.

4.2.1 - Circuitos turísticos no Caminho Velho da Estrada Real: intersecções com a região do Alto e Médio Sapucaí.

4.3 - Observações sobre pontos percorridos no

Caminho Velho da Estrada Real.

4.3.1 - Referências Históricas, Culturais e Paisagísticas do

Trajeto A — Itajubá-Cunha.

4.3.2 - Referências Históricas, Culturais e Paisagísticas do Trajeto B — Itajubá-Caxambú . 149

4.3.3 - Considerações sobre as condições de desenvolvimento dos pontos percorridos no Caminho Velho da Estrada Real 166 
4.4 - Considerações sobre possibilidades de desenvolvimento da atividade turística no Alto e Médio Sapucaí: Circuito Terras Altas da Mantiqueira e Circuito Caminhos do Sul de Minas

\section{PARTE 3}

CENÁRIOS AMBIENTAIS PARA O ALTO E MÉDIO SAPUCAÍ 175

\section{CAPÍTULO 5}

\section{CENÁRIOS DO PLANEJAMENTO AMBIENTAL NA}

BACIA HIDROGRÁFICA DO SAPUCAÍ.

5.1 - Integração do Alto e Médio Sapucaí através do planejamento e da gestão ambiental.

5.2 - Criação de cenários ambientais para o Alto e Médio Sapucaí. 179

5.2.1 - Cenário de conservação ambiental para o Alto e Médio Sapucaí . 182

5.2.2 - Cenário de desenvolvimento do Ecoturismo e do turismo cultural no Alto e Médio Sapucaí 185

5.2.3 - Cenário de desenvolvimento de Pólos Tecnológicos 188

5.2.4 - Cenário de desenvolvimento sustentável . 191

\section{PARTE 4}

CONCLUSÃO E BIBLIOGRAFIA 194

CONCLUSÃO 195

REFERÊNCIAS BIBLIOGRÁFICAS. 196 


\section{LISTA DE FIGURAS}

Figura 1: Interações entre planejamento e gerenciamento ambiental 63

Figura 2: Localização dos municípios da Bacia Hidrográfica do Rio Sapucaí no contexto do sudeste brasileiro 80

Figura 3: Municípios da Bacia Hidrográfica do Sapucaí 81

Figura 4: Drenagem da Bacia Hidrográfica do Alto e Médio Sapucaí 82

Figura 5: Paisagem típica do Alto Sapucaí (Vista da Estrada Delfim Moreira para Marmelópolis) 83

Figura 6: Paisagem típica do Médio Sapucaí (Rio Sapucaí em Piranguinho) 84

Figura 7: Bacia do Rio Grande: qualidade das águas em 2006 85

Figura 8: Itajubá-MG e o Rio Sapucaí 86

Figura 9: Trecho do Rio Sapucaí em Itajubá, 2001. Antes de intervenção de alargamento 86

Figura 10: Intervenção no Rio Sapucaí em Itajubá-MG realizada em 2001 após uma grande enchente no ano de 2000 87

Figura 11: Vista da Cidade de Virgínia 87

Figura 12: Sapucaia, planta que deu origem ao nome do Rio Sapucaí 89

Figura 13: Trecho do Rio Sapucaí com mata ciliar entre Piranguinho e Santa Rita do Sapucaí 90

Figura 14: Mata ciliar na área urbana de Itajubá no ano de 2001 sendo derrubada pela intervenção de alargamento da calha principal do Rio 90

Figura 15: Represa de Furnas 94

Figura 16: Imagem de satélite da Serra da Mantiqueira e contorno da APA 96

Figura 17: Imagem de satélite da Serra da Mantiqueira em perspectiva 96

Figura 18: Mata com Araucária na APA da Serra da Mantiqueira,

no município de Marmelópolis 100

Figura 19: Vista do Pico dos Marins na APA da Serra da Mantiqueira 100

Figura 20: Mapa da Estrada Real 103 
Figura 21: Localização da APA da Serra da Mantiqueira 110

Figura 22: Mapa dos Municípios da APA da Serra da Mantiqueira

Figura 23: Porcentagem de população rural (1991/2000) nos municípios da APA da Serra da Mantiqueira e da Bacia Hidrográfica do Alto Sapucaí

Figura 24: Índice de Desenvolvimento Humano Municipal, 2000, nos municípios da APA da Serra da Mantiqueira

Figura 25: Remanescentes Florestais na APA Serra da Mantiqueira 118

Figura 26: Cidade de Delfim Moreira na APA da Serra da Mantiqueira 118

Figura 27: Propriedade Rural em Delfim Moreira 119

Figura 28: Cidade de Marmelópolis na APA da Serra da Mantiqueira 119

Figura 29: Cidade de Virgínia na APA da Serra da Mantiqueira 120

Figura 30: Rede Viária na Região do Alto e Médio Sapucaí 122

Figura 31: Cidade de Santa Rita do Sapucaí 128

Figura 32: Ocupação na área central de Itajubá: extrema proximidade com o Rio Sapucaí 128

Figura 33: Mapa Estrada Real, Rios e Estradas 135

Figura 34: Mapa de todos os Circuitos Turísticos do Caminho Velho percorrido .. 140

Figura 35: Mapa do Trajeto A: Itajubá-Cunha 146

Figura 36: Túnel do Barreirinho em Delfim Moreira-MG construção da década de 1920, em estilo eclético, que fazia parte do antigo ramal da rede mineira de viação

Figura 37: Trecho entre Guaratinguetá-SP e Cunha-SP, visão da Serra da Bocaina ao fundo

Figura 38: Igreja Matriz Nossa Senhora da Conceição, na praça central de Cunha-SP, construída em 1731 é um exemplo do barroco paulista 148

Figura 39: Cachoeira do Desterro, Cunha-SP 148

Figura 40: Mapa do Trajeto B — Itajubá-Caxambu 161

Figura 41: Vista parcial de Pedralva-MG 162

Figura 42: Trecho entre a cidade de Pedralva e São Lourenço 162 
Figura 43: Vista do Parque das Águas em São Lourenço 162

Figura 44: Parque das Águas em Caxambu-MG 163

Figura 45: Cachoeira do Lambari em Cristina-MG 163

Figura 46: Igreja Divino Espírito Santo em Cristina-MG 164

Figura 47: Igreja Matriz Nossa Senhora de Lourdes em Maria da Fé-MG 164

Figura 48: Cachoeira do Zé Braga em Maria da Fé 165

Figura 49: Oficina Gente de Fibra em Maria da Fé 165

Figura 50: Entrada da Estrada da Serra dos Toledos, onde se localiza a Reserva Biológica da Serra dos Toledos, em Itajubá 166

Figura 51: Estrada da Serra dos Toledos, onde se localiza a

Reserva Biológica da Serra dos Toledos, em Itajubá 169

Figura 52: Observatório Nacional de Astrofísica em Brasópolis 169

Figura 53: Vista de Itajubá 170

Figura 54: Antiga Estação Ferroviária de Maria da Fé-MG 170

Figura 55: Vista de Delfim Moreira 171

Figura 56: Vista de área rural em Delfim Moreira 171

Figura 57: Vista da cidade de Marmelópolis 172

Figura 58: Placa do Circuito Estrada Real na cidade de Virgínia 172

Figura 59: Vista da cidade de Virgínia 173

Figura 60: Diagrama de Criação de Cenários Ambientais para a

Sustentabilidade na Bacia Hidrográfica do Sapucaí . Erro! Indicador não definido.

Figura 61: Cenário de Conservação Ambiental para o Alto e Médio Sapucaí ... Erro! Indicador não definido.

Figura 62: Cenário de Desenvolvimento do Ecoturismo e do turismo cultural ...... 187

Figura 63: Cenário de desenvolvimento de Pólos Tecnológicos ......................... 190

Figura 64: Cenário de desenvolvimento Sustentável ....................................... 193 


\section{LISTA DE QUADROS E TABELAS}

Tabela 1: Municípios da região da Bacia Hidrográfica do Alto e Médio Sapucaí ... 79

Tabela 2: População nos municípios da APA da Serra da Mantiqueira e na Bacia Hidrográfica do Alto Sapucaí

Tabela 3: Porcentagem de população rural (1991/2000) nos municípios da APA da Serra da Mantiqueira e da Bacia Hidrográfica do Alto Sapucaí

Tabela 4: População ocupada por setores econômicos (2000) nos municípios da APA da Serra da Mantiqueira e da Bacia Hidrográfica do Alto Sapucaí 114

Tabela 5: Índice de desenvolvimento humano nos municípios da APA da Serra da Mantiqueira (1991/2000) 116

Tabela 6: Crescimento da População Urbana em municípios do Sul de Minas no período de 1970 até 2000 126

Tabela 7: Comparação do rítmo de crescimento da população urbana entre municípios do Sul de Minas. $1970=100$ 126

Tabela 8: Evolução do Índice de Desenvolvimento Humano em municípios do Sul de Minas 


\section{INTRODUÇÃO}

A busca pela sustentabilidade se tornou premente na atualidade para as mais distintas regiões. Esta busca traz necessidades de formulação de estratégias, planos e instrumentos para sua efetivação. Apesar da universalização da idéia de que a preservação ambiental é primordial, não se tem conseguido avanços suficientes na melhoria da qualidade de vida humana e no equilíbrio ambiental planetário. Esta questão é explicada por teóricos de correntes de pensamento diversas, e assim têm sido multiplicadas as pesquisas sobre este tema. Estas discussões e propostas são de extrema importância social, se o que se pretende for um reequilíbrio ambiental na Terra.

Já que a dificuldade maior está na aplicação de propostas teóricas já muito bem formuladas, as discussões sobre o Planejamento Ambiental são imprescindíveis. Entretanto, os instrumentos de Planejamento e Gestão somente podem ter sua finalidade cumprida se houver um real interesse de mudança dos valores, do comportamento de pessoas e da estrutura das instituições sociais existentes. Se não houver este comprometimento, os planos serão fadados ao fracasso, e na história não faltam relatos que comprovem esta idéia. Sendo assim a formulação dos instrumentos de planejamento estão extremamente ligados às bases teóricas que os sustentam.

Neste trabalho serão discutidas as teorias do planejamento ambiental, seus pressupostos e possibilidades através do estudo de uma região rica em recursos naturais, em possibilidades de desenvolvimento humano e cultural: a região do Alto e Médio Sapucaí, no Sul de Minas Gerais. A idéia inicial sobre esta região é que a mesma não tem conseguido aproveitar o potencial de desenvolvimento econômico, 
ambiental, paisagístico e social que apresenta, como também ocorre em outras regiões brasileiras. Aí se estabelece o desafio deste trabalho, desvendar entre técnicas, teorias e práticas os mistérios desta região e chegar à proposição de caminhos possíveis para sua sustentabilidade e harmonia futura.

\section{Hipóteses de Trabalho e Objetivos}

O objeto de estudos deste trabalho é a região da bacia hidrográfica do Sapucaí em sua porção alta e média. Pode ser entendido como um estudo do planejamento ambiental da Bacia Hidrográfica do Sapucaí, levando-se em consideração aspectos relevantes, quais sejam: a existência de áreas de Preservação Ambiental (APA da Serra da Mantiqueira); sua conformação dentro de um eixo econômico (A Rota Tecnológica 459, da Rodovia Juscelino Kubichek) que liga a Rodovia Fernão Dias à Rodovia Presidente Dutra; e sua relação com os circuitos turísticos que podem significar uma alternativa sustentável para seu desenvolvimento (Circuito Turístico Caminhos do Sul de Minas, Terras Altas da Mantiqueira e Rota da Estrada Real).

O objetivo principal deste trabalho é gerar uma reflexão sobre as possibilidades do desenvolvimento com sustentabilidade para a região da Bacia Hidrográfica do Sapucaí, em sua porção alta e média, e a proposição de diretrizes para o Planejamento ambiental, utilizando-se a metodologia de cenários ambientais proposta por Franco (2001).

Os objetivos secundários são:

- Apresentar uma caracterização da região estudada de maneira adequada para as análises ambientais pertinentes; 
- Apresentar uma discussão sobre os conceitos, teorias e métodos do planejamento ambiental;

- Apresentar uma discussão sobre os circuitos turísticos Estrada Real e Circuito Turístico Caminhos do Sul de Minas e Terras Altas da Mantiqueira e suas potencialidades como fatores de desenvolvimento regional.

A hipótese principal deste trabalho é que a região do Alto e Médio Sapucaí não tem se organizado suficientemente para aproveitar o potencial de desenvolvimento econômico, social e ambiental de que dispõe. Desta idéia surgem algumas premissas que podem ser levantadas para responder por que esta região é vista como promessa futura, e historicamente isto ocorre, porém parece pairar no ar o fato de que não é possível se alcançar o desenvolvimento esperado. Neste sentido a primeira premissa que se apresenta é que, na verdade, o potencial para o desenvolvimento é desconhecido ou pouco valorizado pela maioria da população e também pelo poder local. A segunda diz respeito aos entraves colocados pela competitividade entre municípios e regiões brasileiras, que acaba por favorecer grandes empresas e capitais, algumas vezes externos, trazendo desequilíbrios sociais e ambientais, mesmo onde se tem relativo desenvolvimento econômico. Este fato tem levado a um desenvolvimento tecnológico predatório, e isto não é uma particularidade da região estuda. A terceira premissa apóia-se na idéia de que é preciso ser inovador no planejamento e na gestão ambiental desta região para que seu potencial seja realmente aproveitado. E, a quarta premissa é que a cultura, o turismo e o potencial humano, se forem acessíveis e colocados como valores que tragam benefícios para a maior parte da população nesta região, poderão alavancar um desenvolvimento que seja realmente inovador e único. 
Para responder a estas hipóteses a estrutura deste trabalho foi dividida em três partes:

$\mathrm{Na}$ primeira são apresentadas as discussões teóricas e metodológicas referentes à conceituação de ambiente, sustentabilidade, planejamento ambiental e da paisagem.

Na segunda parte são apresentadas as características e potencialidades para a conservação ambiental e paisagística da região da Bacia Hidrográfica do Alto e Médio Sapucaí, tendo como fatores primordiais a discussão sobre as determinações econômicas, sociais e o potencial cultural e turístico.

$\mathrm{Na}$ terceira parte utilizando-se da metodologia de planejamento ambiental proposta, são mostradas as perspectivas de desenvolvimento para a região estudada, formulando-se assim cenários de desenvolvimento futuro constituídos de estruturas sistematizadas, mas não rígidas, como recomendações de ações do planejamento ambiental. 
PARTE I

FUNDAMENTAÇÃO TEÓRICA E METODOLÓGICA 


\section{CAPÍTULO 1}

\section{AMBIENTE E PAISAGEM: ORIGEM E CONCEITOS CONTEMPORÂNEOS}

"Quando a vida destrancou a porta do tempo Derramou semente d'água, do fogo, do vento Minerais, vegetais, bichos e gente Quanto tempo não se sabe ainda Pro tempo o eterno é um segundo Enquanto houver planta florida é tempo de gente no mundo Enquanto houver água tem vida e é tempo de gente no mundo." Joraildes da Cruz (Textos do CD Espelho d'água produzido por Dercio Marques)

Neste capítulo são apresentados alguns conceitos primordiais para a discussão proposta nesta tese, sem os quais não se poderia chegar a uma conclusão final a respeito das perspectivas do planejamento ambiental para a Bacia Hidrográfica do Sapucaí. Sendo assim apresenta-se aqui como são entendidos e contextualizados temas como: Ambiente, Sustentabilidade, Paisagem, Planejamento Ambiental, Planejamento Urbano, Urbanismo, Gestão Ambiental e Turismo.

Não se pretende um esgotamento destes temas uma vez que sua interdisciplinaridade torna esta tarefa impossível. O objetivo ao se apresentar conceitos sobre estas categorias de estudo é explicitar como são entendidas as mesmas neste trabalho. Entretanto, as visões sobre estes temas têm se tornado, na atualidade, tão diversificadas, que, muitas vezes, se apresentam como contraditórias. Sendo assim apresenta-se aqui algumas das possibilidades de 
categorização das visões contemporâneas sobre estes temas e suas origens e como estes são entendidos neste trabalho.

\section{1 - Ambiente}

Citando Cícero, Crowe (1995) argumenta que nós marcamos nossa presença no mundo através de construções, fazendas, cidades, e criamos uma segunda natureza. Todo o conhecimento está fundamentado na observação e nas "Leis" da natureza. A partir desta idéia inicial, os termos ambiente ou meio ambiente podem ser entendidos de duas formas: a primeira trata da transformação da natureza pelo homem e a segunda trata da observação e do conhecimento a respeito das leis e do funcionamento da natureza. Ambas as formas tem sido objeto de estudo da ciência, e, conseqüentemente, o aprofundamento da ciência nestas maneiras de ver o ambiente, tem trazido modificações na realidade e no cotidiano da vida humana no planeta terra. Neste trabalho de pesquisa estas duas formas de entendimento do ambiente perpassam todas as discussões realizadas visto que o conhecimento sobre a realidade natural evolui ao mesmo tempo em que também evolui a forma de interferência humana na natureza. Ambas as formas de entendimento se interconectam na construção do cotidiano dos espaços urbanos e regionais.

Soma-se a esta discussão o fato que nos últimos 30 a 40 anos, as expressões que evocam a discussão sobre os problemas ambientais, têm afetado os debates mais relevantes da sociedade em geral, não ficando restrita mais somente a governos ou pesquisadores, representando uma verdadeira revolução de hábitos e valores (GERTTARDT e ALMEIDA, 2005).

Gerttardt e Almeida (2005) apresentam uma discussão crítica sobre as três maneiras de se ver a questão ambiental na atualidade, a partir da seguinte pergunta: 
o que faz com que a idéia de crise ambiental se universalize, colocando em xeque o aparente otimismo que envolve a ciência, o progresso técnico e mesmo os atuais projetos modernos hegemônicos de sociedade.

A primeira resposta argumentada é que esta universalização da questão ambiental vem da observação de transformações ambientais drásticas, as catástrofes sucessivas que se relacionam ao desenvolvimento técnico-econômico dos últimos 40 anos, que incluem os problemas ambientais globais, tais como: o efeito estufa e as mudanças climáticas, as falhas na camada de ozônio e as perdas incalculáveis de biodiversidade. Seria uma espécie de somatório de resultados negativos do sistema capitalista de produção personificado em estruturas como o mercado, o estado, o desenvolvimento tecnológico e a própria ciência responsável pelo desencadeamento deste processo.

A segunda resposta parte de um ponto de vista evolutivo e de uma abordagem diacrônico-narrativa sobre a consolidação do pensamento ambiental em nível mundial. Procura rastrear na história as origens do ambientalismo ou ainda da crise ecológica atual e como conseqüência as possíveis razões e motivações para o surgimento de uma nova ética ecológica. Há, então, uma tentativa de periodização de todo este processo histórico.

A terceira resposta procura tirar o foco da discussão a respeito dos fenômenos que caracterizam a crise ambiental ou as catástrofes, para centrar este foco em uma espécie de concorrência social pela definição destes mesmos problemas como sendo socialmente relevantes. A problemática ambiental teria que ser compreendida não como algo decorrente, por exemplo, de certas falhas ou contradições inerentes ao padrão de produção contemporâneo, ou, como uma espécie de núcleo aglutinador de um fato social que é ao mesmo tempo, produto de 
um constante processo assimétrico de definições coletivas e de reelaborações de valores da sociedade. Pesada desta forma a problemática ambiental seria vista como uma questão socialmente construída, ou, dito de outra forma, como um problema que existe principalmente em termos de como está definido na sociedade.

Para a discussão sobre o conceito de ambiente neste trabalho adota-se como ponto de partida as seguintes idéias: existe uma definição que parte dos conceitos da ciências físicas e naturais (biologia e física e a ecologia) e existem conceituações que partem das discussões das ciências sociais. Na tentativa de se fazer uma abordagem mais interdisciplinar possível, pretende-se centrar as discussões sobre ambiente tendo como partida estes dois pressupostos. Entretanto ressalta-se que os conceitos aqui apresentados se referem ao que na atualidade pode ser entendido e contextualizado a respeito da questão ambiental, ainda que muitos destes conceitos sejam explicados por raízes históricas.

A seguir são discutidas as maneiras pelas quais podem ser percebida e entendida a idéia de ambiente natural.

\subsection{1 - Conceituação de Meio Ambiente e as evidências das ciências físicas e biológicas}

As comprovações científicas de mudanças no ecossistema terrestre são extremamente abundantes na atualidade, mas tem-se como marco inicial contemporâneo o trabalho de Odum (1988) que consolida a ecologia como ramo fundamental da ciência contemporânea e traz à tona discussões sobre os desequilíbrios ambientais. 
Na física as discussões da física quântica, traçam novas formas de visão da natureza e também colocam em evidência o relacionamento homem-natureza, destacando-se o trabalho do físico Fritjop Capra.

Os grandes encontros internacionais que marcaram a mobilização em torno da questão ambiental também explicitaram esta evolução da visão dos problemas ambientais contemporâneos como um fato sobre o qual não se conhecia o suficiente, e quando isto acontece, este fato já se apresenta como ameaçador, ou seja, a ecologia é melhor conhecida, quando já existe um processo de desequilíbrio em curso.

O início de uma visão centrada nos limites do crescimento ficou explicita no relatório do Clube de Roma de 1971, cujas críticas posteriores trouxeram também discussões a respeito das diferenças sociais e da dificuldade de se criar um modelo de desenvolvimento que servisse a diferentes regiões do planeta. Inicia-se aí uma discussão política que parte de um relatório acusado de simplista para a adoção da complexidade como forma de solução dos problemas ambientais.

As discussões da física e da biologia influenciam muito as discussões das ciências sociais a respeito da questão ambiental e também os movimentos sociais na atualidade, e com freqüência os pressupostos destes ramos da ciência são usados para referendar estas mesmas discussões teórico-práticas. Sendo assim cabe salientar que é necessário, para o escopo deste trabalho, um conhecimento destas teorias das ciências naturais apenas com o objetivo de se entender os pressupostos que irão proporcionar as discussões das ciências humanas, visto que no âmbito das ciências naturais também existem paradigmas e discussões que não têm necessariamente uma visão unificada dos pesquisadores da área. 
Neste sentido o que se coloca como importante para a abordagem proposta neste trabalho é o fato que o conhecimento da realidade biofísica tem, ao longo da história, incentivado movimentos sociais e teorias que de certa forma engendram as práticas do planejamento ambiental e que, na atualidade são entendidas como biocêntricas.

\subsection{2 - Conceituação de Ambiente segundo perspectivas da crítica ao modelo capitalista de desenvolvimento}

Segundo Faria (2002) o modelo atual de desenvolvimento do capitalismo, a globalização, está sustentado por uma grande produção de conhecimentos científicos e tecnológicos que o impulsionam no processo de produção e circulação de mercadorias, mas no centro permanecem a remuneração do grande capital e o lucro das grandes empresas. O fato novo da atual fase do capitalismo não é a centralidade do lucro e do processo de acumulação, mas a escala de ação das empresas e o crescimento de sua importância na determinação sobre os mais diversos locais do mundo.

O retorno do investimento das grandes corporações é o objetivo principal dos agentes hegemônicos para a continuidade da competitividade mundial. Sendo assim suas ações freqüentemente levam a uma desagregação das sociedades, de sua cultura, e também principalmente a uma desorganização de seu espaço.

As riquezas naturais presentes nos diversos territórios são explorados para a produção do lucro. Ao transformar os elementos naturais em recursos, o capital ignora os limites da exploração e gera grandes catástrofes ambientais. 
A fluidez imposta pelo grande capital ao espaço, faz com que os diversos lugares estejam subordinados a uma lógica estranha à suas sociedades e aos seus limites naturais de exploração de riquezas, e esta lógica frequentemente é extremamente veloz se comparada à capacidade de resposta do meio. A velocidade é um elemento central na competitividade mundial: mas o ritmo imposto pelos agentes hegemônicos deve ser visto como violência, pois não pode ser acompanhado pela capacidade de reprodução dos sistemas naturais e sociais. Desse descompasso resulta uma crescente degradação do meio ambiente.

Toda esta transformação, segundo Faria (2002), advém de uma visão de separação homem e natureza que, presente desde o início do século XX, traz a busca de uma idealização da natureza, separando-se a história social e a dinâmica natural.

A natureza parece cada vez mais como forma ideal de equilíbrio, uma espécie de paraíso para o qual os seres humanos representam uma ameaça, pois não fazendo parte de sua dinâmica, suas ações são sempre de construção de desequilíbrios, de decomposição da ordem.

As sociedades também aparecem como conceitos abstratos, o espaço produzido ao longo da historia, sempre sujeito às contradições sociais, mergulhado nas disputas do cotidiano surge como elemento dado.

Há, na realidade, uma idéia de que é possível se criar um paraíso, reequilibrar o ambiente, sem que seja necessário rever os problemas intrínsecos ao capitalismo, as diferenças de classe, o papel do estado, etc. Nesse sentido podem ser detectadas uma série de iniciativas de grandes empresas e da sociedade civil organizada que de certa forma atestam esta visão, tais como as certificações ISO 14000, os selos verdes e outras iniciativas, que, fazendo parte da agenda de grande 
corporações buscam equacionar desequilíbrios ambientais relacionados as mesmas, mas na verdade não deixam de gerar exploração de recursos sociais e ambientais no local onde se instalam. Críticos como Layargues (1992) vêm apresentando estas iniciativas como ações que na verdade são movidas mais por interesses de competitividade do que de real preocupação com as questões ambientais. Os estudos de Porter (1995) também têm apontado uma relação intrínseca entre a busca por competitividade e os investimentos privados em meio ambiente.

Milton Santos (1999) discutindo a crise ambiental afirma que: "a dinâmica dos espaços da globalização supõe uma adaptação permanente das formas e das normas". Sendo assim, as formas de controle ambiental são induzidas da seguinte maneira: as normas globais induzidas por organismos supranacionais e pelo mercado tendem a configurar as demais. E as normas de mercado tendem a configurar as normas públicas. Sendo assim há uma dominação do local pelo global e do público pelo privado, como muitos outros autores também já discutiram. Neste sentido a questão ambiental se torna uma questão emergente, mas sujeita a ideologia capitalista. Como o capital é global, em uma determinada localidade pode haver acréscimo de aporte de capital, entendido como crescimento econômico, mas não acréscimo de capital para os moradores do local, mas sim para um outro ator, externo. Neste sentido pode haver maior vulnerabilidade ambiental quando há crescimento econômico.

$\mathrm{Na}$ abordagem de Marx as relações sociedade/natureza são enfocadas em termos das formas como determinada sociedade se organiza para o acesso e uso dos recursos naturais. As relações entre os homens estão permeadas de contradições, e na medida em que estas são contraditórias as relações com a natureza também o são (BERNARDES e FERREIRA, 2003). 
Desde o século XIX a teoria Marxista tem permitido uma discussão aprofundada de incontáveis pesquisadores que discutem que o sistema capitalista traz desigualdades sociais, espaciais e materiais. Muitos autores da atualidade têm se apoiado nesta linha de pensamento para explicar o desequilíbrio ambiental global, exacerbado pelos efeitos de universalização do sistema, em virtude do fenômeno da globalização.

\subsection{3 - Conceituação de Ambiente em uma perspectiva histórica}

As raízes históricas do que hoje se entende por ambiente podem ser muito remotas. Neste trabalho foram pinçadas apenas aquelas que podem explicar o conceito contemporâneo de ambiente. Não há assim a pretensão de se realizar um estudo histórico, mas apenas a busca de referências históricas que irão influenciar práticas e teorias contemporâneas relacionadas à questão ambiental.

Nos séculos XV e XVI, na Inglaterra, há uma mudança dos sentimentos ou da sensibilidade do homem em relação à natureza. A idéia de dominação da natureza advinda de um sentimento de horror a algumas espécies se sobrepõe à idéia medieval de direitos da natureza, representada pelas plantas e animais, nas concepções religiosas de então. (FARIA, 2002 apud THOMAS, 1998).

Nos séculos XVII e XVIII esta visão é revertida, quando os ingleses de todas as classes sociais se sentem prejudicados pelos efeitos da poluição nas cidades. Há uma retomada da apreciação dos benefícios da natureza e uma valorização do campo e das florestas, por todas as classes sociais. As montanhas e florestas passam a representar locais para buscas espirituais e refúgio, e não mais locais obscuros e temidos. "Thomas avalia que a Inglaterra, pioneira na empreitada de 
promover um absoluto domínio sobre o mundo natural, acaba por perceber que os limites de seu projeto estão no próprio bem estar da espécie humana" (FARIA, 2002 apud THOMAS, 1998). Esta mudança de visão se consolida no século XIX.

Diegues (1998) explanando sobre as bases teóricas que proporcionaram a forma como a sociedade moderna desenha, elabora e gerencia suas áreas protegidas, traça, em perspectiva histórica, a idéia de conservação e de preservação, nascidas nos Estados Unidos, no século XIX, e que posteriormente, irão influenciar correntes de pensamento e práticas relacionadas à questão ambiental.

O Movimento Conservacionista teve como precursor um engenheiro florestal, Gifford Pinchot, treinado na Alemanha e que foi o primeiro Chefe do Serviço de Floresta americano. Baseava a idéia de conservação em três princípios: o uso de recursos naturais para as gerações presentes; a prevenção do desperdício; e o uso dos recursos naturais para benefício da maioria dos cidadãos. É considerado um dos primeiros movimentos teórico-práticos contra o "desenvolvimento a qualquer custo", e é também apontado como precursor da idéia de desenvolvimento sustentável (DIEGUES, 1998).

O preservacionismo foi inspirado na obra de Henry David Thoreau, que em meados do século XIX, trazia a essência da idéia preservacionista, que seria a reverência à natureza, no sentido da apreciação estética e espiritual da vida selvagem. Outro autor importante para a formulação da corrente preservacionista foi Marsh (1801-1882), que foi pioneiro ao analisar os impactos ambientais negativos, nos Estados Unidos, da forma de desenvolvimento social corrente. Entretanto, foi John Muir o teórico mais importante do preservacionismo, que também era ativista 
político. Dentre suas ações destacam-se a criação do Sierra Club, influente organização ambientalista, e também a criação do Parque Nacional de Yosemite.

O preservacionismo foi influenciado também pelo Darwinismo, destacando-se a influência de Ernest Haeckel, darwinista alemão, que apresentou uma definição da ecologia, segundo a qual os seres vivos interagem entre si e com o meio.

Posteriormente a idéia de natureza intocada e a preservação de áreas tendo como causa a beleza cênica e os benefícios intangíveis que poderiam trazer, vai ganhando um enfoque científico com os estudos da ecologia, chegando ao século $\mathrm{XX}$ nas idéias do biocentrismo, tendo como exemplo o trabalho de grande repercussão, da bióloga americana, Rachel Carson, o livro Silent Spring de 1961 (DIEGUES, 1998).

A idéia de natureza intocada ganha assim rumos talvez impensados por Thoreau. No que se refere às áreas protegidas e ao modelo de gerenciamento adotado em sua estruturação nos Estados Unidos, que posteriormente será exportado sem adaptações para outros países, o modelo preservacionista irá receber muitas críticas destacando-se as seguintes:

- o desligamento do homem do meio;

- a não observação de que nem todos as sociedades são dissociadas da natureza, como por exemplo as chamadas populações tradicionais. Diegues (1998) apresenta vários exemplos de criação de parques na África, Austrália, Estados Unidos e países da América Latina, em que, quando houve a expulsão de sociedades locais tradicionais, como indígenas, aborígenes e outras, há um desequilíbrio ambiental, ou seja, o homem, destas sociedades, mantinha o equilíbrio ambiental destas áreas. 
Pode-se assim observar que a idéia preservacionista é precursora do biocentrismo e a idéia conservacionista do Antropocentrismo representado pelo conceito de Desenvolvimento Sustentável.

Outra observação imprescindível é que segundo Faria (2002) o dilema ambiental é construído juntamente com a modernidade, no seguinte sentido: há uma mudança de pensamento em relação à natureza que se consolida no século XIX, trazendo a valorização da idéia e das práticas de preservação ambiental. Entretanto, esta visão é incompatível com o desenvolvimento do sistema capitalista, tornando-se assim um dilema.

Pode-se dizer que nos séculos XX e início deste século, a proeminência do dilema da degradação ambiental é inegável. No mundo globalizado este dilema ganha feições de um impasse para o modelo de desenvolvimento global ou para a cultura global (FARIA, 2002 apud GIDDENS, 1991 e KURZ, 2000).

\subsection{4 - Antropocentrismo e Biocentrismo}

O impasse do século XXI relativo à questão ambiental determina teoricamente duas correntes principais de pensamento: a do ecocentrismo ou biocentrismo e a do antropocentrismo.

A visão antropocêntrica coloca o homem e as questões ambientais no centro das discussões e de certa forma propõe que as discussões sejam feitas em termos de políticas e de mudanças institucionais para se resolver o impasse da questão ambiental dos séculos XX e XXI.

A visão Biocêntrica ou Ecocêntrica coloca no mesmo patamar os direitos de homens e de outras espécies e traz discussões da física e da biologia para as 
teorias sobre o ambiente e as práticas dos movimentos sociais, assim como traz conceitos de influência espiritualista.

Percebe-se assim que há uma universalização atual da importância das discussões e ações relacionadas ao ambiente, mas as teorias e práticas de movimentos ambientalistas e cientistas podem ter orientações até mesmo opostas. São citadas a seguir algumas correntes de pensamento que de certa forma se encaixam nas idéias de Biocentrismo ou de Antropocentrismo:

A. Extremamente conservadores como os Neo-Malthusianos: Colocam como principal causa para o fato de estarmos caminhando para um grande desastre ambiental planetário a superpopulação, principalmente a de baixa renda. (BERNARDES e FERREIRA, 2003). Esta linha de pensamento é antropocêntrica, visto que a preocupação é com a sobrevivência humana, entretanto, difere diametralmente de outras correntes de pensamento também antropocêntricas. As idéias do Clube de Roma podem se encaixar nesta linha de pensamento.

B. Correntes mais progressistas que criticam a estrutura do Capitalismo, tendo como exemplo a dos Eco-anarquistas, que, baseados nas idéias do Russo Kropotkim, propõem que as Sociedades podem viver em harmonia com a natureza na medida em que cultivem a cooperação e não a competição, nem a hierarquia e o poder do Estado. Nesta linha de pensamento as Sociedades mais "Primitivas" são vistas como exemplos (BERNARDES e FERREIRA, 2003). É uma corrente antropocêntrica.

C. Ecologia Profunda: esta corrente mais próxima aos anarquistas questiona o consumismo. Para estes os homens são parte do ambiente, e quanto mais biodiversidade melhor. A hipótese de Gaia, livro de James Lovelock de 1989 representa esta linha de pensamento, onde a terra é vista como um imenso 
organismo e os seres humanos são apenas parte deste organismo individual conectado ao Universo. Segundo Diegues (1998) a Ecologia Profunda apresenta um enfoque essencialmente biocêntrico com influências espiritualistas cristãs ou de religiões orientais e aproxima-se de uma quase adoração do mundo natural.

D. Os Eco-socialistas que articulam as idéias de Karl Marx com os argumentos anarquistas. Para estes o ponto principal para o equilíbrio ambiental do Planeta é a derrubada definitiva do sistema capitalista e a eliminação de todas as formas de injustiça social (BERNARDES e FERREIRA, 2003). Segundo Diegues (1998) apud Robsbawm (1971) a teoria marxista em sua gênese já apresentava a idéia de que a natureza é para este sistema considerada apenas mercadoria, e, como tal é reconhecida não como poder, fato que ocorre nas sociedades primitivas, mas como objeto de consumo ou meio de produção.

\section{2 - Sustentabilidade}

O Discurso dos Movimentos ambientalistas é cheio de contradições, onde são encontradas as mais diversas posturas, desde as mais autoritárias até as mais democráticas. Mas existe um consenso de que o assunto é uma questão de sobrevivência. Graças aos Movimentos Ambientalistas a expressão Desenvolvimento Sustentável ganhou extrema força nos discursos políticos do mundo atual e interpretações variadas.

Para alguns, desenvolvimento sustentável é uma racionalização da sociedade com a implantação de um desenvolvimento mais limpo. Para outros pode ser uma Utopia. Para outros este termo que é muito aceito por todos não está sendo traduzido em ações concretas. 
Desde a conferência de Estocolmo em 1972 foram questionadas as idéias de crescimento Zero e houve reinvidicações dos países em desenvolvimento, liderados pelo Brasil, a este respeito. A partir daí uma série de encontros e mobilizações internacionais buscaram uma resolução da equação do desenvolvimento econômico versos equilíbrio ambiental. Em 1987 o encontro da Comissão Mundial para o Meio Ambiente e o Desenvolvimento (CMMAD) publicou o relatório Nosso Futuro Comum, inaugurando o termo Desenvolvimento Sustentável. A idéia presente neste relatório é que a humanidade deve se organizar para proporcionar desenvolvimento que não afete as futuras gerações. São também levadas em consideração as diferenças de tratamento para os países em desenvolvimento.

A Conferência de Meio Ambiente e Desenvolvimento, conhecida como Eco 92 ou Rio 92, realizada no Rio de Janeiro em 1992, marcou definitivamente a internacionalização da questão ambiental. Criou mecanismos importantes tais como: a Agenda 21; o Fundo Mundial para o Meio Ambiente (Banco Mundial), realizou a Primeira Conferência sobre o Clima que acabou influenciando o encontro de Kioto em 1997.

O encontro promovido pela Organização das Nações Unidas (ONU) denominado Rio +10 , fez um balanço negativo das propostas, instrumentos e ações, firmadas como compromisso de governos e Organizações Não Governamentais (Ongs.) internacionais, na Rio 92.

\subsection{1 - Os impasses da Sustentabilidade}

Quanto às discussões e percalços da idéia de sustentabilidade ressalta-se a seguinte questão: uma vez que a sustentabilidade tem sido consensual por que esta 
é tão dificilmente alcançada? Alguns autores têm formulado suas teorias a este respeito.

Henrique Rattner (1999) apresenta como um dos problemas para a questão do desenvolvimento sustentável a falta de precisão do conceito de sustentabilidade. Outro problema seria a relutância das elites em aceitarem e incorporarem as críticas dirigidas ao modelo de desenvolvimento convencional e ainda dominante, e, sua incapacidade de transformar estas críticas em programas e ações concretas. A fórmula usada nos discursos políticos e científicos, quais sejam as idéias de uma sociedade economicamente viável, socialmente eqüitativa e ecologicamente sustentável, ainda não se tornou presente na realidade, ainda é apenas discurso. Da mesma forma a idéia de equidade entre gerações presentes e futuras e também entre países, não esta sendo praticada.

Os cientistas sociais chamam a atenção para a necessidade de se promover a equidade social, visto que entendem que o desequilíbrio ambiental também é um desequilíbrio social e seus efeitos incidem mais sobre os pobres, os menos favorecidos.

No campo político há o enfraquecimento do Estado-Nação que não se mostra capaz de resolver as carências da população, nem mesmo as mais básicas. Além do mais os movimentos sociais e ambientalistas ainda não dispõem de espaço democrático que garanta que suas reivindicações sejam aceitas e praticadas (RATTNER, 1999).

Para Arlete Moysés Rodrigues (1998) os termos "desenvolvimento" e "sustentável" formam um paradoxo. O termo desenvolvimento esteve ao longo do tempo associado à idéia de "progresso" na concepção da lógica capitalista, que acaba marginalizando questões como a igualdade social e a igualdade entre nações. 
Este termo representa um tipo de progresso baseado na racionalidade do pensamento ocidental que se pretende hegemônica, ou seja, nela não há lugar para outros tipos de progressos, outros tipos de pensamento, sendo que algumas culturas e sociedades minoritárias têm sido praticamente dizimadas, como as indígenas. Já o termo sustentabilidade pretende algo que não é ainda efetivo e portanto necessita de uma outra "visão de mundo" que certamente não é aquela da exploração de recursos e homens, como a da visão capitalista. Assim a união dos termos "desenvolvimento" e "sustentável", para a autora, seria um paradoxo.

O termo "Desenvolvimento Sustentável" carrega em si uma ideologia. Ideologia, no sentido de se atribuir algo do particular ao todo, a generalização perniciosa de algo. Esta generalização passa a ser aceita pelo senso comum, a maioria da população que aceita uma definição sem questioná-la. A ideologia presente na palavra desenvolvimento é que, na prática, algo que é particular, a idéia de progresso, é aceita como pertencente ao todo. A ideologia é que o "Desenvolvimento Sustentável" é divulgado como algo novo, entretanto, na realidade, não existe um novo desenvolvimento, uma vez que o sistema econômico capitalista e seu modo de produção não mudaram. Sendo assim se torna difícil ser apresentado o desenvolvimento sustentável, uma vez que, está baseado em algo que não é real, apenas está baseado na realidade. Da forma como o desenvolvimento tem se direcionado à países pobres e ricos tem sido atribuídas as mesmas tarefas na busca de desenvolvimento sustentável, independentemente de sua capacidade. Como no sistema capitalista existem populações marginais (pobres, minorias), aqueles que não tem capacidade de consumo, estes também estão fora do processo de desenvolvimento sustentável uma vez que a questão da equidade 
social tem sido relegada a um plano secundário, nos discursos e ações políticas (RODRIGUES, 1998).

O Economista Herman E. Daly (2004) afirma que é "impossível sair da pobreza e da degradação ambiental através do crescimento econômico mundial." Sendo assim critica a confusão criada sobre o termo Desenvolvimento Sustentável, relatando que este não tem sido compreendido como deveria. Só seria possível haver desenvolvimento sustentável se o termo desenvolvimento sustentável não fosse confundido com a idéia de crescimento sustentável. Dentro de um sistema com limites para o crescimento como é o sistema ecológico, não se pode pensar em crescimento constante da economia, que pressupõe uso de recursos naturais o que implica em poluição e impactos ambientais. Sendo assim Desenvolvimento Sustentável é possível para economia desde que entendido como desenvolvimento sem crescimento. Isto não significa que a sociedade estacionaria economicamente, mas seu desenvolvimento seria aperfeiçoado em conhecimento, organização, eficiência técnica e sabedoria, realizando isto sem a necessidade de acrescentar uma percentagem cada vez maior de matéria-energia dos ecossistemas.

Segundo Rattner (1999) alguns economistas defendem a racionalização dos processos econômicos, a alocação eficiente de recursos naturais (forma de produção). Mas a idéia de reduzir consumo e equilibrá-lo internacionalmente não tem sido possível, visto que não existem mecanismos ou órgãos internacionais capazes de realizar este controle. Além disso, a forma tradicional de desenvolvimento - crescimento econômico e depois distribuição de renda, tem se mostrado ineficiente. Na maior parte das vezes há crescimento, mas não há distribuição. 


\subsection{2 - Propostas de solução para os impasses da Sustentabilidade}

Rattner (1999) afirma que, em síntese, a busca pela sustentabilidade tem gerado conflitos entre os atores sociais, de um lado a ganância e o interesse próprio individual, de outro, a demanda imperativa por ajuda mútua e cooperação. Neste sentido se o desenvolvimento sustentável ocorrer sem mudanças sociais, como afirma Rodrigues (1998) este não se efetivará, pois estará pautado em uma concepção errônea, ideológica, e superficial, sendo assim, é uma utopia que não tem chance de tornar-se realidade.

O termo sustentável abrange parâmetros que necessitam de mudanças sociais, sendo assim a busca por uma "Sociedade Sustentável" seria mais adequada do que a utilização do termo "Desenvolvimento Sustentável" (RODRIGUES, 1998).

A transformação radical da forma de exploração da sociedade e da natureza é colocada como primordial. Para tanto é importante se partir do entendimento do mundo da maneira mais realista possível. Através dos movimentos sociais tais como, os ambientalistas, os de gênero (feminino, masculino) e outros movimentos reivindicativos são colocadas questões que permitem que a sociedade revolucione os modos de fazer e os modos de relacionar-se. Estes movimentos devem se fazer presentes e terem poder de decisão final (democratização). Em síntese a capacidade de entendimento da questão ambiental (aspecto científico) a capacidade política (aspecto político) e a participação social (democratização) são apresentadas como uma forma de se buscar o que seria uma Sociedade Sustentável, destacando principalmente a capacidade de pensar, inerente ao ser humano (RODRIGUES, 1998).

Para Rattner (1999) primeiramente, é necessário redefinir o significado de riqueza e progresso em face de uma visão de vida e de sociedade mais integrada e 
sistêmica. É necessário também, realmente entender e aceitar o equilíbrio ambiental como importante para nosso bem estar e qualidade de vida. A sobrevivência da vida na terra depende deste entendimento, entretanto, as funções humanas não devem ser reduzidas às biológicas e as de produção e consumo, existem outros valores extremamente importantes, tais como, cooperação, compaixão e solidariedade. A participação ativa nas decisões sobre a sua própria vida e a vida coletiva dá sentido ao empenho humano. Outro requisito é um sistema político e uma estrutura institucional que permita a participação, autonomia e atendimento de interesses de diversos grupos.

Têm surgido alternativas denominadas por Rattner (1999) de "Sol nascente" para as formas de produção existentes, poluentes e degradadoras, denominadas pelo autor de "Sol poente". Estas alternativas seriam: a utilização mais eficaz de recursos, os compromissos empresariais através de selos verdes e de padrões como a série de normas ISO 14000, etc. Outras ações também apontadas pelo autor seriam a mudança de estilo de vida, buscando o consumo consciente e valores que rejeitam a acumulação ilimitada.

Pode-se dizer que os Movimentos Ecológicos têm provocado mudanças: estilo de vida da classe média ocidental tem se alterado; tem aumentado o consumo de mercadorias ecológicas; a economia doméstica de recursos energéticos é uma realidade; há um crescimento de agências governamentais relacionadas ao Meio Ambiente, a poluição tem diminuído em algumas partes e aumentado em outras. Mas tudo isto não tem sido suficiente para a manutenção de uma verdadeira sustentabilidade.

O que pode ser concluído desta discussão é que para que haja sustentabilidade deve haver mudanças sociais que podem ser relacionadas aos 
valores e atitudes individuais e também mudanças institucionais. É necessária uma mudança humana individual, mas também uma mudança nas estruturas sociais, na forma como a sociedade se organiza. Neste trabalho há a consciência desta necessidade, que deve permear as premissas do planejamento ambiental.

\section{3 - Paisagem, Urbanismo e a Idéia de Ambiente}

O conceito de paisagem como o de meio ambiente evoluiu ao longo da história humana. Pode ser apresentada como uma expressão sensível de uma mediância das relações de uma sociedade com seu ambiente natural. (OSEKI E PELLEGRINO, 2004 apud BERQUE A, 1998).

Quanto à origem do termo, a paisagem constitui-se de representações inventadas no século IV na China cujo significado corresponde ao que se entende no Ocidente por paisagem. Entretanto, diferentemente da concepção oriental, em que há harmonia intrínseca entre representação e representado, ou melhor, entre contemplação e contemplado, no Ocidente o entendimento do termo paisagem traz uma divisão entre a teoria (o pensar) e a prática (o fazer) a paisagem (OSEKI E PELLEGRINO, 2004). A evolução do conceito de paisagem ligada ao conceito de natureza na modernidade européia, permite esta diferenciação, visto que há aí uma divisão entre a natureza em dois modos incompatíveis: aquela revelada pelos sentidos (arte) e aquela analisada pela razão (método científico). (OSEKI E PELLEGRINO, 2004 apud BERQUE, 1998).

Em suas raízes epistemológicas latinas a palavra paisagem indicava a idéia de campo de ambiente rural. O termo em inglês landscape utilizado pelos chamados "pintores paisagistas" do século XVIII também remete a idéia de fuga ao campo, de busca do bucólico. No século XIX a criação de parques urbanos, especialmente os 
americanos mudam a idéia sobre paisagem, associando-a ao refúgio nas cidades e também às áreas de preservação (KATHOUNI, 2006). Esta idéia é bem representada por Frederick Law Olmested, o primeiro a se autodenominar arquiteto paisagista e que revolucionou a idéia de paisagem, com projetos como o Central Park de Nova York e o sistema de parques Emerald Necklace para a cidade de Boston.

Ao lado da evolução histórica a paisagem também apresenta interpretações distintas por áreas de conhecimento. Segundo Oseki e Pellegrino (2004) trazendo a interpretação de Béguin em Le paysage (1995) há três interpretações significativas da paisagem: a dos artistas, a dos geógrafos e a dos arquitetos.

Os pintores renascentistas fornecem à noção da paisagem seu primeiro significado. A arte, em relação à paisagem, pode servir como testemunho e também ajuda a explorar elementos que se encontram ainda latentes (OSEKI E PELLEGRINO, 2004).

No interior da ciência da geografia a palavra paisagem compreende desde uma acepção imprecisa e meramente visual até um conceito rigoroso de geossistema, que funciona como uma síntese de um sistema material biofísicoquímico, que pode ser decifrado nas representações espaciais (OSEKI E PELLEGRINO, 2004 apud ROGERIE ett all., 1991).

Também em sua evolução histórica o conceito de paisagem para a geografia passa da visão da região expressa pela paisagem como moldada pela ordem tecnoeconômica no capitalismo, que determina as opções de ocupação do espaço. Este entendimento culmina na idéia atual sobre a paisagem, na qual a globalização dos mercados, a generalização das redes de trocas e a circulação exacerbada de mercadorias, pessoas e capitais pelo território, permitem a perda do valor informativo 
da paisagem, que se torna um resíduo de regiões naturais entre regiões econômicas, no mundo globalizado (OSEKI E PELLEGRINO, 2004).

Para a arquitetura os edifícios em sua conformação no espaço natural definem a paisagem. Na relação entre construções e paisagens podem ser inferidas duas observações: a primeira é uma qualidade intrínseca das construções em caracterizar regiões, climas e tradições, já que são produzidas pelo meio e são enraizadas no local; a segunda seria a presença de uma sensação de atemporalidade, de valor seguro dos edifícios, contrapondo-se à variabilidade do meio natural (OSEKI E PELLEGRINO, 2004).

A evolução histórica do termo e as visões das ciências e artes da paisagem trazem também, mesclada à sua concepção, a evolução da idéia de ambiente, que na atualidade pressupõe uma visão interpretativa da paisagem buscando os elementos ecológicos que a compõem. A seguinte definição de paisagem apresentada por Magnoli sintetiza toda trajetória do entendimento do termo paisagem e sua ligação intrínseca com a idéia de ambiente:

"Entendo o meio ambiente humano como o resultado das interações das sociedades humanas com o suporte: a base física e biológica que as envolve, contribuindo para este suporte, esta base, de diferentes maneiras para sua subsistência biológica e espiritual. Este suporte, base física e biológica, já tem uma história de interações: desde o aparecimento do homem é objeto da ação do homem, alterando essa base. Daí, poderá se sintetizar a concepção de ambiente como interação da sociedade com o suporte físico, quer tenha aparência comumente denominada 'natural' ou construída. A interação se dá no espaço geográfico pelas adaptações, transformações, readaptações e novas transformações das sucessivas formas encontradas, elaboradas e reelaboradas. $A$ essas conFORMAações, conFIGURAções, carregadas da interação social com o suporte temos denominado PAISAGENS. (MAGNOLI, 1986). 
Muitos autores do século XX apresentam o conceito de paisagem da seguinte forma: "A imagem que pode ser obtida por um lance da vista é a paisagem" (KATHOUNI, 2006). Este conceito representa a idéia mais próxima do conceito de paisagem hoje, representando não somente áreas naturais, mas urbanas também.

Para Franco (1997) o significado do termo paisagem se tornou muito abrangente, o que às vezes pode fazer com este sirva para cognições diversas. Pode ser apresentada como ilustração desta idéia a atividade do arquiteto paisagista que representa o profissional que estrutura, projeta e organiza os espaços livres, externos de uma edificação. Quando se muda de escala, a urbana ou a regional a atividade que se associa ao estudo e transformação da paisagem é o que hoje principia-se a ser chamado de Planejamento Ambiental ou Planejamento da Paisagem, que tem ganhado maior importância na atualidade devido a premência de sua aplicação.

\subsection{1 - Paisagem urbana}

A evolução do conceito de cidade é acompanhada de uma evolução do conceito de paisagem. A paisagem no século XX torna-se cada vez mais associada ao urbano (KATHOUNI, 2006 apud SANTOS, 1985).

O processo de urbanização iniciado a mais ou menos 10.000 anos, quando começa a existir uma população urbana, ou seja, quando alguns indivíduos deixam de produzir diretamente seus alimentos, é continuado no tempo. Este processo de urbanização que representa toda história urbana, em um período muito longo de tempo, na atualidade reflete uma paisagem em que, em muitos países, $97 \%$ ou $98 \%$ da população é urbana (REIS FILHO e MEDRANO, 2007). 
A forma urbana, ou a paisagem urbana traz elementos naturais e construídos socialmente e o desafio dos planejadores, dos arquitetos e dos urbanistas é entender estes processos para realizar um trabalho adequado de transformação urbana. Estes profissionais trabalham com dois universos fundamentais: o universo empírico, que são dados que são levantados na observação da realidade; e o universo teórico que são a organização destes dados de forma racional. Sendo assim ao lidar com estes dois universos estão presentes valores que determinam a forma como a realidade é vista (REIS FILHO e MEDRANO, 2007).

Além da natureza e das relações sociais na paisagem urbana, outro elemento importante é a maneira pela qual se entende ou se enxerga esta paisagem. Esta maneira está impregnada de valores culturais, do momento histórico, da realidade social e geográfica do observador. Os geógrafos se destacaram no estudo desta idéia que seria a da percepção ambiental tendo como culminância o trabalho de YiFu Tuan sobre a Topofilia, topofobia e lugares valorizados.

Segundo Goitia (1991) a cidade pode ser estudada sob um número infinito de ângulos:

- O da História: "a história universal é a história das cidades". (Spengler)

- O da Geografia: "a natureza prepara o local e o homem organiza-o de maneira a satisfazer seus desejos". (Vidal de La Blanche)

- O da Economia: "em nenhuma civilização a vida das cidades se desenvolveu independentemente do comércio e da indústria". (Pirenne)

- O da Política: a cidade, segundo Aristóteles é um certo número de cidadãos.

- O da Sociologia: "a cidade é a forma e o símbolo de uma relação social integrada". (Munford) 
- O da Arte e da Arquitetura: "a grandeza da arquitetura esta ligada à da cidade, e a solidez das instituições costuma avaliar-se pelos muros que as protegem". (Alberti)

- A do Meio Ambiente: a cidade alberga a vida, a ponto de nos confundir e nos fazer crer que são as cidades que vivem e respiram.

- A da Literatura (dos poetas e escritores): "tudo o que afeta o homem está presente na cidade, e na maioria das vezes os poetas e escritores é que a descrevem melhor".

- E outras tantas.

Por mais esforço que fizermos no estudo da cidade, teremos ainda um conhecimento fragmentado. Então enfrentaremos dificuldades: a primeira dificuldade é sua definição: Existem inúmeras definições, por vezes muito diferentes entre si. Por serem diferentes não se pode escolher uma certa e uma errada, apenas representam conceitos muitas vezes opostos ou se tratam de cidades que são constitutivamente diferentes. A Polis grega não tem nada a ver com uma cidade medieval; uma vila cristã e uma medina mulçumana, são distintas uma da outra, da mesma forma que uma cidade-templo, como Pequim e uma metrópole comercial como Nova York (Goitia, 1991).

$\mathrm{Na}$ atualidade a paisagem está muito associada à idéia de urbano, e o termo paisagem não designa mais somente a idéia de campo e rural, mas, de cidade, em virtude de todo processo de urbanização ocorrido em um longo período histórico. Se a maioria da população é urbana a percepção do ambiente e da paisagem também é uma percepção urbana. Ou seja, a paisagem urbana, na atualidade não representa só uma dominância de área geográfica, mas também uma dominância de visão urbana. Somos, em grande maioria, seres humanos educados e criados na cidade e 
temos uma visão da paisagem - urbana, rural ou ambiental - que é uma visão urbana.

Da mesma maneira a idéia de paisagem tem como determinante o contexto histórico, social, geográfico e ambiental, fica claro então que ao longo do tempo o conceito de paisagem e de ambiente se altera, ampliando-se e reciclando-se conforme o desenvolvimento da compreensão dos processos formadores e consolidadores da construção dos territórios e paisagens, naturais ou artificiais.

\section{4 - Turismo e Cultura como Fator Indutor de Sustentabilidade}

O Turismo é uma prática social que tem por finalidade proporcionar lazer, entretenimento e descanso à população. Segundo Fonseca (2001) as pessoas de diversas partes do mundo estão cansadas da homogeneidade excessiva de costumes, hábitos e "pseudoculturas", procurando valorizar cada diferença. O turismo vai ao encontro das necessidades atuais, pois: responde à crescente valorização social e política da diversidade cultural; acentua a história (passado e memória, reinventando tradições e lugares); faz do espaço onde se localiza um lugar diferente de todos os outros; converte o patrimônio histórico, cultural, paisagístico e ambiental em um recurso econômico, criador de emprego e gerador de riqueza.

Entretanto, o turismo denominado ecológico ou sustentável figura na atualidade mais como "Slogam" do que como prática, visto que para se ter turismo sustentável é necessário se ter sociedades sustentáveis e as experiências nesse sentido existem, mas são ainda muito pouco expressivas. Segundo Prado (2003) as experiências mostradas em estudos de caso apontam para incongruências na aplicação de idéias gerais do que seria o Turismo Sustentável. Essas idéias gerais 
propostas como metodologias acabam encontrando dificuldades na prática, visto que o desenvolvimento de uma política de turismo sustentável é mais complexa do que as políticas e planos que vem sendo desenvolvidos.

Diegues (1999) em O Mito Moderno da Natureza Intocada defende uma preservação ambiental, especialmente em Unidades de Conservação, que inclua as Populações Tradicionais no planejamento e na Gestão Ambiental, e esta prática vem se mostrando muito satisfatória nas Reservas Extrativistas Brasileiras. A este respeito o trabalho de Prado (2003), em que é apresentado um estudo a respeito do Turismo na Ilha Grande, no Rio de Janeiro, apresenta uma discussão mais focalizada abordando as dificuldades de se concatenar as visões de turistas e nativos ou População Tradicional, para que o turismo seja efetivamente sustentável.

Reforçando esta idéia Alfonso (2003) afirma que o turismo deve ser estruturado de maneira a satisfazer a população local e também o turista.

Percebe-se que o desenvolvimento de uma política para o turismo sustentável deve prever os seguintes aspectos:

- Há uma perspectiva de crescimento econômico crescente para o turismo na atualidade que traz a possibilidade de geração de renda e desenvolvimento econômico se bem administrado;

- Ao mesmo tempo em que o aspecto cultural, especialmente a presença de populações tradicionais e o apelo étnico, são um bem imaterial que pode gerar renda para uma determinada região, a atividade turística não escapa da lógica capitalista e, portanto, é necessário se prever quais os grupos irão se beneficiar economicamente desta atividade;

- O Turismo pode se configurar como uma atividade econômica rentável para uma região e de impacto mais baixo que outras atividades, mas não se pode 
esquecer da estruturação necessária para que não ocorra um descontrole dos fluxos gerando ocupação e especulação imobiliária, fluxos concentrados em determinadas épocas, e outros impactos que acabam se refletindo no ambiente;

- A região aonde o turismo ecológico irá se desenvolver deve ter os aspectos de preservação do patrimônio natural ressaltados.

Sendo assim é necessário frisar que o desenvolvimento do turismo como uma atividade que gere sustentabilidade deve se ater ao cuidado com a inclusão social, a manutenção cultural, a preservação ambiental e a participação das comunidades envolvidas, para que possa realmente render frutos. Henrique A. Prudente (2005) faz uma análise das denominadas culturas subalternas no processo de desenvolvimento do turismo na cidade paulista de Cunha, salientando que é necessário fazer frente à ordem hegemônica existente, que está fundamentada no modo de produção capitalista em nível internacional, evidenciada pelo processo de Globalização. Esta ordem hegemônica pode se tornar degradadora do ambiente e das tradições culturais que são, na verdade, o sustentáculo de um projeto de desenvolvimento turístico. Sendo assim é importante salientar que a construção de um lugar agradável ao cidadão é que traz também a oferta de um lugar agradável ao visitante.

\section{5 - Ambiente, Paisagem e Sustentabilidade na Bacia Hidrográfica do Sapucaí}

Os conceitos apresentados neste capítulo levam ao um entendimento de como é abordada a questão ambiental neste trabalho. Entretanto, é importante salientar aqueles que serão adotados como premissas para o estudo do 
planejamento ambiental na Bacia Hidrográfica do Sapucaí. Sendo assim ressaltamse alguns pontos importantes do entendimento da questão ambiental para os objetivos a serem cumpridos neste trabalho.

A questão ambiental na atualidade é uma questão global, um paradigma que é objeto de discussões científicas e sociais em todo o planeta. A complexidade é um fator constante em todos os projetos científicos e também nas práticas relacionadas à temática ambiental.

Como inferem Oseki e Pellegrino (2004) o planejamento da paisagem ou o planejamento ambiental implica em uma contradição insuperável desde os Gregos, entre o sujeito total - a sociedade, e o objeto total - a natureza. O dilema vivido pela sociedade na atualidade, entretanto, apresenta premência na busca da melhoria da qualidade de vida especialmente urbana, que não pode estar dissociada da qualidade ambiental que representa a base material para o desenvolvimento humano. Sendo assim, mesmo que a complexidade e a contradição sejam inegáveis a necessidade de se desenvolver teorias e aplicações para solução deste dilema que se apresenta como crise ambiental, não pode ser abandonada, sob pena de conseqüências extremamente negativas para as comunidades. Estas conseqüências não são apenas previstas, mas vivenciadas no momento presente por grande parte das comunidades, especialmente as dos países subdesenvolvidos.

Em meio à complexidades e contradições os planejadores ambientais têm a tarefa de estabelecer métodos e técnicas que representem melhorias para a situação corrente, o que implica em fazer escolhas, estabelecer posicionamentos, mas também saber dialogar e principalmente entender seu objeto como uma realidade em evolução, em que seu trabalho é um processo, que pode e deve ser flexível e democrático, mas ao mesmo tempo claro e preciso. 
Diante destas premissas, neste trabalho, ambiente é entendido como uma realidade complexa, um objeto que ainda não é conhecido em todos os seus processos. A ação do homem sobre o meio imprime sua marca na paisagem, signo de todas as ações sociais. Cabe então aos planejadores imprimirem sua marca ainda que não consigam abarcar toda a gama de variáveis e formulas necessárias à solução desta equação. Ainda que tragam valores e posicionamentos pessoais ou determinados por sua formação, por sua realidade social.

Entende-se que o sistema capitalista tem provocado às diferenças sociais, geográficas e ambientais vividas e que a mudança de um sistema é algo que leva tempo e que requer escolhas. $E$ as escolhas sempre envolvem perdas individuais ou coletivas.

É compreendido também que ainda que não seja possível vislumbrar uma mudança do sistema e que a complexidade e as contradições persistam, não se pode deixar de dar o primeiro passo na busca da sustentabilidade, como inúmeras cidades e regiões têm mostrado ser possível. Dessa maneira entende-se que à revelia do sistema e da realidade existe um processo inexorável que consiste no poder de transformação humana que será refletido na paisagem futura, o que nos faz lembrar que planejar pode dar certo, pode ser melhor do que não planejar. 
FUNDAMENTAÇÃO METODOLÓGICA 


\title{
CAPÍTULO 2
}

\section{PLANEJAMENTO AMBIENTAL: CONCEITOS E MÉTODOS}

\begin{abstract}
"Saudação ao Céu e a Terra. Céus e Terra se juntam formando o homem, a natureza e todas as coisas.

O Homem sai em busca do conhecimento.

E o conhecimento o leva até ao Céu.
\end{abstract}

Ele trás para si tudo o que aprendeu e devolve ao mundo, em forma de sabedoria, e o mundo em troca lhe dá mais sabedoria.

Então, abre seu coração ao mundo; e todos os pássaros vêm cantar em seu jardim.

Ele vai em busca de mais sabedoria, as vezes procura ao céu e as vezes a Terra, mas muitas vezes não é compreendido e será agredido.

O homem então se defende, e abre os seus caminhos, mas suas forças não são suficientes, e então, ele pede ajuda ao Céu, e mais forças vêem.

E como um tigre, como uma cegonha, ele remove seus obstáculos e prossegue..." (Trecho do Poema Wu San Dji Tao, ou o Caminho do Venerável Guerreiro, um Kati pertencente à tradição do Tai-Chi-Chuan)

\section{1 - Cidade e Planejamento Ambiental}

Na obra "O Jardim de Granito" Anne Spirn (1995) evidencia a questão ecológica como determinante da qualidade de vida urbana e mostra os impactos ambientais muitas vezes irreversíveis, ocasionados pela inexistência ou fracasso do planejamento e gestão ambiental na história urbana. Nesta obra é apontada a extrema necessidade de se visualizar a cidade como subjacente às condições ambientais.

A consolidação do fenômeno da urbanização de maneira generalizada no Brasil a partir do terceiro terço do século XX, como define Milton Santos (1994), faz 
com que a cidade seja um elemento fundamental para o equilíbrio ambiental. Esta importância também é verificada pelas discussões em nível internacional sendo objeto de debates nas grandes conferências internacionais.

Os ecólogos salientam a importância de se estudar a cidade como um espaço fundamental na perspectiva da busca de um equilíbrio ambiental, como destaca Franco (2001, p. 65):

\begin{abstract}
"Embora as cidades não ocupem uma área muito grande da superfície terrestre (apenas de 1 a $5 \%$ do mundo inteiro, segundo Odum), elas, porém, alteram a natureza dos rios, campos naturais e cultivados, florestas, além da atmosfera e dos oceanos, por causa dos ambientes extensos de entrada e de saída que elas demandam. Um hectare de área urbana consome mil vezes mais energia que área semelhante em ambiente rural."
\end{abstract}

Para Franco (1997) os termos Zoneamento, Planejamento, Projeto e Desenho, acrescido da palavra ambiental são neologismos que representam a transformação que o termo Paisagem pode representar, na atualidade, em razão de toda a mudança de visão e de ações referentes ao ambiente.

Apresenta-se aqui uma amostra das visões de alguns pesquisadores que tem se proposto a discutir e apresentar conceitos e métodos para adequar o planejamento e o desenho urbano às demandas pelo equilíbrio ambiental em distintas ocasiões.

Vitrúvio, autor de Os 10 livros da Arquitetura, mencionava as habilidades e conhecimentos que um bom arquiteto deveria desenvolver no então império Romano. Nestas habilidades incluía o conhecimento sobre a água e o solo ressaltando a importância do suporte físico para o desenvolvimento arquitetônico e urbano (POLIÃO, 2002). Esta observação ilustra que a preocupação com as questões ambientais na vida urbana pode ser vista sob uma perspectiva histórica e reflete claramente a estrutura social e cultural de uma região. 
A obra Projectar con la naturaleza (Design with nature) de lan L. Mcharg (1969), lançada no final da década de 1960, se converteu, na atualidade em um texto clássico e de referência para uma ampla gama de áreas de conhecimento. Em 1992 foi lançada uma edição comemorativa em que o autor revela que com esta obra era possível dar respostas a toda uma série de deficiências óbvias do planejamento. A primeira delas era a ausência de qualquer noção de meio ambiente no planejamento, que naquele momento era um processo exclusivamente sócioeconômico. A segunda era a falta de integração entre as diversas ciências ambientais: os geólogos, os meteorólogos, os hidrólogos e os edafólogos conheciam muito bem as ciências físicas, mas não as da vida; de outro lado, os ecólogos e os biólogos conheciam modestamente os processos físicos. Além disso, os cientistas em geral não mostravam interesse algum pelos valores ou pelo planejamento; finalmente, não existia uma aproximação teórica que abordava o problema das adaptações humanas. Mac Harg propõe a interdisciplinaridade e compõe uma obra muito detalhada sobre os conceitos e métodos que considera mais adequado ao planejamento ambiental.

A discussão realizada por Spirn (1995) no livro O jardim de granito apresenta os desequilíbrios ambientais da realidade urbana na atualidade e formula diretrizes para a solução dos mesmos. A autora aborda diversos aspectos urbanos compartimentados em seis partes: Cidade e Natureza; Ar; Terra; Água; Vida e O Ecossistema Urbano, utilizando-se de uma série de exemplos atuais e históricos da vida urbana americana e européia. Considera que a deterioração social e ecológica de vários aspectos urbanos e a crise de recursos como água, alimentos e energia, leva a um exercício de se repensar a forma como as cidades são planejadas. Afirma que a desconsideração dos processos naturais na cidade é, sempre foi e sempre 
será, tão custosa quanto perigosa. Conclui que muitas cidades sofreram com o erro de não levar em conta a natureza e cita exemplos como os das seguintes cidades: Los Angeles e Nova York com problemas de poluição atmosférica; Cidade do México que afunda por não observar a ligação entre água e solo.

Poucas cidades se adaptaram engenhosamente à natureza tais como: Stuttgart na Alemanha que empregou seus espaços livres na canalização do ar fresco e limpo para o centro congestionado; Filadélfia que utiliza seus resíduos sólidos para gerar uma infinidade de produtos e Zurick e Frankfurt que possuem florestas urbanas para a exploração de madeira e para recreação. As recompensas por se projetar a cidade de acordo com a natureza aplicam-se igualmente a todas as cidades, novas ou antigas, grandes ou pequenas. As soluções não precisam ser abrangentes, mas o entendimento do problema sim. No ambiente natural de cada cidade existem elementos diferenciados e elementos comuns. Muitas cidades devem sua localização, seu crescimento histórico e a distribuição da população, bem como o caráter de seus edifícios, ruas e parques às características diferenciadas de seu ambiente natural (SPIRN, 1995).

As decisões tomadas na cidade ficam a cargo de uma série de especialistas que raramente se comunicam representando uma visão fragmentada para a solução dos mais variados problemas urbanos. A visão fragmentada da cidade se traduz também na forma como são tratadas e administradas suas diversas áreas (centro, periferia). É necessário que a cidade seja vista como um sistema interligado e interdependente. Cada edifício, rua, parque ou espaço da cidade deve ser projetado como parte de um ecossistema e como um mini-ecossitema (SPIRN, 1995).

Para Michael Hough (1998) em Naturaleza Y Ciudad o desenho urbano das cidades tem contribuído pouco para o equilíbrio ambiental e para a qualidade de vida 
humana. A proposta do autor é encontrar novas e construtivas maneiras de enfocar este tema. Nesse sentido destacam-se dois propósitos: oferecer uma base filosófica e conceitual que sirva de apoio ao desenho e planejamento urbano e ilustrar com exemplos reais a aplicação prática de conceitos teóricos. Desta obra podem ser destacadas algumas considerações expressas pelo autor:

1. É evidente na contemporaneidade a separação homem-natureza.

2. A forma como tem sido conduzido o planejamento das cidades contribui para a alteração do suporte físico urbano trazendo desequilíbrios ambientais e enfatizando muito mais aspectos econômicos que ecológicos e sociais.

3. Os valores estéticos que determinam a paisagem urbana na maioria dos casos não incluem características relacionadas à dinâmica dos processos naturais. Existe um conflito de valores no processo de planejamento e desenho das cidades e devem ser adotados novos comportamentos para que estes conflitos sejam equacionados.

4. Uma revisão e modificação dos valores e percepções sobre o meio-ambiente urbano podem construir paisagens mais econômicas e de maior valor social que as tradicionais.

No capítulo I Hough (1998) descreve a evolução da paisagem urbana da industrialização à contemporaneidade examinando as necessidades energéticas para o equilíbrio ambiental e social. Realiza também uma revisão das atitudes e dos valores que geram os problemas ambientais. Sugere alguns princípios básicos de ecologia e métodos de desenho que podem se converter em referência para a questão ambiental urbana. Os capítulos II, III, IV e V tratam da água, das plantas, da vida selvagem e dos cultivos urbanos, referenciando-se sua importância como fatores ambientais afetados e transformados pelos processos urbanos e 
enfatizando-se princípios que devem ser adotados no tratamento destes fatores. $\mathrm{O}$ capítulo VI do livro trata do clima numa visão integrada entre ecologia e planejamento urbano.

Franco (2001) no livro "Planejamento Ambiental para a cidade sustentável" desenvolve uma seqüência de idéias na tentativa de criar um corpus teórico para esta atividade. Em perspectiva histórica afirma que o Planejamento ambiental passa da utopia à necessidade e faz considerações e reflexões profundas a respeito do desenvolvimento sustentável e da evolução da idéia de conservação ambiental no Brasil e no mundo. Também realiza a proposição de uma metodologia própria para o Planejamento Ambiental sugerindo uma abordagem denominada de "Cenários Ambientais".

Podem-se destacar a partir da descrição "pincelada" da obra dos autores acima colocados alguns pontos em comum, quais sejam:

A. A constatação de impactos ambientais advindos de práticas de planejamento e gerenciamento ambiental urbano inadequados;

B. A necessidade de modificações das concepções tecnológicas e culturais no tratamento das questões relativas ao planejamento ambiental;

C. A necessidade de uma visão interdisciplinar que envolva tanto aspectos físicos, biológicos e socio-econômicos para instrumentalizar a ação de planejadores urbanos;

D. A necessidade de mudança das técnicas e procedimentos do planejamento urbano.

Pode-se também destacar alguns pontos fortes desenvolvidos pelos mesmos autores, tais como: 
A. A constatação de que os planos urbanos em sua maior parte tendem historicamente a valorizar aspectos sócio-econômicos é expressa por Mc Harg (1992), Hough (1998) e Spirn (1995);

B. Ann Spirn (1995) destaca a necessidade de aperfeiçoamento técnico ressaltando a formulação de um banco de dados que possa ser concebido de forma que todos os profissionais envolvidos no processo de planejamento possam acessar e utilizar;

C. Hough (1998) enfatiza a possibilidade de aproveitamento do conhecimento presente em cidades "multi-culturais" de populações tradicionais, cujas concepções trazem legados extremamente importantes e que podem ser perfeitamente utilizados na prática do planejamento contribuindo positivamente;

D. Mcharg (1969) considera a importância do desenvolvimento concomitante da interdisciplinaridade e dos conhecimentos particulares a cada ciência como otimizador de uma metodologia que faça do Planejamento Ambiental um instrumento eficaz;

E. Franco (2001) ressalta que é necessário que haja um posicionamento político democrático para que as práticas de planejamento ambiental sejam viabilizadas. 


\section{2 - Planejamento e Gestão Ambiental}

No primeiro capítulo deste trabalho as discussões sobre o entendimento da questão ambiental culminaram na idéia de que o planejamento ambiental é um desafio que coloca, segundo Oseki e Pellegrino (2004) uma contradição insuperável desde os gregos entre o objeto total: a natureza ou a paisagem e o sujeito total - a sociedade. Mesmo diante de contradições como estas, e a imensa complexidade da questão ambiental a tarefa definida pelo planejamento ambiental é esta, e deve ser entendida como uma construção social, um processo que pode ser melhorado, se o desafio for aceito.

A respeito das proposições teóricas que pretendem instrumentalizar os planejadores e gestores urbanos para uma atuação que garanta o resgate do equilíbrio ambiental urbano pode-se salientar que estas se fazem presentes em variadas áreas do conhecimento. A complexidade do tema não permite que exista um consenso em torno de sua forma de aplicação. A cidade, a região e a bacia hidrográfica enquanto objetos de estudo têm sido exploradas a partir dos mais diversos pontos de vista: do Planejamento Urbano e Regional, da Administração Pública, do Desenvolvimento Econômico, e também sob o ponto de vista Ecológico. Nesta última abordagem verifica-se uma real necessidade de avanço, em virtude da constatação de elementos antes não levados em consideração ou relegados a um segundo plano pelas outras formas de se avaliar a cidade enquanto espaço de expressão e desenvolvimento humano.

Por se tratar de uma atividade recente a atividade de Planejamento Ambiental não dispõe ainda de uma definição precisa. O ambiente é interpretado tanto no que se refere às questões humanas quanto físicas e bióticas. São diversas as 
abordagens e definições que o Planejamento Ambiental recebe entrelaçando conceitos que se mesclam. Pode ser confundido com o próprio planejamento territorial e ora é uma extensão de outros planejamentos setoriais mais conhecidos acrescido da questão ambiental, tais como: o urbano, institucional ou administrativo; físico, geoecológico ou estético e paisagístico (Santos, 2004 apud Almeida, 1991).

Há também uma mescla dos conceitos de planejamento e gestão ambiental, fato decorrente da evolução das técnicas de administração ao longo da história, que, ao incluir experiências passadas em planejamento público e privado, adaptaram novos conceitos e técnicas às práticas de planejamento e gestão. Atualmente estas duas atividades são vistas como interdependentes, deixando para trás a herança dos planos de origem militar, de grande escala, onde as ações eram propostas e cumpridas em um espaço de tempo longo, e não havia realimentação deste processo. Com as inovações advindas do modelo gerencial japonês estes conceitos vão mudando e hoje a idéia de planejamento como processo é mais aceita, com a difusão do ciclo denominado PDCA (Plan, Do, Check, Act).

Com estas considerações pode-se dizer então que o planejamento e a gestão são atividades integradas em um processo de planejamento que é visto como sistêmico, e que, portanto pode ser constantemente realimentado com novas variáveis, dados e até mesmo a mudança de objetivos.

Santos (2004) define os termos gerenciamento, gestão e planejamento ambiental da seguinte maneira: gerenciamento ambiental é um momento interativo, uma proposta de ordenamento, na qual o planejamento ambiental predomina nas primeiras fases do processo. O gerenciamento figura nas fases posteriores do ordenamento, ligadas à aplicação, monitoramento, controle e administração das alternativas propostas pelo planejamento. Gestão ambiental deve ser entendida 
como a integração entre o planejamento, o gerenciamento e a política ambiental. A figura abaixo ilustra esta idéia:

\section{GESTÃO AMBIENTAL}
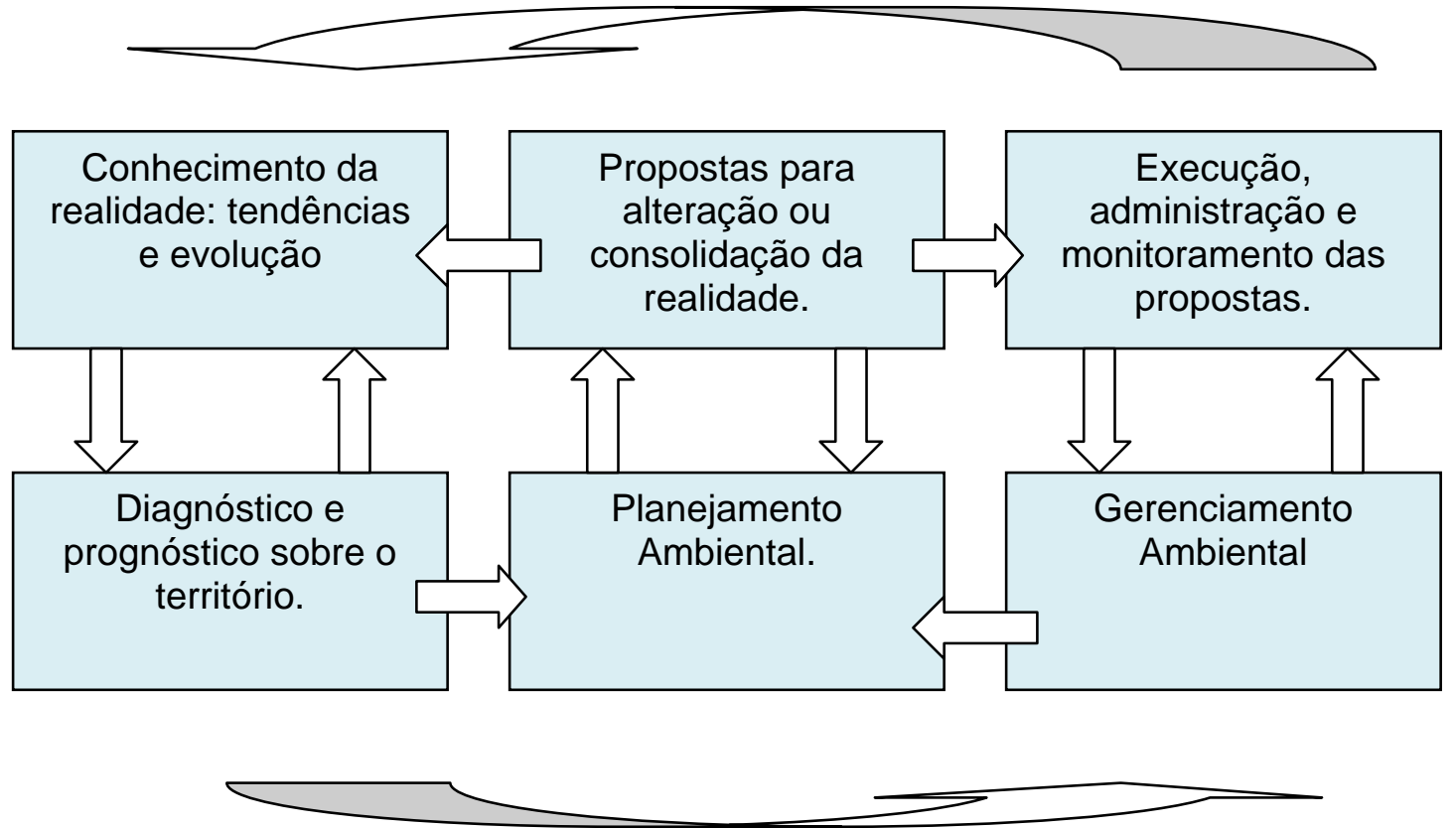

Figura 1: Interações entre planejamento e gerenciamento ambiental Fonte: adaptado de Santos (2004) pagina 27.

O planejamento ambiental pode ser visto como um processo que visa à adequação do uso, do controle e da proteção ao ambiente, além das aspirações governamentais expressas ou não em políticas ou legislações ambientais.

\section{3 - A Bacia Hidrográfica, a Cidade e as Unidades de}

\section{Conservação: Espaço e Tempo no Planejamento Ambiental}

Definir limites para os dados e estudos do planejamento ambiental é um desafio a ser enfrentado, pois diante da complexidade e em função da 
operacionalidade da atividade de planejamento devem ser feitos recortes no espaço e no tempo. O entendimento destes limites e recortes é assim compreendido:

\section{Tempo}

Com relação ao tempo o planejamento ambiental possui escalas diferentes de tempo com que deve trabalhar. Há, porém, ainda uma concepção dual relacionada a este elemento: o tempo histórico (evolutivo e progressivo) e o tempo da terra (cíclico e repetitivo). O desafio do planejamento consiste em se promover uma unicidade de tempo onde este possa ser concebido num fluxo contínuo e integrado (SANTOS, 2004).

As mudanças do meio antropizado e natural devem ser adequadamente contempladas no planejamento ambiental. Esta necessidade leva a se reforçar a importância do trabalho de integração das equipes multidisciplinares no planejamento ambiental, buscando indicadores que satisfaçam tempos de escalas tão diferentes quanto à geológica, de milhares de anos, e a humana, de dezenas de anos. Cabe ao planejador identificar as forças que governam o trajeto das mudanças na paisagem e interferir nos caminhos críticos que afetam a qualidade ambiental (SANTOS, 2004).

Usualmente, o tempo é representado por meio de cenários, que nada mais são do que interpretações de momentos em uma paisagem dentro de uma escala temporal visando auxiliar no entendimento da área estudada.

Área

O desafio do planejamento ambiental se intensifica ainda segundo a escala escolhida no planejamento: a bacia hidrográfica, a cidade ou a região são os objetos do planejamento ambiental em maior escala. Como definir uma boa escala para o planejamento é uma tarefa que o planejador deve enfrentar. 
Em virtude da legislação ambiental brasileira que define a bacia hidrográfica como uma área mais adequada à análise ambiental, especialmente para as Avaliações de Impactos e em virtude de confecção de EIA-RIMA (Estudo de Impacto Ambiental) e seu respectivo (Relatório de Impacto sobre o Meio Ambiente), esta área tem sido adotada como uma boa divisão de escala para o planejamento. Além disso, com a instituição do Sistema Nacional de Recursos Hídricos e da Política Nacional de Recursos Hídricos pela Lei 9.433 de 8 de janeiro de 1997, que coloca a água como um elemento prioritário e merecedor de um sistema de gerenciamento e planejamento próprio dentro das políticas ambientais, a adoção da bacia hidrográfica como objeto de planejamento passa a ser incentivada. Esta legislação dispõe de fundamentos essenciais que influenciam no planejamento ambiental, dentre os quais são destacados:

- A água é um bem de domínio público.

- A água é um recurso natural limitado, dotado de valor econômico.

- O uso prioritário da água em caso de escassez é o consumo humano e a dessedentação de animais.

- A gestão dos recursos hídricos deve sempre proporcionar o uso múltiplo da água.

- A unidade Territorial para implementação da política Nacional de Recursos Hídricos é a Bacia Hidrográfica.

- A gestão de Recursos Hídricos deve ser descentralizada e contar com a participação do Poder Público, dos usuários, e das comunidades.

A democratização do processo de planejamento e gerenciamento das águas presente no Sistema Nacional de Recursos Hídricos e na Política Nacional de Recursos Hídricos faz com que haja uma mobilização em torno da escolha desta 
escala para o Planejamento Ambiental. Entretanto, em virtude de ainda ser recente esta estruturação, há desafios a cumprir, e um deles é a organização e atuação dos comitês de Bacia que necessitam de envolvimento de setores da sociedade para a conclusão de suas políticas.

Segundo Santos (2004) são favoráveis à escolha da Bacia Hidrográfica como área de estudo do planejamento ambiental os seguintes fatores: - a Bacia Hidrográfica constitui um sistema natural bem definido; é de fácil reconhecimento e caracterização; não há qualquer área de terra, por menor que seja, que não se integre a uma bacia hidrográfica; a legislação estabelece como área de estudos de impactos ambientais a bacia hidrográfica; esta escolha também é apoiada pelos ecólogos. E ainda apresenta como fatores não favoráveis a escolha da hidrográfica como limite de estudo do planejamento ambiental os seguintes: a complexidade do estudo de elementos e indicadores se torna muito grande quando a bacia hidrográfica apresenta áreas muito urbanizadas e influenciadas por atividades agrícolas; mesmo sendo uma área extensa pode não contemplar os objetos que se pretende estudar; fluxos econômicos podem extrapolar os limites da bacia hidrográfica; Dados sócio-econômicos, censitários e de infra-estrutura brasileiros são disponibilizados por municípios o que dificulta o acesso e a análise de dados da bacia hidrográfica.

Mesmo com alguns fatores desfavoráveis a bacia hidrográfica em função de representar um ecossistema é uma boa escolha como área de estudo e projetos do planejamento ambiental.

O espaço de trabalho a ser definido no Planejamento ambiental deve flexibilizar seus limites de forma a considerar inter-relações nos seus diversos níveis 
(SANTOS, 2004). Assim a escala temporal e espacial deve ser definida de acordo com os objetivos do planejamento.

\section{4 - Métodos em Planejamento Ambiental}

O planejamento entendido como um procedimento lógico capaz de auxiliar efetivamente os esforços de desenvolvimento econômico e social, teve sua utilização ampliada ao longo da história e após a segunda guerra mundial foi visto como possibilidade de se obter o milagre desenvolvimentista. Pouco tempo depois disto a utilização de planos passa a ser vista como um mito, como algo mágico para se conseguir o que se almeja. Entretanto a prática do planejamento tem mostrado que este instrumento ou este procedimento lógico algumas vezes pode não funcionar. Sendo assim foi necessário um estudo mais aprofundado do que poderia ser considerado um bom planejamento. Foi entendido através de experiências práticas que o planejamento pode ser perfeito tecnicamente, mas se não se adaptar à realidade das instituições ou países onde é utilizado, pode ser desastroso. Houve então uma fase de ceticismo relacionada ao uso do planejamento, seguida de uma reformulação teórica que permitisse o bom uso do planejamento (ALMEIDA, 1999).

$\mathrm{Na}$ atualidade, seja em uma pequena empresa ou até mesmo em um país acentua-se a preocupação em implantar o processo de planejamento e adotar as técnicas e métodos mais adequados para sua operacionalização, incorporando-se na prática de todo administrador ou gestor moderno.

O planejamento ambiental tem características específicas que requerem métodos e técnicas adequados a sua efetivação. No início do século XX, a escola sociológica de Chicago iniciou estudos referentes ao entendimento da ecologia e da estrutura urbana. A partir daí e mais fortemente a partir da década de 60 
especialmente nos Estados Unidos da América têm sido experimentadas metodologias que possam dar conta da complexidade envolvida neste processo.

Almeida (1999) afirma que as metodologias utilizadas em planejamento ambiental podem ser divididas em duas linhas: a de demanda e a de oferta. Na linha de demanda, os estudos têm por objeto a população para definir os objetivos do planejamento. Na linha de oferta, os estudos têm por objeto o meio em que se desenvolvem as atividades da população.

Na linha de demanda destacam-se os seguintes métodos:

- Método de Lews (1964): surgiu de uma encomenda do Governo do Estado de Wisconsin (EUA) para a conservação ambiental no estado, em que os objetivos eram de harmonizar a riqueza natural com fatores introduzidos pelo homem promovendo um desenvolvimento adequado. Como dispunha de pouco tempo Lewis resolveu destacar elementos naturais mais importantes e maiores tais como, superfícies de água, terras úmidas e topografia notável. Ao mapear o estado verificou que estas estruturas formavam um espaço que poderia ser considerado continuo e daí surgiu a idéia de corredor ambiental. Estes elementos mais importantes e maiores eram separados daqueles que eram conseqüências de mudanças e adaptações ou acréscimos humanos aos recursos naturais (cidade antiga, cascatas, locais de banhos, etc.).

- Método de Steinitz (1967): na universidade de Harward, Carl Steinitz e seus colaboradores do Departamento de Landscape Arquitecture, Urban Design and Planning, elaboraram diferentes modelos matemáticos e técnicas automáticas capazes de dar uma resposta profissional ao problema de incorporação de dados físicos ao planejamento territorial. Esses dados, incorporados ao inventário do planejamento territorial são analisados 
determinando-se capacidades e vulnerabilidades do território para atividades variadas. Assim podem se melhorar as idéias primitivas e objetivas do plano.

- Método de Hills (1970): sendo um técnico florestal Hills respondeu a um pedido do Governo do Canadá para verificar se os recursos naturais estavam sendo utilizados em seu nível máximo compatível com as condições econômicas e sociais, e que ajustes poderiam ser feitos se isto não estivesse ocorrendo. Seu compromisso era criar uma estrutura científica para responder a estas solicitações. Criou então um sistema que pode ser resumido em dois pontos, a classificação do solo em unidades homogêneas e uma avaliação potencial destas unidades para usos múltiplos, alternativos ou combinados.

- Método de Lynch (1972): o autor de A imagem da cidade criou uma nova escola de urbanistas interessados em desenvolver técnicas capazes de abordar o urbanismo desde uma perspectiva integral, que entende como única forma de chegar a soluções racionais e consistentes, mediante intervenção de especialistas de diversas profissões. Seu método baseia-se na visão do território como um sistema de estruturas e superfícies, espaços, elementos viçosos, climas onde são consideradas as interações entre o organismo e seu entorno. Este método foi inovador ao considerar dados como o equilíbrio ecológico, a singularidade do local e qualidades intangíveis no planejamento territorial. Utilizavam-se técnicas de superposição de temas e análises utilizando a idéia de feed-back, o que garante o aperfeiçoamento de objetivos em um planejamento que é visto como um processo.

- Método de Johns (1973): na universidade de Manitoba - EUA, D. H. Johns e sua equipe elaborou um modelo muito complexo que inclui uma análise de capacidade intrínseca do território através de um inventário de dados 
detalhados, e um estudo de impactos produzidos por diferentes alternativas do planejamento territorial. Escolhe-se então a alternativa de menor impacto. $\mathrm{Na}$ linha de oferta destacam-se os seguintes métodos:

- McHarg (1969): considerado o pai da planificação ecológica, McHarg criou um sistema que consiste na aplicação dos conhecimentos do meio natural para planificar a localização e forma de desenvolvimento, utilizando-se de sistemas gráficos de sobreposição de mapas de recursos naturais e culturismo, bem como mapas de capacidade intrínseca e mapas de capacidades combinadas. A partir da descrição ecológica do lugar trata de avaliar as possibilidades de ordenação e planificação e suas conseqüências para o ambiente.

- Tricart (1972): os trabalhos de Tricart constituem uma aproximação ao problema de elaboração de mapas de critérios restritivos de proteção ao meio, frente ao planejamento potencial. O objetivo principal do método desenvolvido é recolher o conjunto de dados e informações científicas do meio natural que possam resultar na indicação de zonas ou fatores limitantes para determinados usos do território.

- Método de Falque ou Planejamento Ecológico de Falque (1975): M. Falque adaptou as idéias de McHarg na França decompondo algo mais a análise do território.

Quanto à escolha de um bom método para o planejamento ambiental um dos fatores mais importantes é a adequação no tempo e no espaço da metodologia mais apropriada. Na verdade o planejamento ambiental para cada região ou cidade é sempre único, visto que as características de ecossistemas e dos aspectos humanos são extremamente variáveis. As metodologias ajudam a adequar operacionalmente equipe, recursos e objetivos do plano para um resultado satisfatório. 
Em virtude do desenvolvimento de um histórico de experiências em planejamento ambiental desde a década de 1960, e a análise de seus erros e acertos o planejamento tem se convertido cada vez mais em um processo que privilegia a alimentação constante de um banco de dados, a possibilidade de alterações em objetivos ao longo do processo e a maior integração de dados, favorecendo o esforço de se atender a uma visão interdisciplinar.

\section{5 - Metodologia de Criação de Cenários Ambientais}

A metodologia utilizada para a proposição de diretrizes para o planejamento ambiental na região estudada será a do Processo de Criação de Cenários Ambientais, desenvolvida por Franco (2001) e já aplicada por outros pesquisadores como Vital (2003). Este método consiste em propor, a partir da caracterização da região estudada, cenários futuros para o desenvolvimento e o equilíbrio ambiental, sendo assim o planejamento não se torna um processo rígido, mas fluído, que pode ser constantemente revisitado.

\footnotetext{
"Pode-se chamar de Cenário Ambiental a projeção de uma situação futura, para o meio ambiente, tendo em vista a solução de um problema ou a melhora de uma condição presente, indesejável ou insatisfatória. Como a melhora de uma condição ambiental é um conceito que envolve aspectos socioculturais complexos e cuja mudança vai naturalmente implicar em conseqüências que envolverão toda uma comunidade, ela é antes de tudo uma decisão política. Assim sendo, é importante que na formulação de cenários ambientais haja a participação dos vários agentes sociais envolvidos num projeto. Logo, esse método de planejamento só é possível em uma sociedade democrática." (FRANCO, 2001. p.167)
}

Neste método os aspectos abordados normalmente para análise ambiental, tais como os aspectos ecológicos, econômicos, sociais e culturais, não se apresentam linearmente alinhados, mas configurando uma abordagem sistêmica e complexa, em que a parte está no todo e o todo está na parte. Assim as diretrizes 
propostas para o Planejamento Ambiental são mecanismos integrados de conservação e recuperação dos ecossistemas que consideram os aspectos ecológicos, econômicos e sócio-culturais (VITAL, 2003).

Os cenários propostos como possibilidade para o Planejamento Ambiental, segundo esta metodologia, estabelecem estratégias de ação, e não a predeterminação de ações, normalmente utilizada em programas de planejamento. Podem assim serem testadas inúmeras alternativas simultâneas para projetos de um mesmo processo de planejamento.

Os cenários ambientais nesta metodologia são representados por fluxogramas que consideram as estratégias de ação e os atores envolvidos nas mesmas, bem como a priorização de áreas e setores econômicos ou atividades.

Neste trabalho a idéia de utilização deste método vai ao encontro da verificação das características da região estudada, que apesar de potencialmente rica parece fazer escolhas políticas que podem levar a caminhos não pretendidos em termos de conservação ambiental. Apresentando-se cenários para a região de estudo pretende-se vislumbrar diretrizes importantes para seu desenvolvimento e estratégias de ações que ainda não são tratadas de maneira integrada. 
PARTE II

MONTANHAS E VALE: A SUSTENTABILIDADE NA BACIA HIDROGRÁFICA DO SAPUCAÍ 


\section{CAPÍTULO 3}

\section{A BACIA HIDROGRÁFICA DO SAPUCAÍ}

Água doce transformou-se em água amarga Numa lágrima que guarda A dor estranha das entranhas

Das montanhas das Gerais

No princípio foi um fio, foi riacho, depois rio Que cresceu e fez-se mar

E a terra machucada Chora a vida desmatada Que um dia irá secar

Pelos filhos chora a terra, $E$ essa dor descendo a serra Faz o vale fecundar

Dos índios Coroados, Índios hoje exterminados, Veio o nome que vigora

Nós herdamos dos Puris A mantiqueira, Aman ty kir Ou a "Montanha que Chora"

Água doce Transformou-se em água amarga Numa lágrima que guarda A dor estranha das entranhas Das montanhas das Gerais

(AMAN TY KIR, de Gildes Bezerra)

As fronteiras de uma cidade ou de uma região na maioria das vezes não são suficientes para se estabelecer as diretrizes para o planejamento ambiental nestes locais. As trocas energéticas, o equilíbrio da cadeia alimentar e a sustentação de florestas, rios e sistemas agrícolas e humanos que interagem e sustentam uma cidade ou um conjunto de cidades freqüentemente ultrapassa sua divisão políticoadministrativa. Além disto, a cultura, a história da ocupação de um determinado espaço geográfico, bem como suas relações econômicas e sociais influenciam, e, 
muitas vezes, determinam a situação de equilíbrio ou desequilíbrio ecológico do mesmo. Sendo assim, não é uma tarefa fácil estabelecer diretrizes para o planejamento ambiental em uma determinada cidade ou região. É necessário realizar diagnósticos abrangentes e precisos para que estejam disponíveis elementos suficientes para se fazer proposições.

Neste Capítulo pretende-se descrever a região onde se situa a bacia hidrográfica do Sapucaí e apresentar uma discussão das diretrizes do planejamento ambiental, para esta região. Para que isto ocorra pretende-se abordar diferentes escalas para análise da região, ou seja, pretende-se:

- Descrever e analisar a região da bacia hidrográfica do Alto e Médio Sapucaí, tendo como ponto de partida o estudo das áreas protegidas.

- Abordar questões históricas e culturais dos caminhos desta região.

- Descrever e analisar os programas de desenvolvimento para esta região.

- Avaliar como um fator de desenvolvimento a atividade turística, realizando uma análise dos circuitos turísticos existentes nesta região, tais como: a Rota Estrada Real, o Circuito Turístico Caminhos do Sul de Minas, o Circuito Terras Altas da Mantiqueira.

Estas tarefas têm como objetivo o entendimento das determinações geográficas, econômicas e históricas referentes à região estudada, realizadas de uma forma que permita dispor os principais elementos para a proposição de estratégias para o planejamento ambiental. 


\section{1 - Caracterização da Bacia Hidrográfica:}

\section{o Alto e Médio Sapucaí}

São apresentadas a seguir as principais características geográficas e históricas da Região da Bacia Hidrográfica do Sapucaí em sua porção alta e média.

A Bacia Hidrográfica do Rio Sapucaí integra a bacia do Rio Grande, localizando-se na região sudeste e atravessando dois estados, São Paulo e Minas Gerais. O Rio Sapucaí nasce na Serra da Mantiqueira, na cidade de Campos do Jordão-SP, a uma altitude de 1650 m, e deságua no Lago de Furnas a 780 m de altitude, atravessando, aproximadamente, 343 km (34 km dentro do Estado de São Paulo e 309 km em Minas Gerais). A parte mineira da bacia do Rio Sapucaí possui uma população estimada de 527.545 hab. e uma área de drenagem de 8.882 km² (http://www.igam.mg.gov.br/index.php, 2007).

O Rio Sapucaí é a artéria principal do corpo de 46 cidades, 43 no Estado Minas Gerais e 3 no Estado de São Paulo. Em sua Bacia vivem mais de meio milhão de pessoas (BERALDO, 1996).

A bacia hidrográfica do Sapucaí é uma sub-bacia do Rio Grande que, por sua vez pertence à Bacia do Prata, que após margear a Argentina deságua no Oceano Atlântico. A bacia do Sapucaí engloba as microregiões do Vale do Paraíba Paulista, Alto da Mantiqueira, Planalto Mineiro e Furnas (BERALDO, 1996).

Antes da construção da usina hidrelétrica de Furnas, no começo da década de 1960, o Rio Sapucaí desaguava diretamente no Rio Grande, nas proximidades de Alpinópolis-MG, e sua extensão era de 405 quilômetros (BERALDO, 1996).

O Rio Sapucaí nasce na Vila de Jaguaribe em Campos do Jordão-SP, na Serra da Mantiqueira e encerra seu curso na Vila de Pontalete, entre os municípios 
de Paraguaçú e Três Pontas, nesse local se une ao Rio Verde e juntos formam um braço da represa de Furnas.

O Rio está dividido em três fragmentos distintos: curso superior (Alto Sapucaí), curso médio (Médio Sapucaí) e curso inferior (Baixo Sapucaí). O Alto Sapucaí atinge uma área de 50 quilômetros, inicia na nascente em Campos de Jordão-SP e vai até a confluência com o Rio das Bicas próximo a cidade de Wenceslau Brás-MG. O Médio Sapucaí estende-se da confluência com o Rio Bicas até o encontro com o Rio Sapucaí Mirim em Pouso Alegre-MG. O Baixo Sapucaí, com 143 quilômetros, vai do encontro com o Sapucaí Mirim até a represa de Furnas (BERALDO, 1996).

Na região do Alto Sapucaí o grupamento das várias nascentes em Campos do Jordão dão forma ao rio ainda dentro do município. O rio segue serra abaixo rumo ao território mineiro. Nesta área ocorrem corredeiras, cachoeiras e em certos locais o rio é bem baixo atingindo apenas um metro de profundidade. Em território mineiro recebe os afluentes Itererê, Bicas e Santo Antônio e corre para a cidade de Itajubá.

Em Itajubá inicia-se a região do Médio Sapucaí. Desta cidade até Olegário Maciel, distrito do município de Piranguinho, o rio apresenta várias curvas e recebe nesta região os afluentes Piranguçu e Piranguinho, pela margem esquerda e o Rio Lourenço Velho, pela margem direita. Estes afluentes têm suas nascentes em terras de forte declividade, atravessam terras planas alcançando o Rio Sapucaí. Na altura do distrito de Olegário Maciel, na margem direita do Rio Sapucaí, encontra-se a Barra do Rio Alegre, outro afluente, proveniente da cidade de São José do Alegre. Este trecho apresenta região bastante cultivada. Após a Barra do Alegre as várzeas se alargam e as curvas são mais sinuosas. Nas proximidades de Santa Rita do 
Sapucaí, o rio recebe mais um afluente, o Ribeirão Vargem Grande, à esquerda, proveniente do município de Brasópolis. Depois de atravessar a cidade de Santa Rita do Sapucaí o rio dirige-se à cidade de Pouso Alegre, mudando a direção de oeste para norte, recebendo em uma grande curva o afluente Sapucaí-Mirim, proveniente das cidades de Santo Antônio do Pinhal-SP, Sapucaí Mirim-MG e São Bento do Sapucaí-SP. A partir deste trecho inicia-se o Baixo Sapucaí que termina seu trajeto na represa de Furnas (BERALDO, 1996).

Neste trabalho pretende-se adotar como área de estudo a região que vai do Alto ao Médio Sapucaí, incluindo seus afluentes.

No trecho Alto e Médio o Rio Sapucaí compreende em seu curso as cidades de: Campos do Jordão em São Paulo, Wenceslau Braz, Itajubá, Piranguinho, Santa Rita do Sapucaí e Pouso Alegre, em Minas Genais.

Para a classificação dos municípios como pertencentes ao Alto ou ao Médio Sapucaí utilizou-se a classificação da Associação dos Municípios da Micro Região do Alto Sapucaí (AMASP), que inclui Itajubá, apesar de parte deste município fazer parte do Médio Sapucaí. Também foi utilizada a classificação de Beraldo (1996). Assim neste trabalho coloca-se Itajubá como pertencente ao curso médio do Sapucaí, apesar de este fazer parte da AMASP.

Na tabela abaixo são apresentados os municípios da Bacia Hidrográfica do Sapucaí em sua porção alta e média, os trechos da bacia em que se encontram, os rios que abrigam e os estados da federação a que pertencem. 


\section{Municípios e Rios da Região da Bacia Hidrográfica do Alto e Médio Sapucaí}

\section{Município}

Campos do Jordão-SP
Wenceslau Braz-MG
Delfim Moreira-MG
Marmelópolis-MG
Maria da Fé-MG
Virgínia-MG
Pedralva-MG

Piranguçu-MG

São José do Alegre-MG

Santo Antônio do Pinhal-SP

Consolação

São Bento do Sapucaí-SP

Sapucaí Mirim-MG

Paraisópolis-MG

Conceição dos Ouros-MG

Cachoeira de Minas-MG

Gonçalves-MG

Itajubá-MG

Brasópolis-MG

Borda da Mata-MG

Cambuí-MG

Córrego do Bom Jesus

Estiva-MG

Santa Rita do Sapucaí-MG

Pouso Alegre-MG

\section{Rio}

Sapucaí

Sapucaí e Rio das Bicas

Santo Antônio

Lourenço Velho

Lourenço Velho

Lourenço Velho

Rio Anhumas que muda de nome na cidade de São José do Alegre, passando a se chamar Rio Alegre.

Rio Sapucaí

Rio Alegre

Sapucaí Mirim

Rio Itaim (afluente do Sapucaí-Mirim)

Sapucaí Mirim

Sapucaí Mirim

Sapucaí Mirim

Sapucaí Mirim

Sapucaí Mirim

Rio Campestre (afluente do SapucaíMirim)

Sapucaí e Lourenço Velho

Ribeirão Vargem Grande

Rio Mandú (afluente do Sapucaí)

Rio Itaim (afluente do Sapucaí-Mirim)

Rio Itaim (afluente do Sapucaí-Mirim)

Rio Itaim (afluente do Sapucaí-Mirim)

Sapucaí

Sapucaí e Mandú (afluente do Sapucaí)
AS

Trecho da Bacia

Hidrográfica

Alto Sapucaí (AS)

AS

AS

AS

AS

AS

AS

AS

AS

AS

AS

AS

AS

AS

AS

AS

Médio Sapucaí (MS) e AS (pela classificação da AMASP)

MS

MS

MS

MS

MS

MS

MS

Tabela 1: Municípios da região da Bacia Hidrográfica do Alto e Médio Sapucaí. 


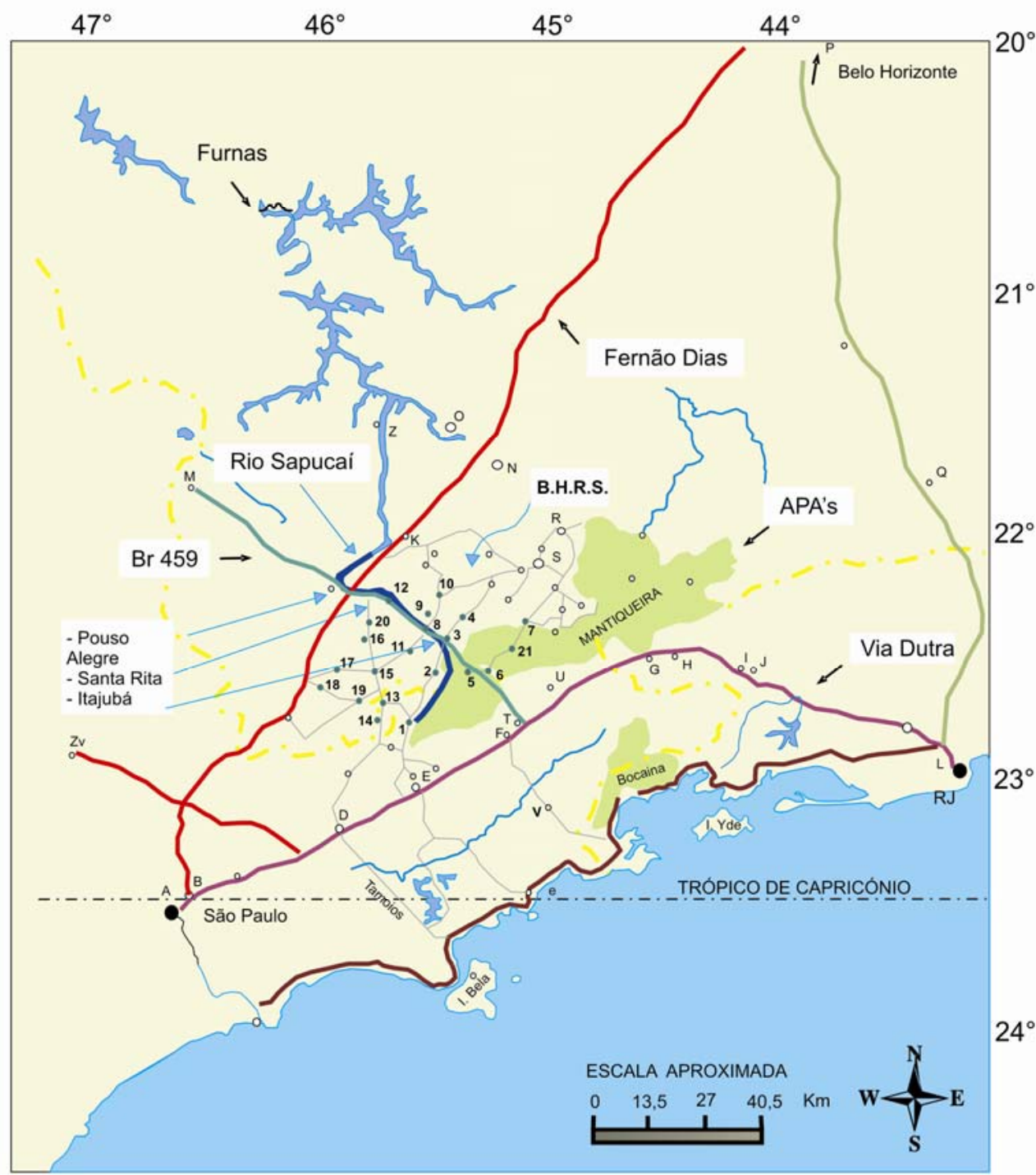

\section{MUNICÍPIOS DO ALTO E MÉDIO SAPUCAI}

1 - Campos do Jordão - SP

2 - Piranguçu

3 - Itajubá

4 - Maria da Fé

5 - Wenceslau Brás

6 - Delfim Moreira

7 - Virgínia

8 - Piranguinho

9 - São José do Alegre

10 - Pedralva

11 - Brasópolis

12 - Santa Rita do Sapucai

13 - São Bento do Sapucaí - SP

14 - Sapucai Mirim

15 - Paraisópolis

16 - Conceição dos Ouros

17 - Consolação

18 - Córrego do Bom Jesus

19 - Gonçalves

20 - Cachoeira de Minas

21 - Marmelópolis

\section{LEGENDA}

Municípios do Alto e Médio Sapucaí

Outros municípios

- Br 459

— Via Dutra

- $\mathrm{Br} 040$

_ Rodovia Rio-Santos

- Outras rodovias Limites Estaduais

Rio Sapucaí

APA's (Serra da Mantiqueira)

Elaboração: Helena M.

Fonte: Guia Quatro Rodas

\section{OUTROS MUNICÍPIOS}

D - São José dos Campos

$\mathrm{H}$ - Rezende

$\mathrm{N}$ - Três Corações

S - São Lourenço

E - Taubaté

I - Barra Mansa

O - Varginha

$\mathrm{T}$ - Lorena

F - Guaratinguetá

M - Poços de Caldas

$Q$ - Juiz de Fora

U - Cruzeiro

G - Itatiaia

R - Caxambu

V - Cunha

Mapa Esquemático do

Sudeste com Destaque para a Bacia Hidrográfica do Rio Sapucaí

Figura 2: Localização dos municípios da Bacia Hidrográfica do Rio Sapucaí no contexto do sudeste brasileiro. 


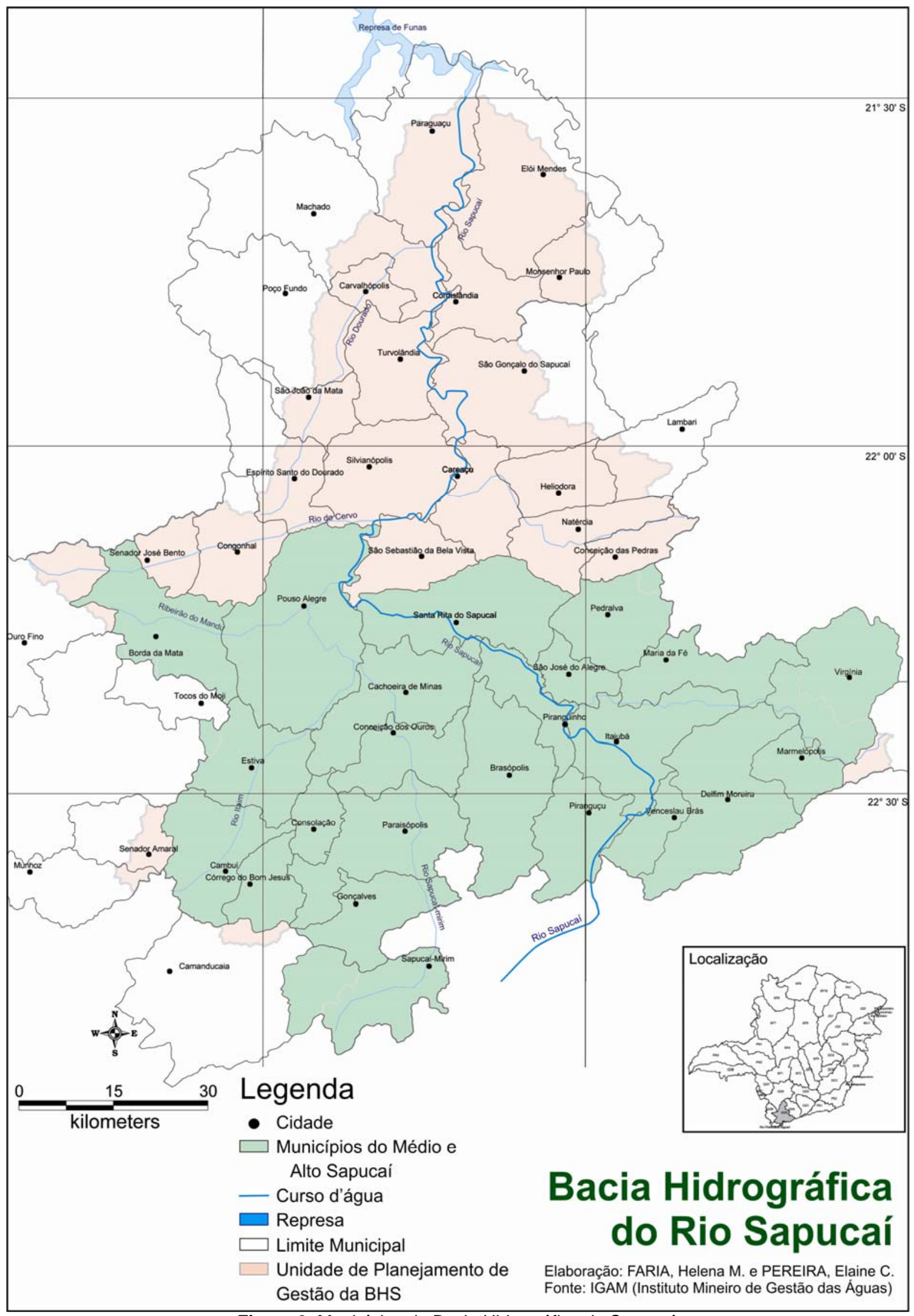

Figura 3: Municípios da Bacia Hidrográfica do Sapucaí. 


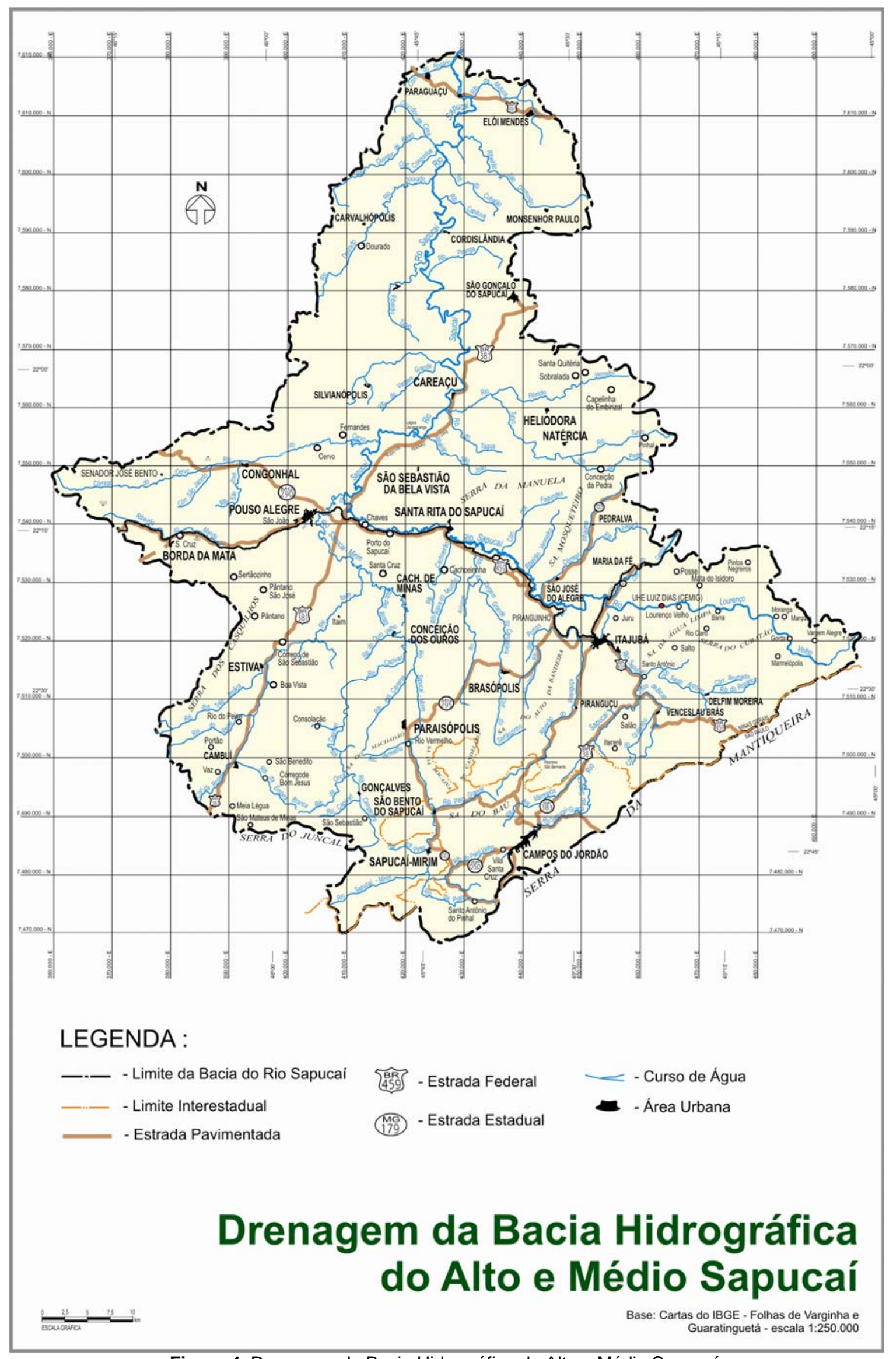

Figura 4: Drenagem da Bacia Hidrográfica do Alto e Médio Sapucaí. 
A proximidade da Bacia Hidrográfica do Sapucaí dos centros urbanos de economia mais expressiva do país faz da mesma uma área estratégica, em termos econômicos e ambientais, como destacado na figura 2.

A região do Alto Sapucaí esta localizada quase inteiramente, com exceção de um pequeno trecho próximo a cidade de Itajubá, dentro da APA (Área de Proteção Ambiental) da Serra da Mantiqueira. As características especiais desse vasto território dizem respeito a uma diversidade biológica que se aproxima da diversidade da Serra do Mar, inclusive com algumas espécies desta última. Além disso, é o território de espécies ameaçadas como o jacarandá e o pinheiro brasileiro ou araucária. Esta diversidade biológica inerente a Serra da Mantiqueira a coloca como reservatório de água e área de nascentes de diversas bacias hidrográficas importantes.

A região do Médio Sapucaí é composta de várzeas onde o Rio se alarga e as curvas são mais sinuosas e sujeitas à inundações. Os centros urbanos mais populosos que integram este trecho são Itajubá, Santa Rita do Sapucaí e Pouso Alegre. As cabeceiras dos rios Sapucaí Mirim e Itaim que deságuam no Médio Sapucaí também apresentam paisagens típicas da Serra da Mantiqueira.

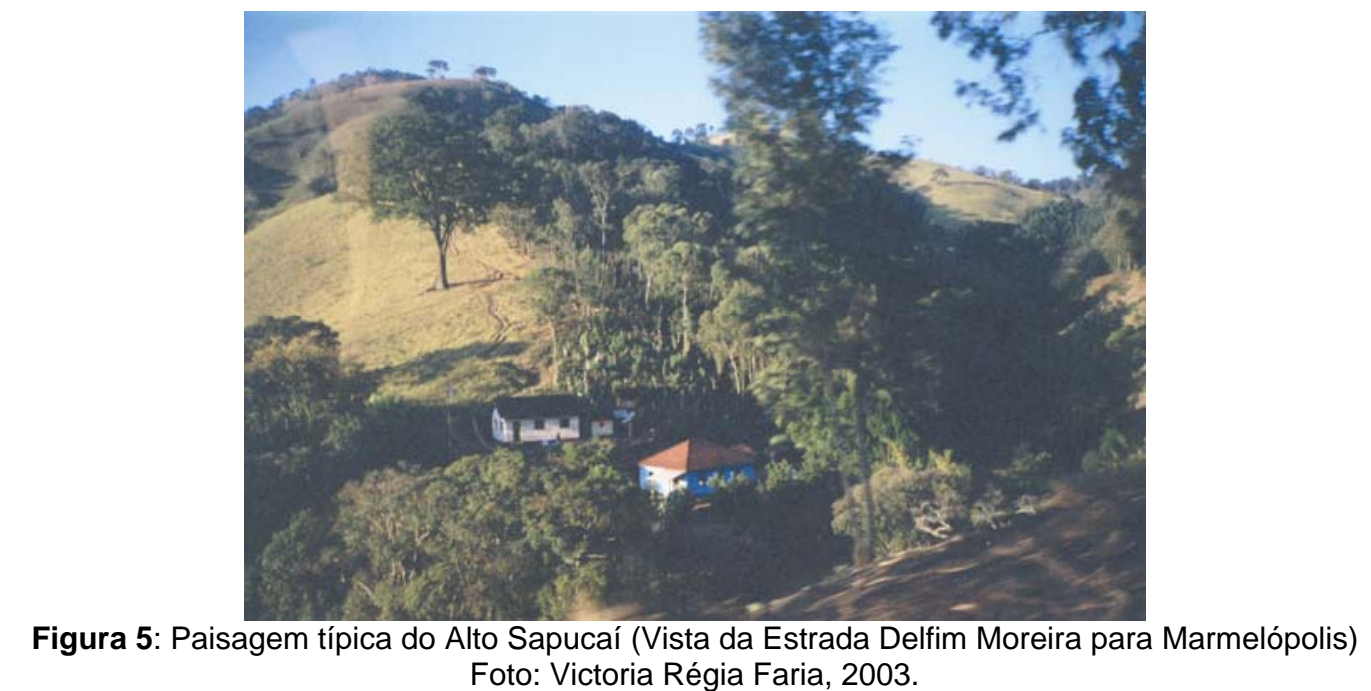




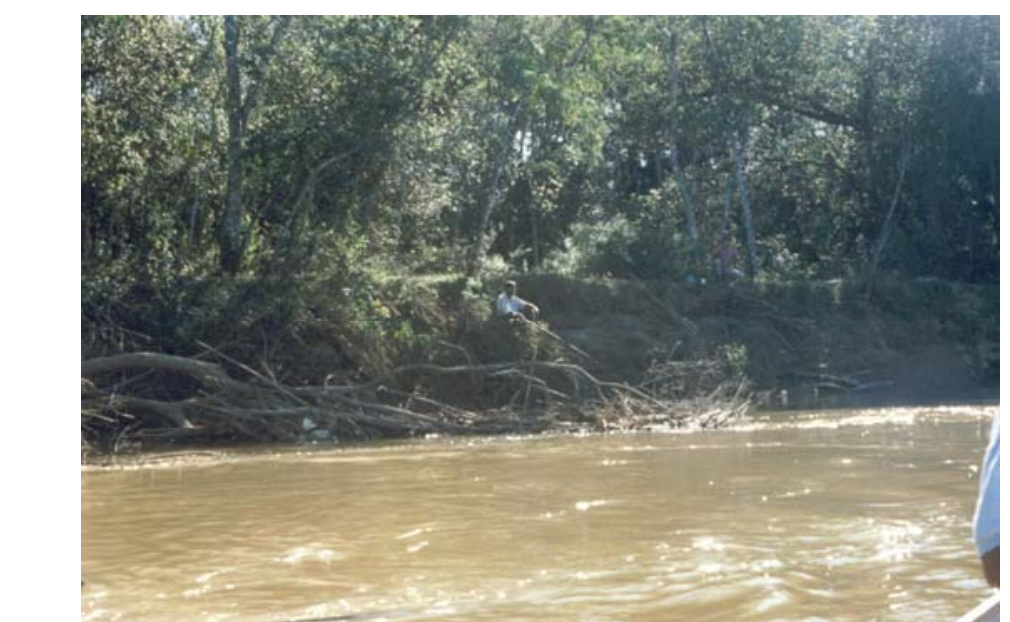

Figura 6: Paisagem típica do Médio Sapucaí (Rio Sapucaí em Piranguinho). Foto: Helena M. Faria, 1998.

\subsection{1 - Impactos Ambientais ao longo da Bacia Hidrográfica do Sapucaí: equilíbrio ambiental ameaçado}

Cerca de cem anos de ocupação humana fizeram com que o Rio Sapucaí e seus afluentes perdessem quase toda sua riqueza de espécies originais e a paisagem fosse extremamente modificada.

Em determinados trechos o Rio Sapucaí chega a ter 50 metros de largura, nestes pontos a mata ciliar deveria ter cem metros de largura, segundo a legislação brasileira, o que não ocorre na prática, sendo que pouquíssimas faixas apresentam áreas preservadas nestas dimensões (BERALDO, 1996).

O desmatamento começou com o povoamento da região e persiste, sendo que na atualidade as atividades que mais contribuem para o desmatamento são: instalação de olarias, dragas de areias e outros minérios e a atividade agropecuária, além da existência de cidades inteiras as margens do Sapucaí, como Itajubá e Santa Rita do Sapucaí, onde o rio está praticamente encravado em sua zona urbana.

No que se refere aos problemas ambientais destacam-se, dentre outros, a realização de queimadas, o desmatamento, que compromete as matas ciliares, e a 
contaminação dos cursos de água por efluentes industriais. Segundo dados do IGAM (Instituto Mineiro de Gestão da Águas) o Índice de Qualidade das Águas no Rio Sapucaí apresentou melhora em pontos situados a montante e a jusante da cidade de Itajubá, onde o IQA Médio e Ruim das águas em 2004 passou para IQA Bom e Médio em 2005, respectivamente. Já o Rio Sapucaí-Mirim manteve o resultado de IQA Médio verificado em 2004 (http://www.igam.mg.gov.br/index.php).

O Médio Sapucaí é afetado por enchentes periódicas que deixam marcas na economia e na cultura local. As principais cidades afetadas são Itajubá, Santa Rita do Sapucaí e Pouso Alegre. Após uma grande enchente no ano 2000 algumas iniciativas foram tomadas tais como: a limpeza e alargamento da calha do Rio Sapucaí, e a manutenção de sistemas de alerta de cheias. Mas estas medidas não têm sido eficazes para se evitar as cheias, pois as cidades situam-se na planície de inundação do Rio Sapucaí.

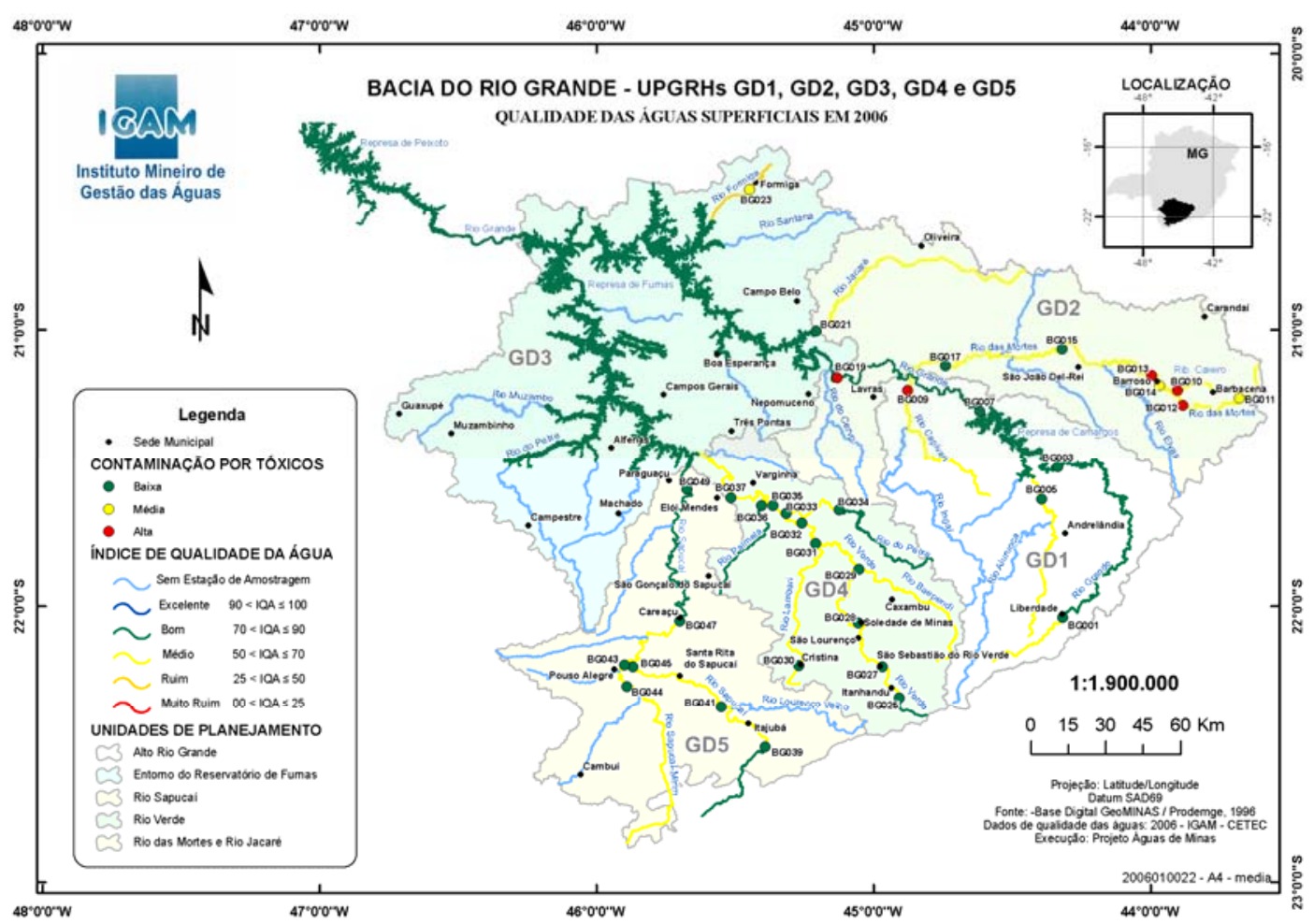

Figura 7: Bacia do Rio Grande: qualidade das águas em 2006 Fonte: IGAM (Instituto Mineiro de Gestão das Águas), http://www.igam.mg.gov.br, 2007. 


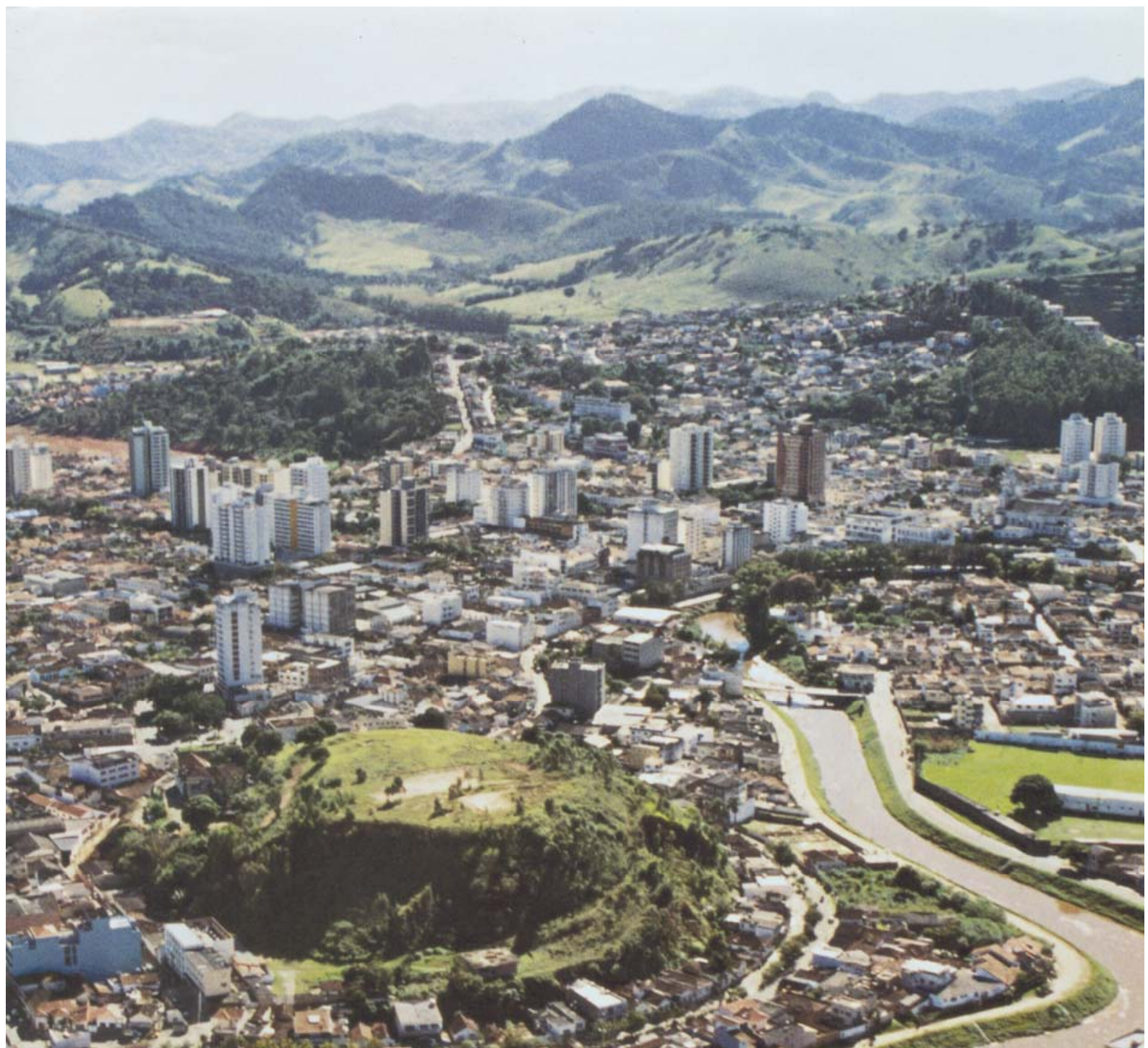

Figura 8: Itajubá-MG e o Rio Sapucaí. Fonte: panfleto Vestibular Unifei, 2003.

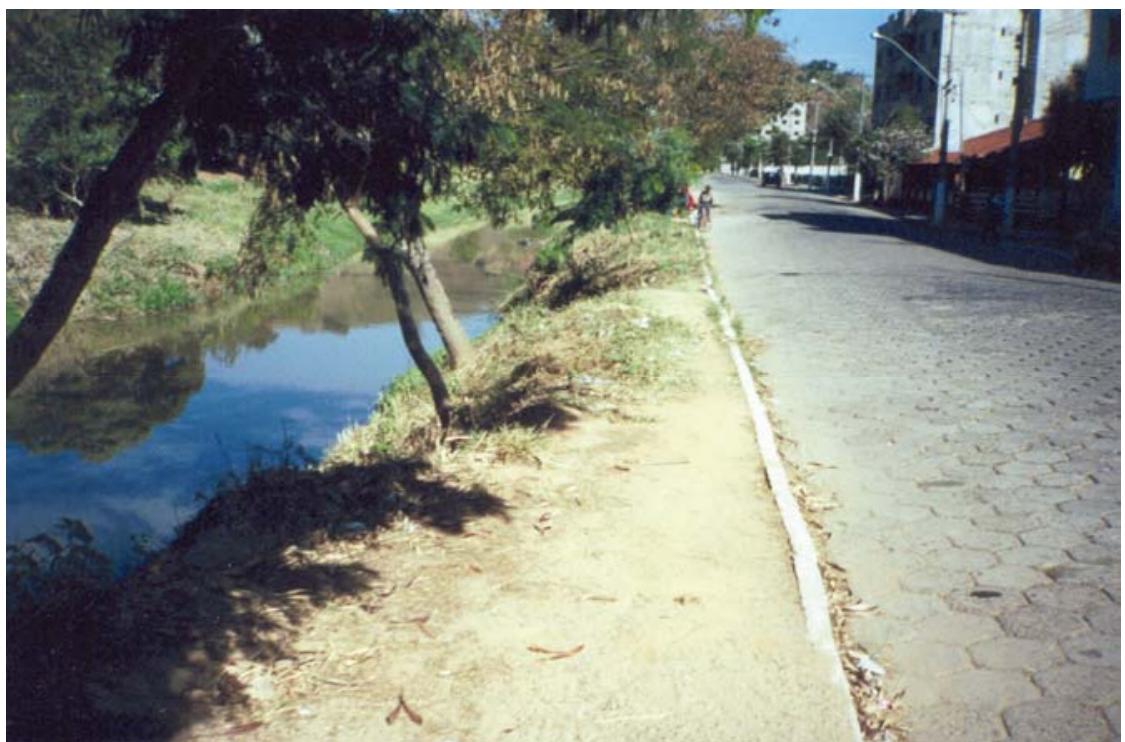

Figura 9: Trecho do Rio Sapucaí em Itajubá, 2001. Antes de intervenção de alargamento. Foto: Helena M. Faria. 


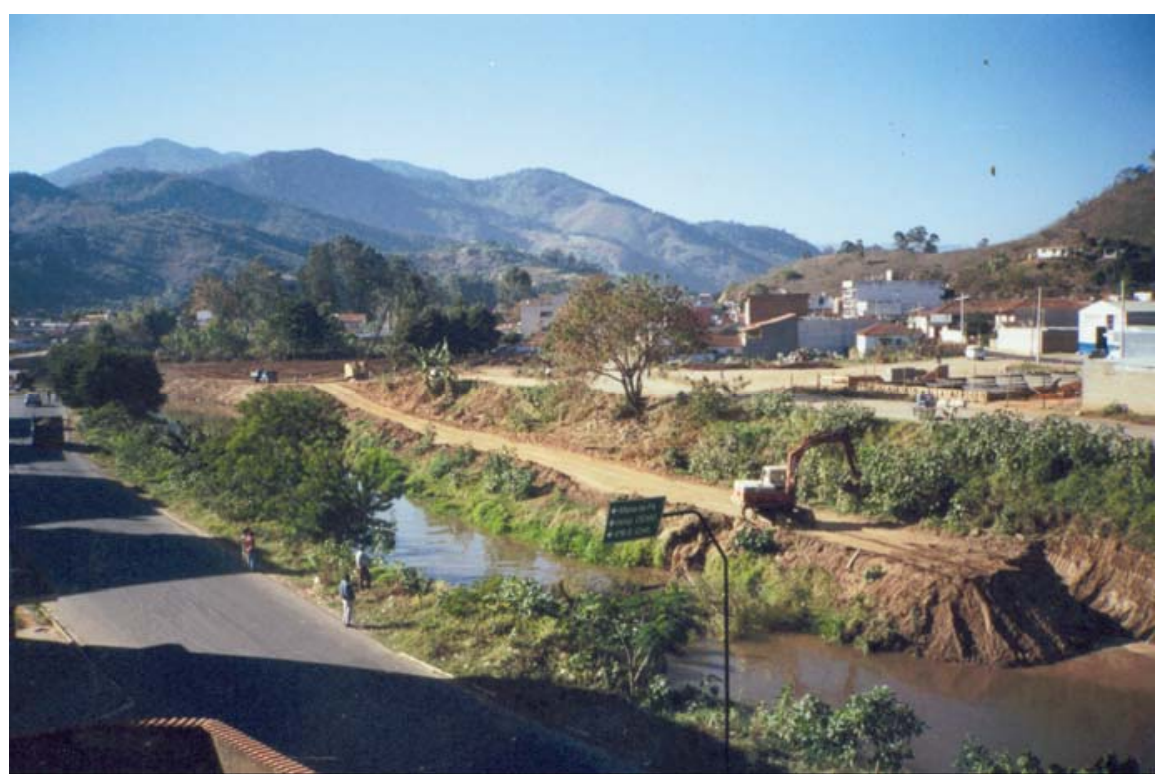

Figura 10: Intervenção no Rio Sapucaí em Itajubá-MG realizada em 2001 após uma grande enchente no ano de 2000. Foto: Helena M. Faria.

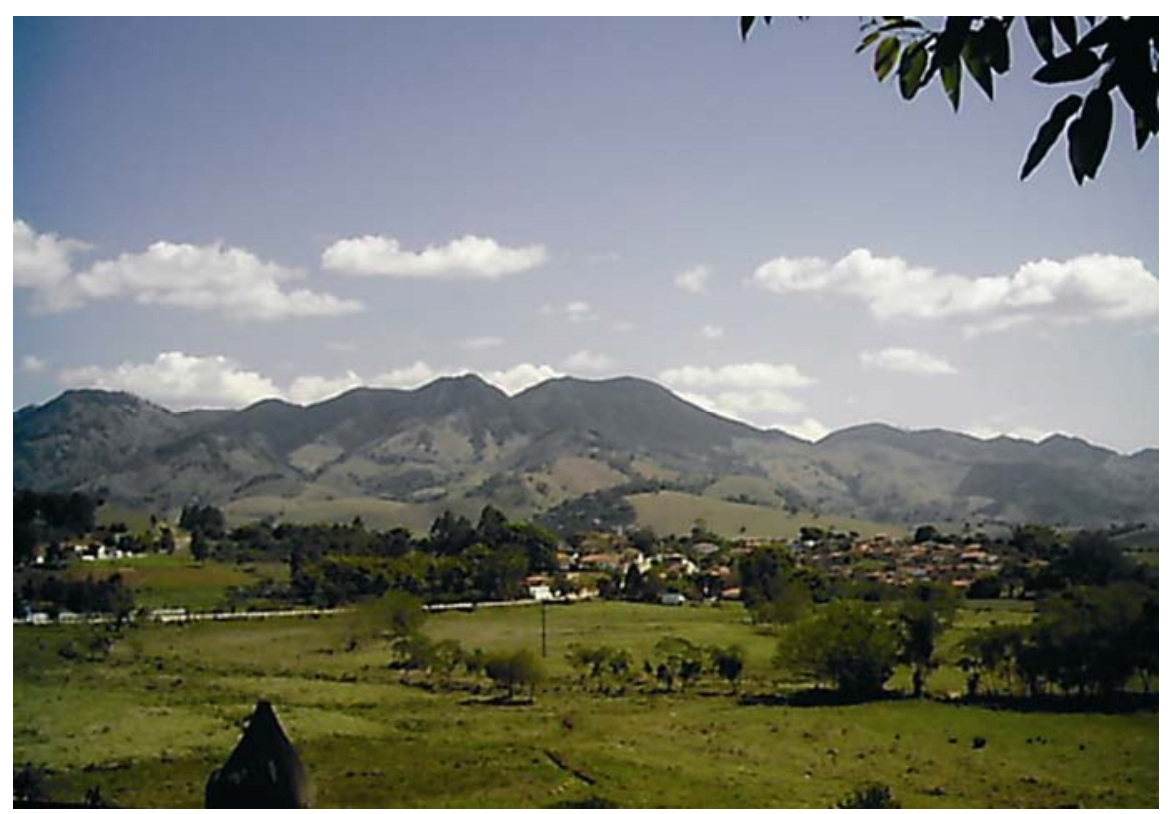

Figura 11: Vista da Cidade de Virgínia. Foto: Elaine C. Pereira, 2007.

\subsubsection{1 - Vegetação e Fauna: a Sapucaia que deu origem ao nome do rio não existe mais em suas margens}

Matas, campos e cerrado formavam a vegetação primitiva do Sul de Minas e da Bacia do Sapucaí. Da mata atlântica mineira restou apenas manchas que ocorrem principalmente na Serra da Mantiqueira, onde o rio nasce. Ao longo do 
Sapucaí a mata atlântica aparece sob a forma de mata ciliar também chamada de mata de galeria (BERALDO, 1996).

Na floresta de Araucárias que ocorre no Alto Sapucaí, existem trechos mais preservados, e que ainda assim, não são suficientes para que o equilíbrio e a manutenção da biodiversidade seja efetiva. Os pinheiros do Brasil (Araucária) ocorrem nas paisagens dos municípios de Campos do Jordão, Delfim Moreira, São Bento do Sapucaí, Santo Antônio do Pinhal, Wenceslau Brás, Sapucaí Mirim e Gonçalves. Em certos recantos de mais altitude a floresta cede lugar à vegetação rupestre, que se desenvolve nos rochedos (BERALDO, 1996).

Nos municípios de Itajubá, Santa Rita do Sapucaí, Pouso Alegre, no Médio Sapucaí até o município de Careaçú, já no curso baixo da bacia, predomina uma vegetação de campos que foi se transformando em pastagem, com pouca presença de árvores. No curso do Baixo Sapucaí aparece uma vegetação do tipo cerrado, também já bastante modificada pelos usos e ocupações humanas.

A vegetação do tipo Capoeira, uma espécie de regeneração das florestas primitivas, aparece em vários trechos do Rio Sapucaí.

As Sapucaias, espécies que deram nome ao rio desapareceram de suas margens e não florescem mais. Esta espécie da família da lecticidáceas produz frutos oleosos e comestíveis, semelhantes à castanha-do-pará. Sua madeira dura, pesada e resistente foi usada na construção de dormentes, construção civil e naval. Em tupi iasapuka'i, significa "fruto que faz saltar o olho", que "grita", que "canta". Seu desmatamento teve como causa o uso desta madeira para obras externas e durante o desmatamento na procura por outras madeiras-de-lei (BERALDO, 1996).

No diagnostico Ambiental do Estado de Minas Gerais, estão relacionadas como espécies presentes na região da bacia hidrográfica do Sapucaí 82 espécies do 
cerrado e 149 que ocorrem nos diversos tipos de matas, inclusive nas ciliares. (BERALDO, 1996).

Algumas das espécies de fauna terrestre nativas da região são: onça, jaguatirica, paca, capivara, jacaré, anta, lobo, porco-do-mato, ouriço.

Em vários trechos ao longo do rio, nos brejos, ainda habitam garças, colhereiros, marrecos, mergulhões, biguás, seriemas e outras aves ribeirinhas. E alguns pontos também aparecem tucanos.

A fauna aquática é atualmente muito reduzida se comparada a original que apresentava espécies como: dourado, surubi, jaú, lambari, traíra. Atualmente estas espécies aparecem muito raramente e quando aparecem não têm o tamanho adequado para pesca. A extinção e a diminuição da quantidade destas espécies de peixes do Rio Sapucaí foi responsável pelo desaparecimento de uma categoria de trabalhadores que durante muito tempo subsistiu às suas margens: os pescadores. Estas transformações foram causadas pela ocupação urbana, industrial e agropecuária que também afetou a vegetação ao longo da bacia.

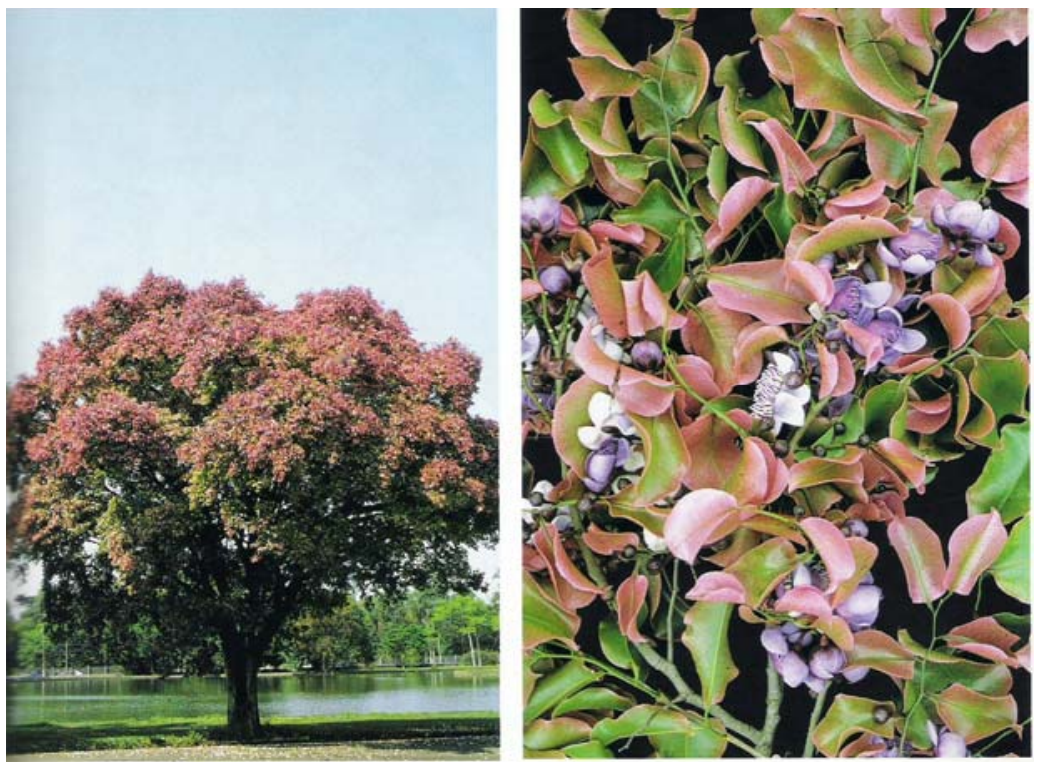

Figura 12: Sapucaia, planta que deu origem ao nome do Rio Sapucaí. Fonte: Lorenzi, 2002. p.156 


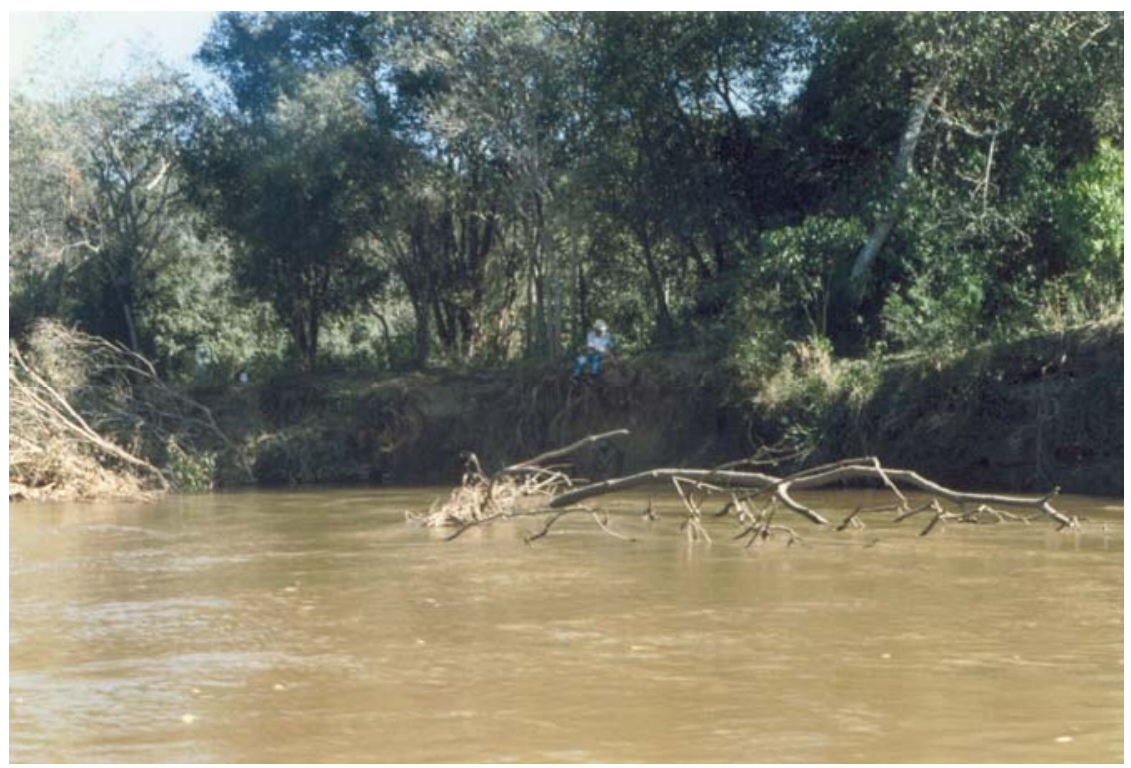

Figura 13: Trecho do Rio Sapucaí com mata ciliar entre Piranguinho e Santa Rita do Sapucaí. Foto: Izabel M. Faria, 1998.

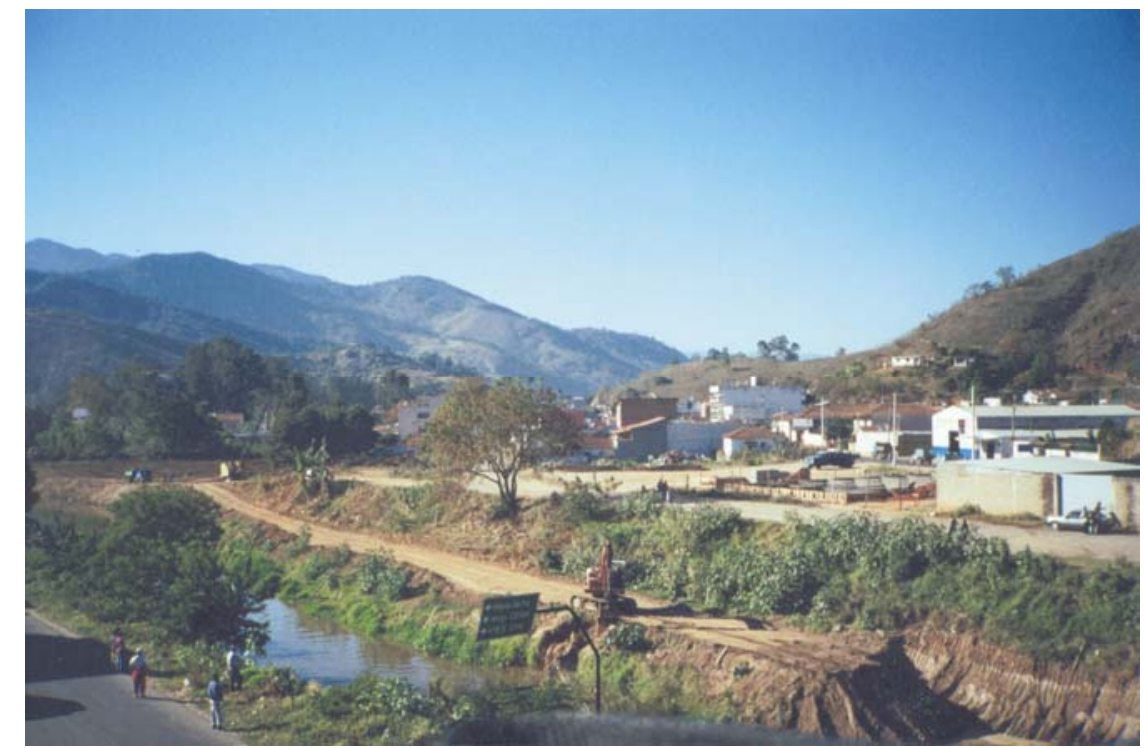

Figura 14: Mata ciliar na área urbana de Itajubá no ano de 2001 sendo derrubada pela intervenção de alargamento da calha principal do Rio. Foto: Helena M. Faria.

\subsection{2 - Gestão da Bacia Hidrográfica no Alto e Médio Sapucaí a partir da legislação referente aos recursos hídricos existentes}

A legislação brasileira referente aos recursos hídricos prevê que a gestão das águas seja feita através de um comitê formado por representantes dos municípios que compõem a bacia. 
Pelo decreto número 39.911, de 22 de setembro de 1998, o governo do Estado de Minas Gerais instituiu o Comitê de Bacia Hidrográfica do Sapucaí que tem como finalidade a promoção da viabilidade técnica e econômico-financeira de programas de investimentos e consolidação de políticas de estruturação urbana e regional visando o desenvolvimento sustentável na área da bacia.

No caso da Bacia Hidrográfica do Sapucaí, o comitê formado abrange somente os municípios mineiros, pois os paulistas se organizaram em outro comitê, que é o do Rio Sapucaí Mirim. Assim fazem parte do Comitê da Bacia Hidrográfica do Sapucaí, os seguintes municípios: Borda da Mata, Brasópolis, Cachoeira Paulista, Camanducaia, Cambuí, Careaçu, Carvalhópolis, Conceição das Pedras, Conceição dos Ouros, Congonhal, Consolação, Cordislânica, Córrego do Bom Jesus, Delfim Moreira, Elói Mendes, Espírito Santo do Dourado, Estiva, Gonçalves, Heliodora, Itajubá, Lambari, Machado, Maria da Fé, Marmelópolis, Monsenhor Paulo, Natércia, Ouro Fino, Paraquaçu, Paraisópolis, Passa-Quatro, Pedralva, Piranguçu, Piranguinho, Poço Fundo, Pouso Alegre, Santa Rita do Sapucaí, São Gonçalo do Sapucaí, São João da Mata, São José do Alegre, São Sebastião da Bela Vista, Sapucaí Mirim, Senador Amaral, Senador José Bento, Silvianópolis, Turvolância, Wenceslau Brás e Virgínia.

O Comitê de Bacia Hidrográfica do Sapucaí está em funcionamento e tem sede em Itajubá.

Além do Comitê de Bacia existem outras associações atuantes na região estudada como a AMASP (Associação dos Municípios da Microrregião do Alto Sapucaí) e a Associação dos Municípios do Médio Sapucaí. 


\subsection{3 - História}

O Rio Sapucaí foi descoberto em 1596, pelo sertanista João Pereira Botafogo. Durante os séculos XVII e XVIII serviu de rota para bandeira em busca do ouro. Até o princípio do século XIX viviam às margens do Sapucaí indígenas das tribos Puris e dos Coroados. No século XIX era navegável se configurando como importante rota comercial na região (PEREIRA, 2003).

No século XIX a região do Rio Sapucaí e grande parte da Região Sul Mineira era navegável, inicialmente com embarcações movidas a varejão (balsas impelidas por varas grandes). Por volta de 1892 surgem barcos à vapor. O primeiro vapor a descer as águas do Sapucaí chamava-se Guapy. Em 1919 surge a Navegação Fluvial do Sapucahy, empresa subsidiada pelo Estado que possuía itinerário e horários regulares. Em todo o seu percurso os barcos à vapor passavam em 12 portos. A última viagem dos barcos à vapor da empresa Navegação Fluvial do Sapucahy ocorreu em 1933 (BERALDO, 1996). Outras embarcações ainda persistiram e continuaram a transitar até 1940. Nesta faze a navegação contribuiu muito para o desenvolvimento econômico da região do Sul de Minas, escoando produtos para comercialização, dos pequenos povoados para as cidades maiores.

O transporte na região era complementado por uma Linha Férrea denominada Viação Férrea do Sapucaí. Aberta como Estrada de Ferro do Sapucaí em 1887, inaugurou o primeiro trecho de linha até Itajubá em 1891, partindo de Soledade, na Estrada de Ferro Minas e Rio. Em 1897 chegou ao Sapucaí, na divisa com São Paulo, tendo cedido o trecho que chegava a Itapira à Mogiana bem antes disso. Incorporada pela Rede Sul-Mineira em 1910. Os trens de passageiros deixaram de circular no final dos anos 70 e os trilhos foram retirados a partir de 1986 . Junto à 
estação de Porto Sapucaí, partia o barco que fazia o transporte de cargas e de passageiros pelo rio Sapucaí.

No ano de 1959 dois engenheiros das Centrais Elétricas de Minas Gerais (CEMIG) pesquisavam o Rio Grande, foz do Sapucaí. Um deles encontrou uma paisagem diferente numa imensa curva do rio: era um canyon longo, imenso conhecido como "Corredeira de Furnas" (BERALDO, 1996).

Anos mais tarde esta descoberta contribuiu para que fosse criada a Companhia Hidrelétrica de Furnas, que impulsionada pela demanda crescente por energia no Brasil e pelas políticas do então Presidente da República Juscelino Kubitscheck de Oliveira, determinou a construção daquela que viria a ser por muitos anos, a maior hidrelétrica da América do Sul.

Antes da construção da grande represa de Furnas, o Sul de Minas era abastecido de energia por pequenas centrais hidrelétricas que pertenciam à Companhia Sul Mineira de Eletricidade, que geravam menor impacto ambiental, apesar de o sistema não ser tão eficiente e gerar blecautes frequentemente.

A construção da represa de Furnas encobriu a foz do Sapucaí, inundando 1440 quilômetros do Sul de Minas. A usina começou a operar em 1963, mas foi no dia 09 de janeiro de 1961 que ela fechou suas comportas para o início do enchimento do reservatório de água. Localidades como São José da Barra, Guapé, Fama e as estações de Pontalete e Santo Hilário praticamente desapareceram. As áreas inundadas eram restituídas aos moradores através de restituição financeira ou da reconstrução. Relatos dos moradores da região mostram que estes não ficaram satisfeitos com a construção da represa destacando como perdas irreparáveis aquelas relacionadas à memória dos lugares, perdas dos solos e da biodiversidade. 
As cidades inundadas recebem royalts como forma de compensação pelos prejuízos sofridos, mas mesmo assim o número de descontentes foi grande.

O vale do Sapucaí possui cerca de 62 mil hectares de várzeas, sendo que 50\% destas sofrem inundações periódicas. Na década de 1980 houve estudos e projetos para se criar um sistema de controle de cheias, aliado à irrigação ao longo do vale do Sapucaí (Médio Sapucaí), mas que acabou ficando esquecido pela sucessão de governos que privilegiaram outras atividades. (BERALDO, 1996).

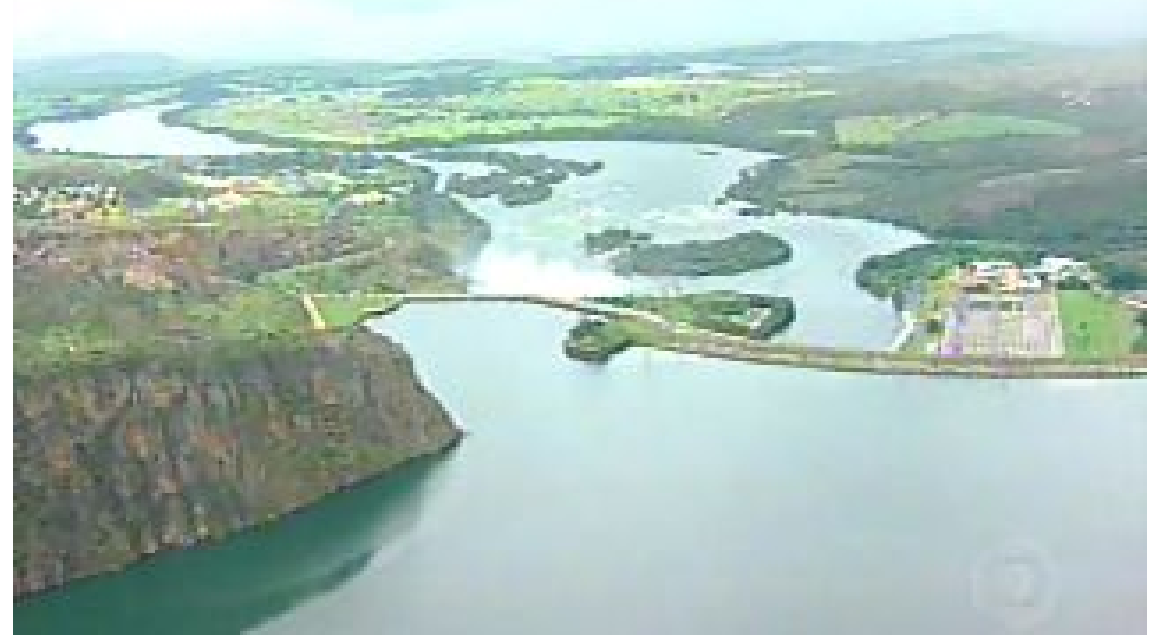

Figura 15: Represa de Furnas. Fonte: www.terrademinas.com.br

\section{2 - Áreas protegidas na Serra da Mantiqueira e Alto Sapucaí}

A existência de áreas específicas destinadas à conservação ambiental nas cidades ou em determinadas regiões é uma política freqüente para se alcançar os objetivos do planejamento ambiental. Mas não é a única atividade a ser feita, são necessárias outras, tais como: a educação ambiental, a revisão de padrões de comportamento e de utilização de produtos tóxicos, a política industrial, as atividades de saneamento e de composição da paisagem urbana, as diretrizes para o uso e a ocupação do solo, entre tantas outras. Aqui, apresenta-se uma discussão 
das relações entre as áreas protegidas e o equilíbrio ambiental nos municípios da região da bacia hidrográfica do Alto e Médio Sapucaí.

A partir de dados da história da ocupação do território, das perspectivas políticas existentes e do estudo das Unidades de Conservação e outras áreas protegidas existentes na região, pretende-se avaliar a situação destas áreas na atualidade e sua contribuição para o planejamento ambiental.

\subsection{1 - A Serra da Mantiqueira}

A Serra da Mantiqueira compõe geologicamente com a Serra do Mar e o Vale do Rio Paraíba do Sul um conjunto tectônico singular entre os grandes sistemas de montanha do globo. Seu surgimento vem de um cataclismo natural ocorrido há cerca de cento e cinqüenta milhões de anos, quando houve a separação do que conhecemos hoje como América do Sul e África, com o surgimento do Oceano Atlântico. (COSTA, 1987).

Olhando-se do mar em direção ao continente, a meio caminho entre São Paulo e Rio de Janeiro vêem-se dois grandes degraus, o primeiro a Serra do Mar em segundo plano atrás do primeiro, a Serra da Mantiqueira, que formam um conjunto relativamente paralelo entre si. A Serra do Mar se estende desde a margem esquerda do Rio Itajaí, no Estado de Santa Catarina, até a margem direita do Rio Paraíba do Sul, na cidade de Campos, no Estado do Rio de Janeiro. A Serra da Mantiqueira tem seu extremo meridional localizado ao norte da cidade de São Paulo e seu extremo setentrional localizado à margem direita do Rio Doce no Estado do Espírito Santo. O sistema Mantiqueira apresenta um conjunto de leques que 
penetram pelo interior de Minas Gerais, estendendo-se pelo Vale do Rio Doce. (COSTA, 1987).

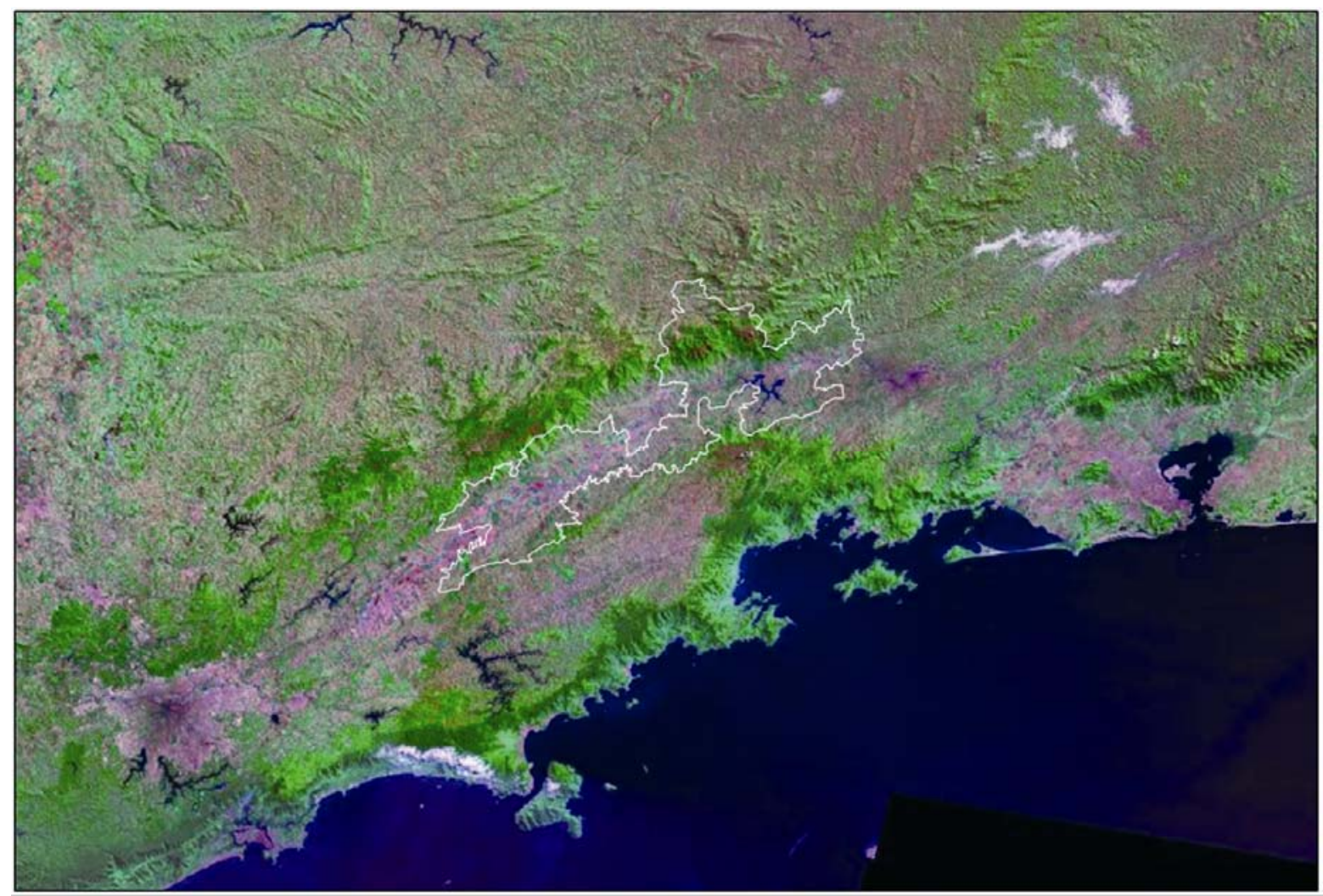

Figura 16: Imagem de satélite da Serra da Mantiqueira e contorno da APA. Fonte: IBAMA/FNMA. 2003.

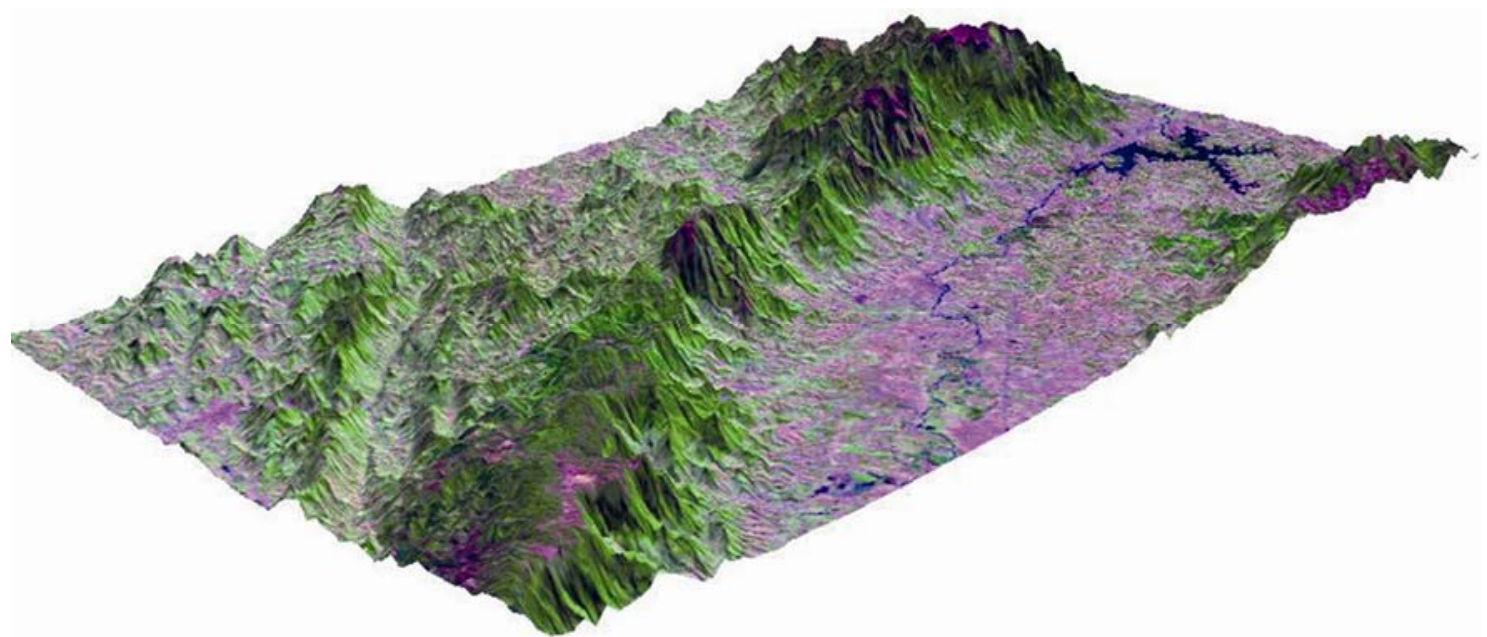

Figura 17: Imagem de satélite da Serra da Mantiqueira em perspectiva. Fonte: IBAMA/FNMA. 2003. 


\subsection{2 - Relevo, Clima e Vegetação na Mantiqueira e no Alto Sapucaí}

As observações aqui apresentadas têm como fonte o trabalho de Costa (1987) sobre Aiuruoca e Matutu em que este autor faz um estudo amplo, discorrendo sobre as características da Mantiqueira.

A Serra do Mar mostra em sua extensão flora relativamente uniforme, classificada como "mata higrófila tropical" ou "subtropical", de acordo com as condições climáticas predominantes. A Serra da Mantiqueira por sua vez na altura da Bocaina, corre quase paralela à Serra do Mar, e a curta distância entre elas explica a notável concordância de suas vegetações, especialmente em áreas de cotas mais baixas.

As chamadas "matas atlânticas" ou "matas higrófilas tropicais ou subtropicais" ocorrem na zona costeira do Nordeste ao Sul do Brasil. A Serra do Mar é a região de maiores precipitações do Brasil, onde as condições de calor, umidade e luz são extremamente vantajosas para a vegetação. A alta umidade deve-se ao encontro dos ventos alísios com as montanhas. A Serra da Mantiqueira, situada um pouco mais para o interior e um pouco mais elevada também se beneficia deste fenômeno, sendo que a origem do nome Mantiqueira em tupi, remete a este fenômeno, significando lugar onde a chuva goteja.

A vegetação na Mantiqueira, graças à insolação que ganha intensidade pela distribuição em degraus das matas nas encostas, permite que as árvores poupem o esforço de crescer desmesuradamente em busca de luz e desenvolver troncos grossos, projetando logo seus galhos desde uma altura menor, formando copadas densas.

A mata atlântica caracteriza-se também pela ampla variedade de espécies vegetais, que se desenvolvem em habitats diversos propiciados pelo relevo dessa 
extensa região serrana. Grande parte da drenagem do planalto ocorre por essa faixa costeira, modelando o terreno com os caminhos das águas.

A mata atlântica é uma floresta de troncos retos com altura média de vinte a trinta metros, bastante densa e encerra constantes sub-bosques. São comuns palmeiras, xaxins e taquaruçus, lianas e epífitos superiores, sendo que para cada categoria vegetal há uma grande variedade de espécies.

Aproximadamente a mil metros de altitude começa uma mata de transição. Acima desta altitude algumas espécies desaparecem e são substituídas por outras muitas vezes semelhantes e do mesmo gênero.

A partir de 1.600 metros no lado ocidental da Mantiqueira e de 1.900 metros no lado oriental, de acordo com as condições ecológicas da serra, inicia-se a zona do pinheiro-do-paraná (Araucária angustifólia). A vegetação nessa área é composta, além desta conífera, por espécies características do planalto, segundo os micro climas que prevalecem em cada área.

Acima de 2.000 metros a vegetação se torna arbustiva, mudando consideravelmente seu aspecto geral. Formam-se vazios onde aparecem plantas baixas, conforme a altitude aumenta. Aparecem campos nas lombadas da serras e mata nas grotas, representando uma das mais belas expressões da paisagem brasileira.

Acima de 2.400 metros até os picos culminantes, a Mantiqueira apresenta na sua superfície, uma vegetação de liquens, mais ou menos ricas conforme a insolação e as condições ecológicas. Estes liquens aparecem associados ou substituídos por musgos. As ranhuras de rochas e as fendas podem apresentar um tufo de vegetação, compondo uma flora rara, com ocorrência de endemismos de grande valor. 


\section{O Alto Sapucaí}

O Alto Sapucaí está situado, em sua maior parte, na Serra da Mantiqueira, em terrenos de formação cristalina. O relevo é caracterizado pela alta declividade e pela amplitude topográfica, resultando na presença de vales, montanhas e picos (ANDRADE, 2003).

Segundo Andrade (2003) o clima, tropical de altitude, possui verões brandos e chuvas concentradas nesta estação. A amplitude topográfica exerce influência no clima da Serra da Mantiqueira. O clima, nas áreas elevadas é mais frio, com freqüente formação de geadas no inverno. Ocasionada pela expressiva amplitude topográfica e as influências climáticas, na Serra da Mantiqueira ocorre o zoneamento vertical da vegetação, tendo espécies da floresta tropical de encosta como palmeiras e ipês; da mata subcaducifoliada de araucárias como o pinho-bravo e guatambu; e de campos de altitude como o junco. Nas áreas mais elevadas há freqüência de musgos, liquens e bromélias, ocasionadas pela alta umidade.

Nas áreas de menor altitude, como nos municípios de Piranguinho e Conceição dos Ouros, a vegetação, típica da floresta tropical de encostas, apresenta maior variedade e adensamento de espécies que as encontradas nas matas de araucárias ou nos campos de altitude (ANDRADE, 2003).

As matas subcaducifoliadas com Araucárias ocorrem na maior parte dos municípios da área de estudo, em localidades de expressiva altitude, como o Sertão do Cantagalo em Gonçalves e Pintos Negreiros em Maria da Fé, entre outras. Nestas áreas há maior homogeneização das espécies vegetais, predominando a araucária e o pinho-bravo.

A vegetação de campos de altitude ocorre nos pontos mais altos da Serra Mantiqueira, como nos bairros rurais do Campestre em Gonçalves, do Charco em 
Delfim Moreira, do Juncal em Sapucaí Mirim, da Vila Maria em Piranguçu, entre outros. As espécies herbáceas predominam na paisagem, havendo nas matas ciliares espécies arbóreas como o pinho-bravo.

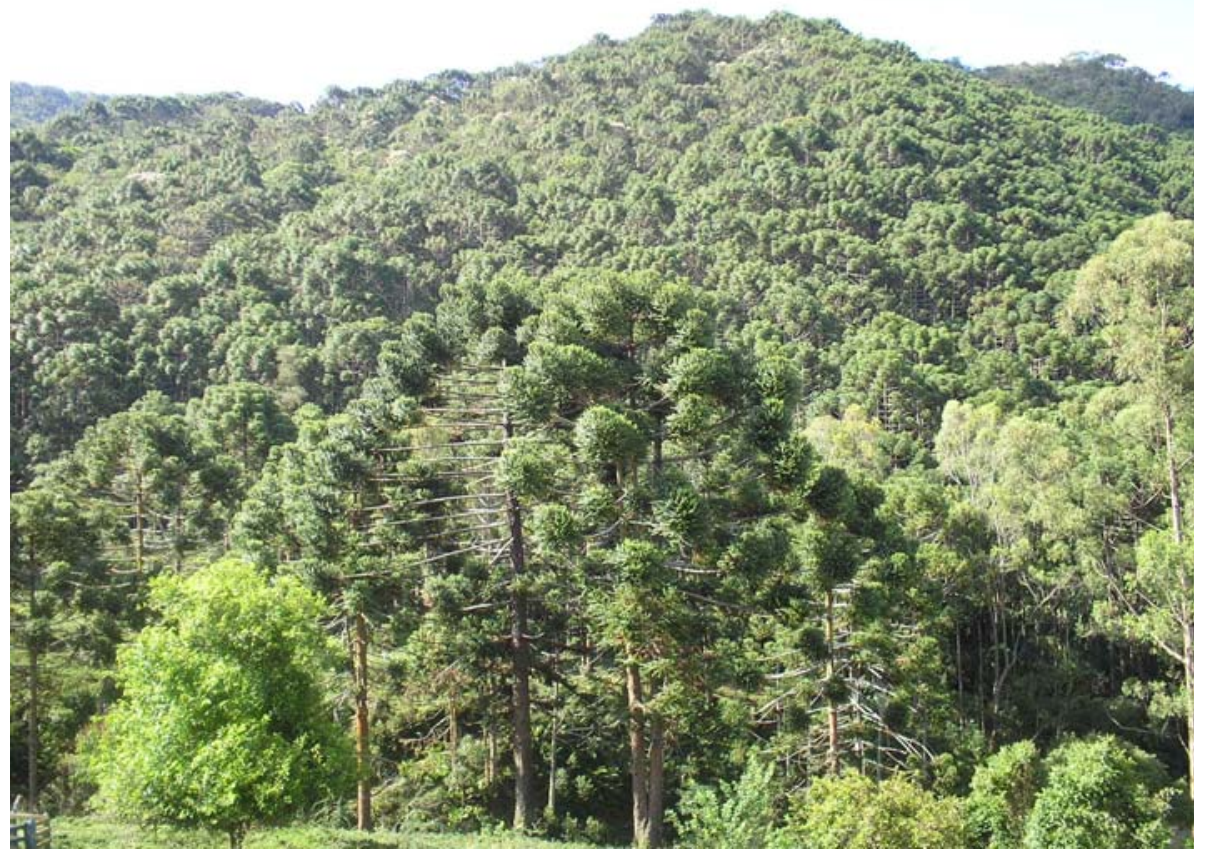

Figura 18: Mata com Araucária na APA da Serra da Mantiqueira, no município de Marmelópolis. Fonte: Helena M. Faria, 2005.

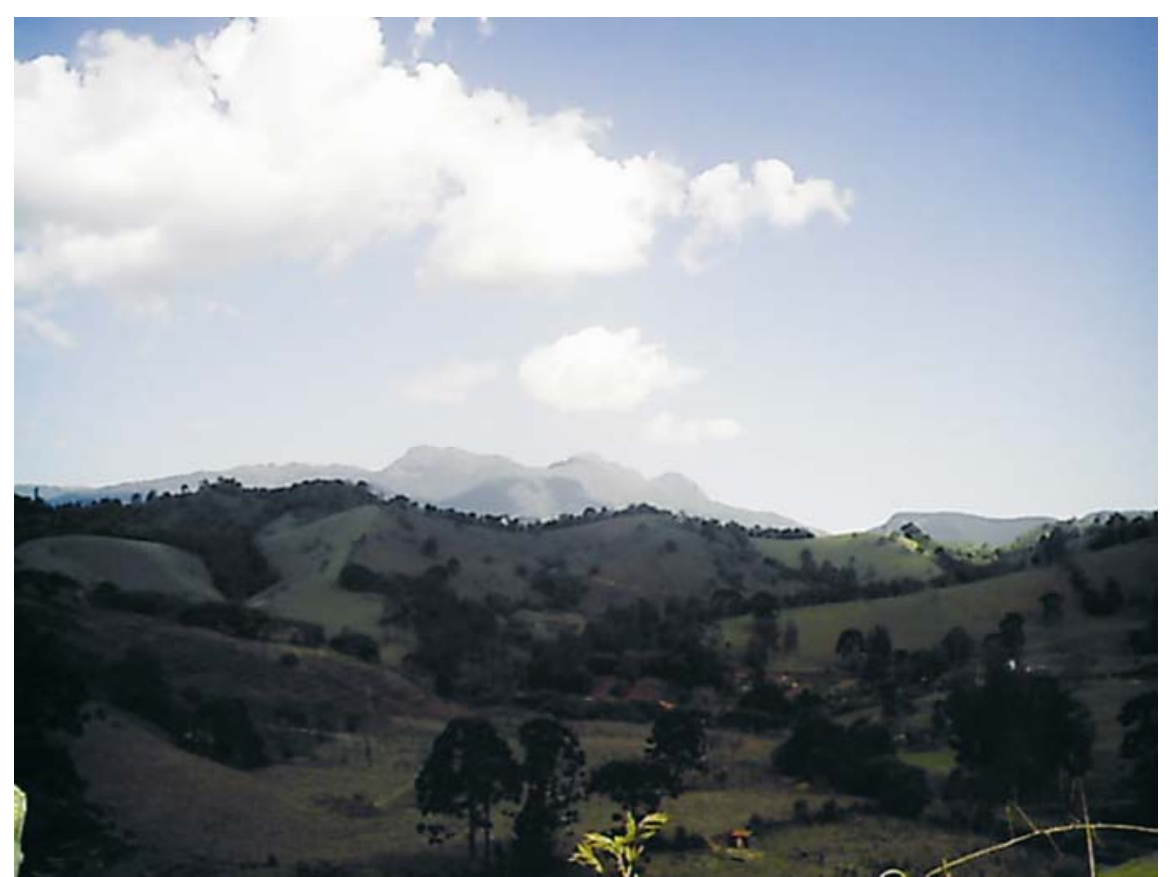

Figura 19: Vista do Pico dos Marins na APA da Serra da Mantiqueira. Foto: Henrique A. M. Faria, 2007. 


\subsection{3 - Breve História da ocupação e dos caminhos da Mantiqueira}

A história de Minas Gerais, na sua origem, é a história da procura por ouro e por diamantes. Desde o primeiro século após o descobrimento do Brasil, várias estradas foram feitas o que permitia as incursões que tinham como objetivo a busca do ouro, mas, que, acabavam por acarretar não a ocupação, mas o despovoamento da região, uma vez que nestas incursões muitos indígenas eram capturados e levados como escravos para fazendas em São Paulo ou no nordeste brasileiro, e os exploradores partiam em busca de mais minérios preciosos (RODRIGUES, 2003).

A ocupação do território mineiro começou com a bandeira de Fernão Dias Paes, no último quartel do século XVII, e com "bandeira das esmeraldas", a partir de 1674, tiveram início às primeiras manifestações de povoamento por europeus, em aldeamentos que serviam com ponto de parada para os bandeirantes. Na última década dos seiscentos teve início o verdadeiro povoamento de Minas Gerais. Nos últimos anos do século XVIII, começou a corrida do ouro que atraiu populações provenientes da Bahia, do Rio de Janeiro e também de Portugal. Os caminhos mineiros se encheram de pessoas de todos os estamentos e profissões, aventureiros e sertanistas, ascendendo à cobiça geral. Surgiram da noite para o dia, povoados junto às datas de mineração, destacando-se as vilas de ouro (Mariana, Ouro-Preto, Sabará, São João Del Rey, Caeté, Pitangui, Serro Frio) (RODRIGUES, 2003).

Segundo Santos (2001) a Estrada Real foi um dos poucos caminhos autorizados pela Coroa Portuguesa às regiões de reserva de ouro e diamante na capitania de Minas Gerais. Nestes caminhos circulavam pessoas, mercadorias, pedras preciosas e demais iguarias, sendo proibido a abertura de novos caminhos. A base da política metropolitana para essas regiões mineradoras da colônia era o 
interesse fiscal. As rotas de comunicação com as minas eram amplamente controladas e fiscalizadas para a obtenção de maior riqueza à coroa. A Estrada Real era propriedade da Coroa Metropolitana e foi o centro das atenções enquanto os ciclos do ouro e do diamante estavam no auge. Com o esgotamento das minas nos séculos XVIII e XIX, os caminhos reais tornaram-se livres de fiscalização e serviram para comunicação entre as regiões do centro-sul do território colonial. A expansão originária dos primeiros grandes caminhos do centro-sul do território colonial conformou um dos mais significativos movimentos de apropriação do interior brasileiro e de sua integração com a faixa litorânea.

A Estrada Real abrangia em muitos pontos a região da Serra da Mantiqueira, sendo que muitos de seus municípios apresentam hoje vestígios destes caminhos. 


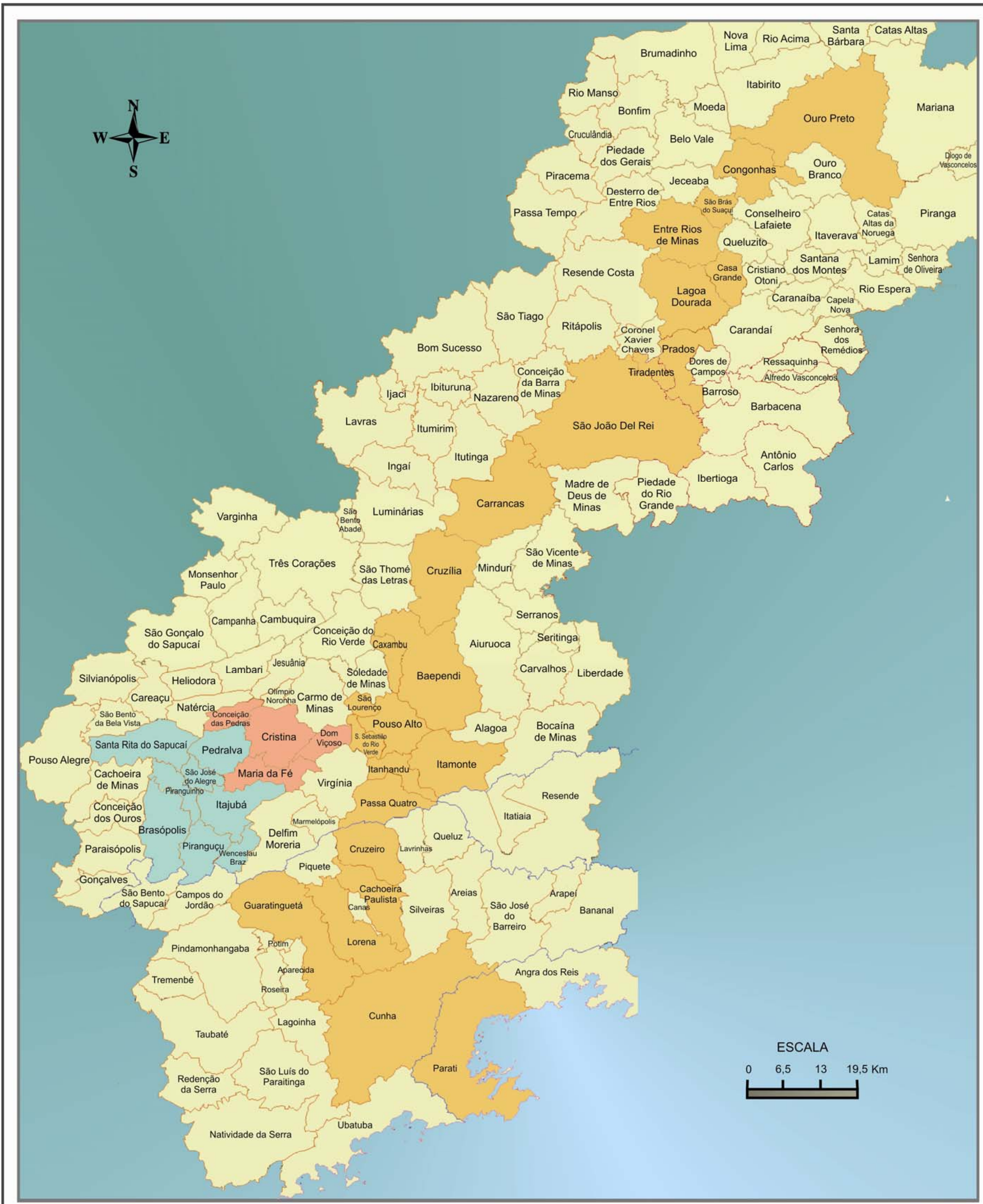

\section{Legenda}

Divisa de estado
Municípios da Estrada Real (caminho velho)
Municípios do Circuito Turístico "Caminhos do Sul de Minas"

Municípios do Circuito Turístico "Caminhos do Sul de Minas" e Estrada Real Outros municípios
Divisão Territorial dos Municípios da Estrada Real e do Circuito Turístico Caminhos do Sul de Minas

Elaboração: PEREIRA, Elaine C; FARIA, Helena M.; PAES, Fernanda S. Fonte: http://mapas.ibge.gov.br/divisão 


\subsubsection{1 — Mantiqueira: dos Sertões proibidos à industrialização}

O termo Mantiqueira é de origem Tupi-Guarani, cujo provável significado é "local onde originam-se as águas". Foi habitada desde tempos imemoriais pelos indígenas, que deixaram resíduos arqueológicos em diversas partes da região. Os primeiros bandeirantes chegaram no século $\mathrm{XVI}$, descendo pelo Rio Paraíba e passando pelo registro do Picú, atual cidade de Itamonte-MG, que os primeiros bandeirantes atravessavam a cordilheira, iniciando, a exploração e descobrimento dos demais lugares do Sul de Minas Gerais. (COSTA, 2003).

A busca pelo ouro gerou a crescente ocupação da região, mas em Minas Gerais não existia somente um único sertão, mas vários. O Sertão da Mantiqueira representava área perigosa onde os grupos indígenas (Coroados, Puris e Caparapós), a região densa e acidentada de mata atlântica, e a presença de salteadores, se constituíam em obstáculos até mesmo para aqueles que desejassem apenas passar por seus caminhos. A região da Mantiqueira também era um ponto nevrálgico na Capitania por estar na fronteira. Sendo assim seus caminhos foram proibidos, durante o século XVIII, e sua ocupação foi feita à revelia da Lei de maneira fortuita por posseiros e sertanistas (RODRIGUES, 2003).

Ao lado de todo processo de ocupação ligado à busca pelo ouro e outros minerais ocorreu uma ocupação que trouxe escravos africanos que se juntaram a índios aprisionados (a maioria proveniente de São Paulo, pois os índios Puris, Coroados e Caparapós não eram facilmente capturados) e mamelucos paulistas. As matas de campos altos nativos serviram para a criação de gado e burros de carga, dando início a uma longa tradição de gado de leite. A posterior decadência da mineração fez com que muita gente voltasse para São Paulo ou Rio de Janeiro, mas 
alguns se acomodaram em busca de subsistência na montanha, onde as terras eram mais férteis que os cerrados das Gerais (COSTA, 2003).

O isolamento da serra, representando obstáculo mais pela mata do que pela montanha, fez com que algumas de suas regiões ficassem isoladas e preservadas por quase 200 anos após as primeiras bandeiras na região, enquanto as regiões como as de Vila Rica e São João Del Rey resplandeciam em cultura. No século XVIII a colonização se fazia lenta na região devido à resistência que a floresta secular representava (COSTA, 2003).

Na região do Itatiaia começa-se o plantio de Café em 1975, especialmente na cidade de Rezende, e a expansão desta cultura gerou fortunas principalmente na região fluminense, entretanto a porção mineira não se beneficiou tanto deste ciclo.

Teodoro Sampaio, ilustre baiano radicado na Capital Paulista, engenheiro civil, que, empreendeu uma série de pesquisas de índole histórica e geográfica, além de estudos sobre navegabilidade de rios e também aérea, em vária regiões brasileiras, empreendeu duas viagens à Serra da Mantiqueira: a primeira em 1893 e a segunda em 1898. Escreveu suas impressões sobre estas viagens apresentando descrições e observações de perspectivas para seu futuro.

A primeira viagem, em 1983, foi feita saindo de trem até a cidade de LorenaSP, e a partir daí por troles até a Fazenda do Campo, de onde partiu a caravana em animais de montaria, com destino à Piquete-SP, continuando serra acima, até São Francisco dos Campos, já em território mineiro. A viagem foi promovida pelo Barão de Bocaina, em cerca de oito dias perfazendo 150 km, em várias direções e galgando altitudes superiores a 2.000 metros, e abrangeu os seguintes locais: Lorena-SP; Piquete-SP; São Francisco dos Buriquis; as Fazendas da Boa Vista, Retiro do Cerco, Córrego da Rapadura, Moreiras, Retiro do Cocho, no Ribeirão do 
Onça, já em Minas Gerais; Vila Jaguaribe (atual Campos do Jordão) e Itajubá-MG (SAMPAIO, 1978).

$\mathrm{Na}$ segunda viagem, em 1898, percorreu novamente a Vila Jaguaribe (Campos do Jordão-SP); Itajubá, Piranguçú em Minas Gerais e São Bento do Sapucaí no estado de São Paulo.

As impressões de Teodoro Sampaio sobre a região revelam uma verdadeira exaltação dos solos, das águas, da vegetação encontrada no percurso. Narra as características das fazendas de gado e o cultivo de frutas européias; a agricultura de diversas espécies que se desenvolveu principalmente em Itajubá, com as facilidades apresentadas pelas características do vale do Sapucaí. Para o futuro da região defendia a construção de um caminho de trem entre São Paulo e Minas, que poderia utilizar a via férrea mineira até então existente em Itajubá e ligá-la a Lorena. Propunha a criação de uma estação de veraneio na região de São Francisco e na Vila de Jaguaribe. Questionando a sugestão em vigor na época da transferência da capital da república para Goiás, defendeu a transferência da mesma para a região da Mantiqueira percorrida em sua viagem, alegando as qualidades do clima e a proximidades com o eixo de desenvolvimento Rio de Janeiro e São Paulo.

A região da Serra da Mantiqueira passou assim de um início marcado pelas bandeiras e pelos caminhos do ouro, com algumas de suas rotas proibidas, um curto período agrário, com a expansão da cultura cafeeira (que ocorre apenas na região fluminense da Bacia do Paraíba do Sul), chegando ao século XX como participante do processo de industrialização nacional. A ocupação durante a industrialização era maior na parte paulista da Serra da Mantiqueira (42 habitantes/ $/ \mathrm{km}^{2}$ ) e na fluminense $\left(40 \mathrm{hab} / \mathrm{km}^{2}\right)$ do que na região da serra pertencente à Minas Gerais (13 hab/km²) (COSTA, 2003). 


\subsection{4 - A APA da Serra da Mantiqueira}

A APA (Área de Proteção Ambiental) da Serra da Mantiqueira foi criada pelo decreto $\mathrm{n}^{\circ}$ 91.304, de 03 de junho de 1985, com áreas nos Estados de Minas Gerais, Rio de Janeiro e São Paulo e abrange os seguintes municípios: Aiuruoca, Alagoa, Baependi, Bocaiana de Minas, Delfim Moreira, Itanhandu, Itamonte, Liberdade, Marmelópolis, Passa Quatro, Passa Vinte, Piranguçu, Pouso Alto, Santa Rita do Jacutinga, Virgínia e Wenceslau Brás, no Estado de Minas Gerais; Campos do Jordão, Cruzeiro, Lavrinha, Pindamonhangaba, Piquete, Santo Antonio do Pinhal e Queluz, no Estado de São Paulo e Resende no Estado do Rio de Janeiro.

Possui $4.228,73 \mathrm{~km}^{2}$ ou 422.873 hectares. Região montanhosa com altitudes entre $800 \mathrm{~m}$ e $2.800 \mathrm{~m}$. No interior e entorno da APA estão presentes outras Unidades de Conservação: Parque Nacional do Itatiaia, Parque Estadual de Campos do Jordão, Parque Estadual da Serra do Papagaio, FLONA (Floresta Nacional) de Passa Quatro, e algumas RPPNs (Reservas Particulares do Patrimônio Nacional. (IBAMA/FNMA, 2003).

Segundo IBAMA/FNMA (2003) a APA da Serra da Mantiqueira apresenta as seguintes potencialidades:

- econômica: turismo, artesanato, exploração florestal sustentável, pluricultura, agropecuária;

- científica: pesquisas em ecologia, geologia, biologia, meteorologia;

- social: potencial paisagístico, cultural e estâncias hidro-climáticas;

- ambiental: qualidade hídrica, biodiversidade, remanescentes florestais, zona núcleo da Reserva da Biosfera da Mata Atlântica.

Os constrangimentos na gestão da APA incluem:

- Conflitos fundiários; 
- Ocupação desordenada e mau uso do solo;

- Poluição dos recursos hídricos;

- Grande extensão territorial;

- Lacuna de informação e envolvimento da população local com a gestão da APA.

Outras dificuldades são: os cortes de árvores na região e o número reduzido de funcionários (apenas 01 funcionário do IBAMA).

A APA da Serra da Mantiqueira tem como objetivos principais: garantir a conservação do conjunto paisagístico e da cultura regional, proteger e preservar parte de uma das maiores cadeias montanhosas do sudeste brasileiro; a flora endêmica e andina; os remanescentes dos bosques de araucárias; a continuidade da cobertura vegetal do espigão central e das manchas de vegetação primitiva e a vida selvagem, principalmente as espécies ameaçadas de extinção. Sua sede fica no município mineiro de Itamonte.

A APA (Área de Proteção Ambiental) da Serra da Mantiqueira é uma Unidade de conservação que permite a existência de áreas públicas e privadas e sua gestão é feita pelo IBAMA (Instituto Brasileiro de Meio Ambiente). São permitidas áreas urbanas e atividades industriais e agrícolas, desde que pouco poluidoras, incapazes de afetar a biota, os solos e os mananciais de água. Outras atividades são proibidas, tais como: terraplanagem, uso de biocidas em desacordo com a legislação, ou outras que possam afetar os solos, a biota e a água de seus mananciais.

O Programa Gestão Participativa na APA da Serra da Mantiqueira através do Projeto "Fortalecimento da Gestão Participativa na APA da Serra da Mantiqueira" (IBAMA/FNMA, 2003) previu que juntamente com o IBAMA fosse formado um conselho que inclui membros de diversas entidades representativas da região e que 
pudesse direcionar as ações e a gestão da APA. Este conselho já está consolidado e tomou posse no dia 07 de maio de 2004 , e possui 34 membros efetivos e 34 suplentes de diversas entidades de atividades diversificadas, mas que são provenientes da região central da APA. Uma das suas premissas é o estabelecimento de parcerias com agentes públicos e privados no cumprimento dos objetivos da APA. 
UNIDADES DE CONSERVAÇÃO FEDERAIS DO BRASIL

- Carta Imagem TM Landsat-
Área de Proteção Ambiental da Serra da Mantiqueira

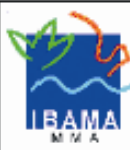

MMA - MINISTERO DO MEO AMBIENTE

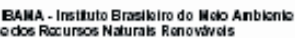

Drestera do Exs stamas

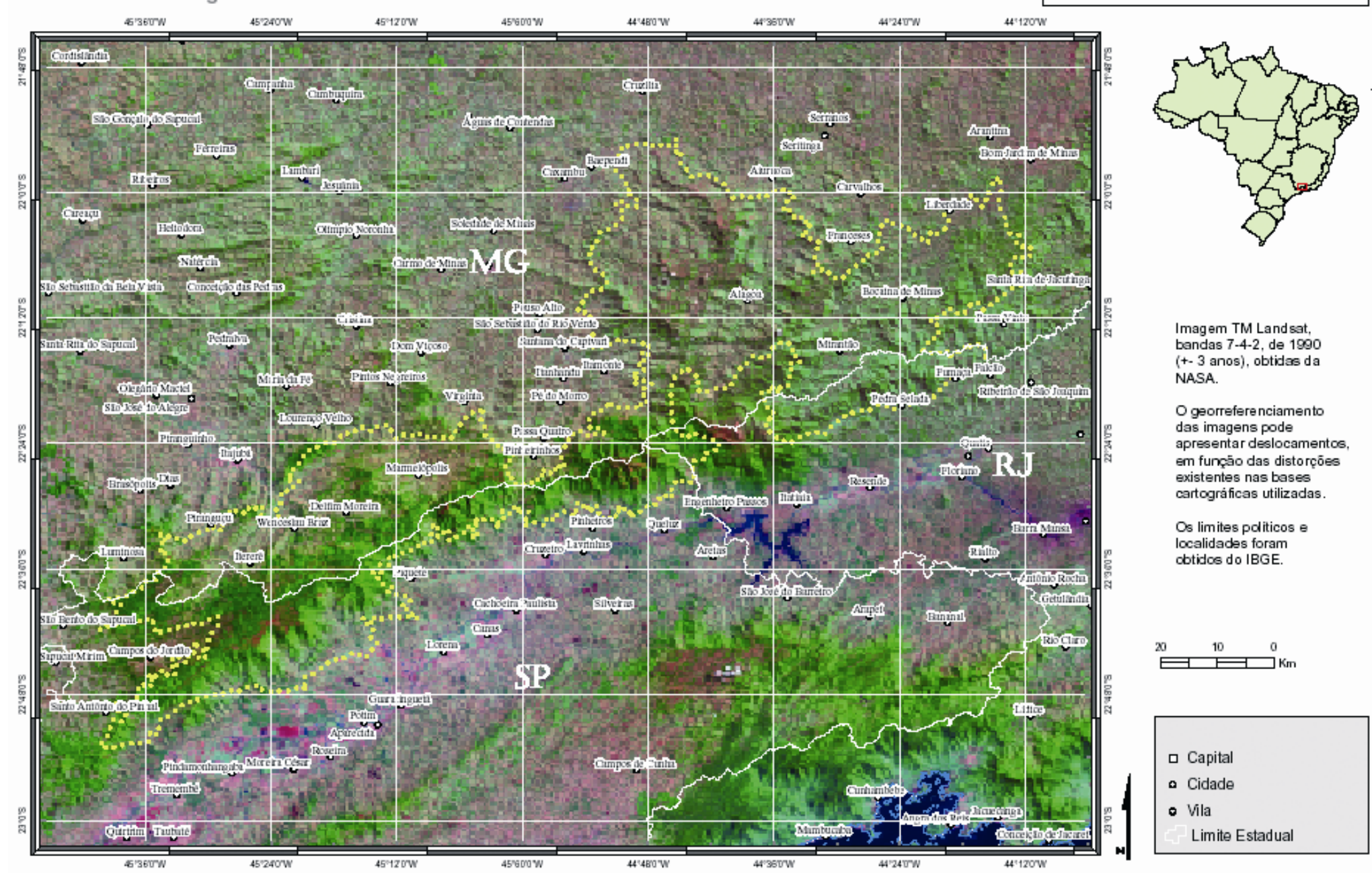

Figura 21: Localização da APA da Serra da Mantiqueira. Fonte: IBAMA. 


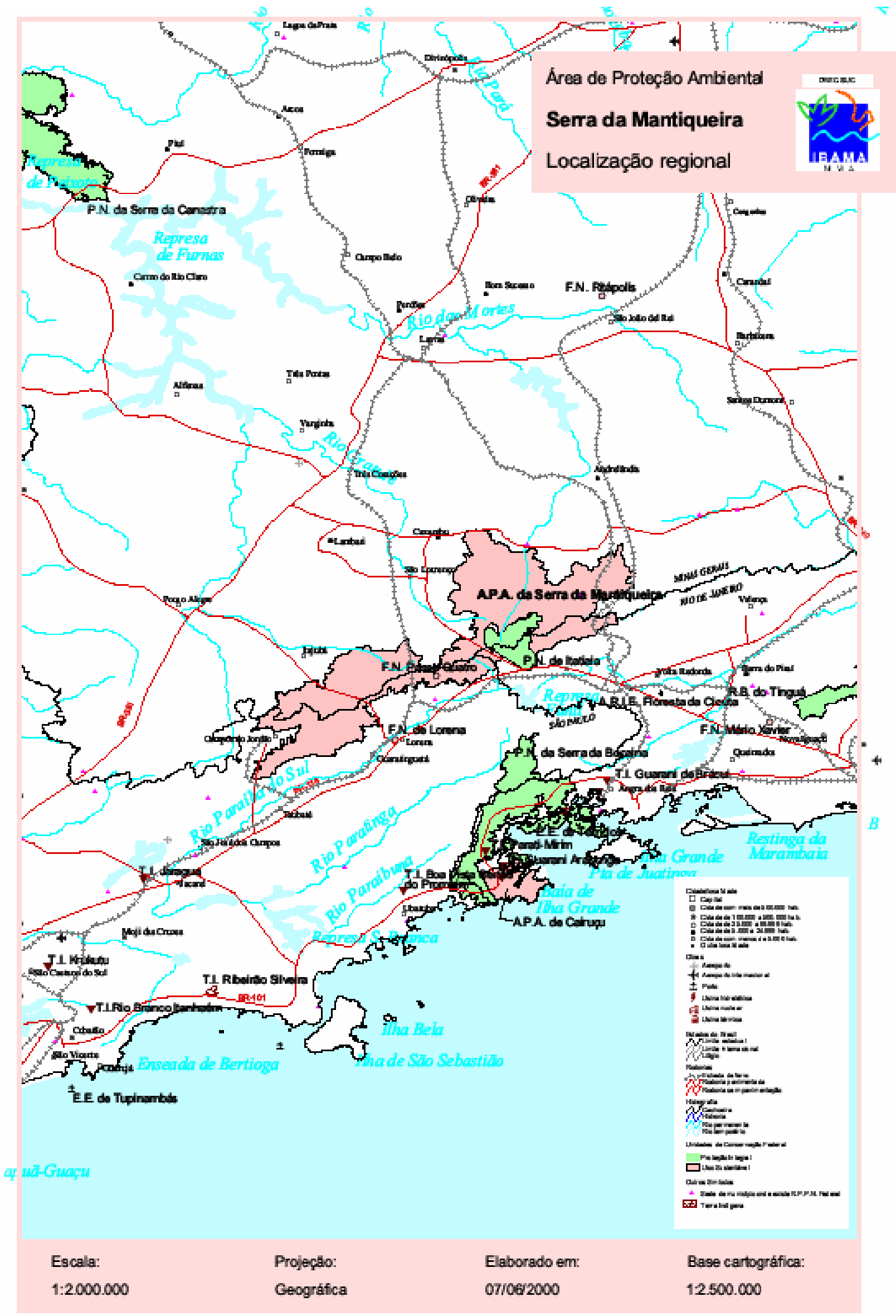

Figura 22: Mapa dos Municípios da APA da Serra da Mantiqueira. Fonte: IBAMA 


\section{3 - Breve caracterização Social e Econômica da Região do Alto e Médio Sapucaí}

\subsection{1 - O Alto Sapucaí e a APA da Serra da Mantiqueira}

Os municípios que fazem parte da APA da Serra da Mantiqueira e que pertencem concomitantemente à Bacia Hidrográfica do Sapucaí são: Delfim Moreira, Marmelópolis, Piranguçu, Virgínia, Wenceslau Brás, em Minas Gerais, e Campos de Jordão e Santo Antônio do Pinhal em São Paulo.

No comitê de Bacia Hidrográfica do Rio Sapucaí são contempladas apenas os municípios mineiros, pois os outros municípios (paulistas) se organizaram em outro comitê. As analises sobre a economia e caracterização social aqui apresentadas terão maior ênfase para os municípios mineiros que pertencem a APA da Serra da Mantiqueira e que também fazem parte da região estudada, ou seja, a Bacia Hidrográfica do Rio Sapucaí. Na intersecção entre o Alto Sapucaí, a APA da Serra da Mantiqueira e os municípios mineiros destacam-se assim os seguintes municípios: Delfim Moreira, Marmelópolis, Piranguçu, Virginia, Wenceslau Brás. A principal fonte utilizada são as informações constantes no Relatório Parcial: dados Secundários da APA da Serra da Mantiqueira Sócio-economia e Ambiente que faz parte das ações do programa Fortalecimento da Gestão Participativa da APA da Serra da Mantiqueira elaborado pelo IBAMA/FNMA, em 2003. 


\begin{tabular}{|l|c|c|c|c|c|c|c|c|c|}
\hline \multirow{2}{*}{ Municípios } & \multicolumn{3}{|c|}{1991} & \multicolumn{3}{c|}{2000} & \multicolumn{3}{c|}{2002} \\
\cline { 2 - 10 } & Urbana & Rural & Total & Urbana & Rural & Total & Urbana & Rural & Total \\
\hline $\begin{array}{l}\text { Delfim Moreira- } \\
\text { MG }\end{array}$ & 2.376 & 5.484 & 7.860 & 2.672 & 5.360 & 8.032 & & & 8.068 \\
\hline $\begin{array}{l}\text { Marmelópolis- } \\
\text { MG }\end{array}$ & 1.237 & 1.707 & 2.944 & 1.461 & 1.832 & 3.293 & & & 3.366 \\
\hline Piranguçu-MG & 1.365 & 3.216 & 4.581 & 1.692 & 3.282 & 4.974 & & & 5.075 \\
\hline Virgínia-MG & 2.482 & 6.058 & 8.540 & 3.370 & 5.328 & 8.698 & & & 8.732 \\
\hline $\begin{array}{l}\text { Wenceslau } \\
\text { Brás-MG }\end{array}$ & 1.046 & 1.441 & 2.487 & 1.188 & 1.414 & 2.602 & & & 2.619 \\
\hline $\begin{array}{l}\text { Campos de } \\
\text { Jordão-SP }\end{array}$ & 36727 & 408 & 37135 & 43.795 & 443 & 44.238 & & & \\
\hline $\begin{array}{l}\text { Santo Antônio } \\
\text { do Pinhal-SP }\end{array}$ & 2415 & 2940 & 5355 & 3.025 & 3.286 & 6.311 & & & \\
\hline
\end{tabular}

Tabela 2: População nos municípios da APA da Serra da Mantiqueira e na Bacia Hidrográfica do Alto Sapucaí. Censos do Instituto Brasileiro de Geografia e Estatística (IBGE). População urbana/rural e total (1991/2000/2002). Fonte: IBAMA/FNMA, 2003.

\begin{tabular}{|l|c|c|}
\hline \multicolumn{1}{|c|}{ Municípios } & $\mathbf{1 9 9 1}$ & $\mathbf{2 0 0 0}$ \\
\hline Delfim Moreira-MG & 69,77 & 66,73 \\
\hline Marmelópolis-MG & 57,98 & 55,63 \\
\hline Piranguçu-MG & 70,20 & 65,98 \\
\hline Virgínia-MG & 70,94 & 61,26 \\
\hline Wenceslau Brás-MG & 57,94 & 54,34 \\
\hline Campos de Jordão-SP & 1,10 & 1,00 \\
\hline Santo Antônio do Pinhal-SP & 54,90 & 52,07 \\
\hline
\end{tabular}

Tabela 3: Porcentagem de população rural (1991/2000) nos municípios da APA da Serra da Mantiqueira e da

Bacia Hidrográfica do Alto Sapucaí. Censos: Instituto Brasileiro de Geografia e Estatística (IBGE). População urbana/rural e total (1991/2000/2002). Fonte: IBAMA/FNMA, 2003. 
População rural, 2000

Municípios da Região da APA da Serra da Mantiqueira
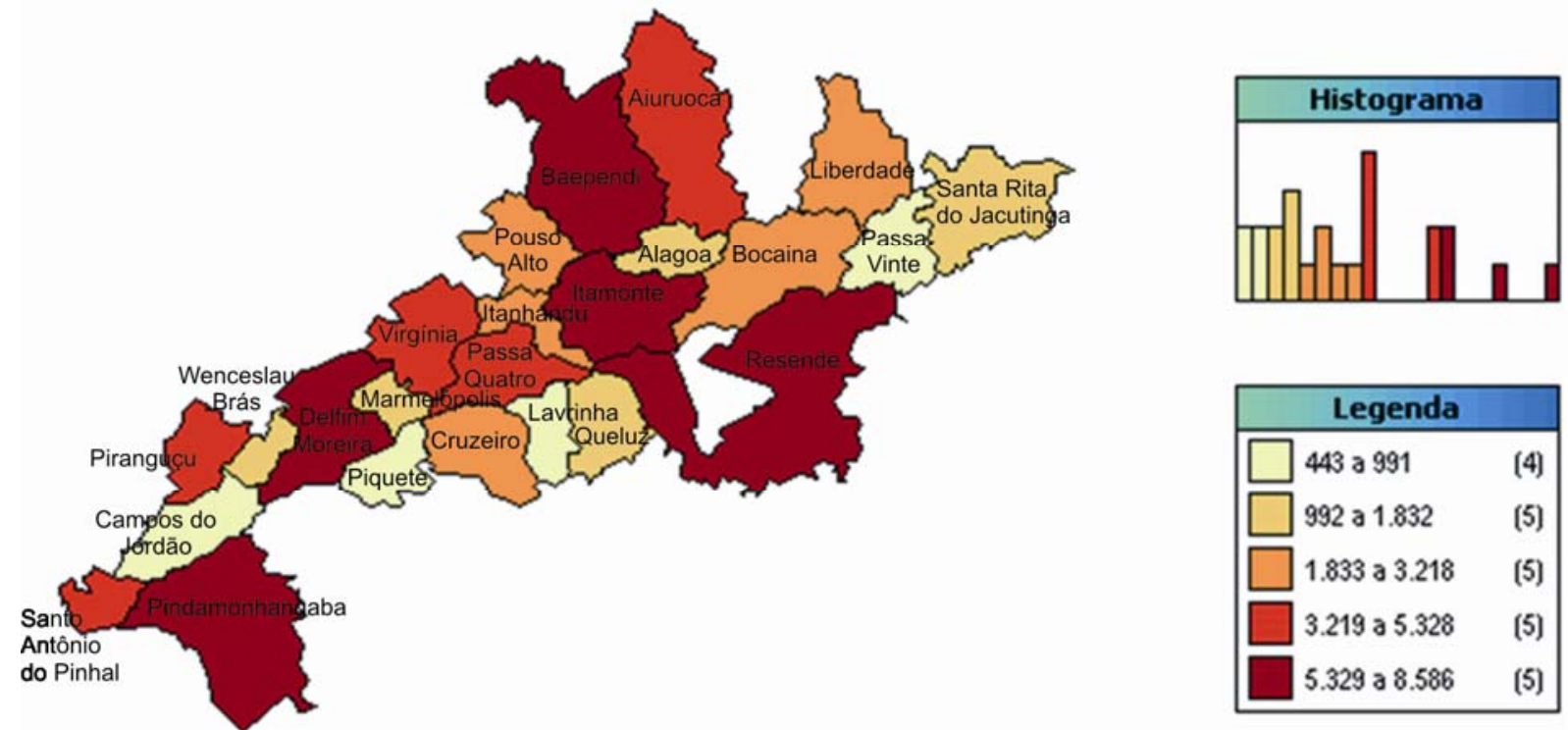

Figura 23: Porcentagem de população rural (1991/2000) nos municípios da APA da Serra da Mantiqueira e da Bacia Hidrográfica do Alto Sapucaí. Censos: Instituto Brasileiro de Geografia e Estatística (IBGE). População urbana/rural e total (1991/2000/2002). Fonte: IBAMA/FNMA, 2003.

Os municípios que fazem parte ao mesmo tempo da APA da Serra da

Mantiqueira e da Bacia Hidrográfica do Sapucaí, apresentam em sua maioria, população rural maior do que a urbana, com exceção de Campos do Jordão.

\begin{tabular}{|c|c|c|c|c|c|c|c|c|c|c|}
\hline \multirow[t]{2}{*}{ Municípios } & \multicolumn{2}{|c|}{$\begin{array}{c}\text { Agropecuária } \\
\text { Extração e } \\
\text { Pesca }\end{array}$} & \multicolumn{2}{|c|}{ Indústria } & \multicolumn{2}{|c|}{ Comércio } & \multicolumn{2}{|c|}{ Serviços } & \multicolumn{2}{|c|}{ PEA } \\
\hline & Absol & $\%$ PEA & Absol & \%PEA & Absol & $\%$ PEA & Absol & $\%$ PEA & Absol & $\begin{array}{l}\text { \%Pop } \\
\text { Total }\end{array}$ \\
\hline Delfim Moreira-MG & 1.240 & 44,27 & 400 & 14,28 & 300 & 10,71 & 861 & 30,74 & 2.801 & 34,87 \\
\hline Marmelópolis-MG & 639 & 55,81 & 153 & 13,36 & 113 & 9,87 & 240 & 20,96 & 1.145 & 34,77 \\
\hline Piranguçu-MG & 741 & 34,16 & 397 & 18,30 & 261 & 12,03 & 770 & 35,50 & 2.169 & 43,61 \\
\hline Virgínia-MG & 1.616 & 50,71 & 454 & 14,25 & 189 & 5,93 & 928 & 29,12 & 3.187 & 36,64 \\
\hline $\begin{array}{l}\text { Wenceslau Brás- } \\
\text { MG }\end{array}$ & 319 & 37,05 & 281 & 32,64 & 50 & 5,81 & 211 & 24,51 & 861 & 33,09 \\
\hline $\begin{array}{l}\text { Campos de } \\
\text { Jordão-SP }\end{array}$ & & & & & & & & & & \\
\hline $\begin{array}{l}\text { Santo Antônio do } \\
\text { Pinhal-SP }\end{array}$ & & & & & & & & & & \\
\hline
\end{tabular}

Tabela 4: População ocupada por setores econômicos (2000) nos municípios da APA da Serra da Mantiqueira e da Bacia Hidrográfica do Alto Sapucaí. Censos: Instituto Brasileiro de Geografia e Estatística (IBGE). População urbana/rural e total (1991/2000/2002). Fonte: IBAMA/FNMA, 2003.

A maior parte da população economicamente ativa tem como ocupação

principal o setor de agropecuária, extração e pesca; seguido do setor industrial e do 
setor de comércio e serviços. A porcentagem de população economicamente ativa em todos os municípios esta abaixo de $50 \%$, o que caracteriza um baixo nível de emprego fazendo com que exista uma tendência ao abandono do município, afetando o crescimento populacional.

Os produtos agropecuários mais empregados na região são: pinus, batata inglesa. Existe também a exploração de água mineral e outros minerais não metálicos. No setor industrial as principais atividades são confecções e processamento de madeira (IBMA/FNMA, 2003). O setor de turismo começa a se desenvolver com o Circuito Terras Altas da Mantiqueira.

O Índice de Desenvolvimento Humano (IDH) é um indicador de qualidade de vida que combina três componentes básicos do desenvolvimento humano: a longevidade, a educação e a renda. Foi criado no início da década de 90 para o PNUD (Programa das Nações Unidas para o Desenvolvimento) pelo conselheiro especial Mahbub ul Haq. A metodologia de cálculo do IDH envolve a transformação destas três dimensões em índices de longevidade, educação e renda, que variam entre 0 (pior) e 1 (melhor), e a combinação destes índices em um indicador síntese. Quanto mais próximo de 1 o valor deste indicador, maior será o nível de desenvolvimento humano do país ou região.

O índice de desenvolvimento humano é maior em Campos do Jordão do que em outros municípios da região objeto de estudo, o que pode indicar um privilégio dos municípios mais urbanizados. Todos os municípios apresentam índice de desenvolvimento humano acima de 0,72 em 2000, que se comparado com o IDH brasileiro que é 0,792 , representa um patamar de desenvolvimento médio. Segundo a metodologia do IDH, índices abaixo de 0,50 são considerados baixos e a região 
assim classificada fica em um patamar de desenvolvimento baixo e aqueles com índices acima de 0,80 são considerados altos.

\begin{tabular}{|c|c|c|}
\hline \multirow{2}{*}{ Municípios } & \multicolumn{2}{|c|}{ Índice de desenvolvimento humano municipal } \\
\hline & 1991 & 2000 \\
\hline Aiuruoca-MG & 0,641 & 0,736 \\
\hline Alagoa-MG & 0,642 & 0,726 \\
\hline Baependi-MG & 0,661 & 0,742 \\
\hline Bocaina de Minas-MG & 0,647 & 0,724 \\
\hline Campos do Jordão-SP & 0,741 & 0,82 \\
\hline Cruzeiro-SP & 0,755 & 0,809 \\
\hline Delfim Moreira-MG & 0,649 & 0,72 \\
\hline Itamonte-MG & 0,686 & 0,792 \\
\hline Itanhandu-MG & 0,721 & 0,795 \\
\hline Lavrinhas-SP & 0,698 & 0,768 \\
\hline Liberdade-MG & 0,635 & 0,736 \\
\hline Marmelópolis-MG & 0,629 & 0,721 \\
\hline Passa Quatro-MG & 0,683 & 0,777 \\
\hline
\end{tabular}

Tabela 5: Índice de desenvolvimento humano nos municípios da APA da Serra da Mantiqueira (1991/2000). Instituto Brasileiro de Geografia e Estatística (IBGE).

População urbana/rural e total (1991/2000/2002). Fonte: IBAMA/FNMA, 2003. 
Índice de Desenvolvimento Humano Municipal, 2000

Municípios da Região da APA da Serra da Mantiqueira
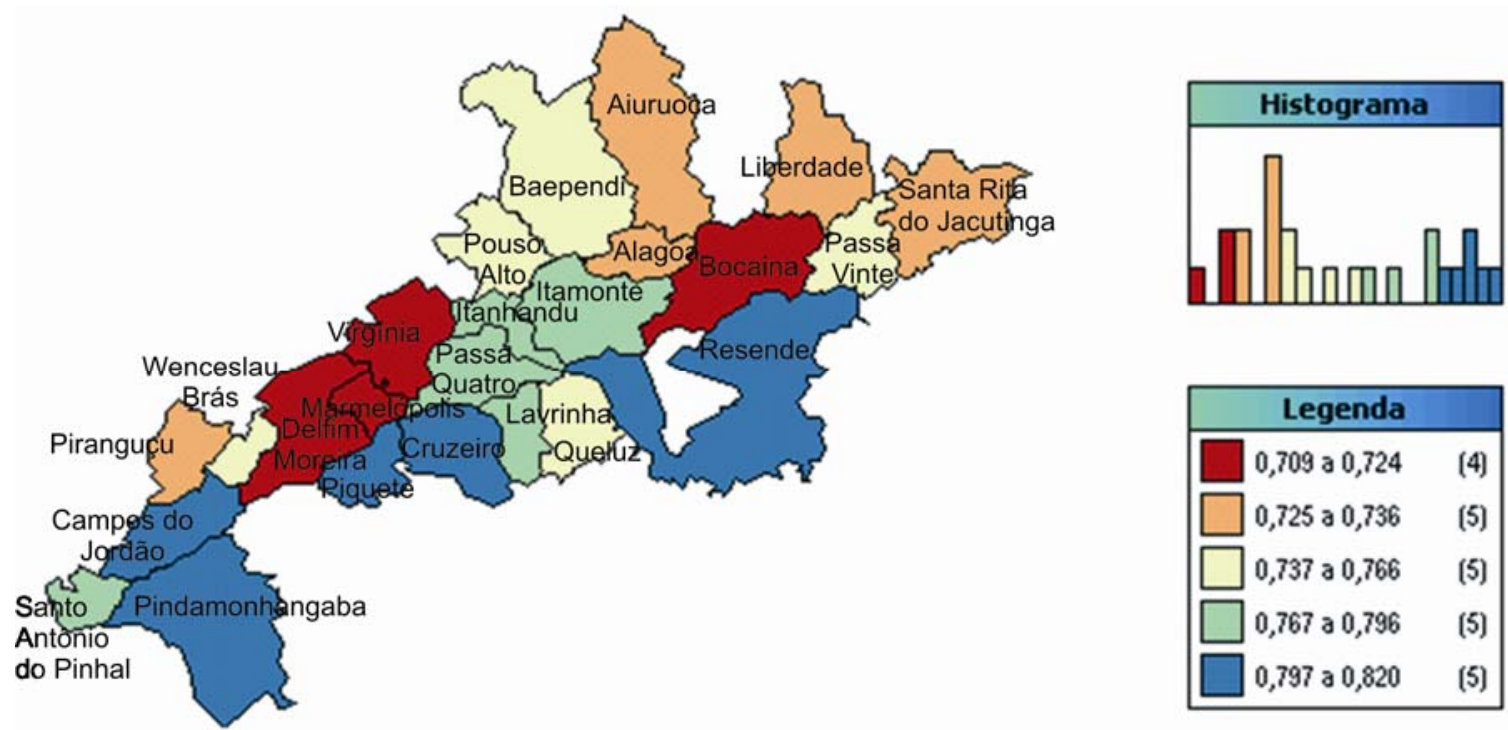

Figura 24: Índice de Desenvolvimento Humano Municipal, 2000, nos municípios da APA da Serra da Mantiqueira. Fonte: IBAMA/FNMA, 2003.

Os municípios da APA da Serra da Mantiqueira que fazem parte da Bacia Hidrográfica do Sapucaí, de maneira geral têm atividades mais rurais do que urbanas, com exceção de Campos do Jordão. Apresentam também um índice de desenvolvimento considerado médio, mas a cobertura vegetal da região é uma das menos preservadas em toda APA. 


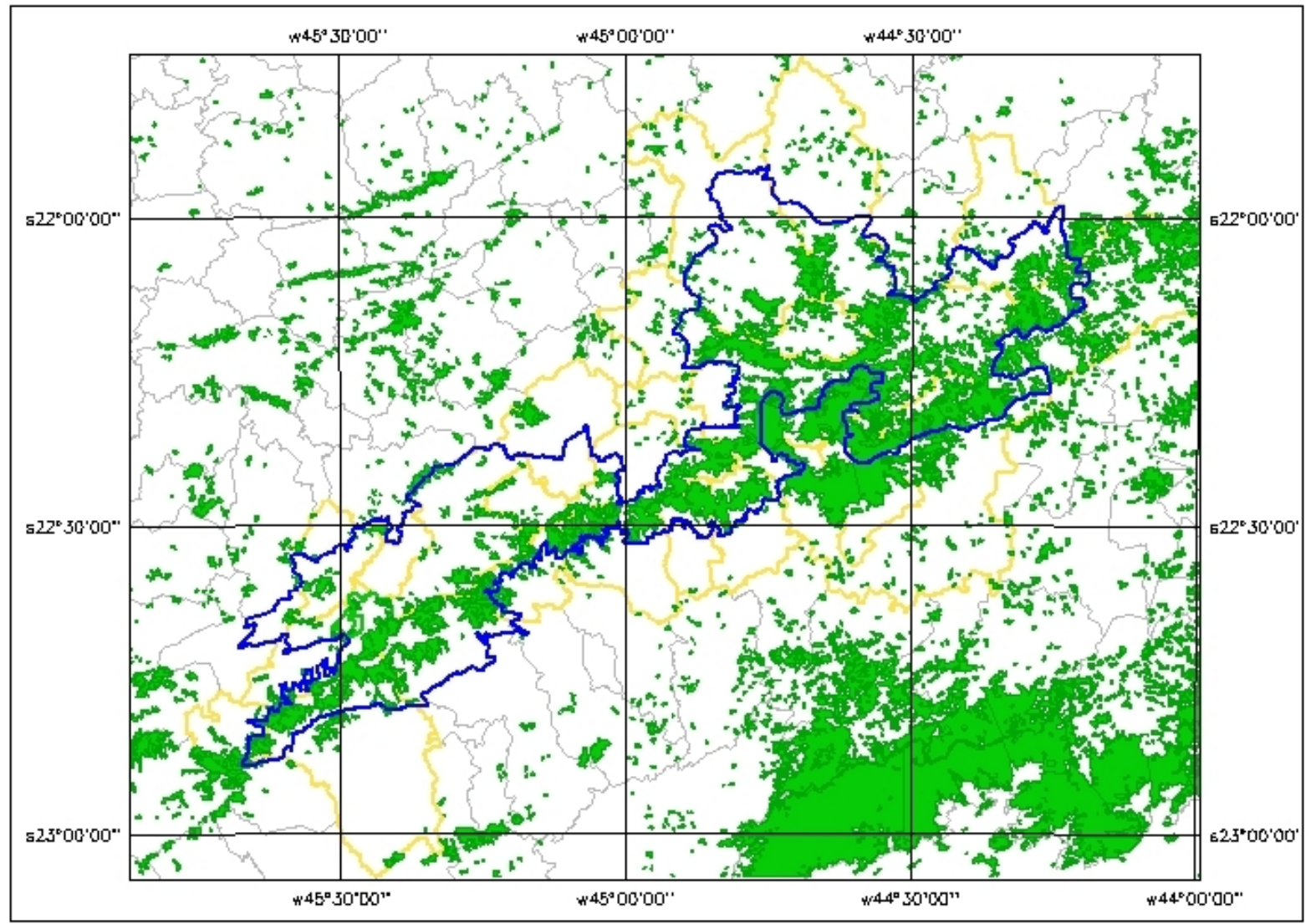

Figura 25: Remanescentes Florestais na APA Serra da Mantiqueira. Fonte: Fundação SOS Mata Atlântica.

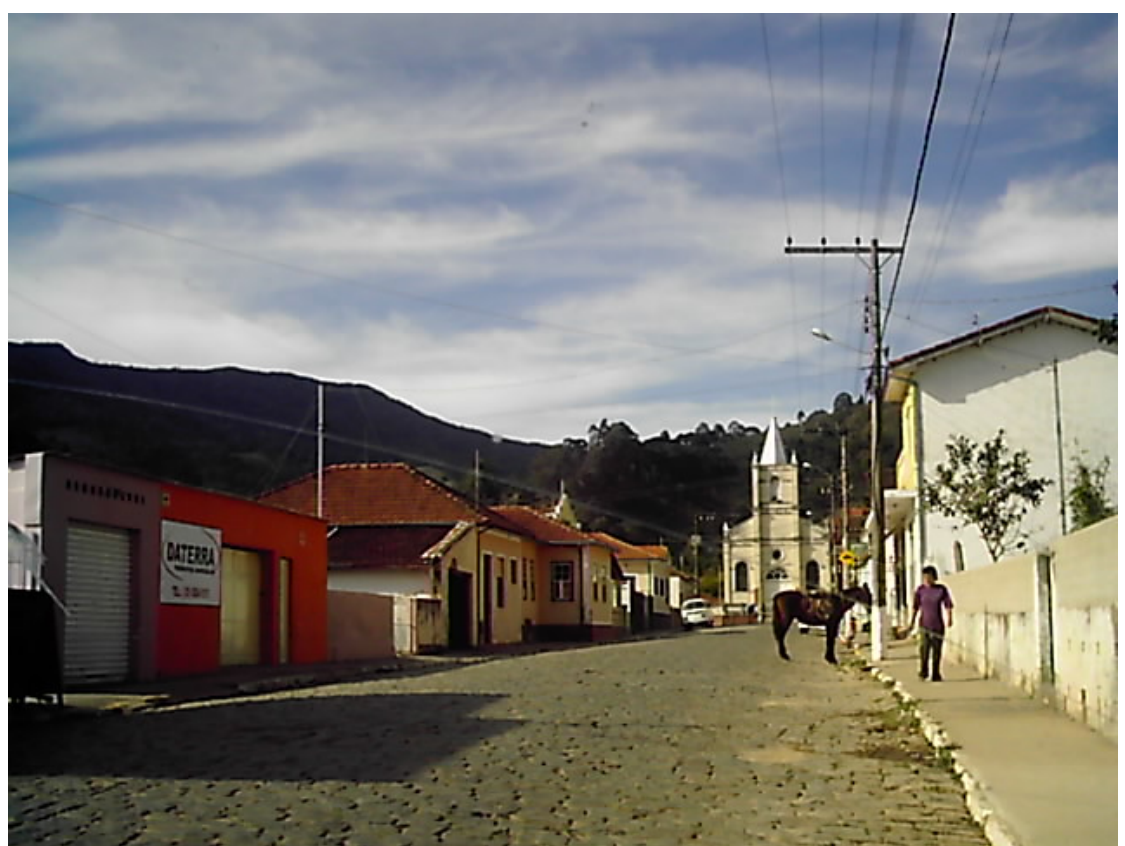

Figura 26: Cidade de Delfim Moreira na APA da Serra da Mantiqueira. Foto: Izabel M. Faria, 2007. 


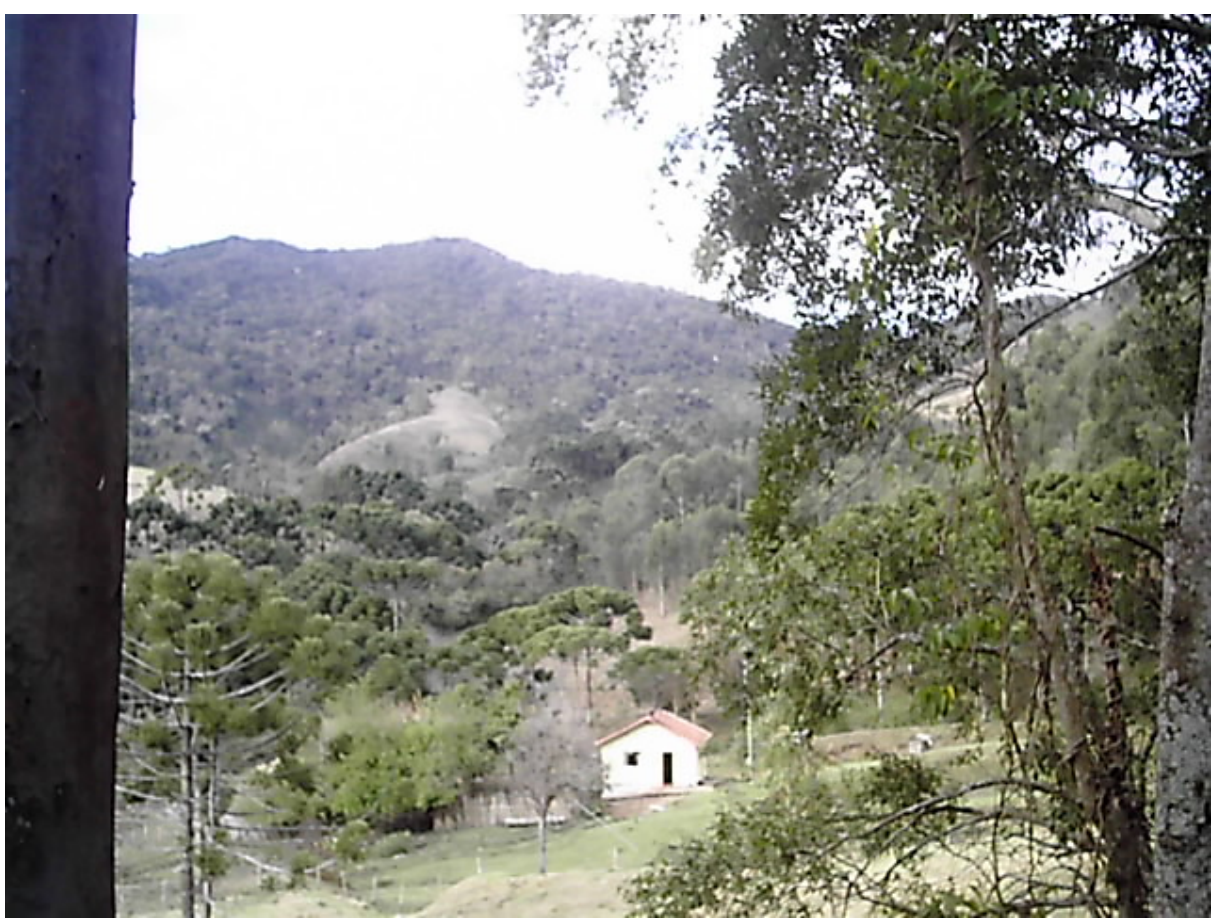

Figura 27: Propriedade Rural em Delfim Moreira.

Foto: Izabel M. Faria, 2007.

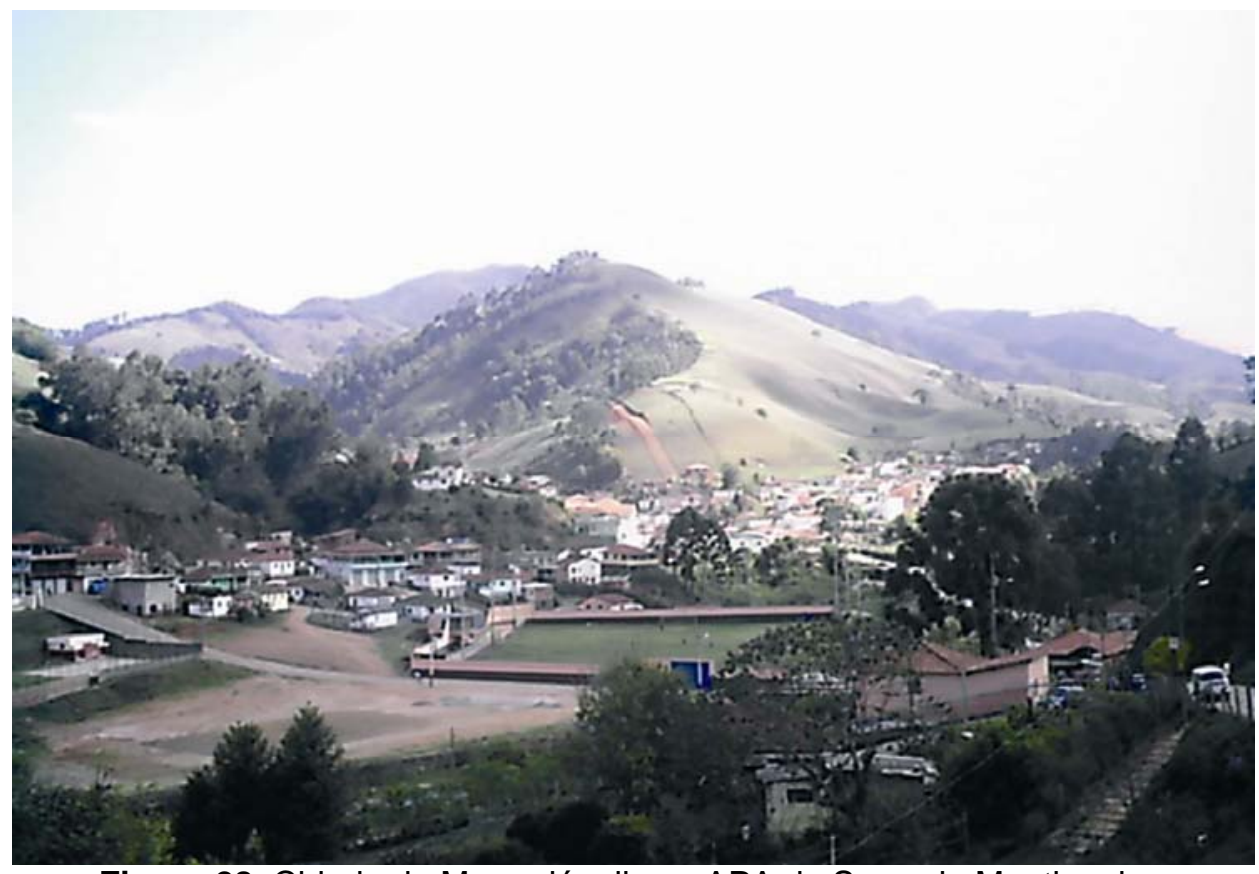

Figura 28: Cidade de Marmelópolis na APA da Serra da Mantiqueira. Foto: Henrique A. M. Faria, 2007. 


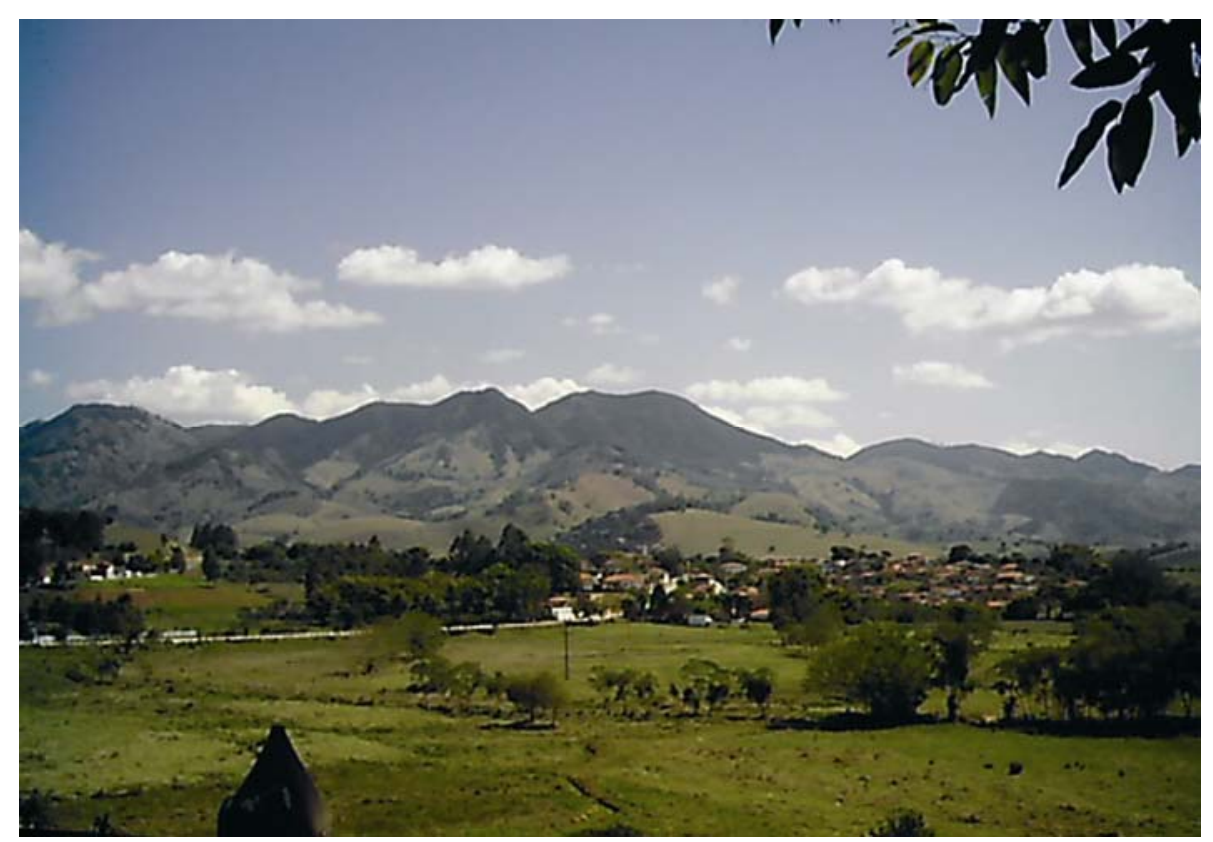

Figura 29: Cidade de Virgínia na APA da Serra da Mantiqueira. Foto: Elaine C. Pereira, 2007.

Segundo o Relatório de Dados Secundários do Programa de Fortalecimento de Gestão Participativa na APA da Serra da Mantiqueira (IBMA/FNMA, 2003) os principais problemas ambientais na região dos municípios paulistas e fluminenses da APA são: mineração de areia; falta de infra-estrutura dos municípios; destinação final de lixo doméstico inadequada; falta de moradia para as classes mais carentes, obrigando as famílias a ocuparem áreas de risco e de mananciais; especulação imobiliária; desmembramento irregular de áreas; poluição de rios; falta de fiscalização preventiva; desmatamento para pecuária; erosões e deslizamentos. Em sua maior parte coincidem com os problemas dos municípios mineiros acrescidos da dificuldade de trânsito nesta região devido à má conservação de estradas.

\subsection{2 - O Médio Sapucaí: crescimento econômico e urbano}

O vale que se forma no Médio Sapucaí é mais favorável ao desenvolvimento da agricultura, da indústria e da ocupação urbana, sendo que historicamente os 
centros urbanos localizados às margens do Sapucaí se desenvolveram mais economicamente do que os municípios situados nas cabeceiras do rio. Ecologicamente este fato é favorável, por preservar a montanha, mas por outro lado a faixa de ocupação ao longo do rio leva a uma constante luta com suas cheias. É necessário também preservar o rio.

Os municípios com maior população urbana, maior índice de industrialização ao longo da Bacia Hidrográfica do Sapucaí em sua porção média são: Pouso Alegre, Itajubá e Santa Rita do Sapucaí. Sua localização coincide com o trajeto da Rodovia Federal Juscelino Kubitschek, a BR 459, que liga a Rodovia Fernão Dias até a Presidente Dutra, no município paulista de Lorena. 


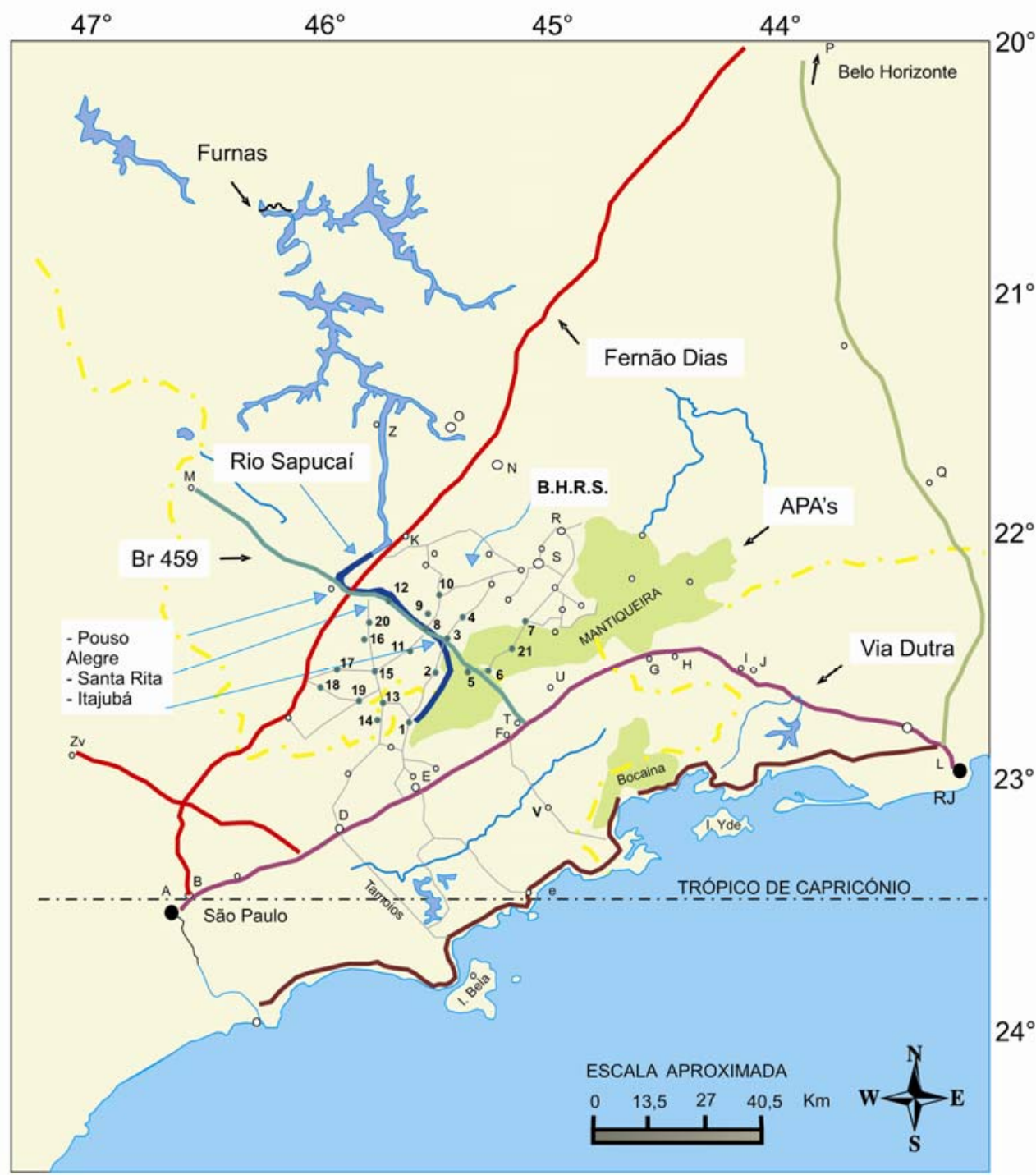

\section{MUNICÍPIOS DO ALTO E MÉDIO SAPUCAI}

1 - Campos do Jordão - SP

2 - Piranguçu

3 - Itajubá

4 - Maria da Fé

5 - Wenceslau Brás

6 - Delfim Moreira

7 - Virgínia

8 - Piranguinho

9 - São José do Alegre

10 - Pedralva

11 - Brasópolis

12 - Santa Rita do Sapucai

13 - São Bento do Sapucaí - SP

14 - Sapucai Mirim

15 - Paraisópolis

16 - Conceição dos Ouros

17 - Consolação

18 - Córrego do Bom Jesus

19 - Gonçalves

20 - Cachoeira de Minas

21 - Marmelópolis

\section{LEGENDA}

Municípios do Alto e Médio Sapucaí

Outros municípios

- $\mathrm{Br} 459$

— Via Dutra

- Br 040

_ Rodovia Rio-Santos

- Outras rodovias Limites Estaduais

Rio Sapucaí

APA's (Serra da Mantiqueira)

Elaboração: Helena M.

Fonte: Guia Quatro Rodas

\section{OUTROS MUNICÍPIOS}

D - São José dos Campos

$\mathrm{H}$ - Rezende

$\mathrm{N}$ - Três Corações

S - São Lourenço

E - Taubaté

I - Barra Mansa

O - Varginha

$\mathrm{T}$ - Lorena

F - Guaratinguetá

M - Poços de Caldas

$Q$ - Juiz de Fora

U - Cruzeiro

G - Itatiaia

R - Caxambu

V - Cunha

Mapa Esquemático do

Sudeste com Destaque para a Bacia Hidrográfica do Rio Sapucaí

Figura 30: Rede Viária na Região do Alto e Médio Sapucaí.

Fonte: Elaboração própria utilizando as fontes: IBGE e IGAM. 
Castro e Abreu (2004) afirmam que de maneira geral a área de influência do mercado consumidor do Sul de Minas Gerais esteve fortemente associada aos municípios que integram o eixo formado pelas Rodovias Fernão Dias (Pouso Alegre, Varginha e Lavras), pela Rota Tecnológica 459 (Poços de Caldas, Pouso Alegre, Santa Rita do Sapucaí e Itajubá) pelo Circuito das Águas, e em menor proporção, pelo eixo da Rodovia MG 050.

Sul de Minas é o nome oficial utilizado pela SEPLAN/MG (Secretaria de Planejamento de Minas Gerais) para uma das dez regiões de planejamento mineiras. As metrópoles Belo Horizonte, Rio de Janeiro e São Paulo são vértices do triângulo mais desenvolvido do país (ARANTES, 2001). Segundo Andrade (2003) a macrorregião de planejamento do Sul de Minas é composta por 154 municípios, totalizando 43 mil quilômetros quadrados, entre as coordenadas geográficas $20^{\circ}$ a $23^{\circ}$ de latitude Sul e $44^{\circ}$ a $47^{\circ}$ de longitude Oeste.

Macro-espaço é a terminologia utilizada pela Fundação João Pinheiro para representar os espaços do território cuja formação se estrutura em função da força de polarização exercida por cada uma destas cidades. No caso do Sul de Minas, a região do Médio Sapucaí está sob a influência direta de São Paulo, sendo necessário considerar que o macro-espaço mineiro polarizado por São Paulo é formado pelas regiões Sul, Alto Paranaíba e Triângulo Mineiro (ARANTES, 2001).

A região do Sul de Minas é bastante urbanizada, sendo que segundo dados da Fundação João Pinheiro seu grau de urbanização foi de 75,32\% em 1996. Dentre as regiões mineiras, apresenta importante taxa de crescimento populacional $1,24 \%$ ao ano, no período de 1991 até 1996, ficando atrás das regiões do Triângulo Mineiro (1,76\% ao ano), Central (1,71\% ao ano), Alto Paranaíba (1,57\% ao ano) e CentroOeste (1,57\% ao ano) (ARANTES, 2001). 
Considerando o Índice de Desenvolvimento Humano é importante observar que no ano de 1991 o IDH de Minas Gerais foi de 0,735 (nível médio), ficando em $10^{\circ}$ lugar no ranking dos estados brasileiros. Os 28 municípios mineiros com alto desenvolvimento humano são de médio e grande porte e neles moram cerca de $27 \%$ da população deste estado. Já entre os 98 de baixo desenvolvimento humano, predominam os de pequeno porte e neles não vive mais que $9 \%$ da população do estado. No grupo dos dez municípios mineiros de maior IDH aparecem dois municípios do Vale do Sapucaí, Pouso Alegre (sexto) e Itajubá (quarto lugar) (ARANTES, 2001):

1- Uberlândia IDH 0,839

2- Belo Horizonte IDH 0,838

3- Varginha IDH 0,835

4- Itajubá IDH 0,833

5- Juiz de Fora IDH 0,832

6- Pouso Alegre IDH 0,829

7- Poços de Caldas IDH 0,827

8- Uberaba IDH 0,827

9- Guaxupé IDH 0,825

10-Alfenas $\quad$ IDH 0,819

A abordagem tradicionalmente adotada em planejamento regional, de pólos de desenvolvimento, que defendia a concentração de investimentos em determinados locais, está mudando para a de eixos estratégicos de transporte ou eixos de desenvolvimento. Isto faz com que o papel das rodovias na economia mineira seja extremamente significativo, sendo que cerca de $65 \%$ de seu PIB é produzido na área de influencia da Rodovia Fernão Dias. A BR 459 contribui para a 
forte polarização de suas cidades-sede sobre outros municípios situados ao longo de seus aproximadamente $250 \mathrm{~km}$. (ARANTES, 2001).

Uma proposta recente de desenvolvimento econômico regional aparece por iniciativa da comunidade local: a Rota Tecnológica 459. Este projeto propõe um processo de desenvolvimento integrado para os municípios abrangidos pela Rodovia BR 459, que liga a Rodovia Fernão Dias à Rodovia Presidente Dutra, e procura direcionar as ações dos municípios (governo e sociedade organizada) para o aproveitamento de seu potencial educacional de alta qualidade, buscando investimentos em ciência e tecnologia para atrair empreendimentos de base tecnológica, preservando as características naturais e culturais da região. (www.itajubá.mg.gov.br).

As cidades do Vale do Sapucaí apresentam altos índices em educação sendo que Itajubá possui uma Universidade Federal (UNIFEI), que impulsiona o desenvolvimento na área tecnológica e Santa Rita do Sapucaí também tem ensino voltado para área tecnológica e desenvolve projetos de empreendedorismo premiados.

\subsubsection{1 - Crescimento Urbano e Qualidade de Vida no vale do Sapucaí}

Andrade (2003) avaliou a qualidade de vida em municípios do Sul de Minas Gerais utilizando-se de dados de censos demográficos, indicadores do IDH (Índice de Desenvolvimento Humano) e a análise da paisagem, uma vez que o IDH não mensura modificações espaciais. Os municípios avaliados foram Poços de Caldas, Varginha, Pouso Alegre, Passos, Itajubá e Lavras por formarem a estrutura principal da macro-região de planejamento do Sul de Minas, em virtude de serem os mais populosos e possuírem maior rede de infra-estrutura sócio-econômica. Estes 
municípios apresentaram expressivo crescimento demográfico a partir da década de 1970 e no período de 1970 até 2000, a população urbana apresentou ritmo de crescimento maior do que a população total nestes municípios, como ilustram as tabelas 6 e 7.

\begin{tabular}{lcccc}
\multicolumn{1}{c}{ Municípios } & $\mathbf{1 9 7 0}$ & $\mathbf{1 9 8 0}$ & $\mathbf{1 9 9 1}$ & $\mathbf{2 0 0 0}$ \\
Poços de Caldas & 52.452 & 81.399 & 104.957 & 130.764 \\
Varginha & 36.565 & 57.657 & 82.169 & 104.165 \\
Pouso Alegre & 26.208 & 50.758 & 74.267 & 97.756 \\
Passos & 39.603 & 56.973 & 73.925 & 89.911 \\
Itajubá & 42.825 & 53.441 & 68.726 & 76.983 \\
Lavras & 35.823 & 45.119 & 60.482 & 74.296
\end{tabular}

Tabela 6: Crescimento da População Urbana em Municípios do Sul de Minas no período de 1970 até 2000. Estatísticas dos censos demográficos do Instituto Brasileiro de Geografia e Estatística (IBGE). Fonte: Andrade (2003)

\begin{tabular}{lcccc}
\multicolumn{1}{c}{ Municípios } & 1970 & 1980 & 1991 & 2000 \\
Poços de Caldas & 100 & 155 & 200 & 249 \\
Varginha & 100 & 157 & 224 & 285 \\
Pouso Alegre & 100 & 193 & 283 & 373 \\
Passos & 100 & 144 & 187 & 227 \\
Itajubá & 100 & 125 & 160 & 180 \\
Lavras & 100 & 128 & 169 & 207
\end{tabular}

Tabela 7: Comparação do rítmo de crescimento da população urbana entre municípios do Sul de Minas. 1970 = 100. Estatísticas dos censos demográficos do Instituto Brasileiro de Geografia e Estatística (IBGE). Fonte: Andrade (2003).

Na pesquisa realizada por Andrade (2003) Pouso Alegre e Itajubá apresentam ritmo de crescimento diferentes, apesar da pequena distância entre as duas cidades, que é de $60 \mathrm{~km}$. Isso se deve ao fato de que Pouso Alegre polariza municípios mais populosos e com economia mais dinâmica dentro da macro-região do Sul de Minas, tais como: Santa Rita do Sapucaí, Extrema, Monte Sião, Jacutinga e Cambuí, 
enquanto Itajubá possui em sua área de influência municípios menos populosos e com uma economia estagnada, onde se destaca apenas o município de Paraisópolis.

$\mathrm{Na}$ pesquisa de Andrade todos os municípios estudados apresentaram melhorias em seu IDH no período de 1970 até 2000.

\begin{tabular}{lllll}
\multicolumn{1}{c}{ Municípios } & $\mathbf{1 9 7 0}$ & $\mathbf{1 9 8 0}$ & $\mathbf{1 9 9 1}$ & $\mathbf{2 0 0 0}$ \\
Poços de Caldas & 0,57 & 0,72 & 0,79 & 0,84 \\
Varginha & 0,52 & 0,74 & 0,79 & 0,82 \\
Pouso Alegre & 0,50 & 0,72 & 0,79 & 0,83 \\
Passos & 0,44 & 0,71 & 0,77 & 0,80 \\
Itajubá & 0,51 & 0,73 & 0,81 & 0,81 \\
Lavras & 0,48 & 0,72 & 0,78 & 0,82
\end{tabular}

Tabela 8: Evolução do Índice de Desenvolvimento Humano em municípios do Sul de Minas. Dados da Fundação João Pinheiro. Fonte: Andrade (2003).

Apesar da melhoria apresentada à evolução do IDH, Andrade (2003) mostra que o processo de urbanização apresenta algumas mazelas quando se observa os resultados da ocupação humana no espaço Geográfico. Entre estas mazelas podem ser destacadas: a ocupação de áreas inaptas e a desigualdade social que reflete uma desigualdade espacial embora menos expressiva que nas metrópoles. Referindo-se a Itajubá e Pouso Alegre destaca a ocupação de áreas em solos aluviais o que propicia a ocorrência de enchentes e afirma que mesmo com as conseqüências das cheias os locais inadequados continuam sendo progressivamente ocupados.

Algumas iniciativas têm sido tomadas para que o desenvolvimento econômico desta região tenha menor impacto em seus aspectos ambientais, tais como: a consolidação do Corredor Ecológico da Mantiqueira, promovido pelo IBAMA; a 
própria atuação do Comitê de Bacia Hidrográfica do Sapucaí e ainda algumas iniciativas de Organizações Não Governamentais (Ongs.) da região. Entretanto os resultados ainda são muito pouco expressivos em termos de recuperação e conservação ambiental, pois estas iniciativas são muito recentes.

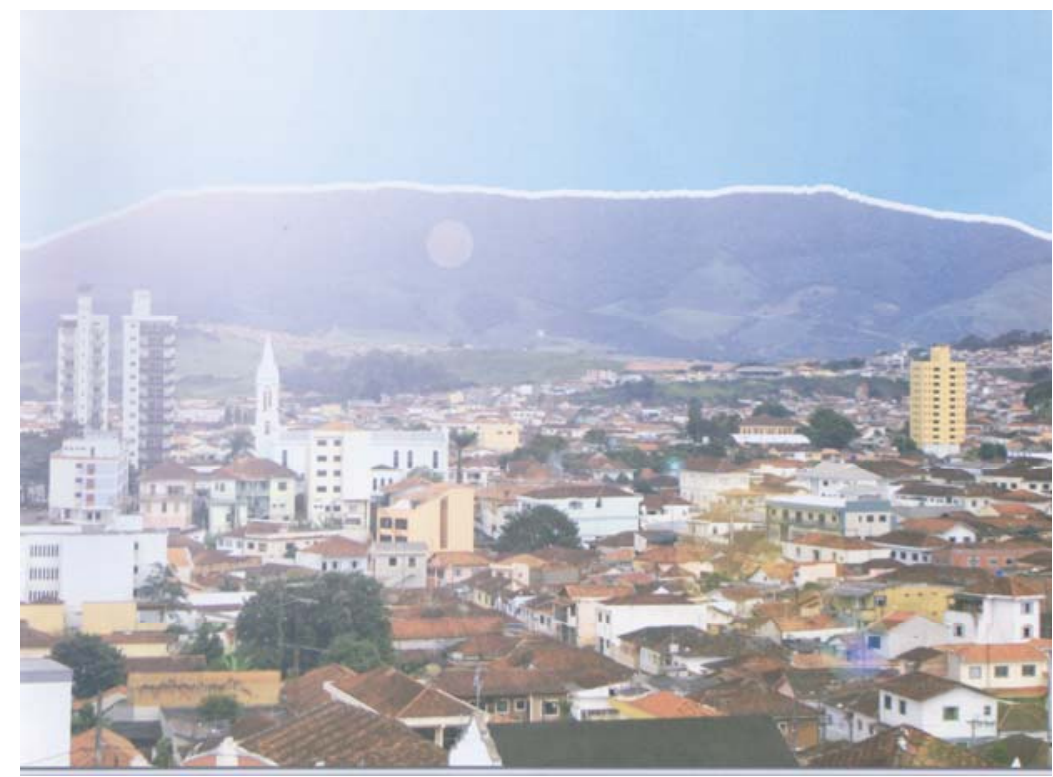

Figura 31: Cidade de Santa Rita do Sapucaí.

Fonte: Câmara Municipal de Santa Rita do Sapucaí, panfleto, 2003.

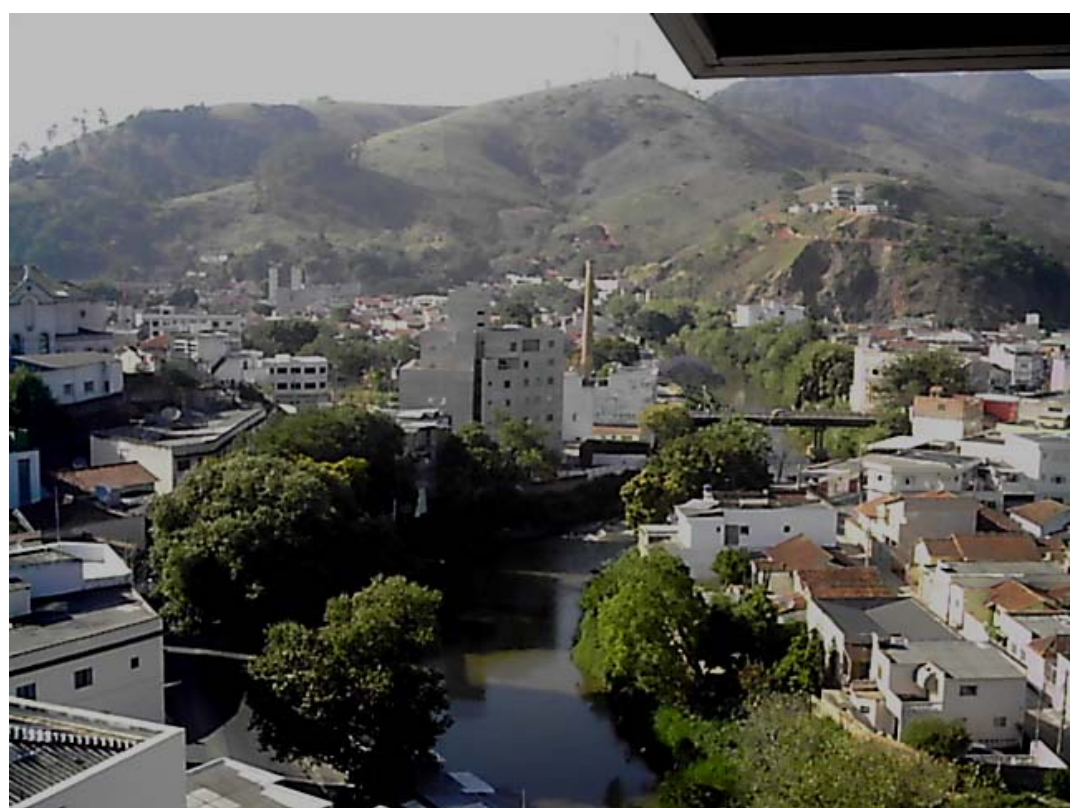

Figura 32: Ocupação na área central de Itajubá: extrema proximidade com o Rio Sapucaí. Foto: Helena M. Faria, 2007. 


\subsubsection{2 - Potencial Econômico e riscos de impactos ambientais crescentes ao longo do Vale do Sapucaí}

De maneira geral pode-se dizer que as cidades do Vale do Sapucaí, que são considerados seus pólos (Pouso Alegre, Santa Rita do Sapucaí e Itajubá):

- Têm como eixo de desenvolvimento a BR 459, que já foi considerada em 2004, a pior estrada em estado de conservação no Brasil, pela Comissão Nacional de Transportes, mas que hoje foi recuperada e na maioria de seus trechos apresenta bom estado de conservação;

- Apresenta Índice de Desenvolvimento Humano alto e alta taxa de população urbana;

- Vive as voltas com problemas de enchentes pela ocupação às margens do Rio Sapucaí.

- Apresenta desenvolvimento tecnológico que pode ser aproveitado em sua estratégia de desenvolvimento 
CAPÍTULO 4

\section{OS CIRCUITOS TURÍSTICOS COMO PROJETOS DE DESENVOLVIMENTO PARA O ALTO E MÉDIO SAPUCAÍ}

"Perguntais por que moro na verde montanha. Intimamente sorrio, mas não posso responder. As flores do pessegueiro são levadas pela água do rio... Há outro céu e outra terra, para além do mundo dos homens."

Li Pó, Séc. VIII.

(Poemas Chineses, Tradução de Cecília Meireles, 1996)

\section{1 - História, Cultura e Preservação Ambiental no Alto e Médio Sapucaí}

\subsection{1 - Referências históricas de Minas Gerais, da Estrada Real e da Região do Alto e Médio Sapucaí}

A história de Minas Gerais, na sua origem, é a história da procura por ouro e por diamantes. Desde o primeiro século após o descobrimento do Brasil, várias estradas foram feitas o que permitia as incursões que tinham como objetivo a busca do ouro, mas, que, acabavam por acarretar não a ocupação, mas o despovoamento da região, uma vez que nestas incursões muitos indígenas eram capturados e levados como escravos para fazendas em São Paulo ou no nordeste brasileiro, e os exploradores partiam em busca de mais minérios preciosos (RODRIGUES, 2003).

A ocupação do território mineiro começou com a bandeira de Fernão Dias Paes, no último quartel do século XVII, e com "bandeira das esmeraldas", a partir de 1674, tiveram início às primeiras manifestações de povoamento por europeus, em 
aldeamentos que serviam como ponto de parada para os bandeirantes. Na última década dos seiscentos teve início o verdadeiro povoamento de Minas Gerais. Nos últimos anos do século XVIII, começou a corrida do ouro que atraiu populações provenientes da Bahia, do Rio de Janeiro e também de Portugal. Os caminhos mineiros se encheram de pessoas de todos os estamentos e profissões, aventureiros e sertanistas, ascendendo à cobiça geral. Surgiram, da noite para o dia, povoados junto às datas de mineração, destacando-se as vilas de ouro (Mariana, Ouro Preto, Sabará, São João Del Rey, Caeté, Pitangui, Serro Frio) (RODRIGUES, 2003).

Em Minas Gerais não existia somente um único Sertão, mas vários. O Sertão da Mantiqueira representava área perigosa onde os grupos indígenas (Coroados, Puris e Carapós), a região densa e acidentada de mata atlântica, e a presença de salteadores, se constituíam em obstáculos até mesmo para aqueles que desejassem apenas passar por seus caminhos. A região da Mantiqueira também era um ponto nevrálgico na Capitania por estar na fronteira. Sendo assim seus caminhos foram proibidos, durante o século XVIII, e sua ocupação foi feita à revelia da Lei de maneira fortuita por posseiros e sertanistas (RODRIGUES, 2003).

\subsubsection{1 - Estrada Real}

Segundo Santos (2001) a Estrada Real foi um dos poucos caminhos autorizados pela Coroa Portuguesa às regiões de reserva de ouro e diamante na capitania de Minas Gerais. Nestes caminhos circulavam pessoas, mercadorias, pedras preciosas e demais iguarias, sendo proibido a abertura de novos caminhos. A base da política metropolitana para essas regiões mineradoras da colônia era o 
interesse fiscal. As rotas de comunicação com as minas eram amplamente controladas e fiscalizadas para a obtenção de maior riqueza à coroa. A Estrada Real era propriedade da Coroa Metropolitana e foi o centro das atenções enquanto os ciclos do ouro e do diamante estavam no auge. Com o esgotamento das minas nos séculos XVIII e XIX, os caminhos reais tornaram-se livres de fiscalização e serviram para comunicação entre as regiões do centro-sul do território colonial.

A história do povoamento do interior brasileiro está vinculada à abertura das rotas terrestres e fluviais que varreram o território a partir do século XVI, milenares caminhos indígenas foram utilizados para o avanço dos bandeirantes para a captura de índios e pesquisa mineralógica. Com a chegada dos africanos, os caminhos passaram a ser também obra do escravo negro. Em Minas Gerais estabeleceram-se caminhos de pedra, vias por onde trafegavam tropas de burros, transportando ouro e diamantes para os portos litorâneos, e, no caminho inverso, abastecendo o interior de alimentos, roupas, armas, pólvora, aguardente, e ferramentas muitas vezes trazidas da Europa (SANTOS, 2006).

A expansão originária dos primeiros grandes caminhos do centro-sul do território colonial conformou um dos mais significativos movimentos de apropriação do interior brasileiro e de sua integração com a faixa litorânea.

O nome Estrada Real passou a aludir às vias que eram de propriedade da Coroa, pois, durante longo tempo, as únicas vias autorizadas de acesso à região das jazidas, de pessoas, mercadorias, ouro e diamante era obrigatoriamente feita por estes caminhos, constituindo crime de lesa-majestade a abertura de novas vias. Durante todo o século XVIII e XIX, quando a mineração já decaíra, estas vias continuaram sendo o tronco principal de quatro capitanias do centro-sul da colônia: Minas Gerais, São Paulo, Rio de Janeiro e Bahia (SANTOS, 2006). 
Tanto tempo de ocupação e utilização levou a denominações diferentes para tão extensa região tracejada por estes caminhos reais. A Rota Estrada Real, objeto de políticas para o desenvolvimento do turismo, por iniciativa do Instituto Estrada Real, entidade sem fins lucrativos criada pela FIEMG (Federação das Indústrias do Estado de Minas Gerais), procura através do resgate do patrimônio histórico, cultural e natural destes caminhos incentivar a atividade turística como forma sustentável de desenvolvimento. Em 1999 foi criado o Programa Estrada Real através da Lei 13.173.

A pesquisa histórica e os esforços para o desenvolvimento do turismo, fizeram com que fossem delimitadas regiões por onde o caminho comprovadamente existiu e regiões de influência, onde outros caminhos foram se estabelecendo ao longo da história. A rota proposta pelo Instituto Estrada Real é composta por mais de 1.400 km e abrange 177 municípios em três estados: 162 em Minas Gerais, 08 no Rio de Janeiro e 07 em São Paulo. Esta rota é dividida nos seguintes seguimentos principais, denominados caminhos:

O Caminho Velho, que liga Ouro Preto a Paraty: é o Caminho mais antigo, sendo que há indícios de sua utilização pelos bandeirantes paulistas já no século $X V I$. Sua utilização se tornou difícil para quem seguia do Rio de Janeiro para as Minas Gerais, sendo que era necessário chegar a Paraty pelo mar, e daí por terra até os entroncamentos paulistas. Para atravessar este percurso poderia se levar até três meses. Sendo assim, o governador da Capitania do Rio de Janeiro, no período de 1697 até 1702, Arthur de Sá Menezes, tomou a iniciativa de organizar a abertura de um novo caminho, o Caminho Novo. (SANTOS, 2006).

O Caminho Novo, que liga o Rio de Janeiro a Ouro Preto: em 1700, o sertanista Garcia Rodrigues, contratado pelo governador do Rio de Janeiro, 
conseguiu concluir o caminho para pedestre passando a melhorá-lo posteriormente, para a passagem de animais de carga. Em algumas décadas o Caminho Novo se torna o principal acesso do litoral sul às Minas Gerais. Sua consolidação provocou mudanças no contexto político e econômico, com a centralização da rota na cidade do Rio de Janeiro, com o fim da supremacia paulista nas minas. No século XVIII, este caminho se tornou via privilegiada para a propagação das idéias libertárias da inconfidência mineira (SANTOS, 2006).

O Caminho dos Diamantes: o caminho existente nos séculos XVIII e XIX entre Vila Rica e o Arraial do Tijuco, sede do Distrito Diamantino, atual Diamantina, constituía via de amplitude regional. Por ele se fazia a ligação entre a sede da capitania e a região que, no início do século XVIII, passou a fornecer as pedras mais cobiçadas da época (SANTOS, 2006).

A figura 35 ilustra os caminhos da Estrada Real propostos pelo Instituto Estrada Real.

Márcio Santos (2006) ressalta que o interesse de pesquisadores e o desenvolvimento de diversos projetos de desenvolvimento para os Caminhos Reais, não garantem, por si só, um futuro promissor para estas regiões, sendo necessário um compromisso dos governos, em suas diversas instâncias e o envolvimento das comunidades, pois a proteção ao patrimônio cultural é ainda novidade no Brasil. 


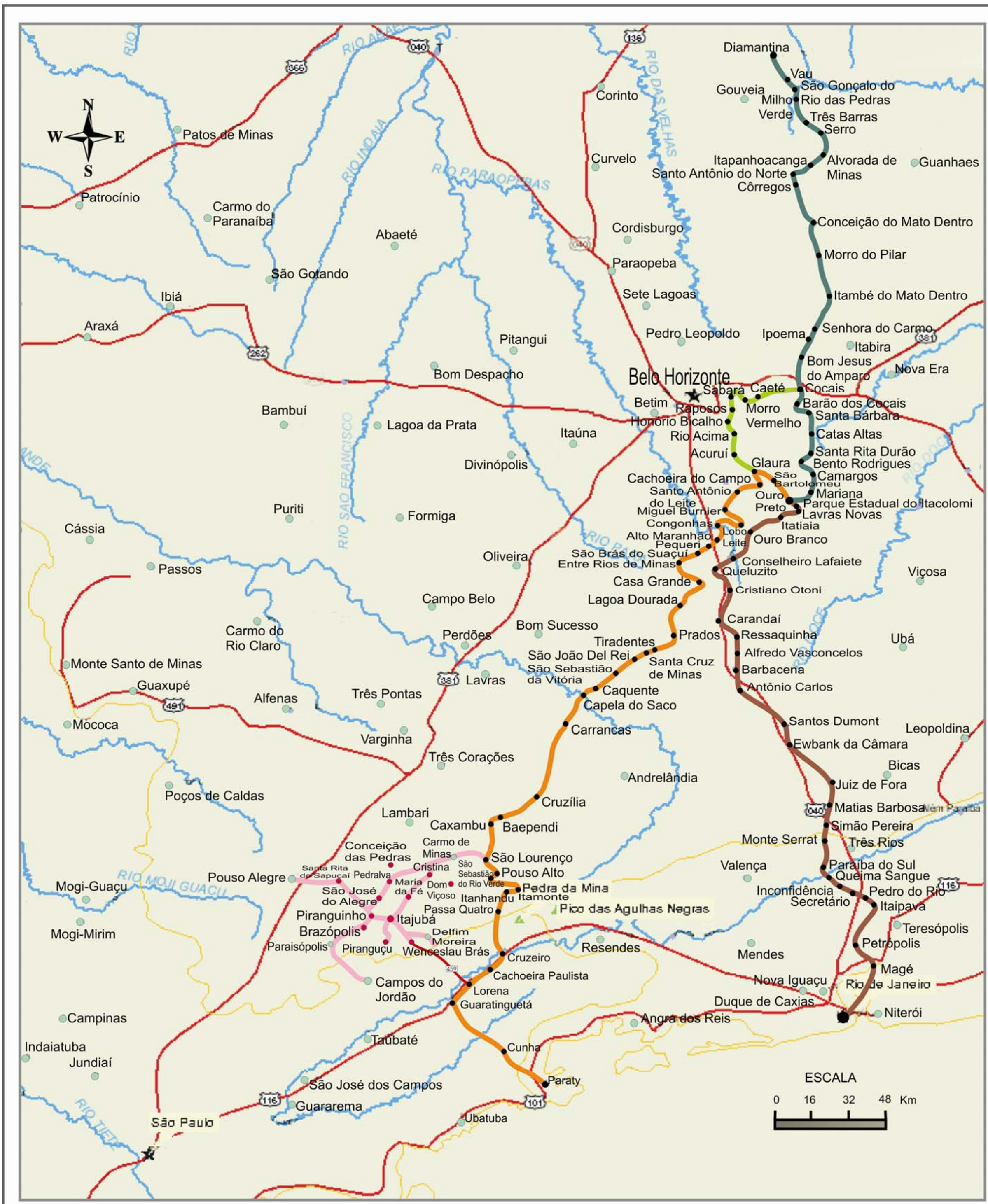

\section{Legenda}

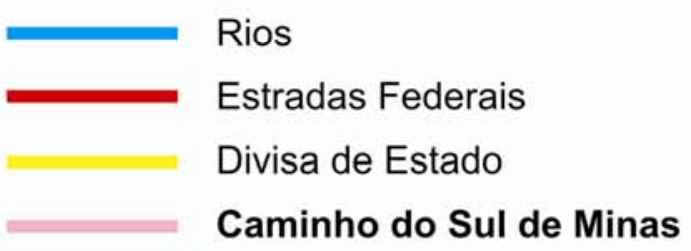

Elaboração: PEREIRA, Elaine C; FARIA, Helena M.: PAES, Fernanda $S$.

Fonte: www.ibge.gov.br/mapasinterativos www.estradareal.org.br/mapapress

\section{Estrada Real}

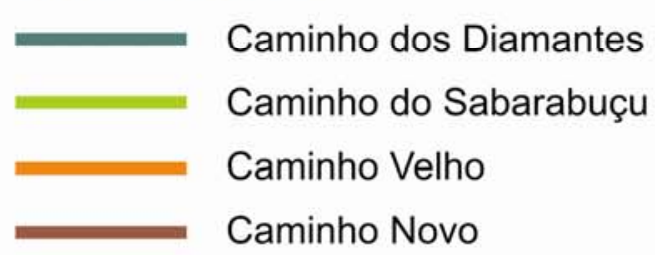

- Cidades do Roteiro da Estrada Real

- Cidades do Circuito Turístico Caminhos do Sul de Minas

Outras cidades 


\section{2 - Circuitos Turísticos ao longo da Estrada Real e na Região do Alto e Médio Sapucaí}

$\mathrm{Na}$ atualidade o desenvolvimento de um circuito turístico pode representar muito para municípios que não encontram chances de crescimento em outras atividades como a agropecuária e a indústria, ou já estão demasiadamente degradados por estas mesmas atividades. Ao mesmo tempo deve-se pensar em que tipo de turismo pretende-se incentivar, e a quem esta atividade irá beneficiar. Experiências antigas de desenvolvimento turístico no Brasil apontam para o perigo de se separar o crescimento desta atividade do crescimento da qualidade de vida da população local, que inclui o respeito à sua cultura, mas também ao espaço que ocupa. Muitas experiências levaram a uma separação tão grande entre áreas de turismo e áreas das populações locais em determinados locais, que problemas como a violência e a falta de segurança acabam por minar as perspectivas e os investimentos feitos.

A Rota Estrada Real representa uma oportunidade de desenvolvimento muito grande para os municípios que a integram e também para municípios vizinhos. É uma rota muito extensa, e, por isso mesmo, apresenta uma riqueza cultural e de paisagens surpreendente. Analisando-se uma região extensa como esta, o risco de se perder algumas particularidades essenciais é muito presente, mas neste trabalho pretende-se realizar o esforço de, em uma análise em escala regional, não se perder os detalhes que possam fazer diferença nas reflexões propostas.

Se bem administrado e articulado com as necessidades de desenvolvimento das comunidades onde se situa, a Rota Estrada Real pode representar 
oportunidades para o desenvolvimento econômico, a sustentabilidade ambiental e cultural das regiões por onde perpassa.

\subsection{1 - Circuitos turísticos no Caminho Velho da Estrada Real: intersecções com a região do Alto e Médio Sapucaí}

Um Circuito Turístico é composto por municípios próximos entre si, que se associam em função de interesses e possibilidades de explorar turisticamente seus respectivos patrimônios históricos, culturais e naturais, assim como outros bens afins. É indispensável que pelo menos um desses municípios disponha da infraestrutura necessária para receber turistas, de modo que estes, a partir dali, possam desfrutar os atrativos dos demais.

Em Minas Gerais, a idéia de se agrupar municípios em Circuitos Turísticos veio da necessidade de explorar melhor o potencial do Estado nesse setor, sendo que, no final dos anos de 1990, à medida que se estimulava as tradicionais cidades e localidades turísticas de Minas a promover uma revisão de seus posicionamentos e ações em relação ao turismo, vislumbrava-se a geração de oportunidades também para os municípios vizinhos. Estes passariam não só a explorar suas respectivas potencialidades, mas também a contribuir para a diversificação da atratividade e ou da infra-estrutura turística de sua região. Este processo liderado pelo governo do Estado, tem contado com a parceria de governos municipais e de outras organizações interessadas no desenvolvimento turístico. O governo federal também tem apoiado estas iniciativas, através do Ministério do Turismo.

Ao longo do caminho velho da Rota Estrada Real, parte do caminho que perpassa a região do Alto e Médio Sapucaí, objeto desta pesquisa, percebe-se a 
existência de circuitos turísticos que se mesclam. Este fato pode ser positivo por representar iniciativas de governos para o desenvolvimento turístico, mas também pode causar uma diversidade de informações que, muitas vezes, confunde a verdadeira identidade local, que se pretende consolidar para o desenvolvimento do turismo.

Os circuitos existentes ao longo do Caminho Velho e próximos a região estudada são os seguinte:

Circuito das Águas: região turística tradicional no Sul de Minas, composta pelos municípios: Baependi, Cambuquira, Campanha, Caxambu, Carmo de Minas, Heliodora, Lambari, São Lourenço, Conceição do Rio Verde e Soledade de Minas. Esta região foi portão de entrada para os bandeirantes no final do século XVIII, e, várias de suas cidades apresentam vestígios do Ciclo do Ouro. A atividade turística é muito intensa, sendo que pode se considerar existente desde a época imperial. Entretanto como parte de uma política de reestruturação da atividade turística em Minas Gerais, este circuito passou a ser um circuito certificado em 2005 pela Secretaria Estadual de Turismo. Todos os seus municípios integram a área de influência da Estrada Real, com exceção de Campanha e Heliodora, sendo que os municípios de Baependi, Caxambu, São Lourenço fazem parte do Caminho Velho, demarcado.

Circuito Turístico Caminhos do Sul de Minas: Constituído por Brasópolis, Conceição das Pedras, Cristina, Dom Viçoso, Itajubá, Maria da Fé, Pedralva, Piranguçu, Piranguinho, São José do Alegre e Santa Rita do Sapucaí, aposta no desenvolvimento do turismo rural, histórico e natural, apoiada em suas características de região produtora de café e leite, em regiões preservadas, e nas características culturais que traduzem a hospitalidade mineira. Este circuito foi 
certificado em 2006 pela Secretaria Estadual de Turismo e possui uma agência de desenvolvimento. Os municípios de Cristina, Dom Viçoso, Pedralva, Maria da Fé, e Wenceslau Braz, fazem parte também da área de influência da Rota Estrada Real. Os municípios de Piranguçu e Wenceslau Braz também integram a APA (Área de Proteção Ambiental) da Serra da Mantiqueira. Todos os municípios deste circuito fazem parte da Bacia Hidrográfica do Sapucaí.

Circuito Turístico Terras Altas da Mantiqueira: composto pelos municípios de Alagoa, Delfim Moreira, Itamonte, Itanhandú, Marmelópolis, Passa Quatro, Pouso Alto, São Sebastião do Rio Verde e Virgínia, este circuito tem como atrativos principais o clima frio de montanha e as belezas naturais de áreas preservadas. Todos os municípios deste circuito, com exceção de São Sebastião do Rio Verde são integrantes da APA da Serra da Mantiqueira. Todos os municípios também pertencem à Rota Estrada Real. Os municípios de Delfim Moreira, Marmelópolis e Virgínia integram a Bacia Hidrográfica do Sapucaí. 


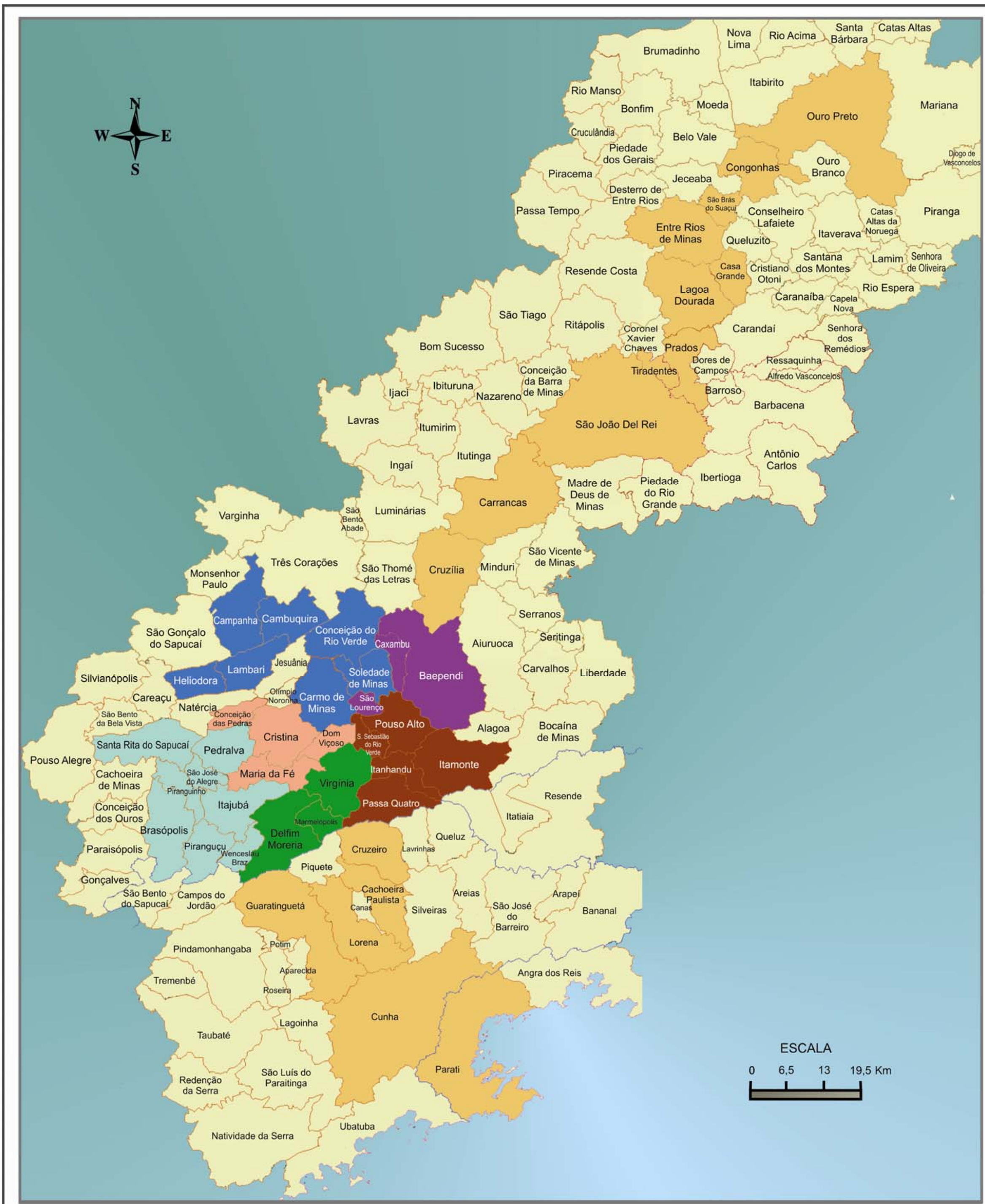

\section{Legenda}

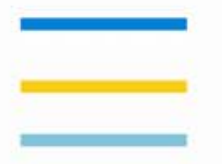

Divisa de estado

Municípios da Estrada Real (caminho velho)

Municípios do Circuito Turístico "Caminhos do Sul de Minas"

Municípios do Circuito Turístico "Caminhos do Sul de Minas" e Estrada Real Outros municípios
Municípios do Circuito "Terras Altas da Mantiqueira"

Municípios do Circuito "Terras Altas da Mantiqueira" e Estrada Real

Municípios do Circuito "Turístico das Águas"

- Municípios do Circuito "Turístico das Águas" e Estrada Real

Divisão Territorial dos Municípios dos Circuitos Turísticos

Elaboração: PEREIRA, Elaine C; FARIA, Helena M.; PAES, Fernanda S. Fonte: http://mapas.ibge.gov.br/divisão

Figura 34: Mapa de todos os Circuitos Turísticos do Caminho Velho percorrido. 


\section{3 - Observações sobre pontos percorridos no Caminho Velho da Estrada Real}

Como atividades de pesquisa para este trabalho foram realizadas pequenas viagens por alguns pontos da Estrada Real, na área que circunscreve o Caminho Velho. Nestas viagens foram realizados levantamentos fotográficos e entrevistas informais, efetuadas aleatoriamente com turistas e moradores dos pontos visitados. Sendo assim, foi possível verificar algumas questões referentes às perspectivas para o planejamento ambiental para a região estudada, gerando também uma visão mais abrangente do que pode significar esta grande rota turística, a Estrada Real, bem como os outros circuitos que a intercedem.

As visitas realizadas foram aos seguintes pontos da Estrada Real:

A. Itajubá-Cunha: Partindo de Itajubá-MG, foi realizado levantamento fotográfico até a cidade de Cunha-SP, passando pelas cidades de Delfim Moreira-MG, Piquete-SP, Lorena-SP, Guaratinguetá-SP, passando pela BR 459 que liga Poços de Caldas-MG a Lorena-SP, pela Rodovia Presidente Dutra e pela estrada que liga Guratinguetá-SP à Cunha-SP. As fotografias foram realizadas no trajeto de ida e volta. Esta viagem foi realizada entre 30 de dezembro de 2005 e 01 de janeiro de 2006.

B. Itajubá-Caxambú: Partindo de Itajubá-MG, o trajeto percorrido incluiu a cidade de Piranguinho-MG, Pedralva-MG, São Lourenço-MG e Caxambu-MG, as duas primeiras cidades pertencentes ao Circuito Turísticos Caminhos do Sul de Minas e as duas últimas pertencentes à Rota Estrada Real. O trajeto de volta foi realizado pelas seguintes cidades: Caxambu-MG, São Lourenço-MG, CristinaMG e Maria da Fé-MG. Foi realizada em Maio de 2005. 
Os trajetos percorridos possibilitaram a vivência da Estrada Real, que, na verdade esconde muito mais do que o slogam de uma rota turística: nela sente-se a cultura e a degradação, os caminhos e descaminhos de uma porção do território brasileiro. Os caminhos, as estradas são muitas vezes formas de se alavancar desenvolvimento econômico, mas a Estrada Real, em sua origem representava uma forma de exploração econômica, da colônia pela metrópole, primeiramente, e posteriormente o acesso às riquezas do interior do sertão, na maior parte das vezes firmando-se como um caminho para a evasão dessas mesmas riquezas. A barreira formada pela Mantiqueira desafia, confina, separa, e surpreendentemente protege, em alguns pontos, o ambiente natural, por longos anos. Como outras regiões brasileiras, a história destes caminhos traz mazelas e alegrias, e, acima de tudo contradições entre etnias e classes. É necessário entendê-lo não mais como uma rota de exportação de riquezas, mas como um caminho que proporcione desenvolvimento econômico-social aliado às práticas ambientalmente equilibradas.

\subsection{1 - Referências Históricas, Culturais e Paisagísticas do Trajeto A — Itajubá-Cunha}

Partindo-se de Itajubá-MG, cidade não integrante mais muito próxima da Rota Estrada Real, chega-se a Delfim Moreira-MG, pertencente à APA da Serra da Mantiqueira, integrante de outro circuito turístico denominado Terras Altas da Mantiqueira, e da área de influência da Rota Estrada Real. Sua história se confunde com a de Itajubá, uma vez que foi descoberta em 1723, e inicialmente chamou-se Minas de Itagyba, nome indígena, que significa água que brota da pedra. Exauridas as explorações de ouro esta freguesia entrou em decadência e a maior parte de sua 
população migrou para outros pontos, principalmente para a então Vila da Boa Vista de Itajubá, localidade onde hoje se situa Itajubá. Possui população predominantemente rural (5.360 habitantes), sendo que a população urbana é de apenas 2.672 habitantes, segundo o censo do IBGE do ano 2000. Apresenta atrativos naturais muito peculiares, principalmente cachoeiras e áreas montanhosas ainda preservadas na Serra da Mantiqueira.

Passando pela rodovia BR 459, a Rodovia Juscelino Kubichek tem-se um cenário de extrema riqueza em biodiversidade, e, descendo-se a serra, em direção à cidade de Piquete-SP, em alguns pontos observa-se grande parte do Vale do Paraíba. A estrada em alguns pontos apresenta estado de conservação precário.

Chegando a Lorena-SP, a paisagem do vale prevalece, mas vê-se atrás a Mantiqueira imponente, protegida em suas áreas de topo, mas tomada totalmente por pastagens nas áreas mais baixas.

Lorena é uma cidade com população urbana de 74.948 habitantes, e, rural de 2.895 habitantes, segundo CENSO 2000 do IBGE. Situada às margens da Rodovia Presidente Dutra, considerada no século XIX Vila de pouca importância, teve crescimento econômico posterior por apresentar terras muito férteis, porém não propícias ao cultivo do café e da cana-de-açúcar.

Chegando em Guaratinguetá depara-se com uma cidade bem situada as margens da Rodovia Presidente Dutra, com população predominantemente urbana, com 98.964 habitantes na área urbana e 5.058 habitantes na área rural (CENSO 2000, IBGE). Povoação das mais antigas da Província foi fundada em 1641, e possui muitas construções históricas (www.estradareal.org.br).

Na estrada para Cunha-SP, a sensação de descer a Serra se renova e é visto ao longe a Serra da Bocaina em toda sua magnitude. Em 1822, Saint Hilaire, em 
viagem a Cunha menciona que ali começaria a funcionar uma barreira fiscal e afirmava ainda que, como a vila de Cunha se situava em terreno baixo, o café e o açúcar não progredia em suas redondezas, sendo que outros produtos, principalmente o milho eram cultivados.

Hoje com população urbana (11.110 habitantes) e rural (11.952) praticamente equivalentes, segundo Censo do IBGE de 2000, a cidade de Cunha se estrutura para se tornar um pólo turístico, através da preservação de edifícios históricos, da manutenção das festas e tradições populares, e da exploração de atrativos naturais, cachoeiras, e do Parque Nacional da Serra da Bocaina, assim como de sua proximidade da cidade de Paraty, no litoral sul fluminense. A estrada Cunha-Paraty não é pavimentada. Este fato é polêmico, pois ao mesmo tempo em que mantém preservada área da Serra da Bocaina, diminui a possibilidade de fluxo de turistas entre as duas cidades.

Uma bacia em forma de ferradura ocorre na região de Cunha, onde se unem as Serras da Bocaina, Quebra-Cangalha e Serra do Mar, por onde corre o Rio Paraitinga, apresentando um belíssimo vale de nascentes que se estende pelas vertentes paulista da Serra da Bocaina, que é cortada por estradinhas de terra batida que se cruza subindo e descendo as dobraduras das montanhas cobertas de pastagem, habitações rurais de gente simples e trechos ainda remanescentes da Mata Atlântica (www.estradareal.org.br).

Henrique A. Prudente (2005), em estudos sobre o turismo em Cunha, faz uma reflexão sobre a necessidade de se garantir um tipo de turismo emancipador, permitindo a manutenção do que chama de culturas subalternas, ou seja, aquelas não totalmente dominadas pelas classes hegemônicas, por sua concepção de 
Os circuitos turísticos como projetos de desenvolvimento para o Alto e Médio Sapucaí

mundo e ideologia, mais presentes neste início de século, pela influência do fenômeno da globalização.

Tendo como referência o trabalho de Prudente (2005) esta cultura subalterna se revela como sendo a cultura não oficial, e se respeitada pode garantir preservação e desenvolvimento a municípios sob influência da Rota Estrada Real. 


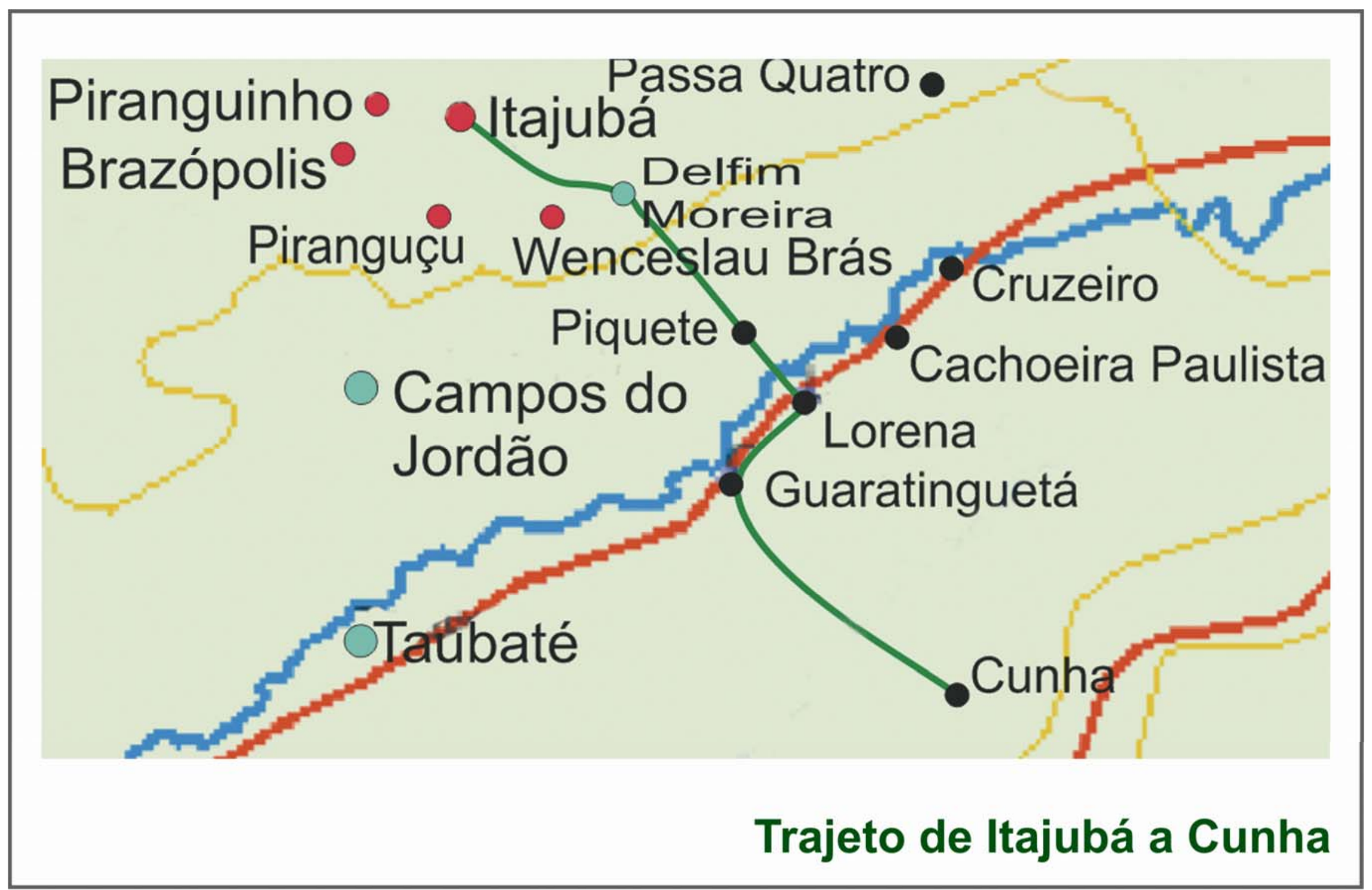

Figura 35: Mapa do Trajeto A: Itajubá-Cunha 


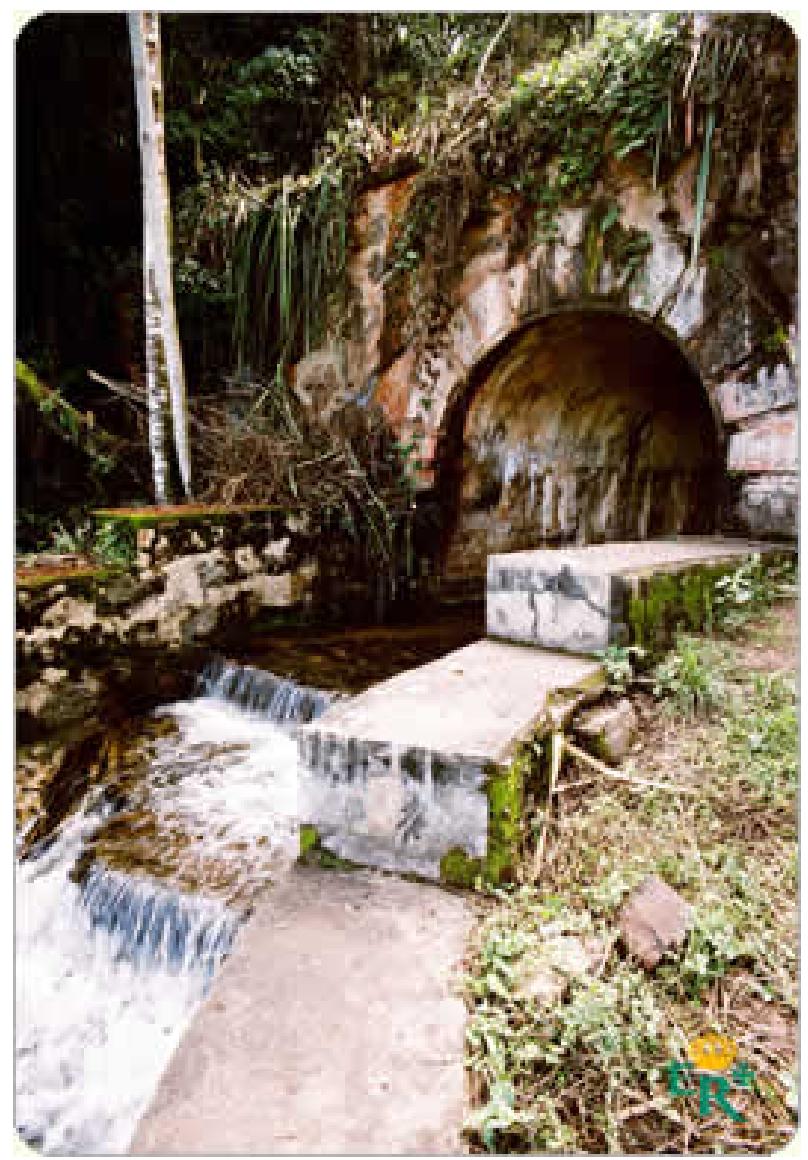

Figura 36: Túnel do Barreirinho em Delfim Moreira-MG construção da década de 1920,

em estilo eclético, que fazia parte do antigo ramal da rede mineira de viação (www.estradareal.org.br). Fonte: www.estradareal.org.br.

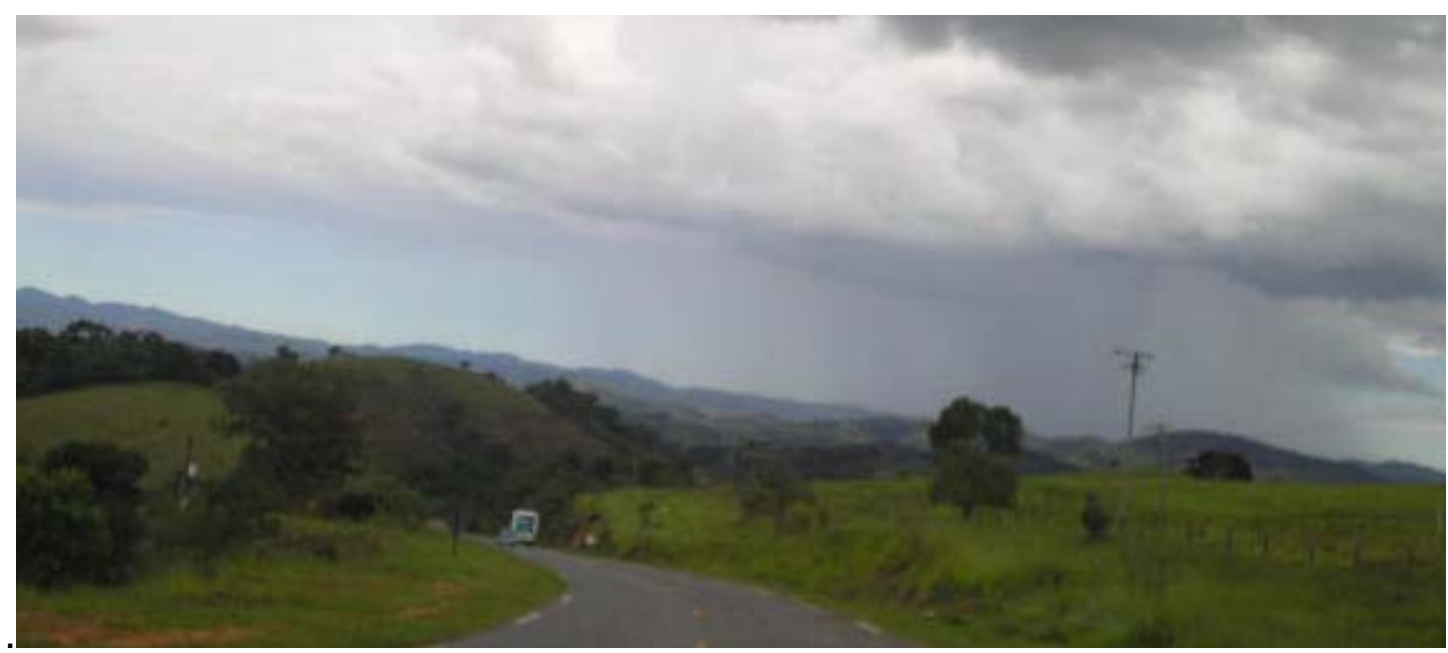

Figura 37: Trecho entre Guaratinguetá-SP e Cunha-SP, visão da Serra da Bocaina ao fundo. 


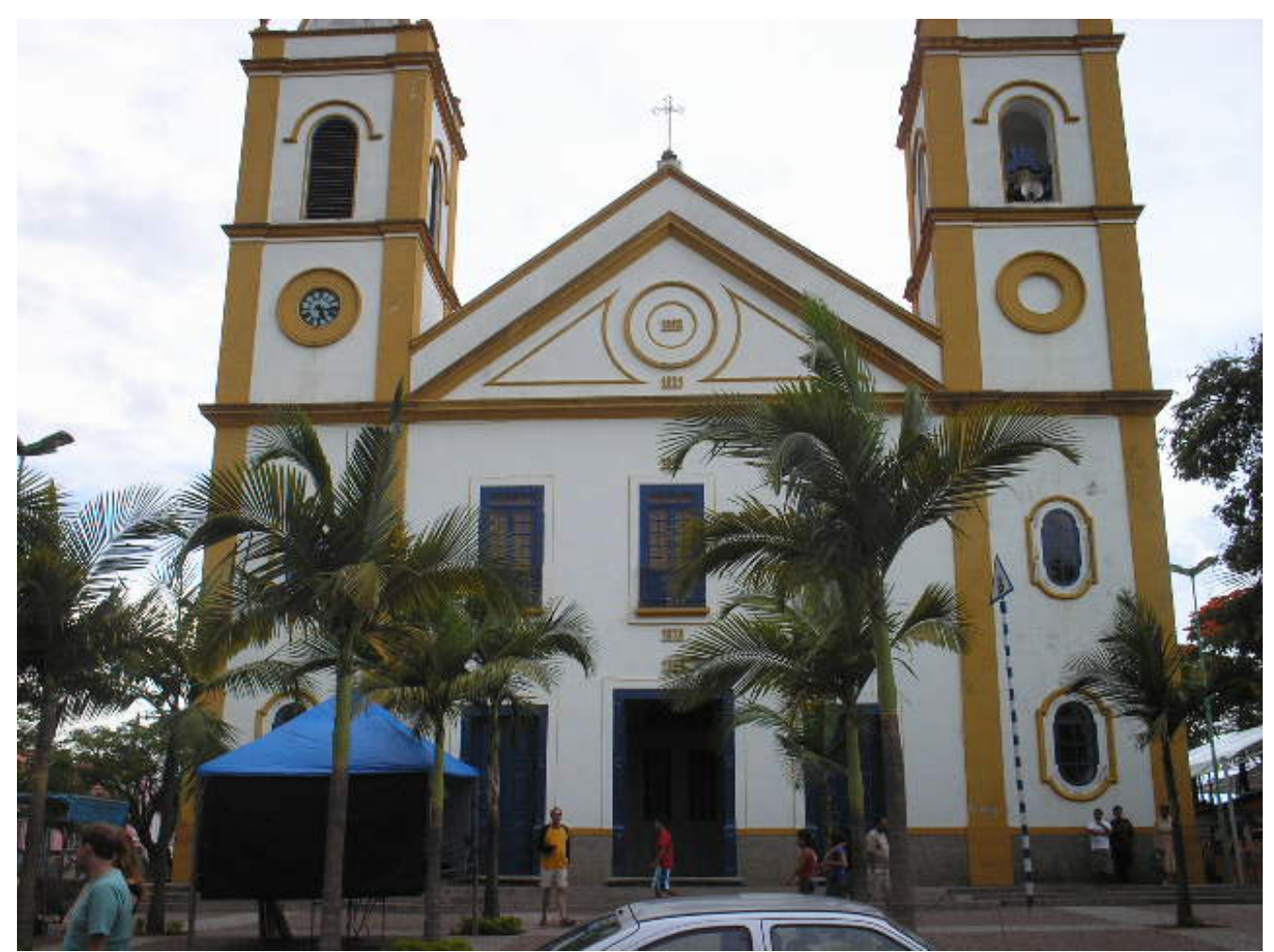

Figura 38: Igreja Matriz Nossa Senhora da Conceição, na praça central de Cunha-SP, construída em 1731 é um exemplo do barroco paulista.

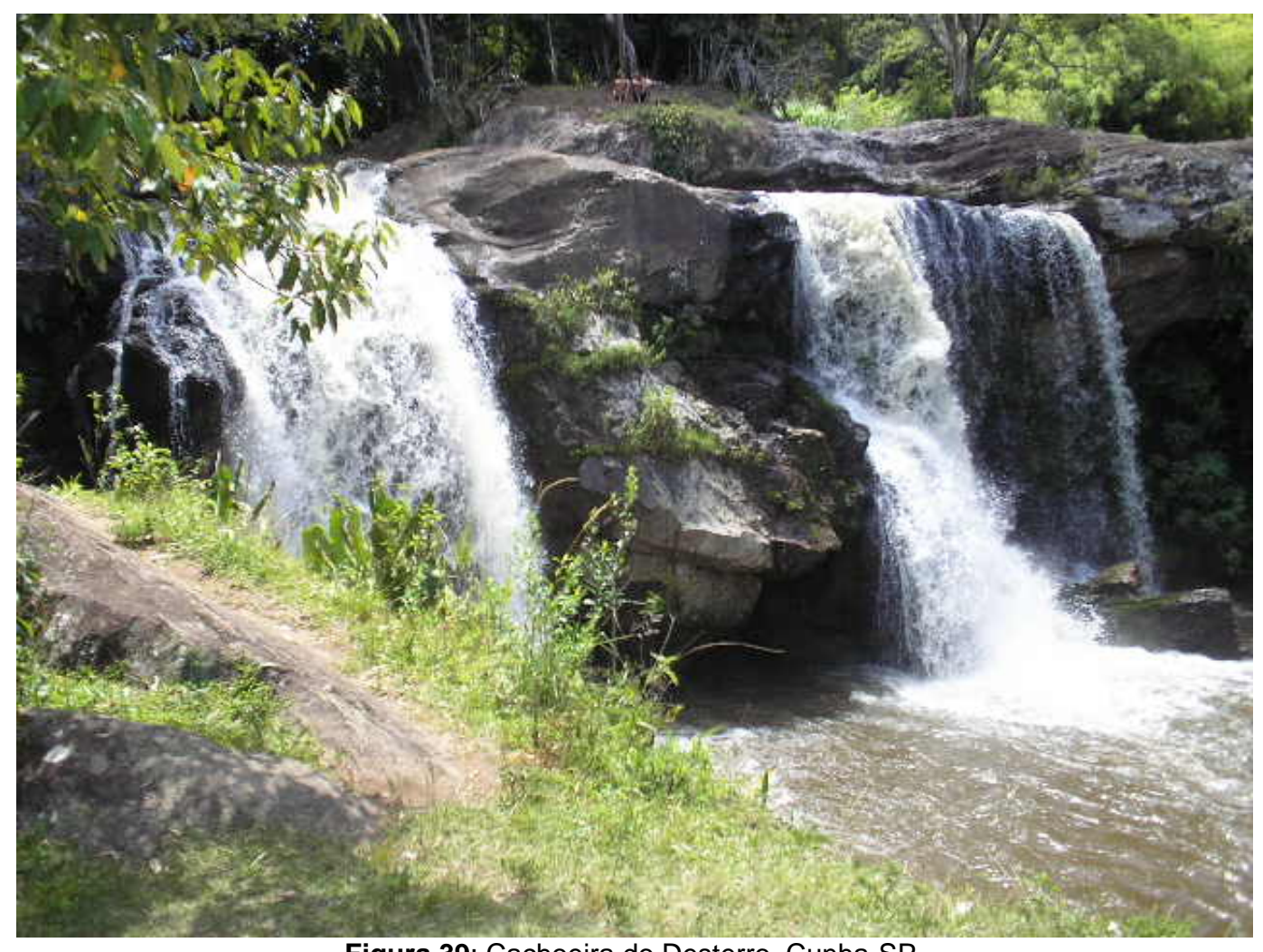

Figura 39: Cachoeira do Desterro, Cunha-SP. 


\subsection{2 - Referências Históricas, Culturais e Paisagísticas do Trajeto B — Itajubá-Caxambú}

Partindo-se de Itajubá, o trajeto percorrido incluiu as cidades de Piranquinho e Pedralva, em Minas Gerais, pertencentes ao Circuito Turísticos Caminhos do Sul de Minas, sendo que somente Piranguinho não pertence à Rota Estrada Real. Passando por São Lourenço e Caxambu, cidades do Circuito das Águas e também da Rota Estrada Real. O trajeto de volta foi realizado pelas seguintes cidades: Caxambu, São Lourenço, Cristina e Maria da Fé, todas integrantes da Rota Estrada Real, sendo que Cristina e Maria da Fé também pertencem ao Circuito Turístico Caminhos do Sul de Minas. Itajubá, Piranguinho, Pedralva, Cristina e Maria da Fé são municípios da Bacia Hidrográfica do Sapucaí.

\section{Piranguinho}

O município de Piranguinho é conhecido como a capital nacional do Pé-deMoleque, doce típico feito de amendoim e rapadura. Seu nome em tupi significa peixe pequeno, referência a grande quantidade de peixes miúdos as margens do Rio Sapucaí, que cruza a cidade.

Piranguinho iniciou sua história no final do século XIX, quando o Brasil ainda era um Império governado por D. Pedro II. A região, onde atualmente se localiza o município, até meados do século XIX, era propriedade da Baronesa Leocádia de Lourenço e estava subordinada a São Caetano da Vargem Grande - atual Brasópolis. Com o passar do tempo, a localidade acabou se tornando alvo de interesse por parte das autoridades responsáveis em desenvolver o projeto "Rede Mineira de Viação". Tal empreendimento visava à construção de uma estrada de ferro que ligasse Itajubá a Santa Rita do Sapucaí, estendendo a malha ferroviária a outras regiões do estado. Na referida época, a região era provida de ricas matas que 
continham madeiras de lei. Apesar das divergências documentais a respeito da data em que são iniciadas as obras, sabe-se que a ferrovia começou a ser construída nos primeiros anos da década de 1880. A necessidade de trabalhadores para a empreitada naturalmente atraiu um número significativo de pessoas, dando origem, assim, a uma pequena povoação (www.prefeiturapiranguinho.com.br, junho de 2006).

Em 1910 Dona Maria Paulina de Noronha, a popular "Nenê Paca", construiu na Estação Férrea de Piranguinho um botequim onde eram vendidos os afamados Pés-de-Moleque (www.prefeiturapiranguinho.com.br, junho de 2006).

A população estimada segundo o censo do IBGE é de 8.044 habitantes distribuídos em uma área de 130 km² (www.ibje.gov.br/cidades, junho de 2006).

Os atrativos naturais, aliados a culinária, têm feito da cidade palco de um turismo regional ligado principalmente a eventos como a festa do Peão de Boiadeiro, o Encontro de Jipeiros, o Enduro a Pé-de-Moleque e o Encontro de Filosofia.

\section{Pedralva}

Outro município visitado foi Pedralva, que com uma população estimada em 12.642 habitantes em 2005 e uma área de 217 km², segundo dados do IBGE, possui atrativos naturais, atraindo o turismo de aventura, principalmente pela prática do montanhismo realizada principalmente na imponente Pedra do Pedrão, que também é utilizada para prática de vôo livre. É uma região montanhosa e com remanescentes de mata atlântica.

Partindo-se de Pedralva com direção a cidade de São Lourenço pela Rodovia MG 347, são avistadas plantações de café e banana, em áreas montanhosas, e uma paisagem de grande beleza. A cerca de $65 \mathrm{~km}$ de Pedralva está a Estância Hidromineral de São Lourenço, trajeto feito em média em 40 minutos. 


\section{São Lourenço}

São Lourenço tem uma população estimada em 41.348 habitantes segundo dados do IBGE de 2005 e uma área de 57 Km².

Cidade tradicionalmente ligada ao turismo como atividade econômica principal, foi uma das primeiras estâncias hidrominerais do país, sendo que atualmente possui 8.095 pessoas ocupadas no setor de serviços de um total de 15.299 referente à população ocupada.

Com altitudes entre 1.352 m (máxima) e 947 m (mínima), pertence a Bacia do Rio Grande.

O Parque das Águas é o principal atrativo da cidade constituído de seis fontes de água mineral. O lugar anteriormente era conhecido como Água do Viana, em virtude da descoberta em um brejo, de uma fonte de água cristalina, pelo famoso caçador Antônio Francisco Viana. Segundo a tradição oral, a existência das águas minerais e suas propriedades medicinais ganhou domínio público a partir de 1826 . Em 1890, o comendador Bernardo Saturnino da Veiga compra as terras onde se localizava as termas e funda a Companhia das Águas Minerais de São Lourenço, nome dado em homenagem ao pai do proprietário. Com a inauguração da Estação Ferroviária próxima ao local, em 1894, o fluxo de visitantes passou a aumentar, e também aumenta a fama das curas realizadas com o uso das águas. Em 1927, São Lourenço é constituído município (www.estradareal.org.br).

Além do Parque das Águas outros atrativos importantes são: o teleférico de São Lourenço, a Parada Ramon, antiga parada do trem, onde se realiza exposições de artesanato e a Estação Ferroviária inaugurada em 1891, e construída em estilo inglês, hoje reativada, cujo passeio pode ser feito até a cidade de Soledade de Minas, no chamado "trem das águas" (www.saolourençoonline.com.br). 


\section{Caxambu}

Chegando a cidade de Caxambu depara-se com uma das maiores estâncias hidrominerais do mundo, cidade onde já se percebe mais claramente alguns marcos da Estrada Real.

Até o final do século XVII, com a chegada de bandeirantes o Morro de Caxambu, era habitado por índios Cataquases. Caxambu em Tupy significa bolhas a ferver ou água que borbulha. Também existe outra possível origem do nome em duas palavras africanas Cacha (tambor) e mumbu (música), que no século XIX designavam os instrumentos e a própria dança e música dos escravos (www.estradareal.org.br).

Segundo os registros históricos, a povoação, iniciada em 1747, cresceu e transformou-se em vila e, em 1814 foram descobertas as fontes de águas minerais e a partir de então a cidade passou a receber figuras ilustres do Império, e até do exterior, que ali iam fazer estação de águas.

Em 1868 chega a Caxambu a Princesa Isabel, seu esposo Conde D'Eu e uma comitiva, atraídos pela fama das águas. A princesa buscava a cura de uma suposta infertilidade. Ficam durante um mês, partindo em 17 de dezembro. Durante sua estadia foi lançada pela Princesa Isabel, a pedra fundamental da Igreja Santa Isabel da Hungria, com a promessa de sua construção, caso a herdeira viesse a engravidar (www.caxambu.mg.gov.br).

A ligação entre Caxambu e o Antigo Império ficou ainda mais próxima com a Estrada Real.

O ano de 1875 foi de grande importância para o povoado, pois além de tornar-se Distrito de Baependi, as virtudes curativas de suas águas foram reconhecidas, tendo sua exploração concedida pelo governo da Província de Minas 
Gerais a empresas particulares. Nesta época, 1881, a cidade contava com apenas 200 habitantes efetivos, 130 edificações e iluminada por 21 lampiões a querosene.

Em 16 de setembro de 1901 é criada a Vila de Caxambu. Época de grande desenvolvimento foi neste período que foram feitas as principais obras de infraestrutura, como serviços de água e esgoto, aberturas e calçamento de ruas, avenidas e praças, canalização de ribeirões, etc. Finalmente, em 18 de setembro de 1915, Caxambu é elevada à categoria de cidade, abrangendo também, até 1938, a área do atual município de Soledade (www.caxambu.mg.gov.br).

A Família Imperial teve tanta influência na história da cidade que, em 1874, as seis únicas fontes existentes na época levavam nomes de alguns de seus integrantes, dentre eles: D. Pedro, D. Leopoldina, Duque de Saxe, D. Isabel, Conde D’Eu e D. Theresa.

Os principais atrativos turísticos são:

- O Parque das águas, que atualmente conta com 12 fontes de águas minerais, em uma área de $210.000 \mathrm{~m}^{2}$, contando também como uma área de recreação e esportes;

- No interior do Parque está o Balneário Hidroterápico construído no início do século XX em estilo eclético, onde estão disponíveis atualmente as salas de banho e fisioterapia;

- A Igreja de Santa Isabel, hoje tombada IEPHA (Instituto Estadual do Patrimônio Histórico e Artístico), que teve sua construção iniciada em 1868, pela Princesa Isabel, sendo consagrada porém somente no ano de 1897, quando a família imperial já se encontrava no exílio;

- O morro do Caxambu de onde se tem uma bela vista da cidade e do parque, em um de seus lados, e, do outro, a cidade de Baependi. 
O parque e os principais atrativos turísticos estão bem cuidados e preservados na cidade, mas parece haver uma integração entre a "cidade turística" e a "cidade real", dos bairros e da vida na cidade, principalmente no que se refere aos cuidados com os equipamentos urbanos, que estão concentrados na área central.

\section{Cristina}

Em 1774, o padre português José Dutra da Luz, entra na região do Sertão da Pedra Branca, habitada por índios puris, em busca de ouro. No mesmo ano, no dia 13 de maio celebrou a primeira missa. Logo depois transferiu-se para o local da atual sede municipal. Neste local formou-se o povoado do Espírito Santo dos Cunquibus que, em 07 de abril foi elevado a paróquia. Em 19 de junho de 1850, foi criado o município com o território desmembrado de Itajubá, elevando a paróquia à categoria de vila com a denominação atual. Em 15 de julho de 1872, Cristina chegou à categoria de cidade.

Contam os historiadores, que em 1868 a Princesa Isabel e o Conde D'Eu, partiram do Rio de Janeiro, em direção a Caxambu, passando por Cristina. A viagem e a permanência na cidade estão retratadas em quadro de madeira. Também no quadro: a Imperatriz Tereza Cristina e o Dr. Delfim Moreira da Costa Ribeiro; a primeira, que deu nome a esse município e, o segundo que nasceu na data da chegada da Princesa Isabel a Cristina, e mais tarde, tornou-se Presidente da República (www.estradareal.org.br).

Cristina possui 5.481 habitantes residentes na área urbana e 4.845 na área rural (IBGE, Censo 2000). Possui como atrativos turísticos: cachoeiras, monumentos históricos e propriedades rurais, sendo que podem ser citados:

- Cachoeiras da Gruta, do Engenho, e do Lambari (figura 47);

- Mata da Prefeitura, reserva florestal localizada a $1 \mathrm{~km}$ do centro da cidade; 
Os circuitos turísticos como projetos de desenvolvimento para o Alto e Médio Sapucaí

- Pedra Riscada, Trilha do Macaco e do Alemão, locais para prática da caminhada, montanhismo, vôo livre, motocroos e bicicleta;

- Chafariz da Praça, primeiro ponto de canalização de água da cidade no final do século XIX, de 1869;

- Igreja Matriz Divino Espírito Santo, construída em estilo romântico e possui imagens sacras de relevância histórica (figura 48);

- Museu do Trem, que possui locomotiva à vapor Baldinin de 1911, registros fotográficos, acervo da antiga ferrovia Estrada de Ferro Sapucay, objetos e documentos históricos;

- Monumento do Leão, obra do artista plástico português Chico Cascateiro, de 1906.

\section{Maria da Fé}

Procurar o Vale do Sapucaí, alto do vale, o alto dos Campos do Jordão, depois da Serra da Mantiqueira, passando por campos e planaltos cobertos de araucárias, teria sido esse, em largos traços, o itinerário estabelecido pela Bandeira de Antônio Kivet, ainda em 1579. E tal itinerário coincide inteiramente com a região onde hoje está o município de Maria da Fé. Contudo, têm-se efetivas notícias da colonização da região, quando a fazenda Maria da Fé instala, junto à sede de seu estabelecimento, um povoado chamado Campos de Maria da Fé, por volta de 1815. A possível origem do nome do município apresenta duas versões: uma homenageia a mulher empreendedora e enérgica, é ela que dirige a fazenda e seus negócios. A outra é a de que uma jovem bonita, vinda com uma das bandeiras que cruzou aquelas paragens e que se casa com o cacique Jiquitibá (www.estradareal.org.br).

Por especial empenho de seus moradores mais influentes, o povoado passa a distrito e é incorporado ao município de Cristina, em 27 de junho de 1859. Com o 
nome de Maria da Fé, em 30 de agosto de 1911, torna-se município (www.mariadafe.mg.gov.br).

A estação ferroviária, hoje centro cultural, pertencente primeiramente à Estrada de Ferro Sapucay, mais tarde denominada Rede Mineira de Viação e Rede Ferroviária S/A, teve grande influência na formação do município, sendo considerada seu "marco zero".

Atualmente Maria da Fé tem 7.811 habitantes na zona urbana e 6.796 habitantes na zona rural (IBGE, Censo 2000).

Sua economia é baseada na agricultura, com forte destaque para a bataticultura e a fruticultura de clima temperado. A partir de 1990 a cultura da batata, principal fonte de renda e trabalho da região, começa a entrar em decadência devido ao aparecimento de pragas na batata semente, ao corte dos subsídios, ao encarecimento da produção pelo relevo acidentado e pela dificuldade de mecanização e modernização tecnológica o que gerou uma grande perda de competitividade com outras regiões do estado e do país. Diante deste quadro, associado a uma demanda da comunidade para o desenvolvimento de alternativas econômicas, e, aliado ao grande potencial turístico da região, o SEBRAE-MG propôs a implantação de um projeto que estimulasse uma nova alternativa econômica para a cidade através do Turismo no Espaço Rural.

Destacam-se como pontos atrativos da cidade de Maria da Fé: as propriedades rurais; o clima frio, sendo considerada a cidade mais fria do estado; e o artesanato que aparece como alternativa de desenvolvimento no município. Podem ser citados como atrativos:

- As cachoeiras do Zé Braga e Mãe de Ouro no Bairro dos Pintos Negreiros (figura 50); 
- A Fazenda da Epamig onde são realizados experiências agrícolas e cursos para agricultores, com destaque para o desenvolvimento e adaptação das Oliveiras na região; que também dispõe de trilhas ecológicas e para educação ambiental;

- A Igreja Nossa Senhora de Lourdes, construída em 1928, e pintada em 1940 pelos artistas, Pietro e Uderico Gentil, indicados pelo Bispo de Mariana, similar à pintura da capela do Seminário Maior de Mariana. Estas pinturas foram restauradas pelo SEBRAE de Minas Gerais e FAOP, em 2000, sendo que a pintura externa foi restaurada para as cores originais em 2002 (figura 49);

- Centro Cultural situado na antiga estação ferroviária que possui uma locomotiva Raldwin 225 de 1918, desativada;

- Projeto Canteiros da Alma na Praça onde se situa a antiga estação, sendo a única cidade com oliveiras nas praças, vindas de Portugal na década de 40;

- Oficina de Artesanato Gente de Fibra, idealizada pelo artista plástico Domingos Tótora, em um trabalho comunitário que utiliza fibra de bananeira, papel e outros materiais para criar peças utilitárias que hoje são exportadas para diversos países, inclusive a China (figura 51);

- O templo da Sociedade Brasileira de Eubiose.

\section{Itajubá}

Ponto de partida e chegada das viagens realizadas, Itajubá está dentro da área de influência da Estrada Real, mas não faz parte do caminho oficial demarcado pelo Instituto Estrada Real. As cidades de Maria da Fé, Cristina, Pedralva e Dom Viçoso pertencem simultaneamente ao Circuito Turístico Caminhos do Sul de Minas e ao Circuito Estrada Real. Pode-se dizer então que Itajubá está na área de 
influência da Estrada Real podendo absorver o fluxo de turistas oriundo das mesmas, por ser uma cidade pólo desta micro-região. A ocupação do território hoje conhecido como Itajubá é remota, sendo que achados arqueológicos mostram que os índios Puri-Coroados ocuparam a região até o início do século XIX. (GUIMARÃES, SD).

Entre os anos de 1703 e 1705, o sertanista Miguel Garcia de Almeida Cunha, também chamado Miguel Garcia Velho, sertanista e bandeirante paulista de Taubaté, em busca de ouro, descobriu minas novas de Itajybá, atual cidade de Delfim Moreira. Posteriormente, Padre Lourenço da Costa Moreira chega à região e em 1819 transfere sua sede, com o apoio da população local para um lugar menos acidentado à margem direita do Rio Sapucaí, denominada Boa Vista de Itajubá. Considera-se então que Itajubá foi fundada em 19 de março de 1819 com a celebração da primeira missa pelo Padre Lourenço da Costa (GUIMARÃES, 1998).

Em 1878 a cidade de Boa Vista de Itajubá já era uma das mais prósperas e comerciais do Sul de Minas, sendo que muito contribuíram para isto o concurso de imigrantes europeus; portugueses, alemães, espanhóis, franceses e, sobretudo italianos, criando indústrias e incentivando a arte, notadamente a música e o teatro. Em 1891 a construção da Estrada de Ferro Sapucaí (anos mais tarde denominada Rede Sul-Mineira, e posteriormente Rede Mineira de Viação) representou grande incentivo ao desenvolvimento econômico da região (GUIMARÃES, 1998).

O setor de educação hoje considerado de excelente qualidade teve alguns marcos históricos com a criação de escolas primárias e Liceus no final do século XIX. Em 1913 foi inaugurado o ensino superior com a criação do Instituto Eletrotécnico e Mecânico de Itajubá que deu origem à UNIFEI (Universidade Federal de Itajubá). 
Devido a sua posição geográfica privilegiada, próxima a São Paulo, Rio de Janeiro e Belo Horizonte, constituiu-se em um importante centro econômico para o Sul de Minas. A agricultura, comércio e serviços têm uma participação expressiva no quadro econômico do município. O setor industrial é diversificado. A educação de excelência com cinco instituições de ensino superior e baixo índice de analfabetismo colaborou para que a cidade conquistasse em 1998, entre os 853 municípios mineiros, o primeiro lugar no Índice de Desenvolvimento Humano (IDH) medido pela fundação João Pinheiro em trabalho promovido pela ONU (Organização das Nações Unidas) (www.conexaoitajuba.hpg.ig.com.br).

A população urbana é de 76.896 habitantes e a rural 7.149 (www.conexaoitajuba.hpg.ig.com.br, outubro de 2004).

A principal rodovia que cruza a cidade é a BR 459 - Rodovia Juscelino Kubistchek.

Itajubá faz parte do projeto Rota Tecnológica 459 que propõe um processo de desenvolvimento integrado para os municípios abrangidos pela Rodovia BR 459, que liga a Rodovia Fernão Dias à Rodovia Presidente Dutra. Este projeto procura direcionar as ações dos municípios (governo e sociedade organizada) para o aproveitamento de seu potencial educacional de alta qualidade, buscando investimentos em ciência e tecnologia para atrair empreendimentos de base tecnológica, e, preservando as características naturais e culturais da região. (www.itajubá.mg.gov.br).

Em 1993 a comunidade Acadêmica de Itajubá iniciou um projeto denominado Itajubá Tecnópolis que pretendia propor o desenvolvimento do município tendo como partida o investimento em tecnologia em um desenvolvimento integrado. Este projeto 
vem sendo desenvolvido até com a participação de representantes de vários setores da sociedade itajubense (www.mineiros-uai.com.br).

O Plano Diretor de Desenvolvimento de Itajubá, aprovado e publicado em 29 de dezembro de 2003, representa um instrumento importante para o desenvolvimento municipal, abordando em seus objetivos as questões de inclusão e participação social, desenvolvimento sustentável e diretrizes para o projeto tecnópolis.

Itajubá foi considerada a oitava melhor cidade nos indicadores de combate ao analfabetismo segundo dados do Instituto Nacional de Pesquisas Educacionais (Imep) (Jornal Hoje, dia 05 de junho de 2003).

O crescimento da industrialização no município tem sido alvo de programas como o Itajubá Tecnópolis, que representa uma intenção de crescimento para um tipo específico de industrialização, o de base tecnológica.

A atividade agro-pecuária e a silvicultura têm participação pequena no número de empresas do município, sendo que estas atividades estão mais presentes em outros municípios da região. 


\section{Lambari}

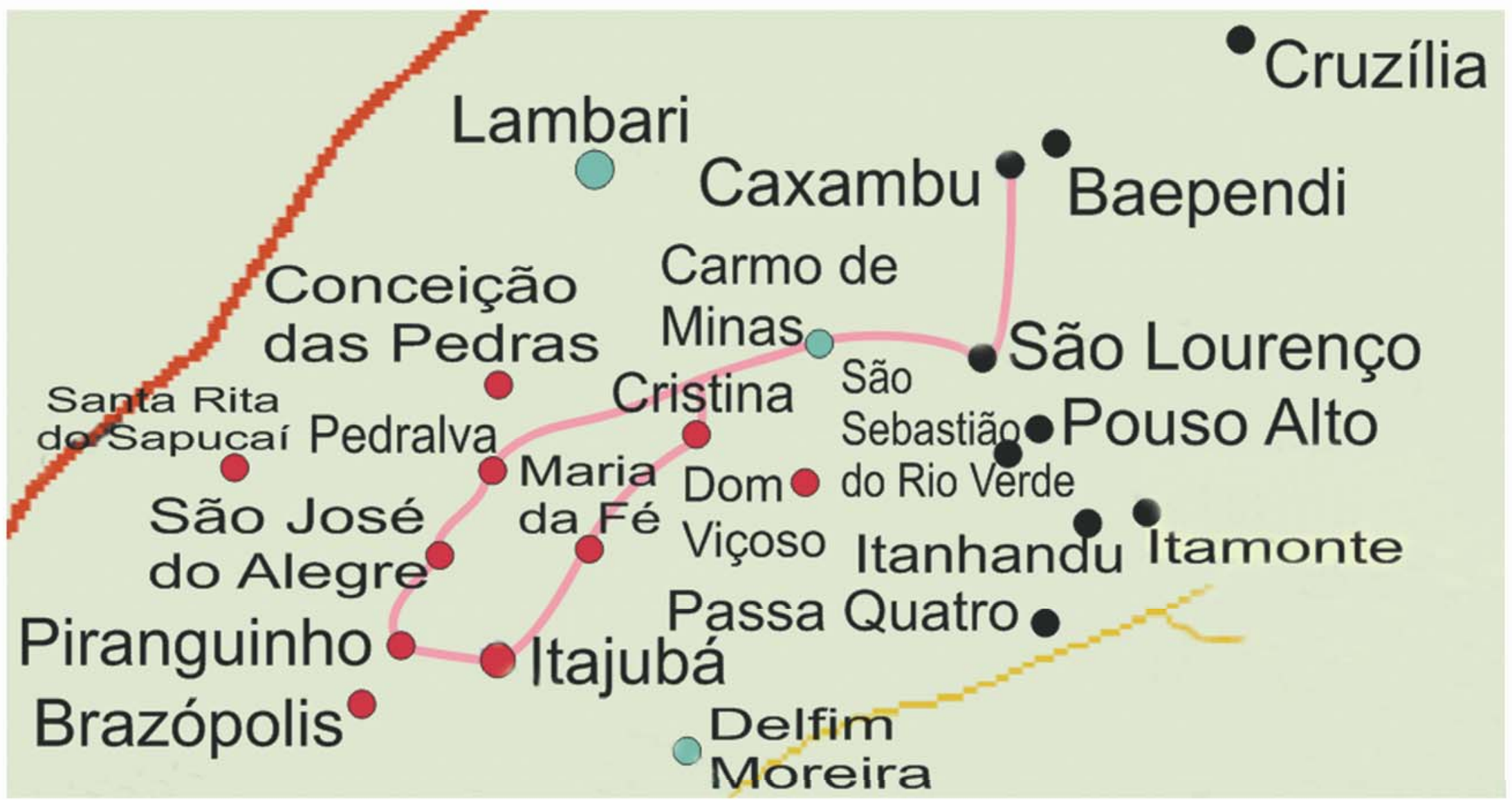

Trajeto de Itajubá a Caxambu 


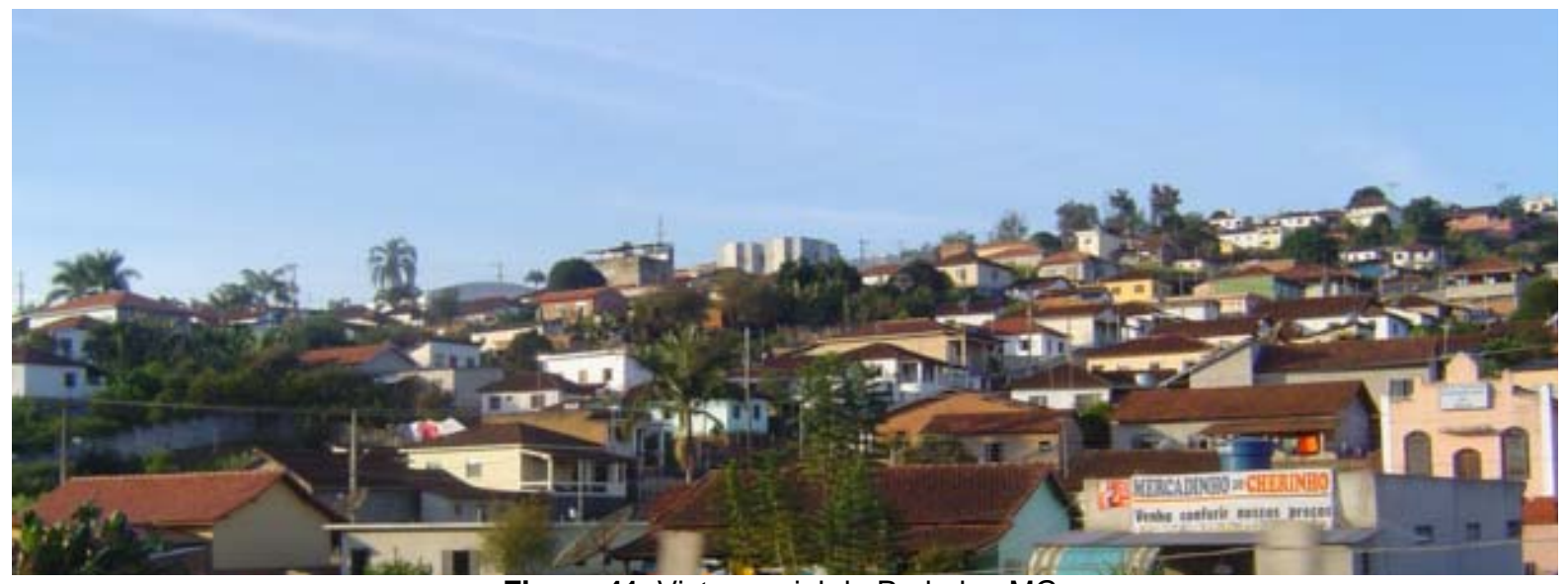

Figura 41: Vista parcial de Pedralva-MG.

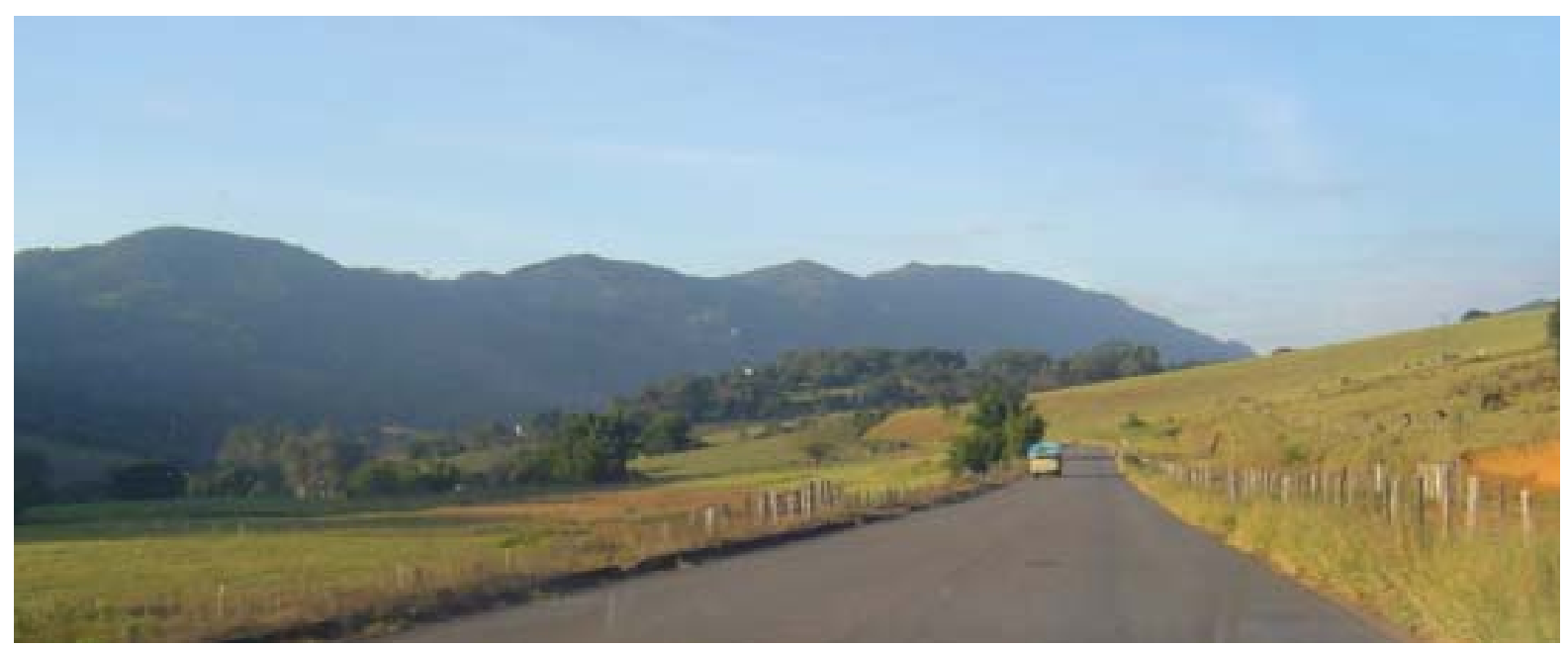

Figura 42: Trecho entre a cidade de Pedralva e São Lourenço.

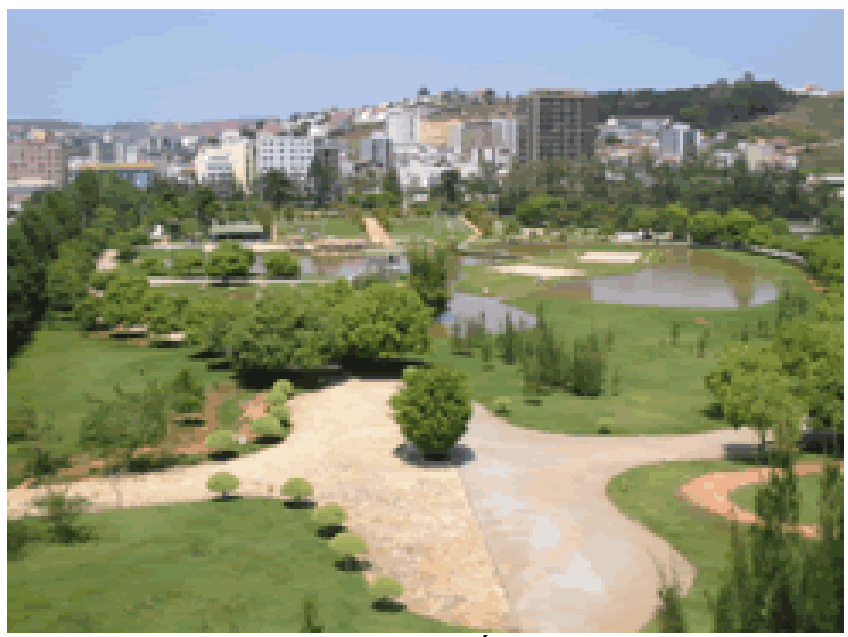

Figura 43: Vista do Parque das Águas em São Lourenço. Fonte: www.saolourenco.mg.gov.br. 


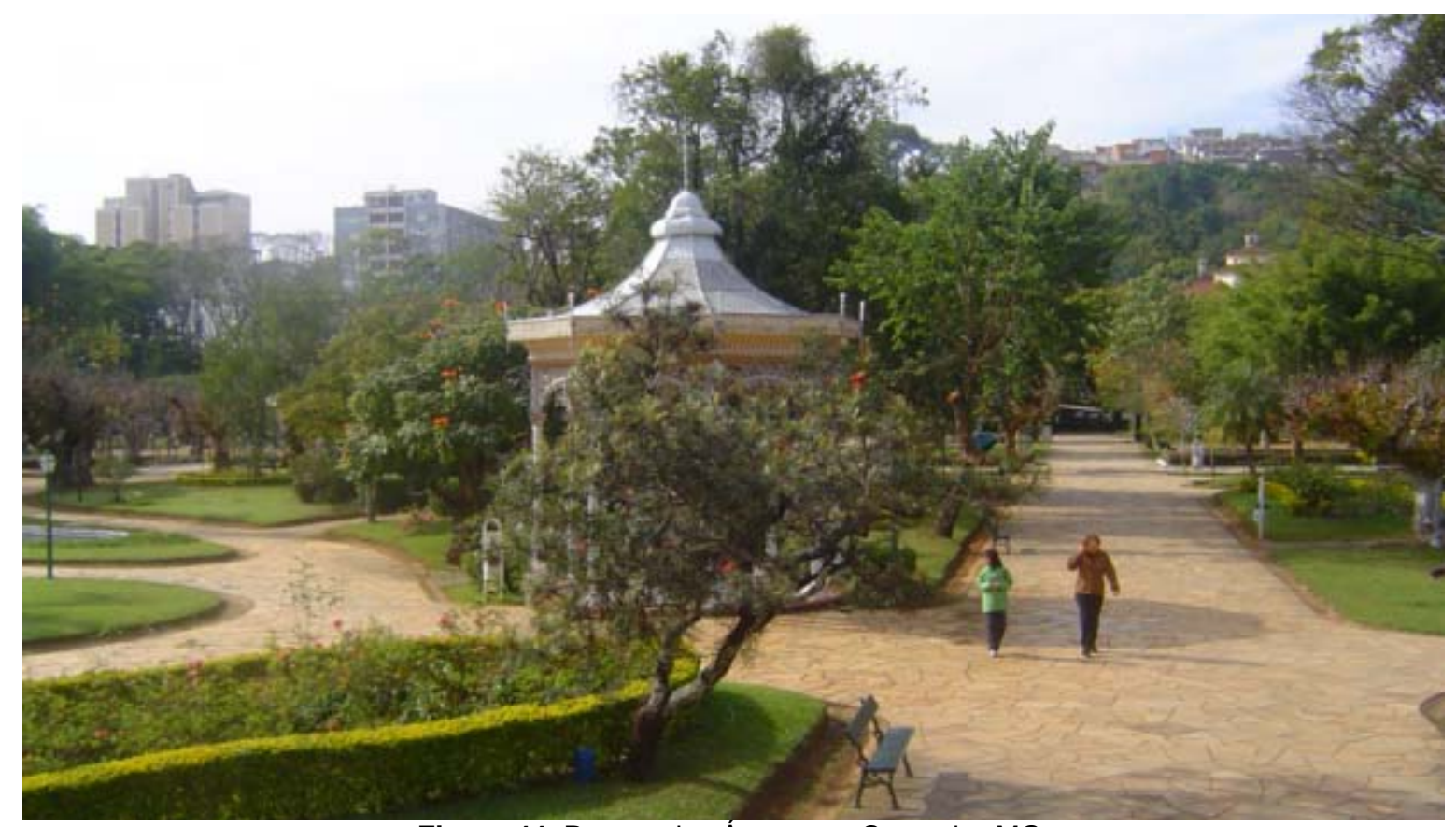

Figura 44: Parque das Águas em Caxambu-MG.

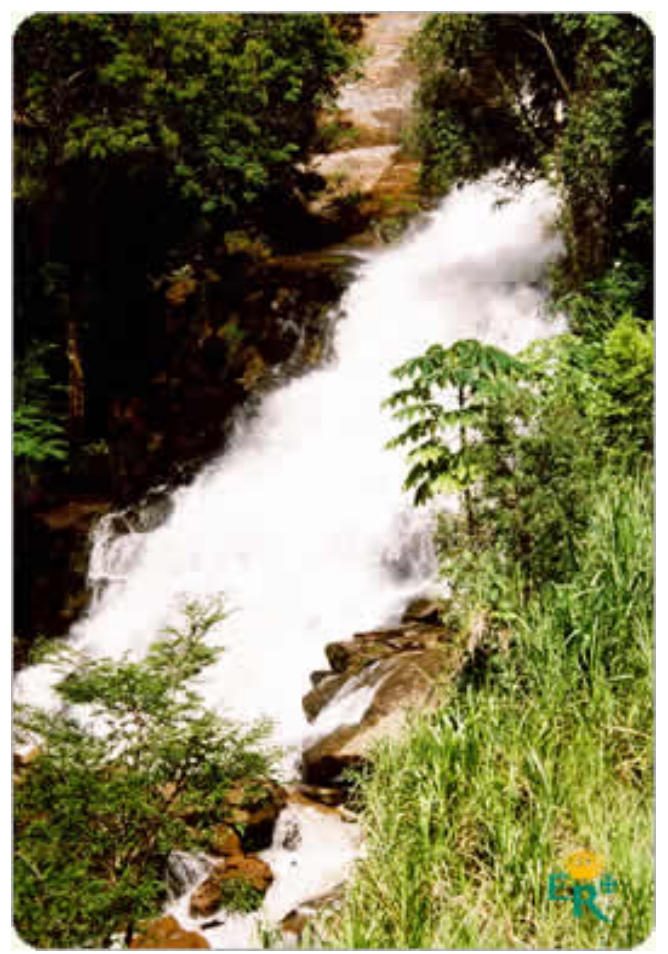

Figura 45: Cachoeira do Lambari em Cristina-MG. Fonte: www.estradareal.org.br. 


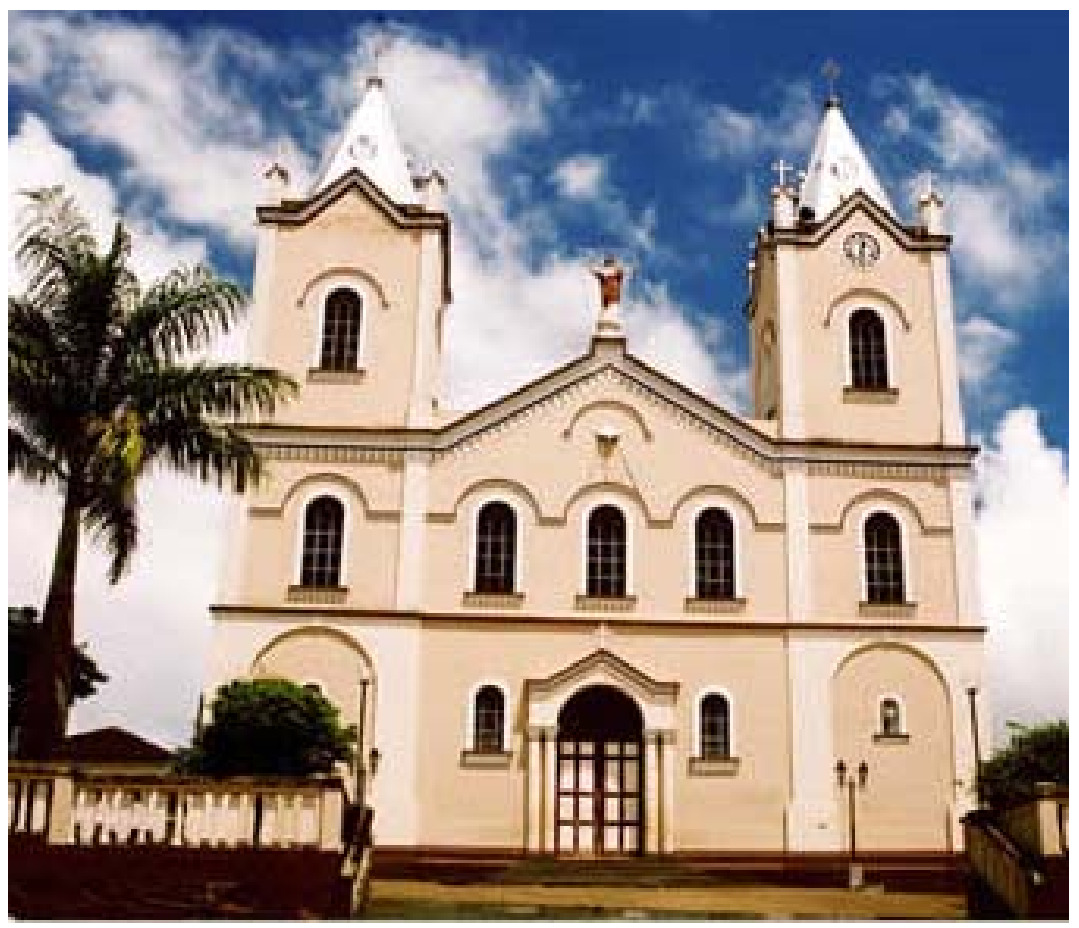

Figura 46: Igreja Divino Espírito Santo em Cristina-MG. Fonte: www.estradareal.org.br.

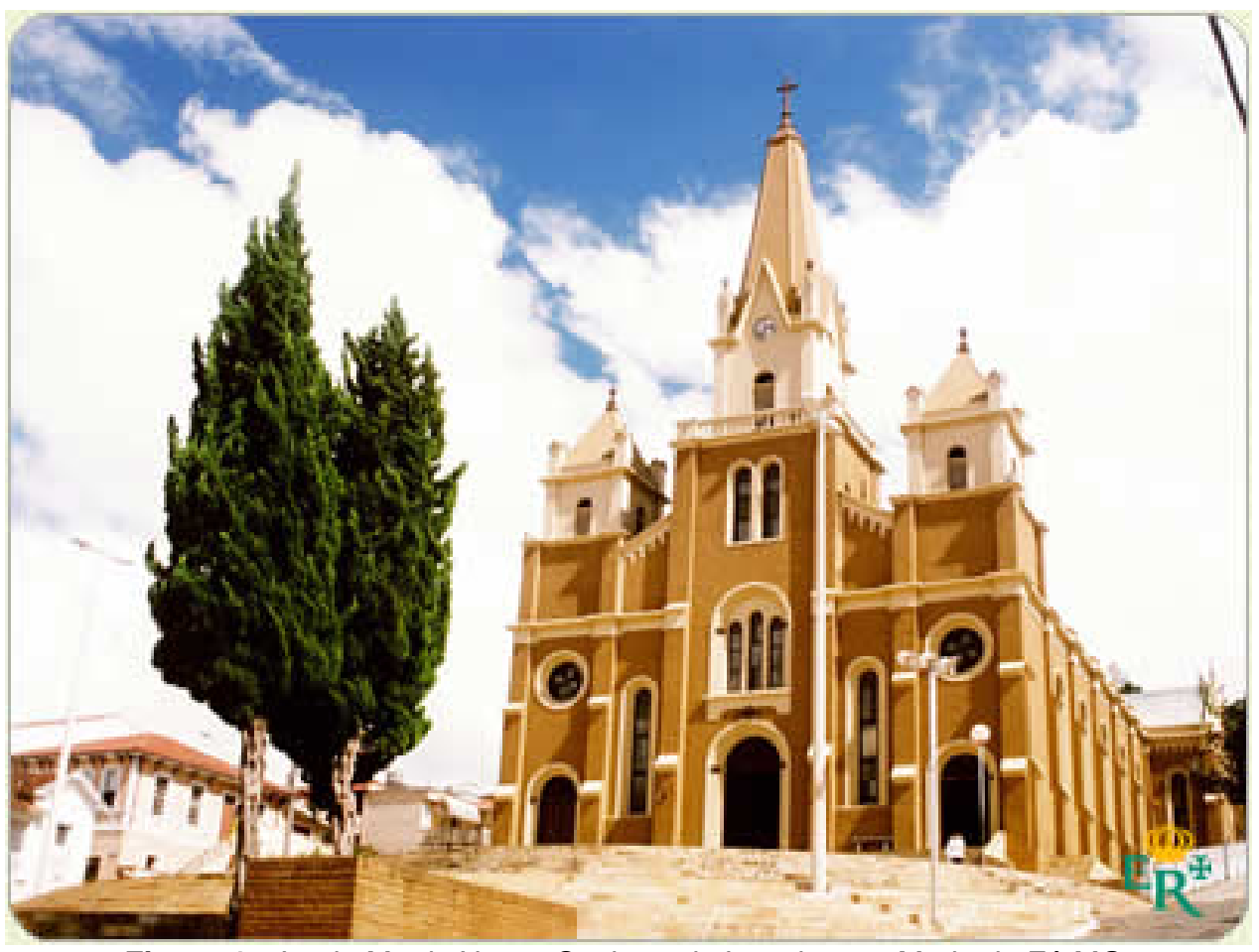

Figura 47: Igreja Matriz Nossa Senhora de Lourdes em Maria da Fé-MG. Fonte: www.estradareal.org.br. 


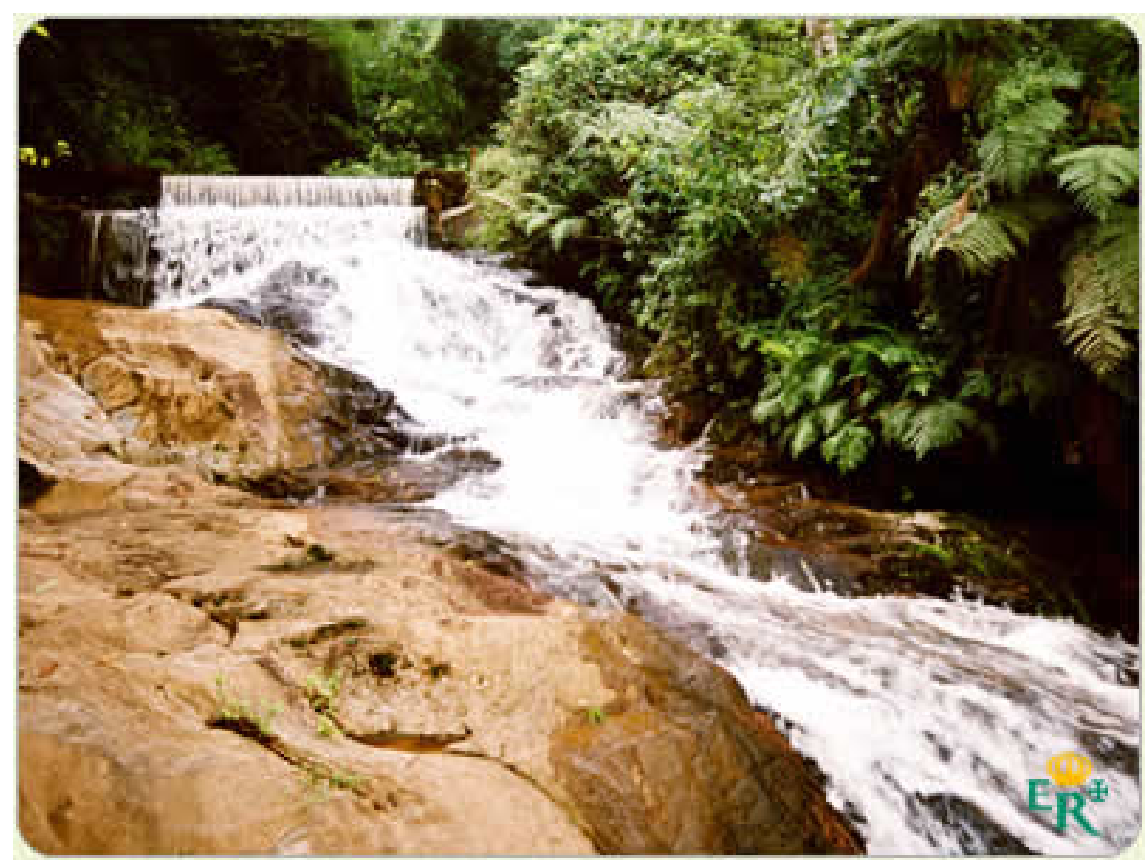

Figura 48: Cachoeira do Zé Braga em Maria da Fé. Fonte: www.estradareal.org.br.

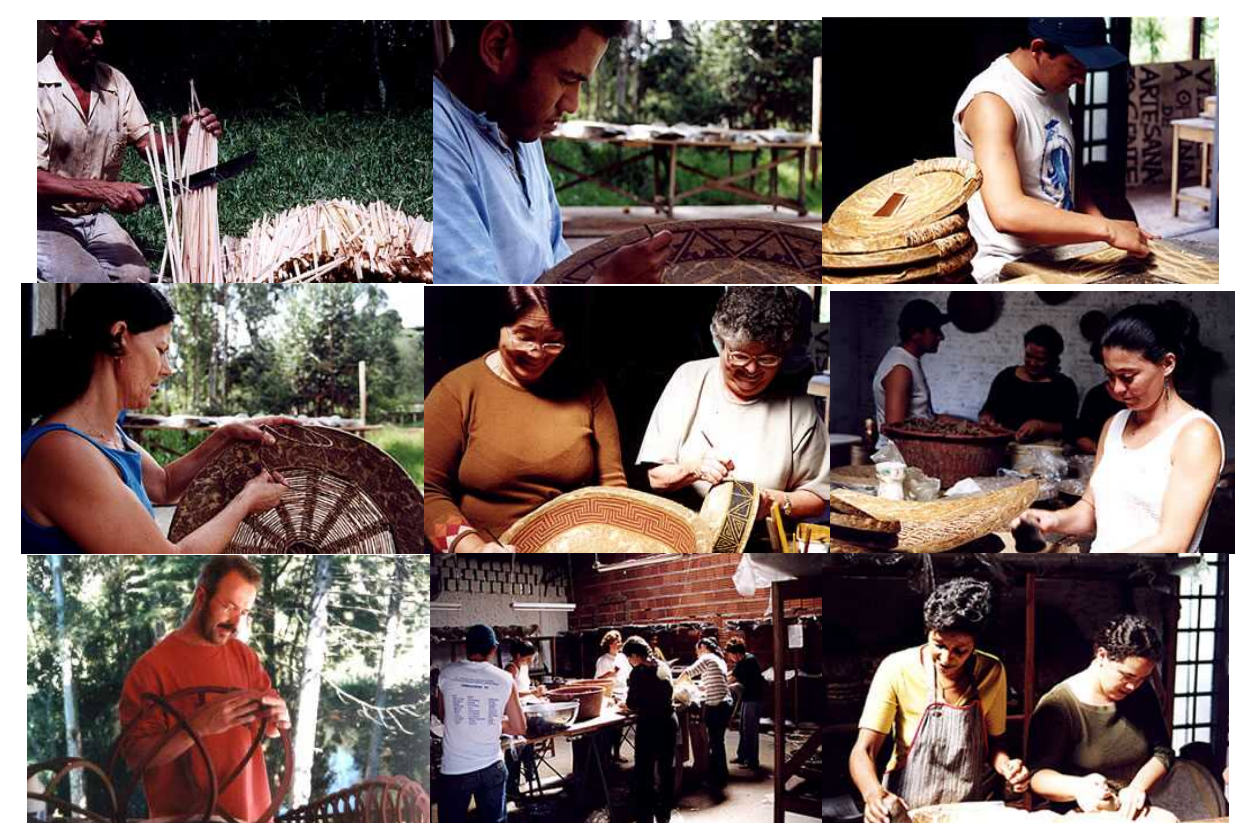

Figura 49: Oficina Gente de Fibra em Maria da Fé. Fonte: www.gentedefibra.com.br. 


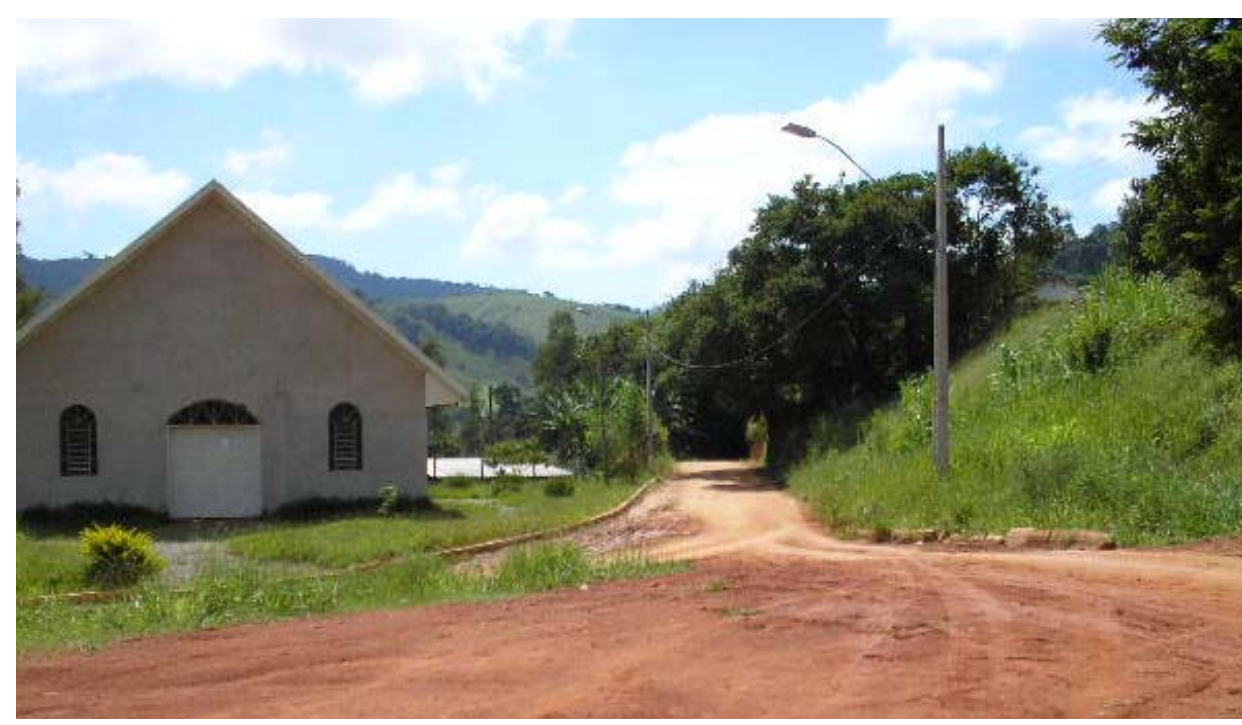

Figura 50: Entrada da Estrada da Serra dos Toledos, onde se localiza a Reserva Biológica da Serra dos Toledos, em Itajubá.

\subsection{3 - Considerações sobre as condições de desenvolvimento dos pontos percorridos no Caminho Velho da Estrada Real}

Os trajetos percorridos revelaram um potencial histórico, paisagístico e natural inegável, no entanto, a organização das atividades turísticas não está bem estruturada na maioria das cidades, sendo que podem ser salientadas algumas dificuldades para o desenvolvimento de tais atividades, quais sejam:

- As vias de acesso em quase todo o trajeto percorrido estão em condições precárias;

- As premissas previstas pelo Instituto Estrada Real pretendem priorizar a visitação de pontos da Estrada Real através do incentivo a se fazer estes percursos de maneira alternativa, como de bicicleta, a pé ou a cavalo, mas, devido à extensão da rota, não se pode suprimir a necessidade de se ter estradas em boas condições de trafego e segurança; 
- Não existem informações ou referências sobre a Rota Estrada Real, tais como placas, sinalizações nas estradas e na área urbana em todas as cidades visitadas, com exceção da Cidade de Caxambu;

- As pessoas contatadas na maior parte das cidades visitadas não estão informadas sobre a Rota Estrada Real;

- A articulação da comunidade com as atividades culturais que poderiam alavancar a atividade turística se faz mais presente apenas nas cidades de Maria da Fé, Cristina, Cunha e nas cidades do Circuito das Águas;

- A sobreposição de circuitos turísticos, principalmente os já consolidados, como o Circuito das Águas, leva a se deixar para segundo Plano as informações e o incentivo às atividades turísticas da Rota Estrada Real;

- O turismo desenvolvido na maioria das cidades está ainda restrito a atividades de recreação de abrangência regional, com exceção da cidade de Cunha e das cidades do Circuito das Águas;

- Alguns circuitos muito recentemente constituídos, que fazem interseções com a Rota Estrada Real, parecem ainda carecer de identidade e de mobilidade viária para que se afirme como circuito de fato. Isto se faz presente principalmente no Circuito Turístico Caminhos do Sul de Minas, onde há uma proximidade espacial entre os municípios, mas parece não haver identidade comum que garanta a obtenção de êxito na venda desta identidade como produto turístico de atração nacional e internacional. Já o Circuito Terras Altas da Mantiqueira apresenta esta identidade comum, porém ainda necessita de investimentos em infra-estrutura para garantir sua sustentabilidade econômica. 
Entre os pontos positivos observados no trajeto percorrido podem ser citados o esforço das comunidades locais na preservação de monumentos históricos e a prática do associativismo como forma de se buscar alternativas para o desenvolvimento local.

Assim considera-se que existe um potencial imenso para o turismo na Rota Estada Real, e que a iniciativa de se resgatar este potencial tem relevância, mas ainda é preciso muito investimento para que tal Rota se consolide como uma atividade que gere renda, melhoria na qualidade de vida, resgate das tradições culturais das comunidades locais abrangidas, assim como conforto e segurança para o público visitante.

\section{4 - Considerações sobre possibilidades de desenvolvimento da atividade turística no Alto e Médio Sapucaí: Circuito Terras Altas da Mantiqueira e Circuito Caminhos do Sul de Minas}

A região do Alto e Médio Sapucaí, representada pelo Circuito Terras Altas da Mantiqueira (Alto Sapucaí) e Circuito Turístico Caminhos do Sul de Minas (Médio Sapucaí) apresentam atrativos suficientes para o desenvolvimento turístico, mas carecem ainda de políticas públicas ou de iniciativa comunitária para desenvolvê-los.

Estes circuitos, por se situarem às margens de circuitos e regiões turísticas já tradicionais como o Circuito das Águas e a cidade de Campos do Jordão em São Paulo, de certa forma concorrem na atração de turistas com estas regiões. Entretanto suas peculiaridades podem ser ressaltadas para que possam atrair turistas com outro perfil. 
Os circuitos turísticos como projetos de desenvolvimento para o Alto e Médio Sapucaí

As figuras abaixo, 53 até 56 , mostram alguns dos atrativos das cidades do Circuito Turístico Caminhos do Sul de Minas:

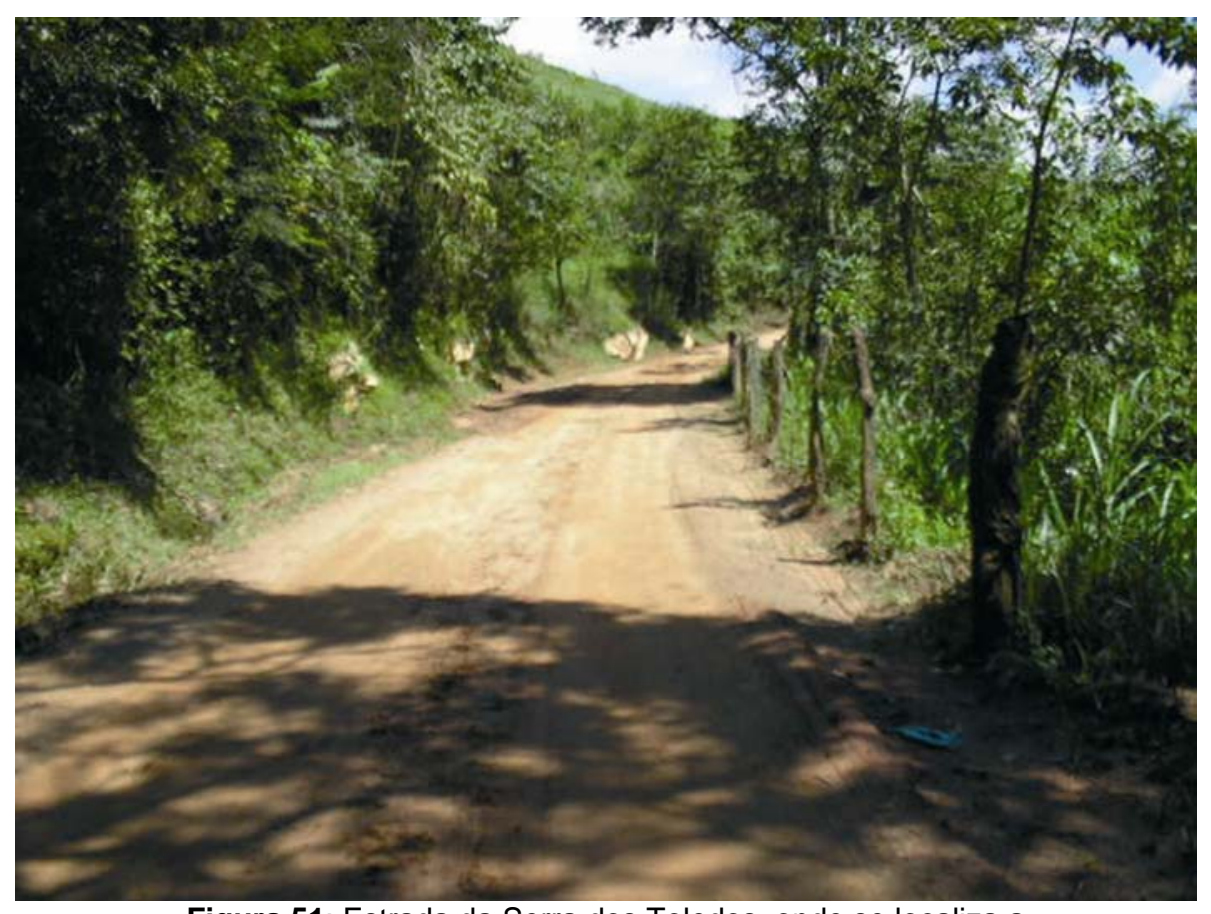

Figura 51: Estrada da Serra dos Toledos, onde se localiza a

Reserva Biológica da Serra dos Toledos, em Itajubá. Fonte: Helena M. Faria, 2006.

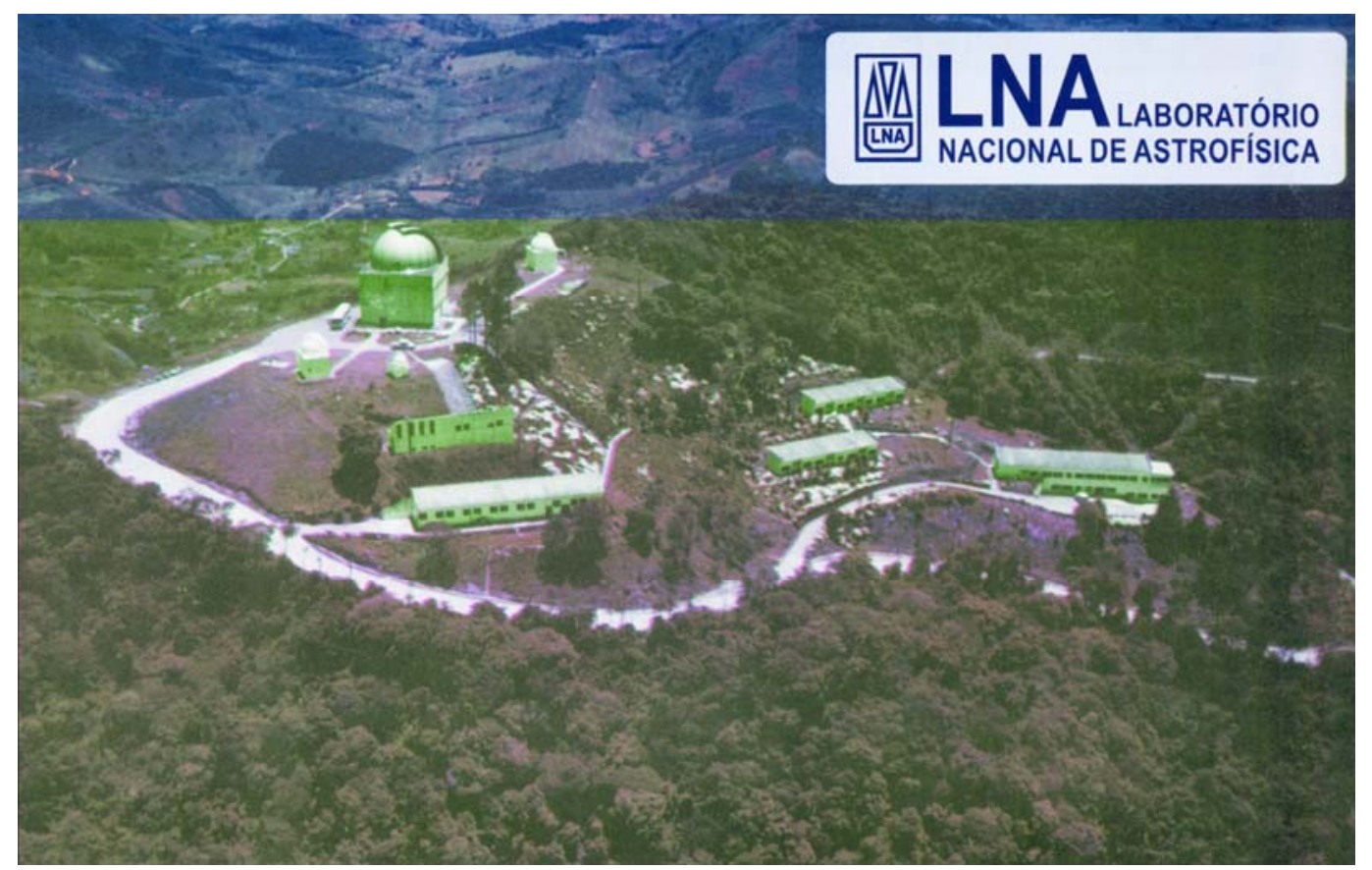

Figura 52: Observatório Nacional de Astrofísica em Brasópolis. Fonte: Panfleto do Laboratório Nacional de Astrofísica (LNA), 2003. 


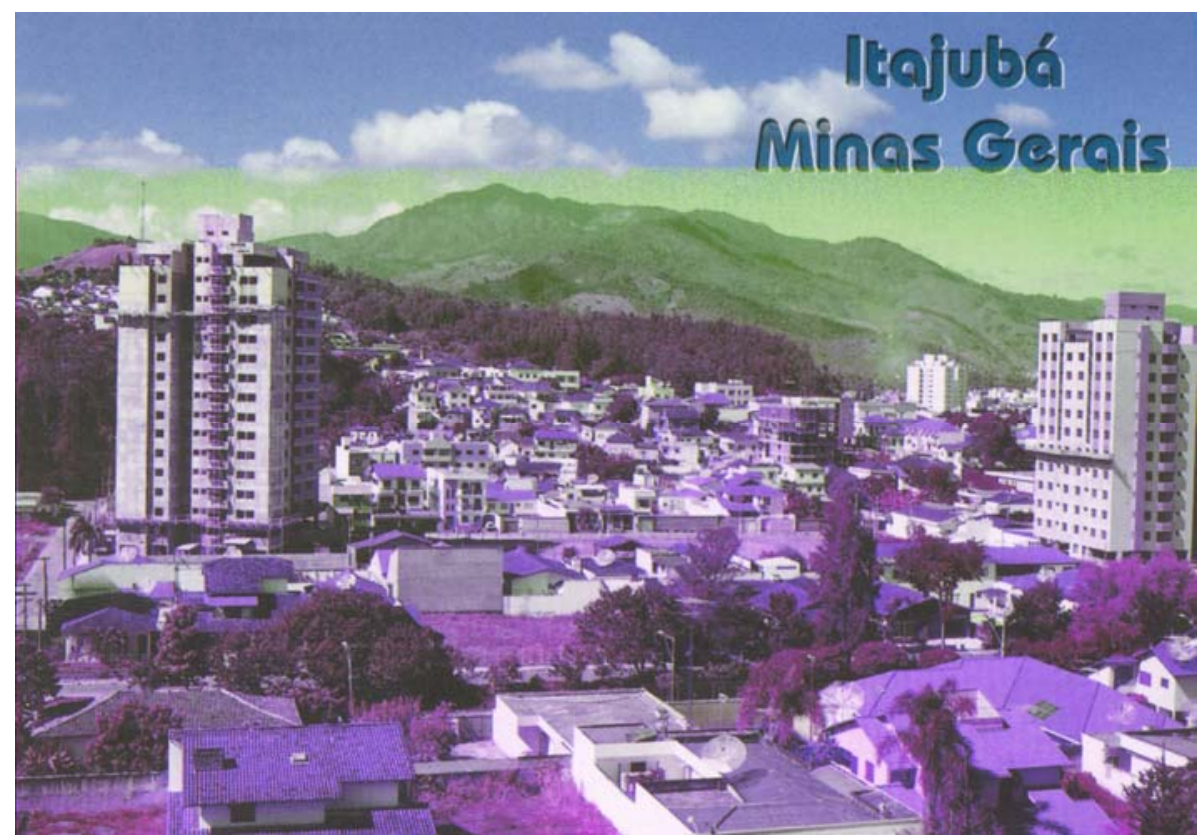

Figura 53: Vista de Itajubá. Fonte: Cartão Postal 2005.

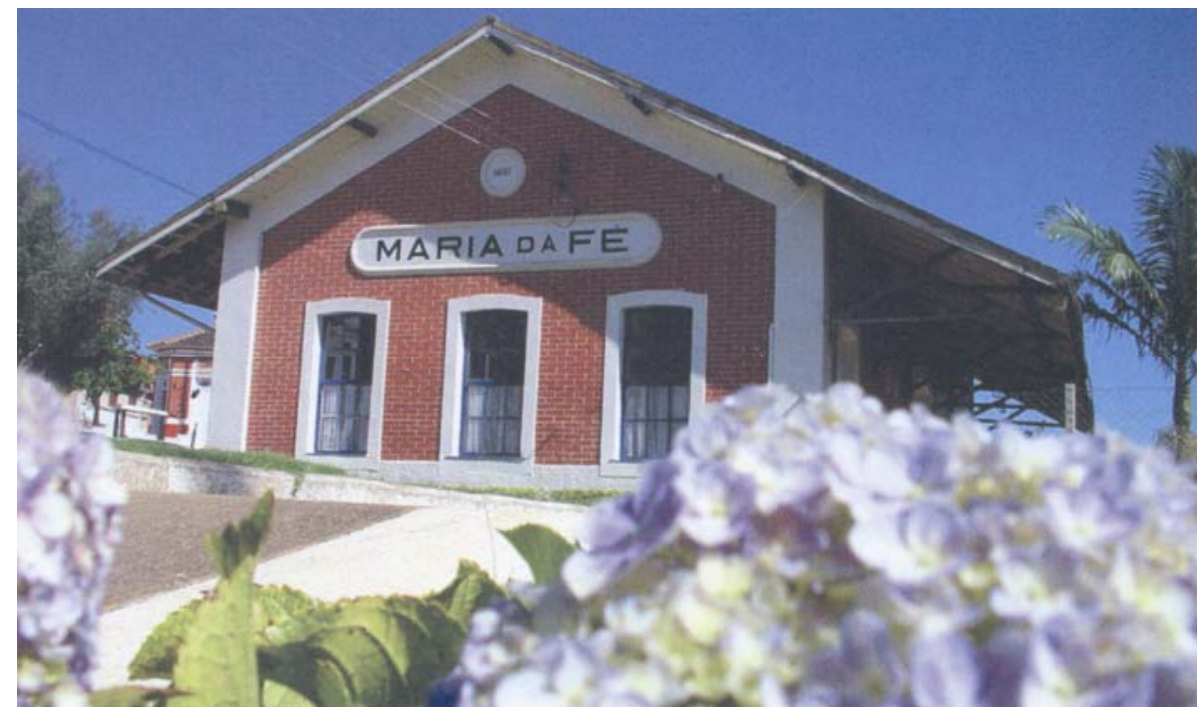

Figura 54: Antiga Estação Ferroviária de Maria da Fé-MG. Fonte: Cartão Postal, 2005.

Alguns atrativos do Circuito Terras Altas da Mantiqueira são mostrados abaixo, nas figuras 57 até 61: 


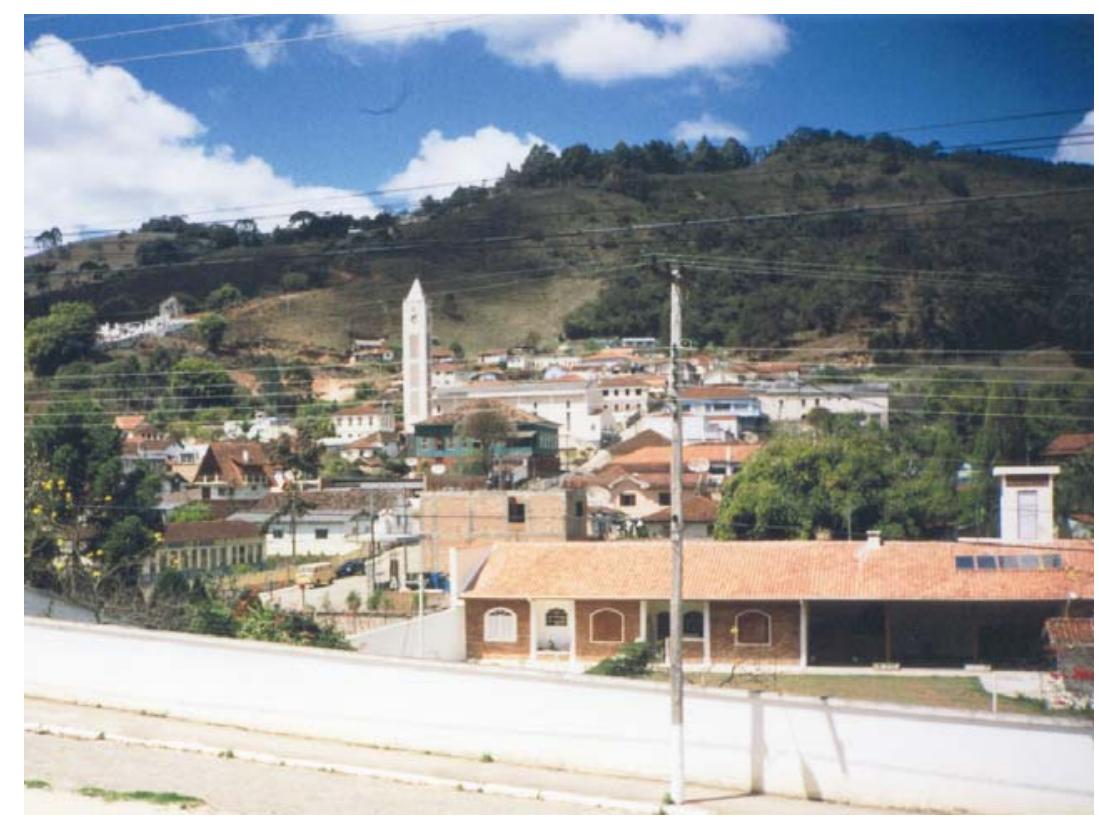

Figura 55: Vista de Delfim Moreira. Foto: Izabel M. Faria, 2007.

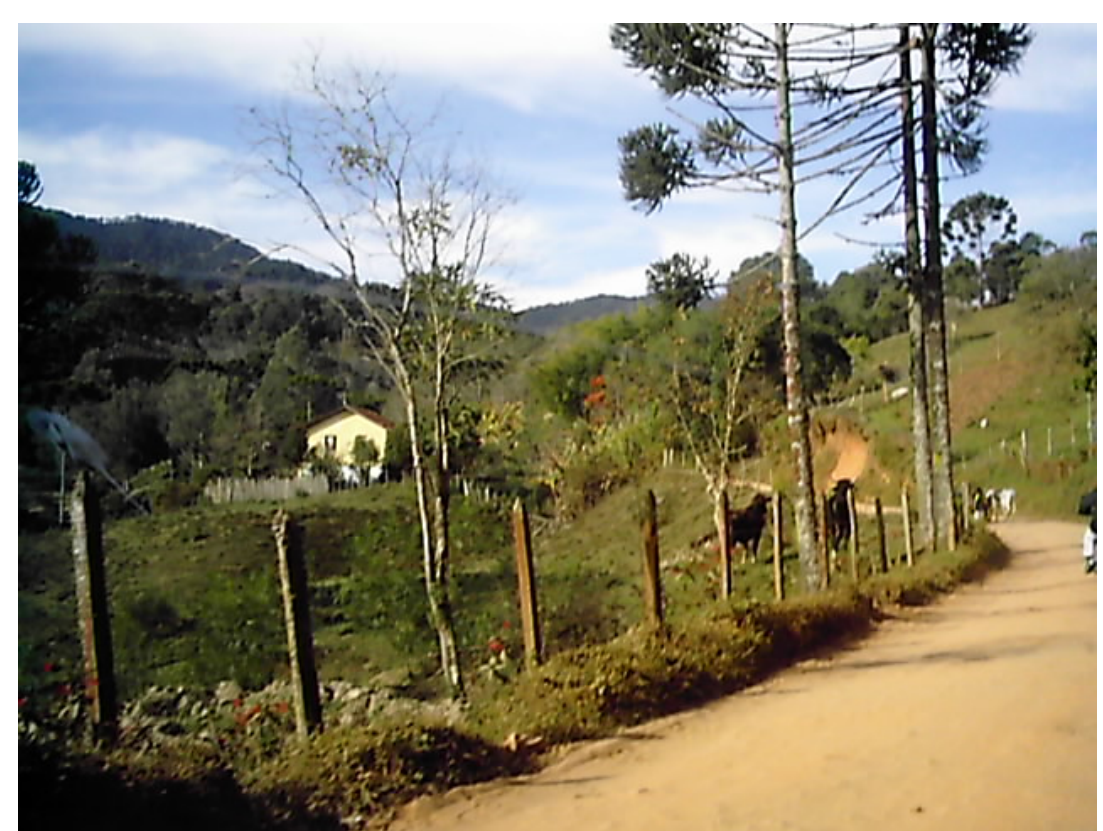

Figura 56: Vista de área rural em Delfim Moreira. Foto: Izabel M. Faria, 2007. 


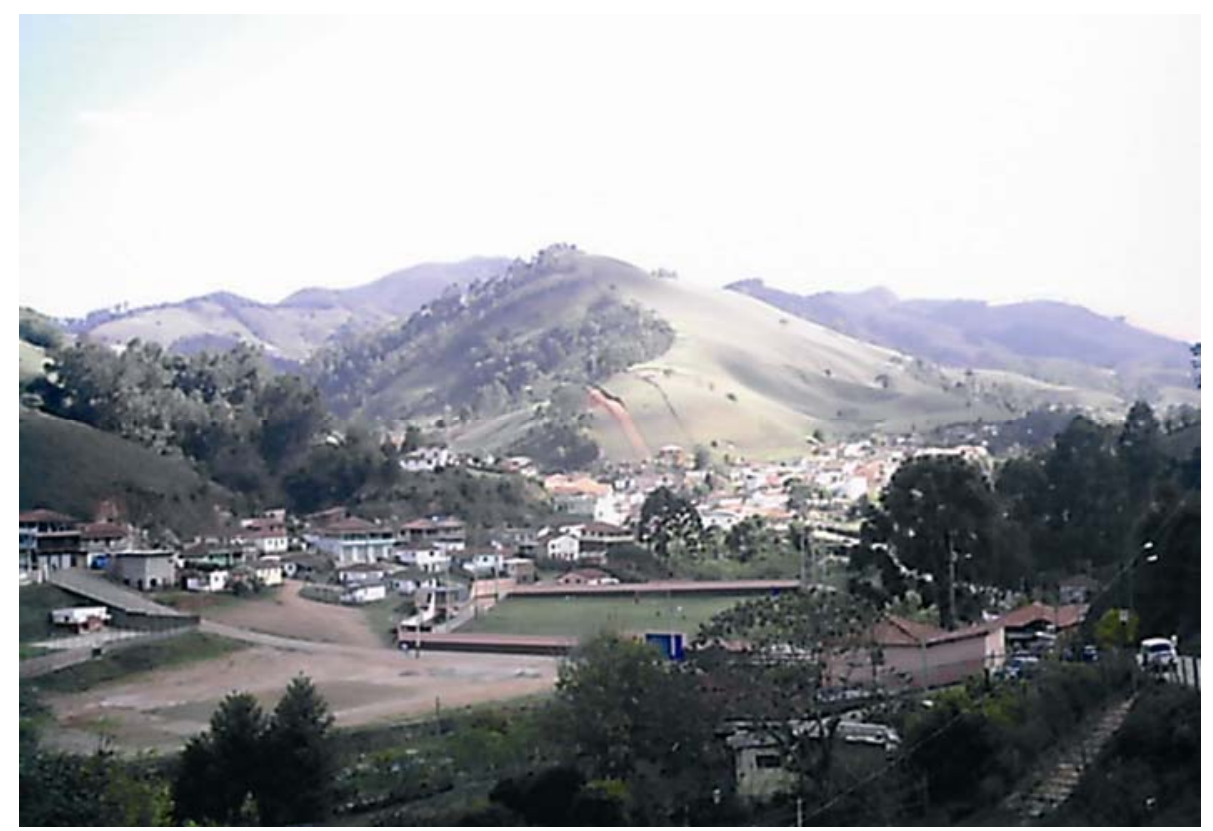

Figura 57: Vista da cidade de Marmelópolis.

Foto: Henrique A. M. Faria, 2007.

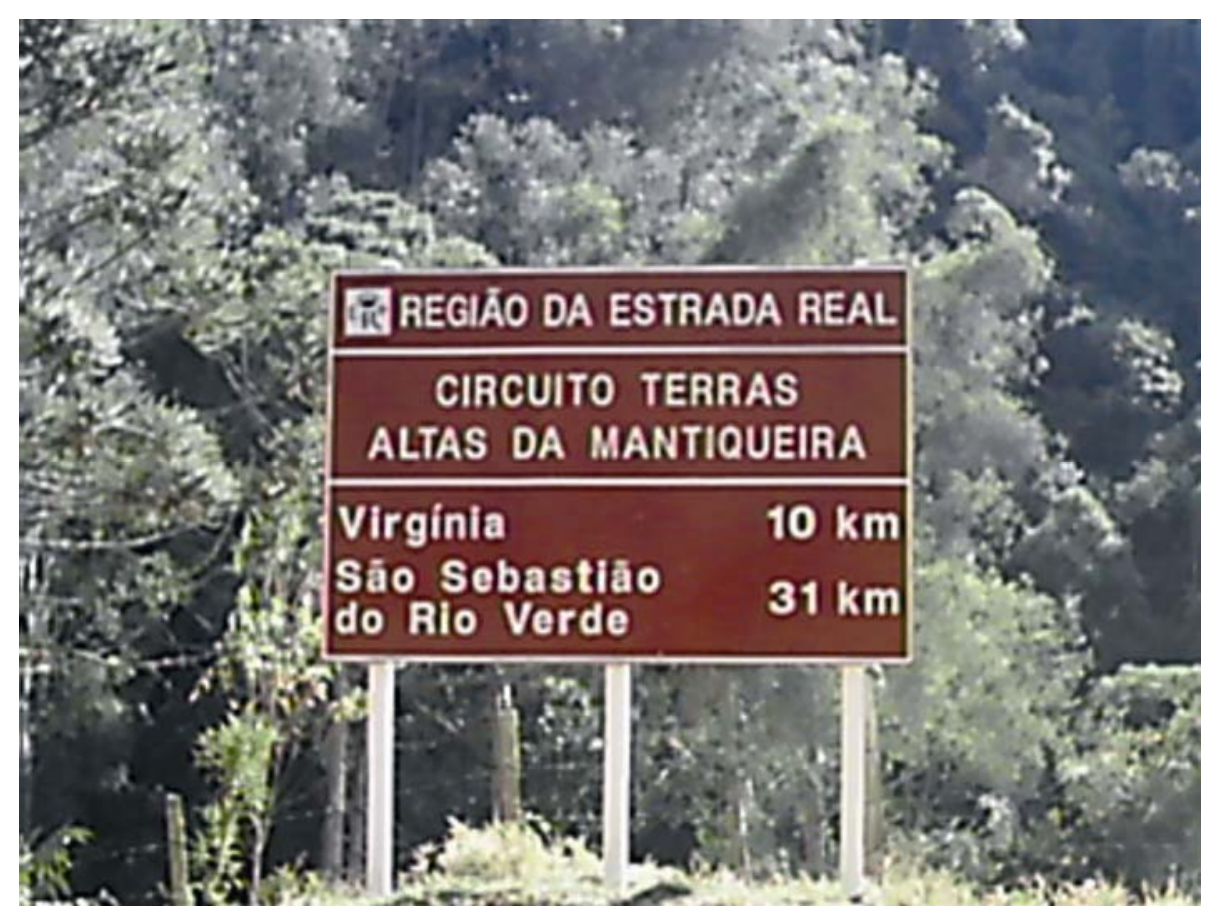

Figura 58: Placa do Circuito Estrada Real na cidade de Virgínia.

Foto: Elaine C. Pereira, 2007. 


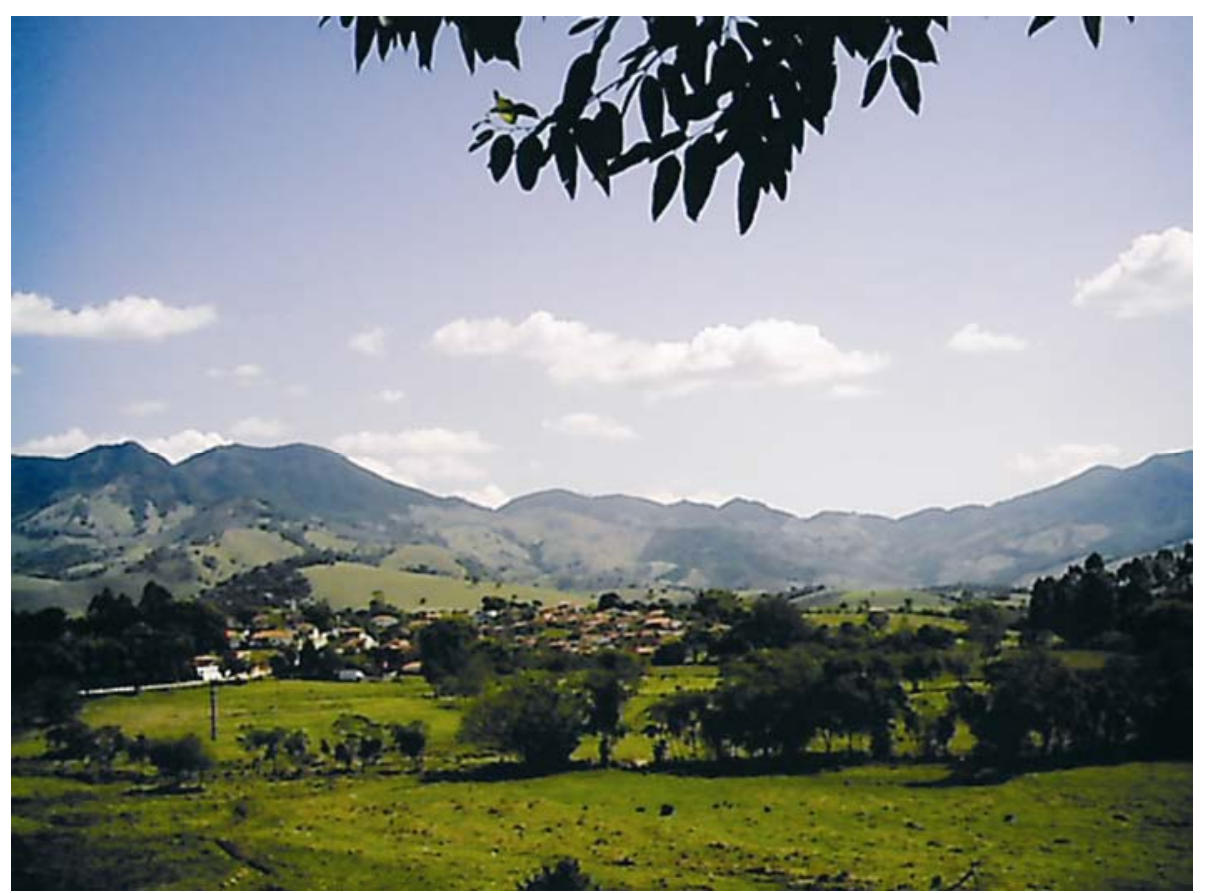

Figura 59: Vista da cidade de Virgínia. Foto: Elaine C. Pereira, 2007.

A Rota Estrada Real que coincide com estes dois circuitos é um fator de atração potencial, mas ainda carece de estruturação nesta região.

A cidade de Itajubá figura como pólo regional econômico para a micro-região a que pertence. Ao mesmo tempo em que apresenta em seu planejamento o objetivo de se tornar um pólo Tecnológico, a atividade industrial não parece ser suficiente para garantir seu desenvolvimento, sendo necessário buscar atividades alternativas. Apresenta pouca área física para expansão urbana, e isto se torna um empecilho ao desenvolvimento industrial tradicional. O clima montanhoso também restringe algumas atividades e outras acabam sendo desenvolvidas inadequadamente. Entretanto o que pode restringir alguns tipos de atividade favorece outras, sendo assim o turismo tem se apresentado como uma atividade que pode ser melhor aproveitada nesta região.

O turismo apresenta potencial de desenvolvimento com respeito à questão ambiental na região estudada, mas deve ser bem estruturado e seu planejamento 
deve prever investimentos e ações a longo prazo. Nesse sentido algumas ações podem ser destacadas como prioritárias:

- A pesquisa sobre a percepção e a opinião da população sobre seu patrimônio cultural e natural e a partir daí ações para o envolvimento da comunidade;

- Melhoria do estado de conservação do patrimônio natural;

- Melhoria dos equipamentos urbanos disponíveis na região;

- Melhoria da infra-estrutura viária; etc.

- Melhoria na comunicação visual e na propaganda dos circuitos;

- Melhor integração com os outros circuitos - Estrada Real, Circuitos das Águas. 
PARTE 3

CENÁRIOS AMBIENTAIS PARA O ALTO E MÉDIO SAPUCAÍ 


\title{
CAPÍTULO 5
}

\section{CENÁRIOS DO PLANEJAMENTO AMBIENTAL NA BACIA HIDROGRÁFICA DO SAPUCAÍ}

\author{
Quadro nenhum está acabado, \\ disse certo pintor; \\ se pode sem fim continuá-lo, \\ primeiro, ao além de outro quadro \\ que, feito a partir de tal forma, \\ tem na tela, oculta, uma porta que dá a um corredor, \\ que leva a outra e a muitas outras. \\ João Cabral de Melo Neto.
}

Percebe-se algumas diferenças entre os municípios do Alto e do Médio Sapucaí. Enquanto os integrantes do Alto Sapucaí têm suas atividades e populações com características rurais, apresenta municípios pequenos e têm suas áreas preservadas, pelo menos legalmente, pela APA da Serra da Mantiqueira, os integrantes do Médio Sapucaí apresentam população urbana em sua maioria, economia industrial, ainda que a agricultura seja importante, e problemas de conservação ambiental principalmente às margens do Rio Sapucaí.

Tendo em vista a caracterização apresentada nos capítulos 3 e 4 o planejamento ambiental na Região da Bacia Hidrográfica do Sapucaí em suas porções Alta e Média deve seguir algumas premissas propostas como alternativa para seu desenvolvimento aliado a conservação e preservação ambiental, quais sejam:

- Melhoramento da Gestão Participativa na APA da Serra da Mantiqueira, com recuperação de áreas desmatadas e programas de desenvolvimento, que 
incluam a melhoria de renda, educação e saúde, tendo em vista que os municípios do Alto Sapucaí apresentam menor Índice de Desenvolvimento Humano do que os do Médio Sapucaí;

- Aperfeiçoamento das atividades turísticas na APA da Serra da Mantiqueira, que pode ser uma alternativa de desenvolvimento econômico menos impactante do que a agropecuária e a industrialização, se for bem direcionada;

- Programas de conservação ambiental ao longo do Rio Sapucaí e seus afluentes;

- Criação de uma APA linear ao longo do Médio Sapucaí, que poderia ajudar em sua conservação;

- Tratamento do esgoto doméstico ao longo da Bacia do Sapucaí, com especial atenção para as áreas mais urbanizadas (Pouso Alegre, Itajubá e Santa Rita do Sapucaí);

- Cuidados com a prevenção da contaminação ambiental dos rios da bacia em função das atividades agrícolas e industriais.

- Melhoria na rede viária que é essencial para o desenvolvimento econômico, principalmente industrial e turístico.

\section{1 - Integração do Alto e Médio Sapucaí através do planejamento e da gestão ambiental}

Vale e montanha são aqueles lugares destinados à preservação ambiental, em todos os princípios dos diversos teóricos e planejadores ambientais. A sociedade humana não tem encontrado uma forma de ocupar estes espaços de maneira que estes se conservem. 
A região estudada, entre o vale e a montanha é tratada por políticas ambientais de maneira dicotômica. Uma das soluções apontadas é a criação de corredores ecológicos, apontados por estudiosos como uma saída para manutenção do equilíbrio ambiental.

Sob o aspecto econômico há a tendência de se privilegiar historicamente o desenvolvimento do vale e um esvaziamento da montanha. Isto gera de certa forma preservação na montanha, ainda que não totalmente eficaz, e esvaziamento social e econômico na mesma. O vale é a região onde ocorre o desenvolvimento econômico, mas não a preservação ambiental, ocorrendo enchentes, poluição, degradação da saúde e baixa qualidade de vida. Isto é observado na região da APA da Serra da Mantiqueira em sua intersecção com a Bacia Hidrográfica do Sapucaí (em sua porção Alta) e na região do Médio Sapucaí (vale).

Para a região estudada um caminho possível seria uma nova forma de se pensar a relação homem-ambiente no planejamento ambiental, promovendo uma situação onde houvesse incentivo à promoção social na montanha (APA da Serra da Mantiqueira) aliada a conservação ambiental, e, uma alavancagem da preservação ambiental no vale, que pode ter como fator coadjuvante o desenvolvimento turístico e também o da agricultura orgânica e das indústrias da base tecnológica. Para que isto ocorra são propostas algumas ações:

- Recuperação das Áreas de Preservação Permanente ao longo ao longo do Médio Sapucaí;

- Programas de incentivo ao desenvolvimento social e econômico na APA da Serra da Mantiqueira;

- A integração destas duas áreas através da redefinição da infra-estrutura viária aproveitando os circuitos turísticos e valorizando as características 
paisagísticas rurais e urbanas. Isto pode se realizado com a valorização da Br.459, Rodovia Juscelino Kubitschek.

- Desenvolvimento de programas de incentivo a valorização de expressões artísticas e culturais;

- Fortalecimento do planejamento e da Gestão Ambiental nos municípios, elementos fundamentais para os objetivos do planejamento ambiental;

- Incentivo a programas de educação ambiental em todos os níveis de escolaridade da região.

\section{2 - Criação de cenários ambientais para o Alto e Médio Sapucaí.}

Diante de tudo que foi mostrado e discutido neste trabalho, percebe-se que apesar de todo potencial apresentado para a sustentabilidade a região estudada não se reconhece como tal. Faz-se necessário um resgate da identidade mais profunda desta região e a reformulação de conceitos com a valorização da cultura e das riquezas naturais inerentes a este território. Sendo assim o planejamento ambiental é um instrumento primordial para o cumprimento desta tarefa. Sem planejamento não há articulação e reformulação de conceitos. Cabe ainda ressaltar que as características do planejamento ambiental devem ser as mais democráticas possíveis para que seus objetivos se cumpram.

A iniciativa para o planejamento ambiental deve mobilizar os mais diversos setores sociais da região do Alto e Médio Sapucaí. O que se observou foi que existem ações isoladas para a melhoria das condições de conservação ambiental e do desenvolvimento das atividades de turismo e da indústria de base tecnológica. $\mathrm{O}$ que não acontece ainda na região estudada é uma articulação entre estas iniciativas e ações. Esta articulação é o principal fator para que ocorra a sustentabilidade. Os 
cenários apresentados a seguir trazem formulações para o desenvolvimento destas três atividades centrais: a conservação ambiental, o turismo e a indústria de base tecnológica, que deverão convergir para um cenário ideal que os agregue: o do desenvolvimento sustentável.

Em termos de gerenciamento ambiental a proposta é que o planejamento ambiental possa ser gerenciado pelo próprio Comitê de Bacia Hidrográfica do Rio Sapucaí, por ser uma entidade representativa e democrática; por uma Organização Não Governamental subsidiada pelo Estado; ou ainda pela Associação dos Municípios integrantes da bacia e outras entidades que se organizariam em um Fórum permanente de pesquisa, discussões e deliberações. A entidade gestora poderá também obter recursos através de fundos destinados ao meio ambiente e à cultura, nacionais e/ou internacionais. Um exemplo desta experiência de gerenciamento proposta é a execução do plano de ação para o Corredor Ecológico da Mantiqueira que está com suas atividades em curso.

O processo de planejamento deverá contar com uma equipe interdisciplinar formada por profissionais das universidades da região e também, se necessário, poderá contar com o apoio de profissionais de outras regiões. A participação comunitária pode ser incentivada através da realização de reuniões periódicas que atualizarão os representantes da comunidade a respeito de estudos realizados. Esta participação de todos envolvidos deverá ser consultiva e deliberativa.

As observações a seguir ilustram os três cenários propostos para o planejamento ambiental na Bacia Hidrográfica do Sapucaí em sua porção Alta e Média, e o cenário de integração entendido como cenário de desenvolvimento sustentável. A figura abaixo ilustra como pode ser estruturado o processo de planejamento na Bacia Hidrográfica do Alto e Médio Sapucaí. 
Comitê de Bacia Hidrográfica do Sapucaí, ONG X ou Fórum de Associação de Municípios e outras entidades.

\section{Processo de Planejamento:}

\section{Cenários Ambientais para o Alto Sapucaí}

\section{Tempo de realização dos Cenários Propostos}
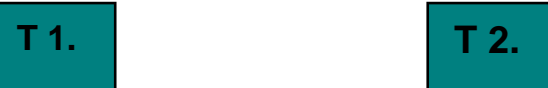

T 3.

- Valorização dos Recursos Naturais -Recuperação de áreas degradadas - Incentivo a conservação nas APAs. - Pesquisa científica sobre a biodiversidade

- Valorização do patrimônio cultural, histórico e artístico; - Fortalecimento dos Circuitos

Turístico - Melhoria da infra-estrutura viária e urbana.

- Valorização do patrimônio cultural, histórico e artístico; - Fortalecimento dos Circuitos Turístico - Melhoria da infra-estrutura viária e urbana.
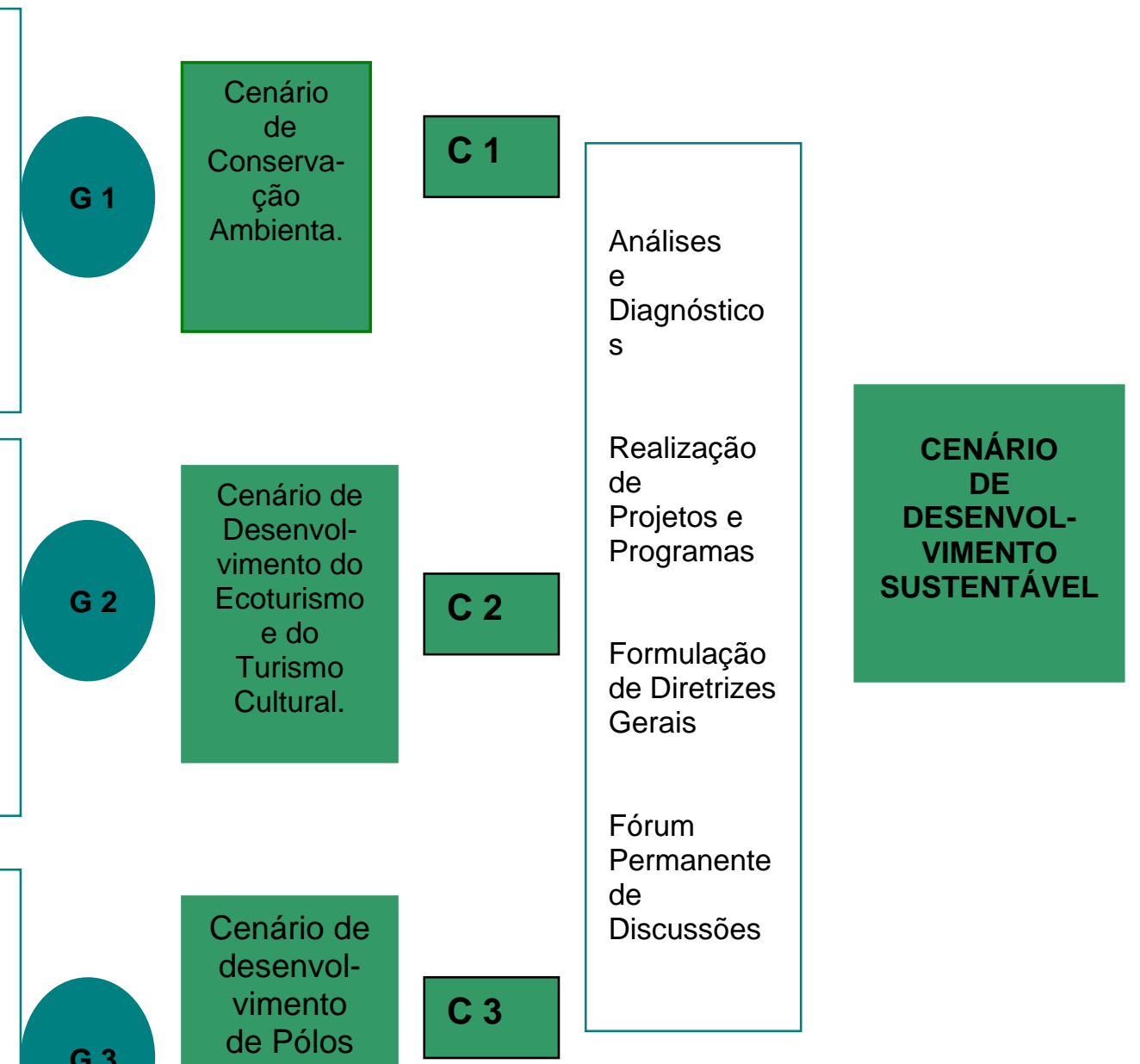

Legenda: $\mathrm{C}=$ Cenários $\mathrm{G}=$ Grupos de Trabalho

Figura 60: Diagrama de Criação de Cenários Ambientais para a Sustentabilidade na Bacia Hidrográfica do Sapucaí. Referência: Franco, 2001, p.236. 


\subsection{1 - Cenário de conservação ambiental para o Alto e Médio Sapucaí}

Neste trabalho percebeu-se que a região estudada a despeito de ações já existentes com objetivos de conservação ambiental tais como a existência da APA da Serra da Mantiqueira e do Corredor Ecológico da Serra da Mantiqueira ainda apresenta riscos de degradação ambiental especialmente na porção média da bacia hidrográfica.

O cenário proposto prevê a participação de entidades como a AMASP (Associação dos Municípios do Alto Sapucaí) e da AMMS (Associação dos Municípios do Médio Sapucaí). A instituição integradora do plano seria o Comitê de Bacia Hidrográfica do Sapucaí ou uma entidade como uma organização não governamental.

Neste caso os objetivos básicos seriam a conservação, a preservação e a recuperação ambiental. As ações propostas seriam ordenadas da seguinte forma:

- Recuperação de áreas degradadas, especialmente em áreas de preservação permanente (APPs) ao longo das margens dos rios integrantes da bacia e nas áreas de encosta com plantio de espécies nativas;

- Fortalecimento do Gerenciamento da APA da Serra da Mantiqueira com a integração de municípios e gestores do IBAMA, bem como outras entidades como as universidades, centros de pesquisa e até mesmo empreendedores da área de biotecnologia, já que a APA é uma Unidade de Conservação de Uso Sustentável;

- Nas áreas urbanas ao longo do médio Sapucaí, destacando-se as cidades de Santa Rita do Sapucaí e Itajubá a recuperação das margens do Rio Sapucaí 
e seus afluentes poderia prever a composição de Parques Urbanos lineares integrando a atividade de conservação com a necessidade de oferecimento de áreas de recreação e lazer.

- Nas áreas rurais a recomposição da mata ciliar deve ser incentivada com programas que a viabilizem e compatibilizem as atividade geradoras de renda para o produtor com a preservação, realizando-se também atividades educativas;

- Atividades de educação ambiental em todos os municípios do Alto e Médio Sapucaí voltadas para a preservação ambiental de espécies de fauna e flora e também de recursos naturais como a água e o solo;

- Incentivo ao desenvolvimento científico com a criação de centros ou grupos de pesquisa em biotecnologias e manejo ambiental, que poderiam ser gerenciados pelas universidades da região em integração com a APA da Serra da Mantiqueira e outras áreas protegidas;

- Promoção de eventos periódicos ao longo do rio que incentivariam a integração social e a educação ambiental.

- Criação de uma "Parkway", como as existentes nos Estados Unidos da América, que podem também ser chamadas Estradas-Parque ou Estradas Cênicas. Esta Estrada Cênica seria a transformação da Rodovia Br 459 em uma estrada com regras de controle ambiental. Nos trechos em que esta coincide com o curso do Rio Sapucaí seriam garantidas a preservação através do incentivo a apreciação da paisagem atribuíndo-se regras de segurança que incluem níveis mais baixos de velocidade, e também regras para a preservação ambiental, colocando a disposição do usuário locais para paradas e apreciação da paisagem e pontos de encontro. 
$47^{\circ}$ $46^{\circ}$ $45^{\circ}$ $44^{\circ}$

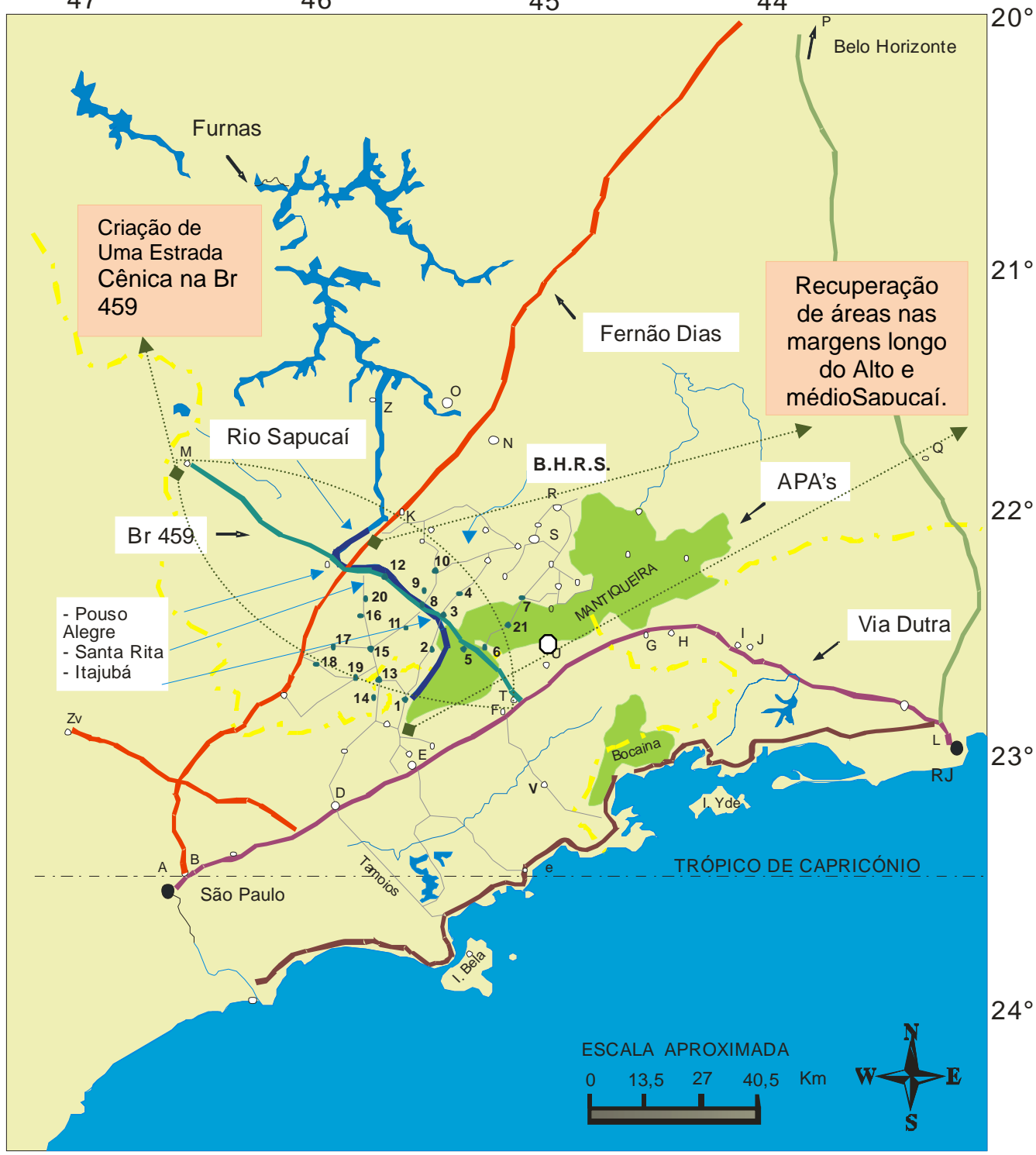

\section{MUNICÍPIOS DO ALTO E MÉDIO} SAPUCAÍ

1 - Campos do Jordão - SP

2 - Piranguçu

3 - Itajubá

4 - Maria da Fé

5 - Wenceslau Brás

6 - Delfim Moreira

7 - Virgínia

8 - Piranguinho

9 - São José do Alegre

10 - Pedralva

11 - Brasópolis

12 - Santa Rita do Sapucaí

13 - São Bento do Sapucaí - SP

14 - Sapucaí Mirim

15 - Paraisópolis

16 - Conceição dos Ouros

17 - Consolação

18 - Córrego do Bom Jesus

19 - Gonçalves

20 - Cachoeira de Minas

21 - Marmelópolis

\section{LEGENDA}

Municípios do Alto e Médio Sapucaí

Outros municípios

$-\operatorname{Br} 459$

— Via Dutra

Br 040

Rodovia Rio-Santos

- Outras rodovias Limites Estaduais

Rio Sapucaí

APA's (Serra da Mantiqueira)

Elaboração: Faria, Helena M

Fonte: Guia Quatro Rodas

\section{OUTROS MUNICÍPIOS}

D - São José dos Campos

H - Rezende

N - Três Corações

S - São Lourenço

E - Taubaté

I - Barra Mansa

O - Varginha

$\mathrm{T}$ - Lorena

F - Guaratinguetá

M - Poços de Caldas

Q - Juíz de Fora

U - Cruzeiro

G - Itatiaia

R - Caxambu

\section{V - Cunha}

- Ações para a conservação ambiental

O - Fortalecimento da Gestão na Apa da Serra da Mantiqueira. áreas urbanas 


\subsection{2 - Cenário de desenvolvimento do Ecoturismo e do turismo cultural no Alto e Médio Sapucaí}

O estudo dos circuitos turísticos da região estudada e sua integração com outros circuitos e regiões apresentados neste trabalho advertem para a necessidade de se realizar melhoria nos aspectos de infra-estrutura para o turismo, incentivo a valorização da cultura local e, posteriormente, a divulgação e manutenção dos circuitos, garantindo que as atividades realizadas não sejam degradadoras do ambiente natural.

Outro ponto importante é a configuração de uma integração dos circuitos turísticos existentes na região, fazendo com que estes sejam complementares e não competitivos. Assim a proposta é que o planejamento ambiental equacione diretrizes que satisfaçam os objetivos do Circuito Turístico Caminhos do Sul de Minas, do Circuito Turístico Terras Altas da Mantiqueira e os integrem às proposta da Rota Estrada Real.

As ações consideradas como mais importantes seriam as seguintes neste cenário:

- Investimento na infra-estrutura para o turismo que seria principalmente a recuperação e manutenção das estradas e vias, a sinalização dos circuitos e a melhoria dos equipamentos urbanos existentes;

- A recuperação de atrativos turísticos do circuito, que poderia ser incentivada por órgãos estaduais e nacionais de incentivo e de preservação do patrimônio artístico e cultural; 
- A criação de parques urbanos e equipamentos de recreação com apoio de profissionais de arquitetura e paisagismo;

- Incentivo à pesquisa sobre a cultura e as condições de vida da população local e a proposição de programas de melhoria. Esta ação requer maior tempo e investimento visto que a estrutura e o incentivo das Universidades da região estão voltados mais para a educação tecnológica;

- A manutenção e incentivos a projetos de turismo ecológicos já existente e principalmente a sua integração com as populações tradicionais que poderiam auxiliar na obtenção de renda e emprego em projetos como estes, melhorando os índices de qualidade de vida, especialmente na região do Alto Sapucaí;

- O resgate de tradições culturais através da pesquisa e da promoção de eventos que revitalizem os mesmos;

- A promoção de eventos periódicos tais como festivais de música, dança e teatro;

- A manutenção da integração com os circuitos e localidades vizinhas já consolidadas tais como o Circuito das Águas e a Cidade de Campos do Jordão, incentivando um intercâmbio de turistas, compatibilizando o calendário de eventos e distribuindo as atividades turística de maneira satisfatória para todos envolvidos. 


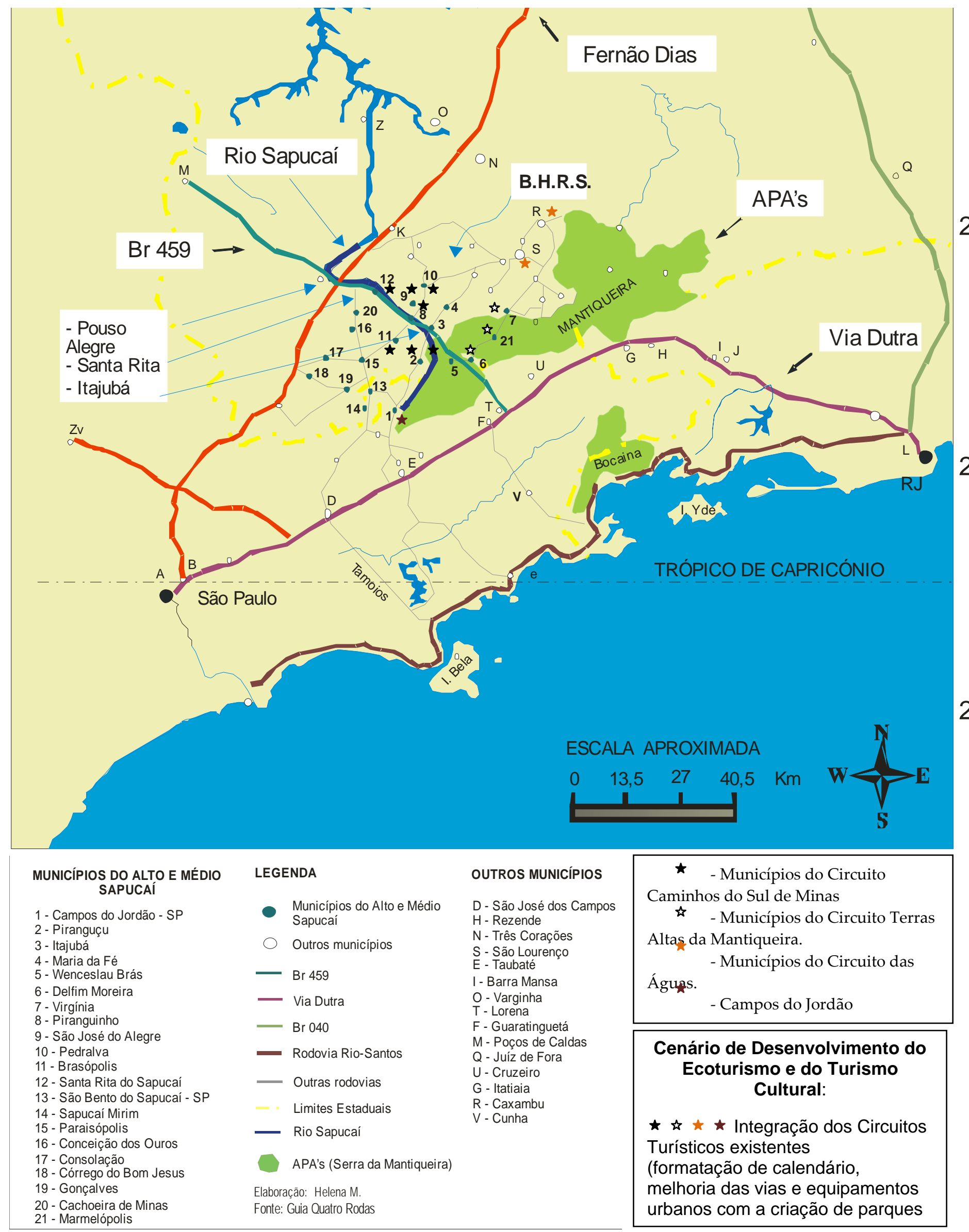




\subsection{3 - Cenário de desenvolvimento de Pólos Tecnológicos}

A tradição regional já consolidou este cenário na região estudada especialmente nas cidades de Itajubá e Santa Rita do Sapucaí. Faz-se necessário ainda uma melhoria da integração entre a produção científica tecnológica, das Universidades e a produção industrial, e destas com a conservação ambiental.

Outro ponto importante é a garantia de que as tecnologias desenvolvidas beneficiarão a maioria da população local, fato que ainda não ocorre, com exceção de algumas experiências isoladas. É necessário se criar atividades que promovam o cooperativismo e o empreendedorismo, melhorando assim a distribuição de renda da população.

Faz-se necessário ainda que o desenvolvimento tecnológico não se desenvolva apenas nas áreas de ciências exatas, como tem sido privilegiado ao longo do tempo na região, mas também o desenvolvimento de biotecnologias com objetivos de sustentabilidade e desenvolvimento de tecnologias voltadas para melhoria da qualidade de vida da população, destacando-se aquelas que garantam a acessibilidade nos centros urbanos e seu aperfeiçoamento estético e paisagístico.

Outro ponto a ser ressaltado se refere à promoção de desenvolvimento econômico e social no Alto Sapucaí, garantindo que o desenvolvimento tecnológico beneficie também esta área que pode ter como prioridade o desenvolvimento de tecnologias ambientalmente corretas.

Ressalvadas estas necessidades as ações propostas seriam:

- A manutenção dos programas existentes de incentivo ao desenvolvimento tecnológico tais como as incubadoras de empresa instaladas em universidades e municípios da região; 
- A reativação da iniciativa Rota Tecnológica 459 (da BR 459) trazendo como objetivo principal a aplicação de tecnologias na própria estrada, incluindo as atividades de preservação ambiental.

- O incentivo aos programas de desenvolvimento de tecnologias voltadas para o cooperativismo, que possam promover a distribuição de renda;

- Incentivo ao desenvolvimento da pesquisa e aplicação de tecnologias ambientais e sustentáveis que revertam em renda para a região, tais como produtos de extração sustentável, produtos de biotecnologia;

- Incentivo às tecnologias voltadas para o saneamento ambiental;

- Realização de parcerias entre universidades, ONGs, empresas, e porque não áreas protegidas onde sejam permitidos a pesquisa e o desenvolvimento de tecnologias, como na APA da Serra da Mantiqueira;

- Investimentos em educação e saúde;

- Incentivo ao intercâmbio nacional e internacional de pesquisadores que pode ser promovido pelas universidades;

- Manutenção e criação de feiras de negócios e de tecnologia. 


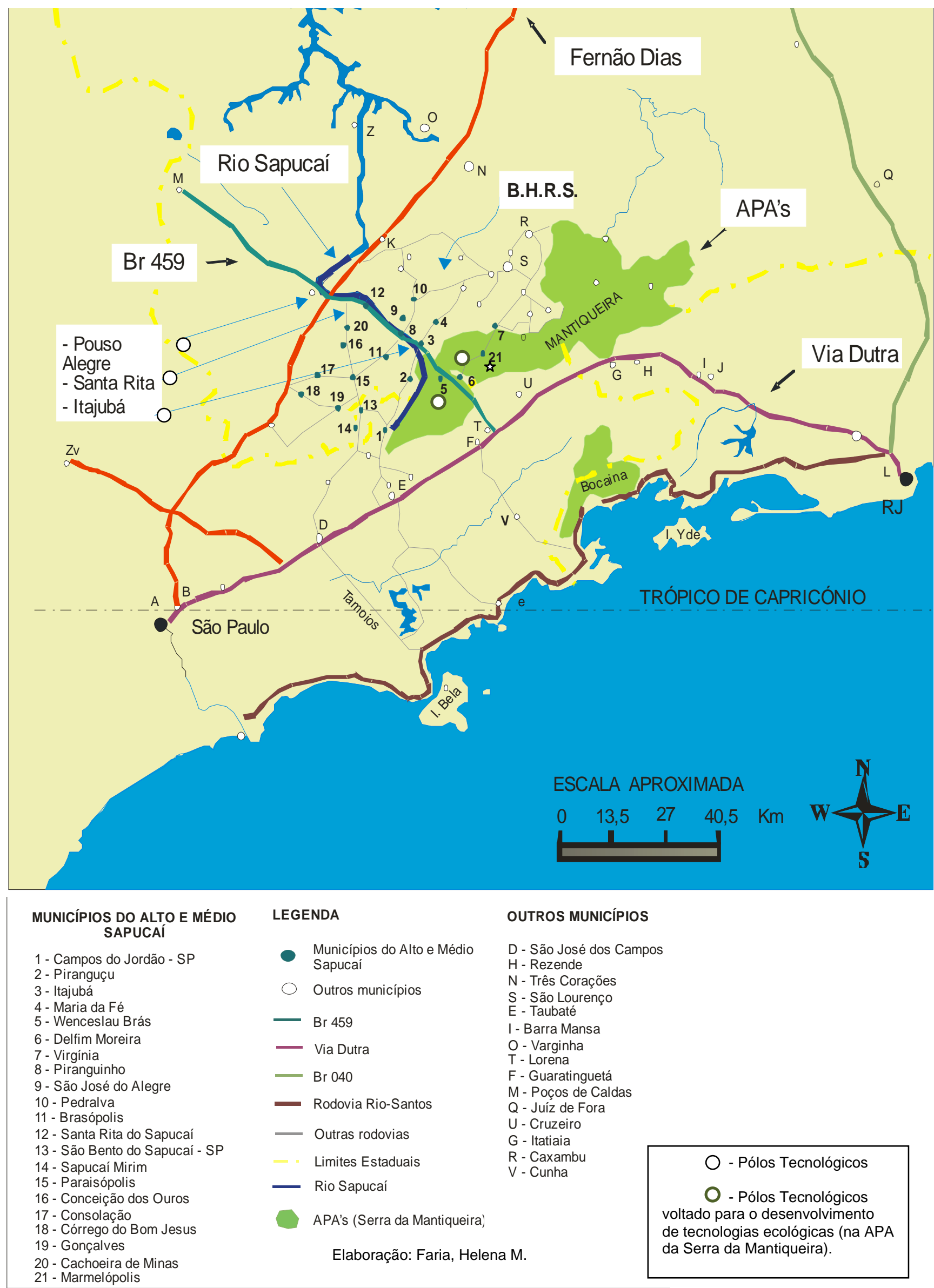

Figura 63: Cenário de desenvolvimento de Pólos Tecnológicos. 


\subsection{4 - Cenário de desenvolvimento sustentável}

Este cenário é um cenário integrador, ou seja, mesmo que a promoção dos cenários anteriores não seja realizada pelas mesmas instituições deve haver um fórum que congregue os envolvidos na conservação ambiental, no desenvolvimento do turismo e das tecnologias sustentáveis para geração de melhoria da qualidade de vida das populações do Alto e Médio Sapucaí. Esta atividade integradora pode ser promovida pelo comitê de Bacia ou por um fórum permanente de discussões que abranja as questões apresentadas nos cenários anteriores.

O Cenário de Desenvolvimento Sustentável tem como subjacente às idéias de conservação ambiental, de desenvolvimento econômico, que pressupõem o desenvolvimento tecnológico e também para a região estudada o desenvolvimento turístico. Se os princípios e ações apresentadas nos cenários anteriores forem minimamente atendidos considera-se que o Cenário de Desenvolvimento Sustentável se consolidará.

Sendo o processo de planejamento um ato contínuo de revisão e recriação, as propostas dos planos executados devem ser periodicamente revistas e analisadas pelas entidades envolvidas. Também a gestão do processo de planejamento é fundamental para seu sucesso. Em virtude de tratar-se de um planejamento ambiental, e, portanto, fundamentalmente público, a questão principal do sucesso dos planos propostos dependerá do envolvimento político da comunidade da região estudada. Sendo assim devem ser incentivadas as ações que permitam o gerenciamento participativo das propostas para a região.

Como um dos desafios bastante discutido neste trabalho foi a melhoria do sistema viário e da integração do alto e médio Sapucaí com os centros urbanos mais 
importantes do país, considera-se que a criação de uma "Parkway", Estrada-Parque ou Estrada Cênica ao longo da Br. 459 parece constituir um projeto integrador do desenvolvimento turístico e tecnológico e da preservação ambiental.

Esta Estrada Cênica que poderia ser chamada de Estrada das Sapucaias, resgatando a importância da espécie nativa que originou o nome do Rio Sapucaí traria regras de segurança que incluiria velocidades mais baixas de trânsito, também regras para a preservação ambiental, e ofereceria ao usuário locais para paradas e apreciação da paisagem, pontos de integração com os circuitos turístico onde poderiam ser instalados centros de informações e convivência.

Entretanto a implantação da Estrada cênica das Sapucaias não deixaria de lado outras ações propostas como o fortalecimento do gerenciamento ambiental da APA da Serra da Mantiqueira, a integração das atividades dos circuitos turísticos Caminhos do Sul de Minas e Terras Altas da Mantiqueira e o incentivo ao desenvolvimento tecnológico. A figura abaixo ilustra as idéias apresentadas para o Cenário de desenvolvimento Sustentável para o Alto e Médio Sapucaí. 


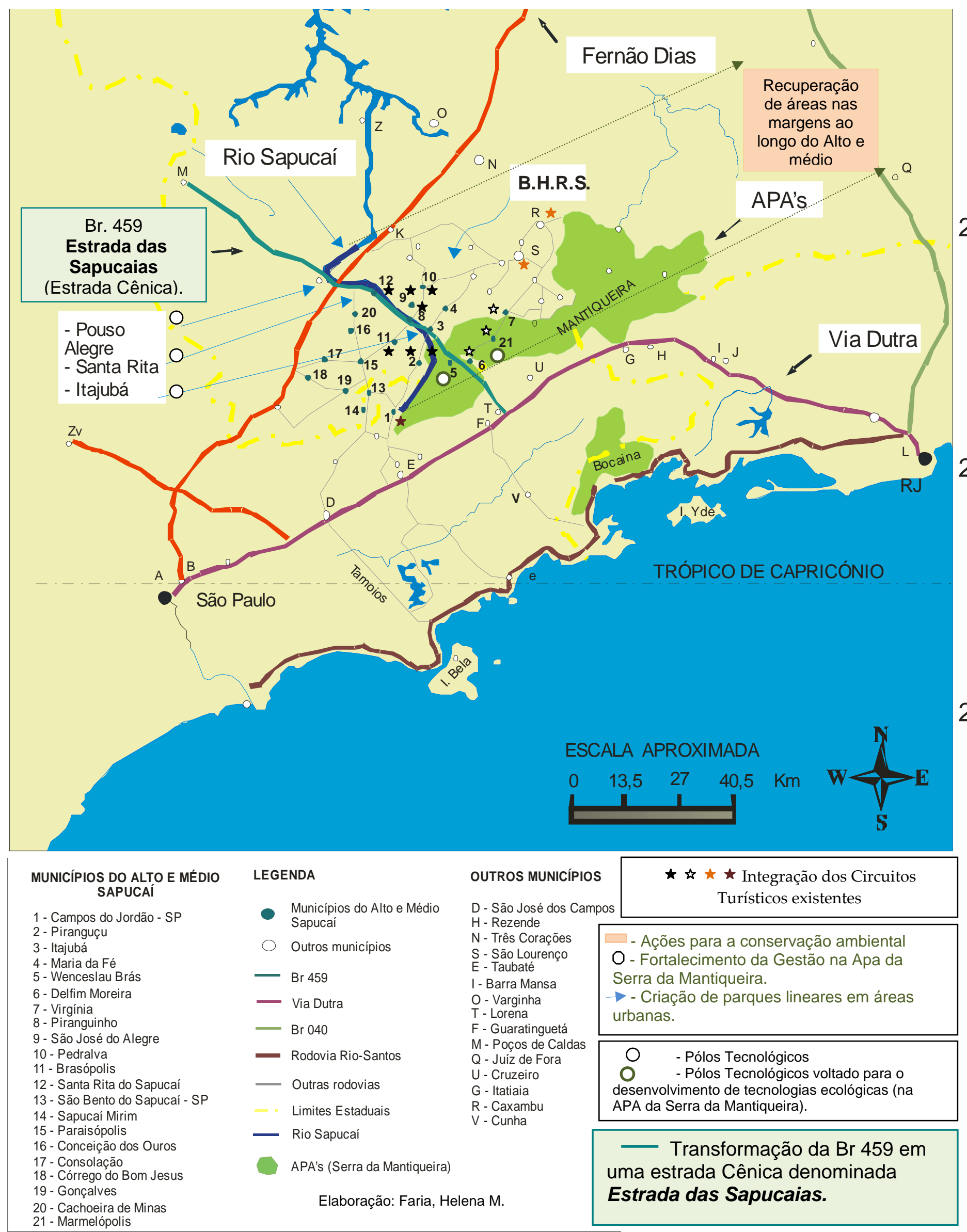

Figura 64: Cenário de Desenvolvimento Sustentável. 
PARTE 4

CONCLUSÃO E BIBLIOGRAFIA 


\section{CONCLUSÃO}

O planejamento ambiental deve representar a síntese dos anseios de uma sociedade na busca da reconstituição do equilíbrio com seu ambiente, mas ainda não existem mecanismos que permitam que esta síntese seja completa. Entretanto, o planejamento ambiental é um mecanismo de transformação e indução de mudanças sociais, capaz de redirecionar as ações de grupos sociais possibilitando a melhoria de sua qua1idade de vida que inclui o equilíbrio ambiental.

O planejamento ambiental deve ser visto como fator indutor de desenvolvimento sustentável. Para tanto os elementos essenciais são a participação comunitária, o entendimento da realidade e a tomada de decisões em conjunto.

Na região estudada observou-se uma extrema carência de planejamento ambiental, ainda que ações isoladas para a obtenção da sustentabilidade estejam presentes. $\mathrm{O}$ entendimento do planejamento ambiental como um instrumento de transformação social através da participação democrática poderá proporcionar a reconstrução deste território de riqueza única. Para tanto faz-se necessário o reconhecimento desta região como estratégica no cenário globalizado, e que a mesma possa encontrar meios de se sustentar frente a um sistema mundial ainda em desequilíbrio, partindo da reorganização do local para o global.

O Alto e Médio Sapucaí podem reinventar a experiência do planejamento para a sustentabilidade e se transformar na região sustentável almejada. Neste sentido, o elemento indutor de sustentabilidade proposto é a "Estrada das Sapucaias", uma estrada cênica que transformará a Rodovia BR 459, mudando as relações de uso desta região, valorizando todo seu potencial turístico, econômico, paisagístico e ambiental. 


\section{REFERÊNCIAS BIBLIOGRÁFICAS}

ALFONSO, Maria José Pastor. El Patrimônio Cultural como Opção Turística IN: Horizontes Antropológicos. Porto Alegre: ano 9, n²0, p.97-115, outubro de 2003.

ALMEIDA, Josimar R. de.et all. Planejamento Ambiental. Rio de Janeiro: Thex Editora, 1999.

ANDRADE, Alexandre Carvalho de. e VIEIRA, Lygia. Crescimento Urbano e Qualidade de Vida em Municípios do Sul de Minas Gerais. In: III Seminário de Pós-Graduação em Geografia da UNESP. UNESP: Rio Claro-SP, Dezembro de 2003.

ANDRADE, Alexandre Carvalho de. e VIEIRA, Lygia. Recursos Paisagísticos e Turismo no Alto Sapucaí. In: III Seminário de Pós-Graduação em Geografia da UNESP. UNESP: Rio Claro-SP, Dezembro de 2003.

ARANTES, Paulo Tadeu Leite. Cidade, Competitividade, Competição e Cooperação estudo de caso de quatro cidades sul mineiras à luz da competitividade, da competição e da cooperação. Tese de Doutorado. São Paulo: FAU/USP, 2001. 340 p.

BERALDO, Ana Maria et al. Sapucaí, o Caminho das Águas. Pouso Alegre/MG. 1996.

BERNARDES, Júlia Adão e FERREIRA, Francisco Pontes de Miranda. Sociedade e

Natureza. In: A Questão Ambiental-Diferentes Abordagens. CUNHA, S B. da E GUERRA, Antônio J T. (ORGs.). Rio de Janeiro: Bertrand Brasil, 2003.

BRITO, Francisco e CAMARA, João B. D. Democratização e Gestão Ambiental: em busca do desenvolvimento sustentável. Petrópolis-RJ: Vozes, 1998.

CASTRO, José Flavio Moraes e ABREU, João Francisco. Mapeamento das potencialidades espaciais do Sul de Minas e entorno no ano de 1999. In: Caderno de Geografia. Volume 14, n²2, PUC-MINAS: Belo Horizonte-MG, junho de 2004.

COSTA, Joana P. Luiz da Costa. Cartilha História da ocupação da Serra da Mantiqueira. In: "Projeto para o Fortalecimento da Gestão participativa da APA da Serra da Mantiqueira". Brasília-DF: MMA/FNMA 057/2003. (CD ROOM).

COSTA, José Pedro de Oliveira. Matutu, Pedra do Papagaio e Aiuruoca. Tese de Doutorado FAU/USP, 1987.

CROWE, Normam "Nature and the idea of a man made world". The MIT Press Cambridge: London, England, 1995.

DIEGUES, Antônio Carlos Sant'ana. O Mito moderno da natureza intocada. $2^{\mathrm{a}}$ ed. Hucitec: São Paulo, 1998. 
FARIA, Izabel Mendonça. Efervescência e Decadência de Atividades Agrícolas: a questão ambiental como causa da decadência e como saída para a retomada do desenvolvimento. In: Anais do II Encontro da ANPPAS (Associação Nacional de PósGradução e Pesquisa em Ambiente e Sociedade) Indaiatuba-SP, maio de 2004. (CD ROOM).

FARIA, Izabel Mendonça. Vozes e Imagens do Rio São Francisco: um estudo sobre populações tradicionais e problemas ambientais. Dissertação de Mestrado. Centro de Educação e Ciências Humanas/Programa de Pós-Graduação em Ciências Sociais. Universidade Federal de São Carlos (UFscar). São Carlos, 2002.

FARIA, Marcelo Oliveira de. O Mundo Globalizado e a questão Ambiental. In: Meio Ambiente: Educação e Ecoturismo. NEIMAN, Zysman (org.). Barueri-SP, Editora Manole, 2002.

FONSECA, Maria Lucinda. Patrimônio, Turismo e Desenvolvimento Local. In: RODRIGUES, Adyr Balastreri (Org). Turismo Rural. São Paulo: Editora Contexto, 2001. Págs. 47 a 68.

FRANCO, Maria Assunção Ribeiro. Desenho Ambiental: uma Introdução à Arquitetura da Paisagem, com o Paradigma Ecológico. Annablume/Fapesp: São Paulo, 1997.

FRANCO, Maria de Assunção Ribeiro. Planejamento Ambiental para a Cidade Sustentável. São Paulo: Annablume: EDIFURB, 2001.

GERTTARDT, Cleyton Henrique e ALMEIDA, Jalcione. A dialética dos Campos Sociais na interpretação da problemática ambiental: uma análise crítica de diferentes leituras sobre os problemas ambientais. REVISTA AMBIENTE \& SOCIEDADE, Vol VIII $\mathrm{n}^{\circ} 2$, julho/dezembro de 2005.

GOITIA, Fernando Chueca. Breve história o Urbanismo. Lisboa-Portugal: Editora Presença, 1992. (Introdução- Lição 1).

GUIMARÃES, Armelim. História de Itajubá. Belo Horizonte: Instituto Mineiro de Pesquisa em Historia e Geografia. S/D.

GUIMARÃES, Armelim. Itajubá e sua História. Belo Horizonte: Itajubá: 1998.

HOUGH, Michael. Naturaleza y Ciudade. Barcelona: Editorial Gustavo Fili S.A., 1998.

IBAMA/FNMA. Programa Gestão Participativa, APA da Serra da Mantiqueira. Projeto "Fortalecimento da Gestão Participativa na APA da Serra da Mantiqueira" (CD ROOM). 2003.

IBGE - Departamento de População. Indicadores Sociais. - Síntese de indicadores sociais 2002 IBGE, Rio de Janeiro, 2003, 383 p. — CD-ROM, ISBN 85-240-3165-4. 
KATHOUNI, Saide. Introdução a algumas considerações sobre Paisagem e Ambiente. In: Revista do Programa de Pós-Graduação em Arquitetura e Urbanismo da FAU-USP: número 19. São Paulo, 2006.

LAYARGUES, P.P. A cortina de fumaça: o discurso empresarial verde e a ideologia da racionalidade econômica, 1998.

LORENZI, Harry. Árvores Brasileiras: manual de identificação e cultivo de plantas arbóreas do Brasil. 4ª Ed. Instituto Plantarum: Nova Odessa-SP, 2002.

MCHARG, Ian L. Design with nature. New York: Natural History Press, 1969.

MAGNOLI, Miranda M. E. M. Paisagem: pesquisa sobre o desenho do espaço. In: PAISAGEM E AMBIENTE — Ensaios. FAU/USP: São Paulo, 1986.

ODUM, Eugene, P. Ecologia, Rio de Janeiro: Editora Guanabara, 434 p.,1985.

OSEKI, Jorge Hajime e PELLEGRINO, Paulo Renato Mesquita. Paisagem Sociedade e Ambiente. In: PHILLIPI Jr, A. ROMÉRO, M. A. e BRUNA, G. C. (Orgs) Curso de Gestão Ambiental. Manole: Barueri-SP, 2004.

PEREIRA, Magali R. B. Preservação do Meio Ambiente na Bacia Hidrográfica do Rio Sapucaí. Lorena-SP: UNISAL.

PORTER, Michael e VAN DER LINDE, C. Toward a new conception of teh environment Competitiveness Relationship. In: JOURNAL OF ECONOMICS PERSPECTIVES. Boston, v. 9, nº 4, p. 97-118, fall 1995.

PRADO, Rosane M. As Espécies Exóticas somos nós: reflexão a propósito do turismo ecológico na Ilha Grande. IN: Horizontes Antropológicos. Porto Alegre: ano 9, $\mathrm{n}^{\circ} 20$, outubro de 2003.

PRUDENTE, Henrique Alckmin. Turismo Cultural: as culturas subalternas e o turismo emancipador em Cunha. Taubaté-SP: Cabral Editora e Livraria Universitária, 2005.

RATTNER, Henrique: "Sustentabilidade - uma visão Humanista". Revista Ambiente e Sociedade. Núcleo de estudos e pesquisas ambientais da UNICAMP: Ano II, $\mathrm{n}^{\circ} 5-2^{\circ}$ semestre de 1999.

REIS FILHO, Nestor Goulart e MEDRANO, Ricardo Hernán. Urbanização e Urbanismo no Brasil. Notas de aulas. In: REVISTA DE ESTUDOS SOBRE A URBANIZAÇÃO, ARQUITETURA E PRESERVAÇÃO. Série Urbanização e Urbanismo. $\mathrm{n}^{\circ}$ 19. FAU USP. São Paulo, maio-junho de 2007. 
RODRIGUES, André Figueiredo. Os sertões Proibidos da Mantiqueira: Desbravamento, ocupação da terra e as observações do governador Dom Rodrigo José de Meneses. In: Revista Brasileira de História São Paulo: ANPUH (Associação Nacional de História), vol. 23, $n^{\circ}$ 46, julho-dezembro, 2003.

RODRIGUES, Arlete Moysés. "A Utopia da Sociedade Sustentável" In: Revista Ambiente \& Sociedade, Núcleo de estudos e pesquisas ambientais da UNICAMP: Ano I, $n^{\circ} 2-1^{\circ}$ semestre de 1998.

SAMPAIO, Teodoro. Viagem à Serra da Mantiqueira: Campos do Jordão e São Francisco dos Campos. São Paulo: Editora Brasiliense, 1978.

SANTOS, Márcio. Estradas Reais: introdução ao estudo dos caminhos do ouro e do diamante no Brasil. Belo Horizonte: Editora Estrada Real, 2001.

SANTOS, Márcio. A rota do ouro e dos diamantes. IN: Revista Nossa História. São Paulo: Editora Vera Cruz, ano 3, n 30, abril de 2006.

SANTOS, Milton. A natureza do Espaço: técnica e tempo, razão e emoção. São Paulo: $3^{a}$ ed. Hucitec, 1999.

SANTOS, Milton. A Urbanização Brasileira. São Paulo: Editora Hucitec, 1994.

SANTOS, Rosely Ferreira dos. Planejamento Ambiental: teoria e prática. São Paulo: Oficina de Textos, 2004.

SPIRN, Anne Whiston. O jardim de Granito: a natureza no desenho da cidade. São Paulo: EDUSP, 1.995.

VITAL, Giovanna Teixeira Damis. Desenho Ambiental em Uberlândia: o caso do Córrego Lagoinha. Dissertação de Mestrado. FAU/USP: São Paulo, 2003.

www.caxambu.mg.gov.br - Site oficial da Prefeitura Municipal de Caxambu.

www.conexaoitajuba.hpg.ig.com.br - Site oficial do COMTUR (Conselho Municipal de Turismo de Itajubá) acessado em 25 de setembro de 2004.

www.cunhatur.com.br - Site da Associação dos Empresários do Setor de Turismo de Cunha.

www.estradareal.org.br - Site oficial do Instituto Estrada Real.

www.gentedefibra.com.br - Site da Oficina Gente de Fibra em Maria da Fé.

www.ibge.gov.br/cidades - Site oficial do Instituto Brasileiro de Geografia e Estatística. 
www.itajubá.mg.gov.br - Site oficial da Prefeitura Municipal de Itajubá acessado em 26 e 27 de setembro de 2004.

www.mariadafe.mg.gov.br - Site oficial da Prefeitura Municipal de Maria da Fé.

www.mineiros-uai.com.br - acessado em 26 e 27 de setembro de 2004.

www.portitajuba.com.br - acessado em 20 de setembro de 2004.

www.prefeiturapiranguinho.com.br - Site oficial da Prefeitura Municipal de Piranguinho.

www.saolourenco.mg.gov.br. - Site oficial da Prefeitura Municipal de São Lourenço.

www.saolourençoonline.com.br.

www2.ibge.gov.br - Site Cidade do Instituto Brasileiro de Geografia e Estatística acessado em 20 de setembro de 2004.

http://www.igam.mg.gov.br/index.php?option=com_content\&task=view\&id=150\&ltemid=140 (2007-09-14, site IGAM).

http://www.estaçõesferroviaria.com.br/rmv_sapucai. 


\section{BIBLIOGRÁFIA CONSULTADA}

AFONSO, Cintia Maria. Uso e ocupação do solo na zona costeira do estado de São Paulo, uma análise ambiental. Abbablume/Fapesp, 1999.

AUN, Miguel. Minas Gerais: cores e sentimentos. Escrituras Editora: São Paulo, 2003.

CASTROGIOVANNI, Antônio Carlos (Org.). Turismo Urbano. Contexto: São Paulo, 2001.

CUNHA, Sandra Baptista. e GUERRA, Antônio José Teixeira. (orgs.) Avaliação e Perícia Ambiental. Bertrand Brasil: Rio de Janeiro, 2000.

CLARK, Robin e KING, Janet. O Atlas da Água. Publifolha: São Paulo, 2005.

DEL RIO, Vicente e OLIVEIRA, Lívia. Percepção Ambiental: a experiência brasileira. Editora da UFScar/ Studio Nobel: São Carlos-SP, 1996.

FERREIRA, José Bento. O Desenho Ambiental aplicado a Sistemas Viários: a utilização de Zonas Ambientais de uso compartilhado (ZAUCs) para a solução de conflitos viárioambientais. Tese de Doutorado. FAU/USP: São Paulo, 2002.

GUERRA, Antônio José Teixeira e CUNHA, Sandra B. da. (Orgs.) Impactos Ambientais Urbanos no Brasil. Bertrand Brasil: Rio de Janeiro, 2001.

HOLANDA, Sérgio Buarque de. Raízes do Brasil. 21ª edição. José Olympio: São Paulo, 1989.

MARTINS Jr. Uma cidade Ecologicamente Correta. AB: Goiânia, 1996.

MUNFORD, Lewis. A cidade na História: sua origens, transformações e perspectivas. $4^{\mathrm{a}} \mathrm{Ed}$. Martins Fontes:São Paulo, 1998.

PELLEGRINO, Paulo Renato Mesquita. Fragmentos de Paisagens. In: Paisagem e Ambiente: ensaios. N 9. FAU/USP: São Paulo, dezembro de 1996.

RODRIGUES, Adyr Balastreri (Org). Turismo Rural. Contexto: São Paulo, 2001.

RIBEIRO, Helena e VARGAS, Heliana Comin. Novos Instrumentos de Gestão Ambiental Urbana. Edusp: São Paulo, 2001.

SANTOS, Milton. A natureza do Espaço: técnica e tempo. Razão e emoção. $3^{a}$ Ed. Hucitec: São Paulo, 1999.

SERRA, Geraldo G. Pesquisa em Arquitetura e Urbanismo: guia prático para os pesquisadores em pós-graduação. Edusp/Mandarim: São Paulo, 2006.

SOLANO, Carlos. Feng Shi - Kan Yu, Arquitetura Ambiental Chinesa. Pensamento: São Paulo, 2000. 